\title{
PÉ E FÉ NA CAMINHADA: povo em movimento na produção do espaço urbano paulistano
}

Claudia de Andrade Silva Duarte Orientadora: Prof ${ }^{a}$. Dra ${ }^{\mathrm{a}}$. Camila Loffredo D'Ottaviano

FACULDADE DE ARQUITETURA E URBANISMO UNIVERSIDADE DE SÃO PAULO PROGRAMA DE PÓS-GRADUAÇÃO 
Claudia de Andrade Silva Duarte

\section{PÉ E FÉ NA CAMINHADA: \\ povo em movimento na produção \\ do espaço urbano paulistano}

Dissertação apresentada ao Programa de Pós-Graduação

da Faculdade de Arquitetura e Urbanismo da Universidade

de São Paulo como parte dos requisitos para obtenção do título

de Mestra em Arquitetura e Urbanismo.

Área de Concentração: Habitat

Linha de Pesquisa: Participação social e políticas públicas

a produção e gestão do habitat

Orientadora: Profa. Dra ${ }^{\text {a }}$ Camila Loffredo D’Ottaviano

Esta pesquisa contou com apoio e bolsa da CAPES -

Coordenação de Aperfeiçoamento de Pessoal de nível Superior 
AUTORIZO A REPRODUÇÃO E DIVULGAÇÃO TOTAL

OU PARCIAL DESTE TRABALHO, POR QUALQUER MEIO

CONVENCIONAL OU ELETRÔNICO, PARA FINS DE ESTUDO

E PESQUISA, DESDE QUE CITADA A FONTE.

email: claudiaas352@gmail.com

\section{PÉ E FÉ NA CAMINHADA:}

povo em movimento na produção

do espaço urbano paulistano

Exemplar revisado e alterado em relação à versão apresentada para arguição da banca, realizada em 04 de outubro de 2021, sob responsabilidade da autora e anuência da orientadora.

São Paulo, 03 de dezembro de $2 \mathrm{O} 21$

Faculdade de Arquitetura e Urbanismo da Universidade de São Paulo

\begin{tabular}{|c|}
\hline $\begin{array}{l}\text { Duarte, Claudia de Andrade Silva } \\
\text { Pé e fé na caminhada: povo em movimento na produção do } \\
\text { espaco urbano paulistano / Claudia de Andrade Siliaa Duarte; } \\
\text { orientadora Maria Camila Loffredo D'ottaviano. - São Paulo, } \\
\text { 2021. } \\
\text { 306p. }\end{array}$ \\
\hline $\begin{array}{l}\text { Dissertação (Mestrado) - Faculdade de Arquitetura e } \\
\text { Urbanismo da Universidade de São Paulo. Area de } \\
\text { concentraçăo: Habitat. }\end{array}$ \\
\hline $\begin{array}{l}\text { 1. Ocupacãa Urbana. 2. Periferias. 3. Produção Social do } \\
\text { Espaço. 4. Luta Social. II. D'oftaviano, Maria Camila } \\
\text { Lofffredo, orient. II. Título. }\end{array}$ \\
\hline
\end{tabular}

Elaborada eletronicamente através do formulario disponivel em: ‘htip://www.fau.uss.bbrfichaccatalograficas

Nota sobre o título: "Pé e fé na caminhada" é o título de um longa-metragem produzido pela Verbo Filmes (1987), que aborda a luta social travada pelas Comunidades Eclesiais de Base. Aproveito para fazer memória a Dom Paulo Evaristo Arns, que completa seu centenário este ano, cuja trajetória foi de ir ao encontro das periferias, incentivando a criação das CEBs paulistanas e segue sendo um grande exemplo de Igreja em saída.

Foto da capa: entardecer no Jardim da União e a "biovaleta" (2019). Acervo da autora. 
Num país como o Brasil, manter a esperança viva é em si um ato revolucionário.

Paulo Freire

O mundo não é formado apenas pelo que já existe,

mas também pelo que pode efetivamente existir.

Milton Santos

Centenário de Paulo Freire, cuja vida e produção são constantes fontes de inspiração para minha própria reinvenção ao buscar a reinvenção do mundo. Sigo esperançando.

E, 20 anos do falecimento de Milton Santos, cujo legado me ajuda a fazer uma leitura crítica das cidades brasileiras.

Neste trabalho, que aborda o contexto da ditadura militar, é imprescindivel citar essas duas potências brasileiras, que atravessaram esse período autoritário com resistência, foram exilados e nunca desistiram da construção de outros mundos possíveis.

Dedico essa dissertação a tantas e tantos que são movidos pelo pé e fé na caminhada, em especial, às moradoras da ocupação Jardim da União.

E, também, para aqueles que partiram ao longo da escrita dessa dissertaçãontio toninho, vó amada e didi. Para sempre estarão em minha memória. 


\section{AGRADECIMENTOS}

A melhor maneira de finalizar esse ciclo é agradecendo a todos aqueles que me acompanharam, seja mais de perto ou de longe, e foram fundamentais para que eu conseguisse chegar até aqui. Ao longo desse percurso, constituí uma verdadeira rede de apoio, amparo, incentivo e ensinamentos, por isso agradeço:

À Camila D'Ottaviano, por ter sido, a um só tempo, orientadora e amiga. Sobretudo em tempos pandêmicos, por ter me ajudado a superar os desafios impostos por esse contexto (sua alegria de viver é contagiante!). Camila me acolheu de braços bem abertos, generosa como sempre, quando entrei na até então desconhecida FAU-USP. Agradeço pela total liberdade permitida para elaboração dessa pesquisa e incentivo para que eu sempre me colocasse nela. A sua orientação foi um verdadeiro ato de amor, que sorte a minha ser orientada por alguém que pensa e age freireanamente.

O apoio da CAPES (Coordenação de Aperfeiçoamento Pessoal de Nível Superior), na modalidade bolsa de mestrado, de março de 2019 até sua conclusão. Aproveito para reforçar a necessidade de lutarmos pelas políticas públicas, já que, como fiz parte do ProUni e do Ciência sem Fronteiras, sou fruto delas.

Às moradoras do Jardim da União, por terem aberto não somente as portas das suas casas, mas também os corações. Por terem me acolhido com tanto carinho e paciência para compartilhar comigo suas memórias e cotidiano, por permitirem conhecer suas histórias e experiências na luta diária pelo (re) existir na cidade. Eu confio que as práticas de vocês carregam potências transformadoras para a real democratização das cidades. Sem vocês, essa pesquisa não existiria.

Ao Paulo Emílio, que, desde a graduação, tem grande peso nos percursos acadêmicos que sigo. Abriu meus olhos para um universo ate então desconhecido e fez a ponte entre mim e a Camila (melhor orientadora!). E, junto com a Luciana Lago, fez parte da banca de qualificação. Esse momento foi um divisor de águas que alterou o rumo dessa pesquisa. Agradeço também por ter feito parte da banca final, por trazer ricas reflexões e pela leitura tão atenta e cuidadosa.

A Lizete Rubano, por ter me encorajado a realizar esse mestrado na FAU-USP, para que eu me permitisse viver esse novo universo. Sem a sua condução e encorajamento, eu não teria chegado até aqui. Você sempre será uma fonte de inspiração para mim ao pensar em outros mundos possíveis.

Aos professores Caio Santo Amore e Karina Leitão, por permitirem que fizesse parte do CPPATHIS, bem como pela elaboração e condução desse curso. Nesse período, me aproximei mais do Caio, que sempre admirei a distância. Agradeço por me ajudar a organizar a estrutura da dissertação, pela boa conversa de sempre e pelo acolhimento das minhas dúvidas e angústias.

Esse curso foi, sem dúvida, outro ponto de inflexão, pois permitiu a um só tempo conhecer a ocupação Jardim da União e tantas pessoas, que hoje posso chamar de amigas. Para enfrentar os percalços da pós-graduação, eu, Ba, Ca, Flavinha, $\mathrm{Ma}$, Nama e Nat formamos um grupo. Com o passar do tempo, percebemos que ali nos ajudávamos diariamente nas questões impostas pela vida, por isso agradeço ao "clube do bordado". Sem vocês esse percurso teria sido muito solitário.

O CPPATHIS proporcionou também me tornar mais próxima ainda de duas queridas mackenzistas: Carol e Helô, agradeço tanto a vocês por toda preocupação, viagens na van e ótimas risadas. Dos presentes do CPPATHIS, agradeço também à La- 
rissa Viana e ao Gabriel Cabral, queridos Lari e Gabs, por tamanha generosidade em sempre me ajudar e por serem exemplos de pesquisadores comprometidos. Agradeço à Lari também por ter feito parte da banca final e pelo seu rico trabalho ter sido umas das principais referências dessa pesquisa.

De forma especial, agradeço à Marília, pela mão na massa na reta final desse trabalho. Com todo seu talento trouxe vida e forma para pesquisa, com a impecável diagramação, produção e tratamento de todas as imagens. Ma, como não me canso de repetir, sem você essa pesquisa não teria ficado tão bem organizada e ilustrada. Agradeço também todo apoio psicológico nos últimos meses através da troca de mensagens diárias. Palavras nunca serão suficientes para agradecer tudo que fez e faz por mim.

À Nama, por ao longo desse processo sempre estar disposta a me ouvir nas inúmeras crises que enfrentei. Por todo acolhimento, sempre com coração aberto e escuta ativa, por toda a sensibilidade, pela companhia nas idas ao Jardim da União, por me ajudar a construir reflexões a partir do que vimos e vivemos juntas, por ler e reler textos, além de toda troca cotidiana das contrariedades da vida.

A oportunidade de fazer parte do movimento Economia de Francisco, que foi outra inflexão para os rumos da pesquisa, já que me proporcionou inúmeras reflexões e embasamento nos discursos e práticas do Papa Francisco. Agradeço por Bergoglio ser o bispo de Roma em um momento tão obscuro como o que estamos enfrentando no país e no mundo. O Papa Francisco é um verdadeiro acalento para mim.

Ao Klaus Raupp (e sua linda família), verdadeiro amigo-irmão, que entrou tão recentemente em minha vida, mas com tamanha intensidade, reciprocidade e coincidências, que eu posso dizer que essa amizade já fincou raízes. Agradeço pelas reflexões e por me ajudar a acreditar em mim mesma, bem como por ser como és, tão verdadeiro e generoso, com sede de justiça.
Ao Peterson Prates, por me ajudar na construção das ideias, ter concedido entrevista essencial para a pesquisa e ser um exemplo de cristão em saída. Esse trabalho tem muito da sua militância nas comunidades eclesiais e do seu trabalho no chão das periferias paulistanas.

Às amigas de longa data, que estão comigo nas mais diversas fases da minha vida, me apoiando, incentivando e compreendendo minhas ausências. Ju e Jaque, amigas-parceiras de todas as horas, nossas vidas já mudaram tanto e cá estamos, somando mais de treze anos de amizade. Vocês me lembram sempre meu ponto de partida e me ajudam a enxergar a leveza da vida. Às para sempre amigas do liceu, Nah, Ju, Lah e Rafa, e ao Matheus (querido Borbs) por todo incentivo dado, pelas alegrias compartilhadas, por estarem sempre ao meu lado e serem referências para mim, cada um com um jeito tão particular de ser e de ler o mundo. Às amigas que o Mackenzie me trouxe, Aninha e Mari, por serem tão cuidadosas, pacientes e verdadeiras. Aprendo demais com vocês duas. E à Luisa, amiga que o intercâmbio me trouxe e, mesmo de longe, se faz presente em minha vida. Nossos encontros são sempre especiais.

Aos casais amigos Marcinha e Ricardo, Inês e João, Rose e Melone e Jô e Size (e suas famílias), que me acompanham há tanto tempo, e sempre se preocupam com meu bem estar, estando ao meu lado em cada novo ciclo e vibrando a cada conquista. Ao Gustavo que, de colega de trabalho, tornou-se um amigo para toda a vida. Agradeço toda a paciência e disposição em sempre me ajudar nas mais diversas situações, como sempre falo: não à toa é meu padrinho. E ao seu pai, Thiago Richter, que me ensina a cada dia ser uma profissional melhor, por ter me apoiado e compreendido as minhas decisões. E, agora, no finalzinho do mestrado, ter valorizado tanto esse meu percurso acadêmico. Junto ao André Buelau, me deram oportunidade de estágio e primeiro emprego na RB, onde cresci como nunca, e como sempre falo, foi minha segunda graduação.

Aos meus sogros, Didi e Lucas, que são verdadeiros pais para mim. Agradeço o acolhimento caloroso de sempre, pelo incen- 
tivo e pela paciência nas minhas ausências. Além de todos os mimos em forma de alimento, que tornaram esse percurso mais leve e feliz. Agradeço também a linda festa de encerramento desse ciclo que organizaram, juntamente com minha família e meus queridos: Ana, Ângelo, Carolzinha, Tha, Wesley, Kaka, Edu, Duda, Do e Carol. Agradeço a todos o carinho (e as cartinhas!), esse dia ficará para sempre em minha memória.

De forma especial, à minha sogra, por sempre me ensinar tanto com toda sabedoria que carrega. Nossos papos são verdadeiros recarregar de energia. Agradeço também por ter participado da banca final, ter se empolgado tanto e me ajudado a ver tudo com bons olhos. Levarei comigo a frase que me disse: 0 processo que transforma e não a conquista.

À minha cunhada Natalia e sua família, tia Selma e Nessinha, pelo apoio de sempre e por estarem comigo nas mais diversas fases da vida. Agradeço aos pequenos, Marco Antônio, Gueguel e Matheus, por terem me alertado sobre o "relógio da vida" e por me mostrarem outros sentidos de viver, nunca antes experienciados. Ao primo-irmão $\mathrm{Di}$, a quem tenho imenso carinho e sei o quanto torce e ora pela minha felicidade. Nossa troca de mensagens me fortaleceu durante essa caminhada. Ao Edu, também primo-irmão, por toda boa risada, companheirismo e sempre compartilhamos do copo aos momentos únicos. Aos padrinhos, Valdelice e Antônio, por todo carinho preocupação. E à Gegê, afilhada querida, que entrou na minha vida no final dessa jornada, mas já mostrando que veio para ficar, assim como sua linda família: comadre Rosana, Maria Paula e Cláudio.

À minha família, por toda base e amor. Aos meus irmãos, Thiago e Thais, com os quais aprendi o sentido do compartilhamento, do dividir espaço, sonhos, alegrias e tristezas. Agradeço a parceria de sempre, o cuidado e a preocupação. Aos meus pais, José Cláudio e Maria José, pela luta diária e por serem meus principais exemplos de vida. Essa pesquisa diz muito sobre a trajetória árdua de vida que vocês atravessaram. Quando barra aperta é em vocês dois que eu penso e me inspiro. Agra- deço por toda a liberdade em me permitir "voar", incentivar meus sonhos e estudos, ainda que em condições nada favoráveis para nossa classe de origem.

Ao meu companheiro de vida, Lucas, a parceria é o que define nossa relação. Tanto nos aconteceu ao longo da escrita desse mestrado, da troca de sobrenomes à mudança de cidade. Agradeço por toda paciência na minha ausência, por cuidar tão bem de mim e da nossa casa. Por se esforçar tanto para compreender o meu mundo, minhas inquietações e angústias, sempre me escutando e incentivando com tanto carinho. Por ler incansavelmente tudo que escrevo (ainda que prefira os números), por acreditar tanto em mim, quando eu mesma estou desacreditada. Agradeço pelo cotidiano compartilhado, pelo (auto) conhecer diário, como também comungar comigo a aspiração de outros mundos possíveis. Você torna meu dia-a-dia mais leve e alegre, com esse jeito único de viver a vida.

Como essa pesquisa diz muito sobre fé, agradeço a Deus por ter me sustentado até aqui e por todos os sinais ao longo do percurso. Agradeço a São Francisco e Santa Clara de Assis, cujas vidas são constantes fontes de inspiração para mim. 


\section{PÉ E FÉ NA CAMINHADA:}

povo em movimento na produção

do espaço urbano paulistano

\section{FOOT AND FAITH IN THE JOURNEY:}

people on the move in the production

of São Paulo urban space

\section{RESUMO}

Esta dissertação propõe uma análise da política presente nas práticas cotidianas populares, que partem do pé no chão das suas realidades e da fé em outros mundos possíveis. Aborda a relação entre a luta social daqueles que reivindicam o direito à cidade e a produção do espaço urbano. Busca compreender como tais práticas produzem espaços urbanos e quais os limites e potências para a real democratização das cidades. Tem como argumento central a defesa da existência de uma relação dialética entre cidade produz ocupação e ocupação produz cidade. Dizer que a cidade produz ocupação significa reconhecer que está inserida dentro do regime de produção capitalista do espaço, o que resulta em limites. Ao mesmo tempo, parte do entendimento de que a ocupação produz cidade, no sentido de reconhecê-la como uma forma de produção social do espaço urbano, não somente pela necessidade do morar, mas também como resistência a um contexto sociopolítico econômico que é por natureza desigual e excludente. Dai advém a sua potência transformadora. Parte-se da recuperação histórica da atuação das Comunidades Eclesiais de Base nas periferias paulistanas e do trabalho de campo realizado na ocupação urbana Jardim da União, no extremo sul da cidade de São Paulo. Abordar esses dois pontos permitiu refletir sobre permanências e deslocamentos ao longo das últimas décadas, como forma de contribuir para a compreensão sobre como as periferias são significadas e figuradas a depender do contexto, e romper com a visão dicotômica das diversas formas de produção do espaço urbano. Ao estudar o tema da política, a violência se interpôs como uma temática, uma vez que as trajetórias estudadas são atravessadas e marcadas por diversas modalidades de violência, de estigmas e de preconceitos.

Palavras-chave: 1. ocupação urbana 2. periferias 3. produção social do espaço 4. luta social 5. Comunidade Eclesial de Base.

\section{ABSTRACT}

This research proposes an analysis of the politics present in everyday practices, starting from the foot on the ground of their realities and from the faith in other possible worlds. It addresses the relationship between the social struggle of those who claim the right to the city and the production of urban space. It seeks to understand how such practices produce urban spaces and what are the limits and strengths for the real democratization of cities. Its central argument is the defense of the existence of a dialectica relationship between the ideas of the city produces occupation and occupation produces the city. Saying that the city produces occupation means recognizing that it is inserted within the capitalist regime of production of space, which results in limits. At the same time, it starts from the acknowledgment that occupation produces the city, in the sense of recognizing it as a form of socia production of urban space, not only as result of the need to live, but also as a resistance to a sociopolitical and economic context that is by nature unequal and excluding. That's where its transforming power comes from. It starts from the historical recovery of the operation of the Grassroots Ecclesial Community (Comunidades Eclesiais de Base) in the outskirts of São Paulo and from the field work carried out in the urban occupation of Jardim da União, in the extreme south of the city of São Paulo. Addressing these two ideas allowed the reflection about continuity and displacements over the past decades, as a way to contribute to the understanding of how the outskirts are represented and described depending on the context, and to breakout the dichotomous view of the various forms of production of urban space. When studying the politics, violence interposed itself as a theme, since the studied trajectories are crossed and marked by different forms of violence, stigmas and prejudices.

Keywords: 1. urban occupation 2. outskirts 3. social production of space 4. social struggle 5. Grassroots Ecclesial Community. 


\section{SUMÁRIO}

\section{RESUMO}

16 LISTA DE ABREVIAÇÕES E SIGLAS

18 INTRODUÇÃO

18 Pé e Fé que me movem na busca

23 Percurso da pesquisa

31 Meu pé no chão da realidade: Jardim da União

35 Organização da dissertação

\section{PONTOS DE PARTIDA: IDEIAS E QUESTÕES}

39 1.1. Economia de Francisco

47 1.2. Cidade produz ocupação: limites

54 1.3. Ocupação produz cidade: potencialidades

57 1.4. As representações sociais: cidade (in)formal?

63 1.5. As noções construídas em torno do termo periferias

65 1.6. Alinhavando alguns pontos

70 A INCIDÊNCIA DAS CEBS NAS PERIFERIAS PAULISTANAS

77 2.1. A busca pela liberłação

80 2.2. E a lgreja se fez povo

84 2.3. Uma Igreja em saída: o Clube de Mães

88 2.4. Postura extra-eclesial: o método

$91 \quad 2.5$. O destino das CEBs
98 ENTREMEIOS: BREVE CONTEXTUALIZAÇÃO DAS PERIFERIAS

99 3.1. Anos 1970-1980: o contexto das CEBs

103 3.1.1. Matrizes discursivas: quando novos personagens entraram em cena

110 3.2. Anos 1990-2000: inflexões e coexistência de mundos

116 3.2.1. Novas matrizes discursivas: quando os mais novos personagens entraram em cena

117 | "Paz entre irmãos”: expansão do mundo do crime e a guerra como rotina

127 || "Irmãos de fé": expansão do neopentecostalismo

133 III "Patrão de si mesmo": expansão do empreendedorismo

137 3.3. Pós 2000: heterogeneidade das periferias

148 PÉ NO CHÃO DA REALIDADE: A OCUPAÇÃO JARDIM DA UNIÃO

155 4.1. O massacre do Itajai

168 4.2. Lona: ocupação criança

174 4.3. Madeira: ocupação adolescente

180 4.3.1. A luta pela permanência

186 4.3.2. Plano Popular: instrumento de luta

198 4.4. Tijolo: ocupação adulta

205 4.5. CPPATHIS

208 4.5.1. Frentes de trabalho

225 4.6. Novas dinâmicas: paradoxo do desenvolvimento

256 CONSIDERAÇÕES FINAIS: NA BUSCA POR UMA POSSIVEL COSTURA

284 LISTA DE FIGURAS, GRÁFICOS, QUADROS E TABELAS

288 REFERÊNCIAS

304 ANEXO • Por uma arquitetura e urbanismo de libertação 
LISTA DE ABREVIAÇÕES E SIGLAS

Al-5 - Ato Institucional Número Cinco

ANVISA - Agência Nacional de Vigilância Sanitária

APM - Área de Proteção aos Mananciais

APRM - Área de Proteção e Recuperação de Mananciais

CDHU - Companhia de Desenvolvimento Habitacional e Urbano

CEB - Comunidade Eclesial de Base

CEBRAP - Centro Brasileiro de Análise e Planejamento

CEM - Centro de Estudos da Metrópole

CETESB - Companhia Ambiental do Estado de São Paulo

CNBB - Conferência Nacional dos Bispos do Brasil

CONLUTAS - Coordenação Nacional de Lutas

CPPATHIS - Curso de Prática Profissionalizante em Assessoria

e Assistência Técnica em Habitação de Interesse Social

CPT - Comissão Pastoral da Terra

CPTM - Companhia Paulista de Trens Metropolitanos

CUFA - Central Única das Favelas

DIEESE - Departamento Intersindical de Estatística

Estudos Socioeconômicos

DSI - Doutrina Social da Igreja

EG - Evangelii gaudium

ENEL - Ente nazionale per l'energia elettrica

FAU-USP - Faculdade de Arquitetura e Urbanismo da Universidade de São Paulo

FIES - Fundo de Financiamento Estudanti

FIPE - Fundação Instituto de Pesquisas Econômicas

FNRU — Fórum Nacional de Reforma Urbana

FUNAPS - Fundo de Atendimento à População Moradora

m Habitação Subnormal

IAU-USP - Instituto de Arquitetura e Urbanismo de São Carlos

BGE - Instituto Brasileiro de Geografia e Estatística

BOPE - Instituto Brasileiro de Opinião Pública e Estatística

HU - Instituto Humanitas Unisinos

IPCA - Índice Nacional de Preços ao Consumidor Amplo

LE - Lei Específica

JDU - Jardim da União

MBL - Movimento Brasil Livre
MCC - Movimento Contra a Carestia

MCMV - Programa Minha Casa Minha Vida

MCV - Movimento do Custo de Vida

MDF - Movimento de Defesa do Favelado

MLP - Movimento Luta Popular

MPL - Movimento Passe Livre

MTST - Movimento dos Trabalhadores Sem-Teto

OSC - Organizações da Sociedade Civil

PCC - Primeiro Comando da Capital

PDE-SP - Plano Diretor Estratégico de São Paulo

PEx-URb - Práticas de Pesquisa Ensino e Extensão em Urbanismo

PL - Projeto de Lei

PMSP - Prefeitura do Município de São Paulo

ProUni - Programa Universidade para Todos

PSDB - Partido da Social Democracia Brasileira

PT - Partido dos Trabalhadores

PUC-SP - Pontifícia Universidade Católica de São Paulo

RDD - Regime Disciplinar Diferenciado

Reurb - Regularização Fundiária Urbana

RJ - Rio de Janeiro

RMSP - Região Metropolitana de São Paulo

SABESP - Companhia de Saneamento Básico do Estado de São Paulo SMDET - Secretaria Municipal de Desenvolvimento Econômico e Trabalho

SP - São Paulo

SUAS - Sistema Único de Assistência Social

SUS - Sistema Único de Saúde

TEVAP - Tanque de Evapo-Transpiração

TFG - Trabalho Final de Graduação

UBS - Unidade Básica de Saúde

UF - Unidade Federativa

UMM - União dos Movimentos de Moradia

UNMP - União Nacional por Moradia Popular

USP - Universidade de São Paulo

ZEIS - Zona Especial de Interesse Social 


\section{INTRODUÇÃO}

Pé e Fé que me movem na busca

Na construção das representações sociais a biografia do autor tem o seu lugar, assim como as ideias e os discursos implícitos e explícitos no contexto de sua época. O pensamento de um determinado autor só pode ser compreendido quando se leva em conta o seu tempo, origem de classe, características sociais, políticas e religiosas, além do contexto intelectual em que circulava e se inseria (VALLADARES, 2005, p. 13).

Sem dúvida, minha produção - assim como de qualquer pesquisadora - é parte intrínseca da minha trajetória. No entanto, dada as condições impostas para minha classe de origem, o curso natural das coisas não me traria até aqui. Fui teimosa, da teimosia boa, ou ainda transgressora dessas imposições. Sou filha de migrantes nordestinos que vieram para São Paulo retirando-se da "vida severina" e trazendo na mala o sonho da casa própria, a tão almejada ascensão social via trabalho e o desejo de ajudar aqueles que ficaram no sertão paraibano. ${ }^{1}$ Típico do "projeto de família operária-católica", dos anos 1980, que tratarei muito durante a dissertação. Por isso, é possivel dizer que ao estudar os temas que me propus, compreendi ainda mais minha própria história.

Chegaram à capital paulista atraídos pelas promessas de emprego, mas logo perceberam que essas eram maiores que a realidade, bem como canta Caetano Veloso em Sampa: "e quem vem de outro sonho feliz de cidade, aprende depressa a chamar-te de realidade, porque és o avesso do avesso". Sem estudo, meu pai alternou entre cargos de porteiro e zelador. Por isso, posso dizer que sou a filha do porteiro de quem Paulo Guedes falou. Sou o "desastre" que ele mencionou para o projeto educacional brasileiro, já que, como 
bem pontuou Darcy Ribeiro, "a crise da educação no Brasil não é uma crise, é um projeto".

Pelo grande incentivo dado por minha mãe, fui encorajada a estudar. Ela sempre acreditou na educação como prática libertadora, ainda que nunca tenha lido Paulo Freire. Ela repetiu inúmeras vezes durante minha infância que o seu grande sonho era ter estudado, mas diante das imposições duras de sua vida, projetou esse sonho na vida dos filhos (que sorte a nossa!). Dessa maneira, as nossas trajetórias, minha e dos meus irmãos, foram muito distintas da dos nossos pais, típico das familias migrantes que tiveram seus filhos já na capital.

Prestei vestibulinho na oitava série e passei pelas cotas de escola pública (vivam as cotas!) em uma escola técnica com bolsa integral. Findado esse período, iniciou-se o ciclo da graduação e a preocupação de como arcar com os custos. Através do Programa Universidade para Todos (ProUni), criado sob o Governo do Lula, tive condições de acessar o ensino superior, portanto sou fruto de uma política pública (lutemos por elas!).

Sendo assim, essa pesquisa trata-se de pé, pois, sem dúvida, chão da realidade que piso conduziu (e tem conduzido) as minhas escolhas pessoais, profissionais e acadêmicas. $O$ ingresso na universidade só revelou ainda mais o abismo entre a minha realidade e o que eu tinha acesso, já que passei a minha infância morando em condomínios que meu pai trabalhava e cresci sem encontrar explicações em tamanhas assimetrias sociais, por exemplo, entre mim e as demais crianças do condomínio.

A graduação me despertava o incômodo de que a formação que recebia ali estava afastada do entendimento da realidade urbana da minha realidade, por exemplo. $O$ deslocamento faculdade-casa - cada trecho de cerca de 2 horas, três modais - mostrava o abismo entre esses dois mundos. E foi assim que, pouco a pouco, fui elaborando dentro de mim as escolhas e percursos que gostaria de trilhar, não sem esforços, já que eram raras as discussões nas disciplinas, de maneira que percebi que era fora da grade curricular que encontraria aquilo que fazia sentido para mim. Nessa trajetória encontrei professores comprometidos com a construção da cidade real, que, sem dúvida, impactaram definitivamente minha formação e sem o apoio e a condução deles eu não estaria aqui.
A pesquisa trata também de fé. Fé que extrapola o âmbito religioso, pois é a fé de que outros mundos são possiveis. No entanto, como sou nascida e formada em uma família católica é possível dizer que carrega um significado pessoal da minha relação com Cristo. Há tempos não me reconhecia nas reflexões que se afastam da construção de consciência crítica em relação às desigualdades sociais, levando as discussões muitas vezes para esferas individuais e espirituais. ${ }^{3}$ Sentia, por vezes, a contradição presente na Igreja entre aquilo que se discursava do que se praticava. Não compreendia tamanha naturalização das desigualdades e invisibilidade da pobreza.

Hoje, depois de meses imersa na realidade de uma ocupação urbana e de leituras que me ampararam, me considero uma mulher de fé que não dicotomiza mundanidade de transcendentalidade, pois o meu empenho social derivado da fé encarnada na realidade conflituosa não se opõe à minha espiritualidade. Parafraseando Paulo Freire, ao longo da pesquisa diante da dura realidade de tantos e tantas, encontrei em Marx a fundamentação objetiva para continuar camarada de Cristo, à medida que "fiquei com Marx na mundanidade à procura de Cristo na transcendentalidade". 4

Todas essas partes do meu eu - sou povo, cristã e arquiteta/urbanista - estão presentes de certa maneira nesta Dissertação já que "a leitura do mundo precede a leitura da palavra" (Paulo Freire). E, por serem muito pessoais, confesso que são difíceis de serem colocadas aqui. No entanto, considero necessário expor essa trajetória pessoal para que a pesquisa faça mais sentido (não somente para quem a lê, mas também para mim) e sirva como chave de leitura para esse trabalho. ${ }^{5}$ Assim, uma questão que se coloca de fundo é em relação à minha atuação enquanto arquiteta

3 Concordo com Boff (1986, p. 82-83) quando diz que [.... para ser um bom cristão é preciso preocupar-se também com a justiça social que e uma realidade politica. Hoje, para se alcançar esta justiça social, tăo carente em nossa sociedade discricionária, importa viver a fé como fator de transformação das relações sociais. Um cristão em nossa realidade brasileira que se opõe às mudanças qualitativas da sociedade não e so um cidadão conservador mas um cristão infiel ao Evangelho porque surdo ao clamor dos oprimidos que sobe de todas as partes".

4 Trecho extraido do vídeo em que Paulo Freire é entrevistado sobre sua re-

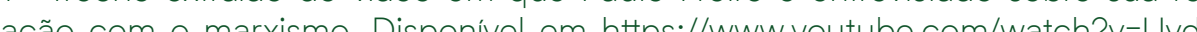
2YlcZkE. Acesso em 27/08/2021

5 A escrita deste texto foi incentivada pelo Professor Paulo Emilio durante a minha banca de qualificação. Aceitei o desafio e percebi o quanto realmente foi necessário me colocar, ainda que brevemente, sobre as minhas crenças, já que "as idelas se têm e nas crenças se esta" (Miguel de Unamuno). 
e urbanista na busca de transformação social, sabidamente difícil, mas possível e urgente. Uma busca muito pessoal, que parte do meu pé e da minha fé, não pela certeza do achado, mas por mover-me nessa busca. Busca que não é possível sem a esperança, já que ela é indispensável para o vislumbre do amanhã, e que se intensifica à medida que percebemos que não estamos sozinhos, já que o Brasil, como colocou Freire (1995), é uma terra de dor fome, miséria, mas é também de esperança de milhões, igualmente famintos de justiça. A certeza é de que ainda temos muito a caminhar, lutando juntos pela reinvenção do mundo.

\section{PERCURSO DA PESQUISA}

Ele [Riobaldo] sabe do que fala quando diz que o real não está no começo, nem no final, mas no meio da travessia. "Digo: o real não está na saída nem na chegada; ele se dispõe para a gente é no meio da travessia". São as veredas que fazem o Grande Sertão (Grandes Sertões: veredas, Guimarães Rosa).

Se eu já acreditava na frase "o caminho se faz caminhando", após a finalização desta Dissertação, ela se tornou ainda mais verdadeira. Por mais que busque demonstrar os "descaminhos" que construíram as veredas percorridas nessa travessia, sem dúvida, a escrita não dará conta de transmitir as inquietudes e as nebulosas enfrentadas nessa jornada até aqui. Nada do que será exposto nasceu pronto, mas é resultado de um longo e contínuo processo de (des)construção, ao longo dos trinta meses que constituíram essa pesquisa, mas que sem dúvida foi iniciado muito antes da entrada ao mestrado.

Quando ingressei, trouxe comigo a intenção de ter como categoria analítica o estudo do cotidiano daqueles que lutam todos os dias pelo direito de existir e resistir na cidade. Cotidiano aqui, pelo menos a princípio, não teorizado, mas praticado, ${ }^{6}$ pois carrego, para além da minha origem, a experiência que tive durante o Trabalho

6 Apesar de a princípio não ser o cotidiano teorizado, ao longo do Trabalho Final de Graduação o historiador Michel de Certeau (1994) foi um dos principais referenciais teóricos para tratar da "vida cotidiana", já que segundo ele: "a fixidez do habitat, o costume reciproco da vizinhança, os processos de reconhecimento/ identificação, que se estabelecem graças à coexistência concreta em um mesmo território urbano, todos esses elementos "práticos" se oferecem como imensos campos de exploração em vista de compreender um pouco melhor esta grande desconhecida que é a vida cotidiana".
Final de Graduação em que pude ao longo de meses partilhar a vida com adolescentes de Paraisópolis (SP) e fazer dessa experiência a construção do meu próprio cotidiano. ${ }^{7}$ Dessa maneira, a pesquisa resulta de inquietações que trago e elaboro desde a graduação, ainda que naquele momento de maneira incipiente, com pouca fundamentação na literatura já consolidada dentro da academia, mas embasada no chão que piso. Após a entrada no mestrado descobri diversos autores e pesquisas que contribuíram de maneira incisiva para um melhor entendimento.

A ideia do estudo do cotidiano sempre foi algo que me estimulou porque acredito que a investigação das práticas cotidianas, para além da importante leitura da realidade que possibilita, contribui para pensar de maneira diferente, pensar o novo, ampliar possibilidades e perspectivas. Portanto, a vida cotidiana aqui é entendida como aquela que indica possíveis caminhos.

É justamente isso que busco formular, desde a graduação, quando me refiro às ocupações urbanas, ${ }^{8}$ pois defendo que tais ter-

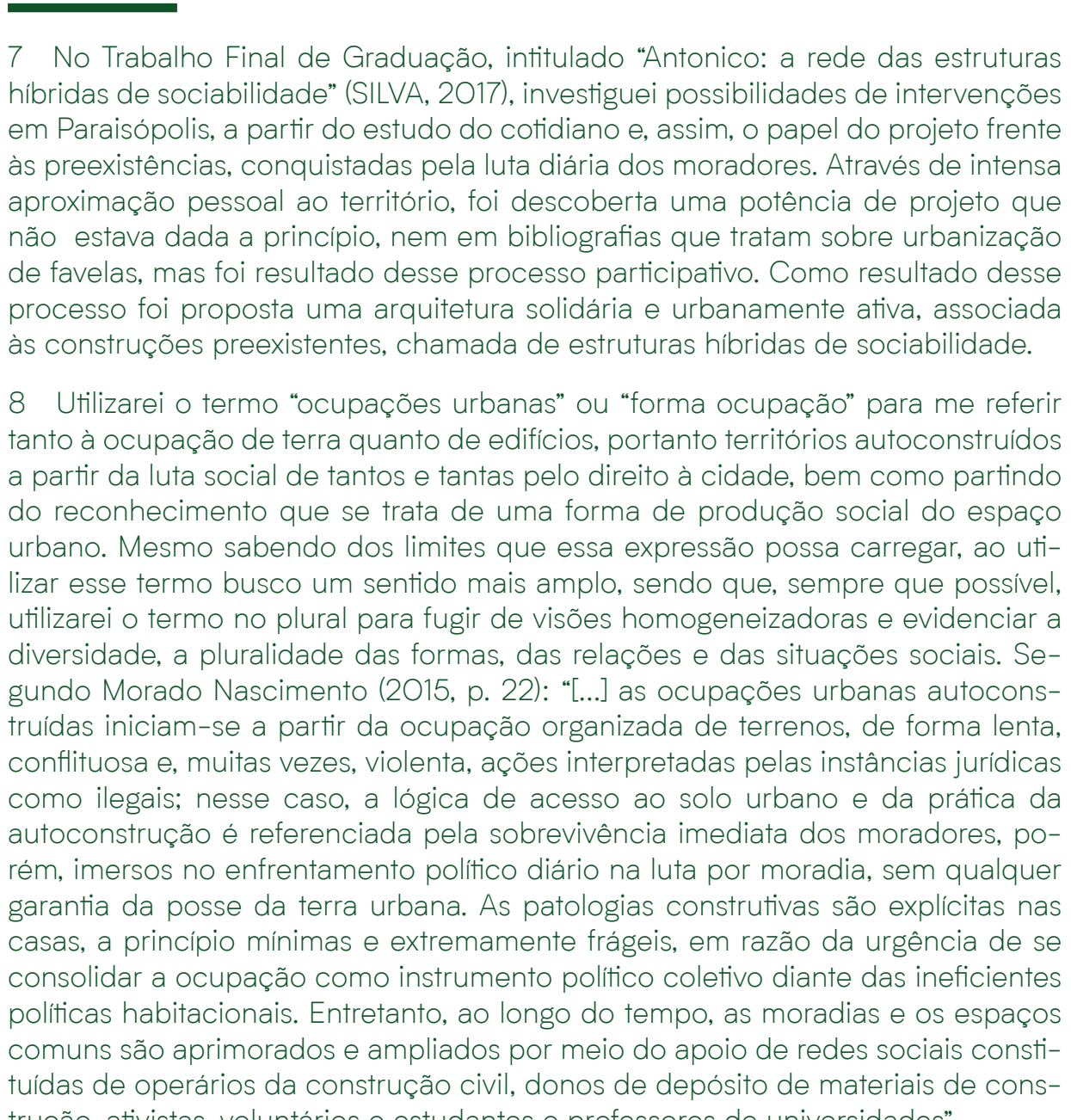
trução, ativistas, voluntários e estudantes e professores de universidades" 
ritórios têm muito a ensinar, uma vez que considero que não se tratam apenas de uma forma de morar, mas uma forma de vida e de produção da cidade. Essa defesa se dá, sobretudo, quando percebo que há um abismo entre a nossa formação e a construção da cidade real, o quanto o estudante de arquitetura e urbanismo é afastado do entendimento da realidade urbana.

Após diversas experiências que me trouxeram até aqui, boa parte ao longo do mestrado, e que extrapolaram os muros da universidade, tenho percebido o quanto a prática profissional não é exclusivamente técnica, tampouco neutra, mas sobretudo política, pois pode tanto reproduzir opressões, como aspirar transformação social.

Foi em busca dessa aspiração que decidi ingressar no mestrado e a partir desse desígnio fui construindo o projeto de pesquisa. Algumas questões se constituem como fios de ouro para entendimento desta pesquisa: (1) a importância do trabalho de base, o pé no chão da realidade, pois acredito que a prática popular é capaz de criar o projeto alternativo de sociedade, ou seja, a mudança se dará sobretudo pela ação coletiva; (2) a busca de outros mundos possíveis, ou seja, a fé na construção de cidades mais justas, e igualitárias; (3) as ocupações urbanas como uma forma de produção social do espaço urbano, constituindo-se como expressão de resistência, bem como de potência transformadora; (4) a política presente nas lutas cotidianas dos sujeitos periféricos (D'ANDREA, 2013), já que a política está na base das noções sobre direito cidadania e democracia que estes sujeitos pretendem formular Mas ao falar de política, a violência se interpôs como uma temática que não poderia deixar de abordar. Portanto, as relações entre política e violência que marcam o cotidiano desses territórios e de seus moradores. ${ }^{9}$

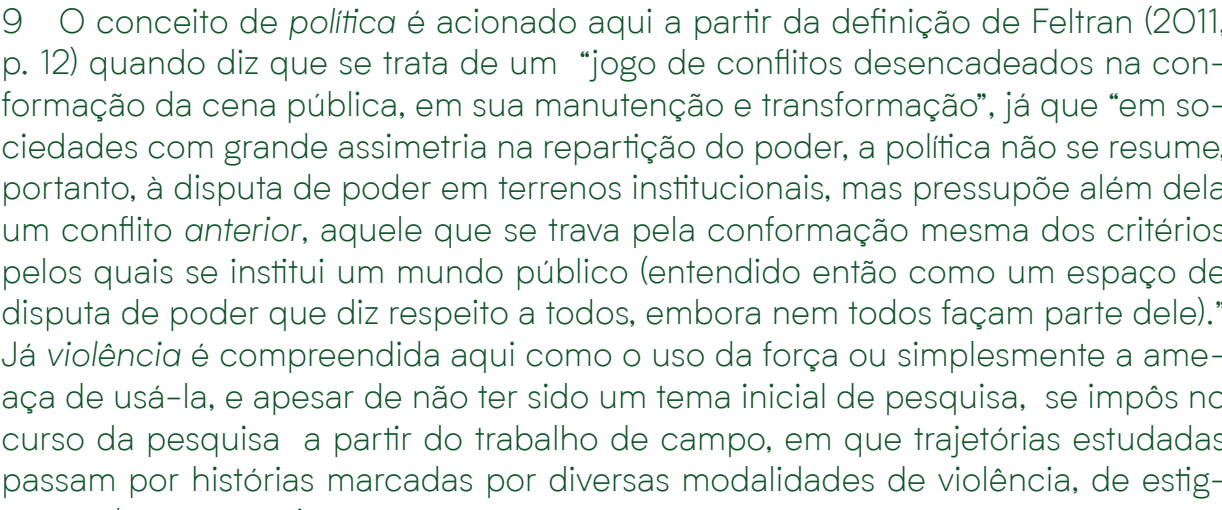

Num movimento de me deixar afetar e conduzir pelas questões trazidas pelos meus pés no chão, o trabalho de campo era um pressuposto pessoal, pois somente através dele entendia ser possíve depreender esses quatro pontos citados. Nesse sentido, participar do Curso de Prática Profissionalizante em Assessoria e Assistência Técnica em Habitação de Interesse Social (CPPATHIS) no primeiro semestre do mestrado foi crucial, pois tive a oportunidade de uma imersão intensa e afetuosa com os moradores da ocupação urbana no Jardim da União, localizada no extremo sul da cidade de São Paulo, que não se findou com a conclusão do curso, de maneira que segue até hoje e extrapola os limites da pesquisa. Essa experiência, a princípio, não seria tratada na dissertação, mas após a banca de qualificação ficou evidente que boa parte das reflexões presentes no Memorial partiam dessa aproximação e relação construída. Assim, ao final da banca ficou entendido que esse deveria ser meu campo.

Outro divisor de águas para a pesquisa foi a aprovação para participar do movimento The Economy of Francesco. Em suma, visto que será melhor detalhado a frente, a Economia de Francisco originou-se a partir do chamado, em 2019, do Papa Francisco para que jovens de diferentes lugares do mundo pensassem numa "nova economia". Uma economia que faça viver e não mate, que inclua e não exclua, que de fato sirva a todos, sem exceção (FRANCISCO, 2019). Participar desse movimento me deu ainda mais clareza da raiz econômica das mazelas sociais, no sentido de que a assimetria socioeconômica não é mero acaso, mas uma escolha prévia de um sistema que coloca interesses econômicos acima do desenvolvimento integral humano. $\mathrm{E}$, pensando a partir da minha área de estudo, é preciso uma mudança radical e estrutural do sistema econômico para alcançarmos a tão sonhada democratização da cidade. Nesse sentido, participar da Economia de Francisco colocou meus pés ainda mais no chão, pois contribuiu para que eu conseguisse elaborar uma leitura das ocupações urbanas não somente a partir do seu potencial transformador (como eu fazia a princípio), mas considerando também as contradições e limites a partir do reconhecimento de que estão inseridas no modo de produção capitalista contemporânea.

A partir desse envolvimento, entendemos que um caminho interessante seria a recuperação histórica da atuação da lgreja Católica, mais especificamente o período de atuação das Comunidades Eclesiais de Base (CEBs) nas periferias paulistanas. Com esse 
histórico pretendeu-se enfatizar um contexto de protagonismo do poder local e trabalho realizado com a mobilização popular no território, em que parte da Igreja Católica contribuiu e fortaleceu a luta social e cotidiana dos moradores, estes reconhecidos enquanto sujeitos políticos e históricos, na reivindicação de direitos. Portanto, nas décadas de 1970 e 1980 a Igreja Católica teve um importante papel na politização dos movimentos sociais da periferias paulistanas através das CEBs, na defesa da permanência dos moradores, da conquista de direitos, na construção de consciência política e crítica, bem como da função social da cidade. Essa recuperação histórica é importante como uma tentativa de retomada do protagonismo do poder local, pois considera-se que a reconquista da democracia brasileira e da construção de uma outra economia somente acontecerão em um processo que parta da mobilização da base e da prática popular.

Explicados os momentos de inflexão iniciais, o projeto de pesquisa foi revisto e buscou responder às questões: Como as práticas cotidianas populares $^{10}$ - dos sujeitos periféricos - produzem espaço urbano? Quais as potências e limites presentes nessas práticas para a real democratização das cidades? Dessa maneira, o objeto de pesquisa passou a ser o entendimento da relação entre a luta social daqueles que reivindicam o direito à cidade a produção do espaço urbano, a partir de sua prática cotidiana. E tendo como objetivo geral: o estudo do cotidiano a fim de investigar a política presente nas lutas sociais populares, que partem do pé chão das suas realidades e da fé em outros mundos possíveis. E os seguintes objetivos específicos: (1) romper a visão dicotômica das diversas formas de produção do espaço urbano; (2) recuperar parte da história da atuação das Comunidades Eclesiais de Base nas periferias paulistanas; (3) abordar a trajetória de uma ocupação urbana recente, que tem como como horizonte a pergunta: como se produz cidade hoje? ${ }^{11}$; (4) contribuir para

10 O conceito de práticas cotidianas ao longo da pesquisa está amparado em Certeau (1994, p. 187), pois segundo o autor "são constitutas diálogo permanente entre passado e presente, como da justaposição das dimensões qualitativamente heterogêneas de espaço e tempo".

I O conceito de trajetória também está amparado em Certeau (1994), que a coloca como um movimento temporal no espaço. Semelhante a essa visão Telles (2006) faz uso da expressão processos situados, para se referir a processos que operam em situações especificas de tempo e espaço. Sendo assim, compreender as trajetórias urbanas permite apreender a maneira como se dá a produção do espaço urbano, como por exemplo, a partir de um processo situado no tempo e no espaço como a ocupação Jardim da União. a reconstrução do campo progressista brasileiro, em tempos de ameaça à nossa democracia e de negacionismo científico. ${ }^{12}$

Entre idas e vindas, o argumento central da pesquisa foi sendo (re) construído em um percurso nada linear. ${ }^{13}$ Dessa maneira, passei a defender que existe uma relação dialética entre cidade produz ocupação, ao mesmo tempo em que ocupação produz cidade, e é a partir desse entendimento que a pesquisa foi desenvolvida. Dizer que a cidade produz ocupação significa reconhecer que está inserida dentro do regime de produção capitalista do espaço, no qual a cidade é entendida enquanto mercadoria, sendo a ocupação resultado precarizado desse processo. Tal entendimento ficou muito aguçado após minha entrada na Economia de Francisco. Ao mesmo tempo, a ocupação produz cidade no sentido de reconhecer a forma ocupação como parte integrante da produção da cidade, ou seja, uma forma de produção social do espaço urbano. Nesse sentido se constitui, não somente pela necessidade do morar, mas também como resistência a um contexto sociopolítico

2 Tempos dificeis e desafiadores, nos quais em 2019 foi eleito um presidente de extrema-direita, que logo que tomou posse extinguiu o Ministério das Cidades e fomenta a criminalização de movimentos sociais que lutam pelo direito a cidade. Sobreviver a pandemia ja seria desafiador em qualque conjuntura, pior ainda com Brasil sendo presidido por alguém que a descreve como "gripezinha", nega vacina e que não segue as recomendações necessarias. Vivemos um contexto de desmonte das polificas de inclusão na educação, de negacionismo cientifico e de perseguição a Paulo Freire, nosso patrono da educação e que esse ano completa seu centenário, e, portanto critica crica, indispensavel para emancipaça da condiça de oprimido, Portanto.

13 A problemática inicial elaborada no âmbito da disciplina Da construção da Casa à Indústria Imobiliária: espaço e politica (AUH5864), cursada no primeiro semestre do mestrado (1/2019), tratava da ocupação como (des)mercantilização da terra, no sentido de refletir a respeito da relação dialética entre duas possiveis relações entre apropriação de terra na forma "ocupação". A primeira lendo a ocupação enquanto mercantilização da terra, ou seja, resultado da produção desigual de cidade no capitalismo periférico e entendida muitas vezes como reserva de terra, para quando necessário segundo interesses capitalistas retorna à circulação (valor de troca). Enquanto que na segunda entendia-se ocupação enquanto desmercantilização da terra, como uma forma de apropriação da terra não mercantil, uma resistência à produção do espaço pelo capital (valor de uso). Portanto, duas perspectivas: a ocupação como impulso para expansão do capital, dialeticamente como resistência ao capital, sendo que dessa última advém sua potência transformadora no sentido de explorar possiveis caminhos emancipatórios para a desmercantilização de bens essenciais à vida, como a terra. Com o desenvolvimento da pesquisa, bem como a partir da leitura dos estudos das pesquisadoras Rosa $(2008,2014)$ e Viana (2020), esse argumento foi revisado. 
econômico que é por natureza desigual e excludente, e daí advém a sua potência transformadora, no sentido lefebvriano.

Trazer os termos cidade e ocupação individualizados pode parecer que são conceitos diametralmente opostos, quando na verdade um dos objetivos específicos da pesquisa, como já exposto, é justamente superar a visão dicotômica que muitas vezes apresenta uma "cidade dividida" entre regular e irregular, formal e informal, centro e periferia, cidade e ocupação. Considera-se que essa visão dualista obscurece a noção de que todas essas construções fazem parte de um único e complexo processo que é o da produção do espaço urbano. Mas que muitas vezes são descritos em oposição por ser resultado de um enquadramento socialmente produzido. Assim, a pergunta de fundo que se estabelece é: "não seria a mesma cidade que produz as ocupações e que é produzida por elas?" (ROSA, 2008). Parto do pressuposto que dentro de uma dita "cidade" existem várias cidades, ou seja, diferentes formas de produção do espaço urbano. Sendo a ocupação uma dessas formas, ou ainda, uma dessas cidades, já que:

Plural de cidade são as cidades que existem dentro da cidade. Não é um conjunto diverso de cidades, nem uma questão de geografias. Plural de cidade são os territórios díspares que fazem a cidade, as políticas sociourbanas e a sua ausência, o atropelo aos direitos e as paisagens de privilégio, as formas de segregação ostentação, a cultura, a saúde, o emprego, o dinheiro, o futuro e, ao mesmo tempo, a falta de todos eles. Plural de cidade é conjugação destas cidades numa só. E em todas elas (FORTUNA; LEITE, 2015, p. 7).

Revisado o projeto de pesquisa inicial, o percurso metodológico contou com revisão bibliográfica que foi concomitantemente alimentada e revisada a partir das temáticas trazidas pelo trabalho de campo. Contou também com importantes entrevistas e conversas com pesquisadores e/ou militantes ligados aos temas trabalhados, a saber: (1) Profa. Dra. Ermínia Maricato, que tem importante atuação nas periferias paulistanas, desde o contexto das CEBs, e cujo trabalho se constitui como referencial para o desenvolvimento desta pesquisa; (2) Selvino Heck, militante nas CEBs e colunista do "Brasil de Fato"; (3) Evaniza Rodrigues, membra da União Nacional por Moradia Popular (UNMP) e que também iniciou sua militância a partir da participação nas pastorais católicas; (4) Peterson Prates, coordenador da CEB de Sapopemba e jovem participante do movimento Economia de Francisco; (5) Prof. Dr. Gabriel Feltran, pesquisador com trabalho etnográfico nas periferias paulistanas e cuja produção também é referencial teórico relevante da pesquisa. Essas entrevistas foram fundamentais para construir a reflexão a respeito da atuação das CEBs na construção das periferias paulistanas, como também as mudanças ocorridas nas décadas seguintes. Graças a minha participação na Economia de Francisco, tive contato com diversos pesquisadores e/ou ativistas, e pude participar de lives e seminários, com nomes como Leonardo Boff, Maria Lucia Fattorelli e Ladislau Dowbor. ${ }^{14}$ Fundamos a Coluna "Rumo a Assis: na direção da Economia de Francisco" no portal Instituto Humanitas Unisinos (IHU), com texto inaugural intitulado "Vão, Jovens de Francisco, e reconstruam a nossa economia, que, como veem, cai em ruínas!" (SILVA et al., 2020). Vale destaque também à publicação do artigo "Um olhar crítico e construtivo sobre a cidade à luz da Economia de Francisco", na revista Vida Pastoral (SILVA; RAUPP; BRASILEIRO, 2O21). Já as conversas com os moradores do Jardim da União contribuíram para parte do entendimento de "como se produz cidade hoje" e esse percurso será melhor explicado no próximo tópico, que é dedicado ao trabalho de campo.

\section{MEU PÉ NO CHÃO DA REALIDADE: JARDIM DA UNIÃO}

O primeiro contato com a ocupação urbana Jardim da União foi através do Curso de Prática Profissionalizante em Assessoria e Assistência Técnica em Habitação de Interesse Social (CPPATHIS), realizado entre janeiro e junho de 2019. Esse período corresponde ao primeiro semestre do mestrado e, portanto, ser monitora nesse curso contribuiu de forma direta para a elaboração das questões e reflexões trabalhadas ao longo da pesquisa, bem
4 Como palestrante participei dos seguintes eventos: Economy of Francesco - PUC/SP, Economia de Francisco: a construção de uma economia que faz vive e não mata - IHU, Laudato Si': Juventudes para novas economias, Videoconferencia Lutas Sociais e Economia de Francisco e Clara, Mesa de Diálogo sobre a (conomia de Francisco e Clara e da Semana de Formação Diocesana da cidade de Guarulhos. Como debatedora participei de uma das doze conferências oficials do The Economy of Francesco, intitulada Socio-Ecological Responsibility: global view, territorial actions e do evento O Fascinio dos 2 Franciscos para as pessoas e nosso tempo, realizado pela PUC-SP. Todas essas participações contribuiram de forma incisiva para o desenvolvimento desta pesquisa. 
como a primeira aproximação ao campo desta pesquisa. ${ }^{15}$

O CPPATHIS foi organizado pela Peabiru Trabalhos Comunitários e Ambientais e pela Faculdade de Arquitetura e Urbanismo da Universidade de São Paulo (FAU-USP) e destinou-se a arquiteto(a)s e urbanistas com até cinco anos de formação. A escolha da ocupação urbana Jardim da União para realização das atividades se deveu às relações construídas desde 2017 entre a comunidade e a Peabiru TCA.

O curso foi coordenado pelos professores Caio Santo Amore, Karina Oliveira Leitão e Maria Lucia Refinetti Martins, com a colaboração de professores, pós-graduandos e especialistas com experiência em assessoria técnica e contou com a participação 25 cursistas (selecionados entre os 177 inscritos) e 11 monitores.

Dividido em aulas teóricas, às sextas-feiras na FAU-USP, e atividades práticas no Jardim da União, aos sábados e domingos, o curso possuía um programa prévio para as aulas teóricas que teve alterações ao longo dos seis meses de duração. Isso foi resultado da relação horizontal e dialógica construída com os moradores.

A imersão no cotidiano da ocupação, possibilitada pelo curso, não se findou ao término deste, pois ainda que em frequência menor, fui diversas vezes ao Jardim da União durante os semestres que sucederam o término do curso e mantive contato com alguns moradores. Inclusive, durante a pandemia, ainda que inicialmente sem intenção de pesquisa. Mais recentemente (maio-julho/2021) tenho ido com mais frequência, pois estamos no momento de aplicação de um novo censo, que será melhor explicado no capítulo 4, mas quero destacá-lo como possibilidade de criação de vínculos sociais. As caminhadas com as moradoras pelo Jardim da União sempre trouxeram descobertas (tanto para mim, quanto para elas) e foi através delas que elaborei muitas das reflexões que constam aqui. $O$ caderno de campo, nesse sentido, também foi um importante instrumento de pesquisa ${ }^{16}$.

15 Participei da elaboração de algumas publicações que tratam a respeito dess experiência: (CABRAL; SILVA; TESTOLINO, 2O2O; HADDAD et al., 2019; SILVA et al., 2019).

6 Optei por não trazer o caderno de campo na dissertação por conter informações que poderiam expor meus interlocutores. Além disso, no contexto de pandemia, o caderno se transformou em um diário, ou seja, não somente o lugar onde sistematizei as informações que o campo me trazia, mas também um lugar de registro do meu cotidiano, como pesquisadora vivendo esse tempo de isolamento social e todas as questões e angústias que atravessaram esse periodo.
Portanto, dessas relações construídas ao longo do tempo e dos muios diálogos informais, como as caminhadas, um café da tarde ou almoço, advém as informações e registros dessa pesquisa. A cada ida a campo muita coisa mudava, tanto no território, quanto na visão dos moradores e na minha própria, e para além das coisas visíveis (que eu poderia notar assim que entrava na ocupação), eram a partir das conversas que eu buscava entender os pormenores, questões que sozinha ou somente a "olho" não seriam possiveis depreender Sinto que ao longo desses dois anos e meio construímos uma relação de confiança no sentido freiriano, mas não isento de angústias por sentir que sempre trazia mais do que deixava, até que comece a perceber que na realidade estávamos construindo uma relação de parceria, de deixar e receber um tanto, parafraseando a canção Mistério do Planeta dos Novos Baianos.

Dessa maneira, os dados presentes ao longo do trabalho foram coletados de dois modos: (1) das conversas com os moradores, que referenciei como "nome do morador(a), informação verbal, ano" e (2) do material proveniente do CPPATHIS, que está referenciado como "nome do morador, CPPATHIS, 2019". Todos os nomes dos moradores citados ao longo do trabalho são fictícios na tentativa de preservar suas identidades e para que não sejam prejudicados em alguma medida por terem compartilhado comigo informações, ainda que reconhecendo os limites dessa "estratégia”, já que não alterei, por exemplo, o nome da ocupação. ${ }^{17}$

Visto que a pesquisa foi atravessada pela pandemia, o que impossibilitou muitas vezes as idas ao campo (ainda que eu tenha ido diversas vezes seguindo os protocolos de segurança), a coleta de dados a partir do material produzido no âmbito do CPPATHIS foi de extrema importância para seu desenvolvimento. Esse é um ponto, inclusive, que merece destaque, pois como fui de forma mais espaçada ao Jardim da União, por conta do isolamento social, a cada ida eu percebia muitas mudanças, talvez mais "fáceis" de serem processadas se pudesse acompanhar "mais de perto" as novas dinâmicas. Levei um bom tempo para "decantar as ideias", ou melhor, sinto que ainda estou nesse processo de decantação, por isso não

17 Como demonstra Fonseca (2005, p. 9): "todos nós reconhecemos que o uso de nomes fictícios não garante o anonimato aos informantes. Justamente porque a descrição densa depende da riqueza dos detalhes contextuais - tanto do local, quanto do individuo [...] O pesquisador anda numa corda bamba, procurando garantir a riqueza de detalhes que mantém fidelidade ao texto etnográfico, ao mesmo tempo que exerce uma vigilância constante aos limites éticos de sua ousadia". 
me isento de possíveis equívocos em minha leitura e interpretação daquilo que o campo me trazia, já que "nenhum objeto de pesquisa se destaca por sua evidência: o olhar do pesquisador e sua abordagem é que the delimitam os contornos" (LEPETIT, 2001, p. 39).

Dessa maneira, é possível afirmar que o campo conduziu a pesquisa, ou ainda, que a pesquisa é muito permeada pelo campo e suas mudanças. As questões e temas que surgiam me levavam a buscar na bibliografia algum tipo de embasamento e foi assim que fui construindo meu referencial teórico (e não o processo contrário). Algo muito importante e valioso para esse trabalho, pois sendo o objetivo principal o estudo do cotidiano a partir da política presente nas lutas sociais populares, meu pé sempre esteve no chão dessa realidade.

Ao analisar a trajetória do Jardim da União busquei identificar, a partir das práticas cotidianas, os atores sociais e as relações de poder, permeadas por tensões, conflitos e contradições, que se dão na busca pela produção desse território. A tentativa é que a trajetória da ocupação Jardim da União possa iluminar as especificidades da produção contemporânea da cidade. Dessa maneira foi fundamental a leitura dos acontecimentos cotidianos, os quais contribuíram para as reflexões elaboradas ao longo dessa pesquisa, assim como Feltran (2011, p. 3) ao relatar as histórias de vida e "as tensões que marcam essas histórias, tento compreender o sentido político das transformações que dão contexto ao conflito social inscrito nas periferias da cidade". Penso que é fundamental olhar para os conflitos sociais, e não sufocá-los, já que para além de demonstrar as desigualdades e contradições, possibilita refletirmos sobre possibilidades de alargamento do exercício democrático da política.

Entendo que a ocupação Jardim da União é resultado da organização coletiva de trajetórias individuais o que faz com que a história da ocupação muitas vezes se confunda com a história dos próprios moradores. Para falar de ocupação necessariamente fala-se sobre a vida, de mundos íntimos, privados, sociais até chegar aos espaços públicos. As narrativas dos moradores demonstram as suas percepções (individuais e coletivas) sobre as dimensões privadas e públicas da sociedade e possibilitam um caminho fecundo (e complexo) para a investigação política (FELTRAN, 2O11). Investigação política no sentido de como os moradores desses territórios produzem e conduzem suas existências e suas lutas cotidianas, ou seja, a luta política do povo em movimento.
Dessa maneira, ao longo da Dissertação, para retratar a trajetória do Jardim da União, busquei priorizar as falas e as práticas dos moradores, ou seja, a maneira como eles refletem sobre suas ações e sobre suas vidas. E não uma ordem "externa", muitas vezes proveniente do olhar viciado do pesquisador que tenta impor sua visão de mundo. Como bem coloca Cavalcanti (2009, p. 71) referenciando Certeau, não um olhar "do alto" em que o pesquisador assume um "olhar solar, olhando para baixo como um Deus", já que essa perspectiva muitas vezes "produz suas próprias categorias analiticas e descritivas", que acabam impondo reflexões e indagações que não correspondem à realidade vivida nesses territórios. Realidade que só é "acessada" a partir da perspectiva "do chão", elaborada a partir do trabalho de campo, continuado, que requer tempo e comunhão entre os envolvidos, uma vez que "a cabeça pensa a partir de onde os pés pisam" (Frei Betto). Dito isso, quero finalizar esse texto sobre o campo com algumas das inquietações e indagações trazidas por Morado Nascimento que, em certa medida, foram compartilhadas por mim nesse percurso:

Pergunto a todos os pesquisadores das questões da cidade: porque e em nome de quê ou de quem vamos às favelas e às ocupações? Em nome da academia e das nossas nobres metas da pesquisa ou da extensão? É possível conhecer e viver esses territórios a partir do nosso olhar? Quem se beneficia do que? O que fazemos com opiniões, dados, histórias e lutas cotidianas dos moradores desses

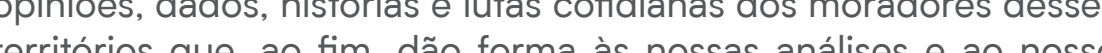
territorios que, ao fim, dâo forma as nossas anallises e ao nosso sucesso acadêmico? Qual é a nossa postura diante de territórios imersos pela historia da escravidão, da domestificação, da subor dinação e da servidão? (MORADO NASCIMENTO, 2019, p. 241). 


\section{ORGANIZAÇÃO DA DISSERTAÇÃO}

A dissertação está dividida em 6 partes, sendo a primeira esta introdução, seguida de quatro capítulos e das considerações finais. $\mathrm{Na}$ introdução, descrevo minha origem, necessária como chave de leitura para a pesquisa, os percursos de pesquisa e metodológicos, onde explico as mudanças e inflexões, bem como minha relação com a ocupação Jardim da União.

No Capítulo 1, explico quais foram meus pontos de partida, portanto as ideias de fundo e questões motivadoras para a pesquisa como um todo. $O$ primeiro ponto se refere à Economia de Francis$c o$, onde explico esse movimento global e suas origens, trazendo como fundamentação os discursos e escritos do Papa Francisco. Considerou-se importante iniciar a dissertação com esse ponto porque, em certa medida, ele foi o despertar de muitas das indagações e questionamentos que estão presentes ao longo da dissertação, inclusive motivador para o estudo das CEBs. No segundo e terceiro pontos, explico mais detalhadamente meu argumento sobre a relação dialética existente entre cidade produz ocupação e ocupação produz cidade. No quarto ponto, trago alguns olhares de autoras que também discutiram a respeito das representações sociais em torno das cidades. Já no quinto ponto, busquei explicar as noções em torno do termo periferia e porque decidi utilizá-lo ao longo do texto. E, por fim, busquei alinhavar esses pontos.

O capítulo 2 trata da atuação de parte da Igreja Católica junto à luta do povo a partir da incidência das CEBs, sendo o recorte as periferias paulistanas. Participar da Economia de Francisco me motivou resgatar um período da história em que a lgreja progressista realizava um trabalho de base enraizada no chão desses territórios e de resistência ao regime autoritário da época. Penso que esse resgate é importante, inclusive, como ventos de esperança para nossos tempos atuais. Como dito, para além da bibliografia específica, a construção desse capítulo contou com as entrevistas realizadas com pesquisadores e/ou militantes da época.

O capítulo 3 veio da necessidade de compreender o contexto histórico, tanto da época das CEBs, quanto das mudanças ocorridas nas décadas seguintes. Chama-se entremeio porque se coloca como uma breve recuperação dos momentos históricos trabalhados na pesquisa, em que trago as matrizes discursivas e os principais atores sociais. Ao trazer esse panorama, pretendeu-se problematizar essas mudanças nos elementos que antes eram considerados categorias fundadoras das periferias e demonstrar como que ao longo das décadas as periferias se tornaram cada vez mais heterogêneas e diversificadas.

O capítulo 4 traz a trajetória da ocupação Jardim da União, desde o início com a ocupação violentamente removida do ltajaí até as mais novas dinâmicas (refere-se ao primeiro semestre de 2021). Procurei identificar quais os atores sociais envolvidos e seus discursos, as relações de poder, disputas e negociações, atravessados por conflitos e tensões, que produziram determinada espacialidade, na tentativa que esta trajetória pudesse iluminar as especificidades da produção contemporânea da cidade, ou ao menos apontar caminhos, já que se trata de um processo situado no tempo-espaço e não tem a pretensão de uma abordagem generalista.

Na última parte, considerações finais, procuro estabelecer algumas costuras para os pontos levantados e alinhavados ao longo do trabalho. Um caminho que se mostrou fértil foi o de analisar tais contextos (CEBs e Jardim da União) a partir dos deslocamentos e permanências ao longo das décadas. Isso permitiu também entender mais a fundo como as práticas populares, a partir das lutas sociais engendradas pelos sujeitos periféricos, produzem espaço urbano. $\mathrm{E}$, ainda, quais os limites e potencialidades para a real democratização das cidades, que, ao fim, era a pergunta principal deste trabalho. 
PONTOS DE PARTIDA:

ideias e questões

\subsection{ECONOMIA DE FRANCISCO}

A Economia de Francisco nasceu a partir do chamamento do Papa Francisco, através da publicação de uma carta convite para o evento intitulado Economy of Francesco. A convocação se dirigiu sobretudo a jovens pesquisadores e ativistas para um encontro mundial com objetivo de pensar, nas suas palavras, uma "economia diferente, que faz viver e não mata, inclui e não exclui, humaniza e não desumaniza, cuida da criação e não devasta" (FRANCISCO, 2019, s/p.).18

A premissa é que essa nova economia deve servir à sociedade, ${ }^{19}$ e não o contrário, ao construir "outras formas de entender a economia e o progresso, em combate à cultura do desperdício, para dar voz àqueles que não a têm, para propor novos estilos de vida". Para ser contra uma "economia que mata", é preciso "mudar as

\footnotetext{
8 É importante explicar que o nome Francisco não se refere ao Papa, mas à vida de São Francisco de Assis, que em sua juventude despojou-se de todos os seus bens para doar-se inteiramente aos mais empobrecidos. Para o Papa, isso Jorge Bergoglio escolheu o nome Francisco para seu magistério papar isso Jorge Bergoglio escolheu o nome Francisco para seu magisterio papal. cão de uma outra economia, pois é exemplo de uma vida em coerência ao Evangelho de atencão aos Papa, São Francisco ferece um idea lavras: "Francisco despojou-se de toda a mundanidade para escolher peus como Estrela polar da sua vida, fazendo-se pobre com os pobres irmão universal. Da sua escolha de pobreza brotou também uma visão da economia que permanece extremamente atual. Ela pode dar esperanca ao nosso amanhã, não apenas em beneficio dos mais pobres. mas da humanidade inteira. Aliás ela é necessária para o destino de todo o planeta, a nossa casa comum. a nossa irmã Terra Mãe como Francisco a chama no seu Cântico do Irmão Sol" (FRANCISCO, 2019, s/p). 
regras do jogo econômico", "que a política não esteja a serviço das finanças." Assim, convida a todos para um "pacto" a fim de mudar a atual economia e dar uma alma à economia do amanhã é preciso "re-almar a economia" (FRANCISCO, 2019, s/p.).

A iniciativa desse encontro teve como objetivo desencadear processos, ${ }^{20}$ onde o evento era entendido, portanto, como um ponto de partida e não de chegada. No âmbito do encontro virtual, o Papa Francisco dirigiu as seguintes palavras "para mim este encontro virtual em Assis não é um ponto de chegada, mas o impulso inicial de um processo que somos convidados a viver como vocação, como cultura e como pacto" (FRANCISCO, 2020a, s/p., grifo meu). ${ }^{21}$

Viver como vocação no sentido de que devemos incidir concretamente nas realidades que estamos inseridos, com os pés no chão da nossa realidade, portanto, nas nossas cidades, universidades, movimentos, trabalhos etc., nos espaços onde temas são debatidos e decisões tomadas. Na Exortação Apostólica Evangelii gaudium (EG), ${ }^{22}$ o Papa reforça que a todo momento precisamos fazer uma leitura atenta da realidade, estudar os sinais do nosso tempo, pois ao realizar esse exame, que seria a etapa do "ver" presente no método ver-julgar-agir, nos damos conta da urgência de uma nova economia, que parta da lógica do desenvolvimento humano integral (PONTIFíCIO CONSELHO JUSTIÇA E PAZ, 2004). Essa é a nossa vocação.

20 A princípio o encontro aconteceria presencialmente em março de 2020 na cidade de Assis, trallia. Mas por conta da pandemia global, causada pe SarsCov2, que impossibilitou o evento presencial, o encontro toi realizado virfualmente em novembro de 2020 e uma segunda edição está prevista para novembro de 2021.

21 Entendemos que a Economia de Francisco é resultado de um processo iniciado pelo Papa desde o inicio do seu Pontificado. Buscando aprofundamento.

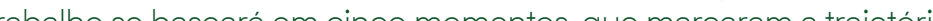
de Bergoglio como Francisco e que segundo Raupp e Susin (2021) se constituem como fios de ouro para entender a economia segundo Francisco, sendo: a Exortaç̃o Apostólica Evangelii gaudium, os encontros com os movimentos populares. ancílica Loudato si, o chamado pas o evento, e a Enciclica Frotelli Tuti.

22 A exortação apostólica Evangelii gaudium, que significa "A Alegria do Evangelho", foi publicada em 2013, primeiro ano do Pontificado de Papa Francisco, sendo considerada o programa do seu pontificado. Na introdução. Francisco já demonstra suas intenções com esse documento: "Quero com essa Exortação, dirigir-me aos fiéis cristãos a fim de os convidar para uma nova etapa evangelizadora marcada por esta alegria e indicar caminhos para o percurso da Igreja nos próximos anos" (FRANCISCO, 2013, p. 3).
Viver como cultura, já que esta é uma importante chave de leitura para o Papa Francisco que vem da Teologia do Povo ou da Cultura, ${ }^{23}$ no sentido da urgência da mudança no atual estilo de vida, dos modelos de produção e consumo. Na EG, o Papa fala "não a uma economia da exclusão", ${ }^{24}$ visto que ao excluir fere-se o sentimento de pertença à sociedade, sendo que para apoiar esse estilo de vida excludente desenvolve-se uma globalização da indiferença, uma cultura do descarte. Contra isso, é preciso construir uma cultura do encontro, aberta ao diálogo e à reconciliação. Na Laudato $\mathrm{Si}^{\prime}{ }^{25}$ demonstra que a construção dessa cultura do encontro que requer uma nova educação

23 Segundo Scannone (2016, 2017), a Teologia del Pluebo é considerada uma vertente argentina da teologia latino-americana.

24 No capitulo 2 da Evangelium Gaudium, Na crise do compromisso comunitário, fundamental para o entendimento da Economia de Francisco, o Papa Francisco (2013) fala dos quatro "não", a saber: (1) Não a uma economia da exclusão: as extremas desigualdades sociais tem uma raiz econômica. Economia que além de matar, é pautada pela "lei do mais forte" e como consequência grande parcela da sociedade é excluida e marginalizada. (2) Não à nova idolatria do dinheiro: a presente crise financeira faz esquecer que, na sua origem, há uma crise antropológica. Esse sistema econômico nega a primazia do ser humano, pois considera o ser humano como bem de consumo. Portanto, a crise mundial demonstra os desequilibrios desse sistema, em que se tem um fetichismo do dinheiro e uma economia sem rosto e sem objetivo verdadeiramente humano, sem uma orientação antropológica. (3) Não a um dinheiro que governa em vez de servir: esse modelo econômico rejeita a etica, pois ela permitiria criar um equilibrio e uma ordem social mais humana. Papa Francisco cita um sábio da antiguidade São João Crisostomo: "não azer os pobres participar dos seus proprios bens e roubá-los e tirar-thes a vida. Náo sáo nossos, mas deles, os bens que aferrolhamos." Assim, faz um propicia do ser humano. (4) Não à desigualdade social que gera violencia: propicia do ser humani. (4) Nào à desigualdade social que gera violencia. enquanto náo se eliminar a exclusão a a desigualdade da sociedade será inpossivel desarrelgar a violexcia. Náo há programas polticos ou foças da

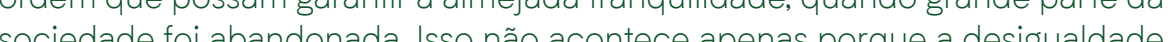
social gera reacão violenta dos excluidos do sistema mas porque o sistema social gera reaça vio lenta dos excludidos do sistema, mas porque o sistema desigualdade social e não são as armas a solução para esse drama sociel.

25 A carta encíclica Laudato Si', foi publicada em 2015, e seu nome significa: Louvado sejas, meu Senhor, inspirado Cântico das Criaturas de São Francisco de Assis (FRANCISCO, 2015a). Com uma relação de cuidado e afeto com a casa comum, Francisco de Assis chamava a tudo e a todos como irmão e irmã. Assim, com essa enciclica, Francisco de Roma pretendeu estabelecer um diálogo com todos acerca da nossa casa comum. Apresentou a problemática ecológica como uma crise que é consequência dramática das atividades descontroladas do ser humano, ou seja, a crise ecológica tem uma aiz humana, já que tudo está intimamente interligado. 
(uma nova educação para uma nova economia) ${ }^{26}$ e espiritualidade, baseada na mística do Bem Comum. ${ }^{27}$

Viver como pacto, esse foi o convite feito na carta de 2019 ao escrever "estabelecer um pacto para mudar a economia atual atribuir uma alma à economia de amanhã” (FRANCISCO, 2019 $\mathrm{s} / \mathrm{p}$.). Na mensagem de 2020 reforçou a necessidade desse pacto afim de construir um modelo de desenvolvimento socioeconômico a serviço de todos, sem exceção, que promova paz e justiça social, bem como cuidado com a Mãe Terra. Segundo Raupp:

Não há como firmar esse pacto sem visão global, ainda que a ação predominante seja aquela ao alcance dos pés e das mãos, que é local Logo o próprio processo da Economia de Francisco se desenrola descle antes ( (RAUPP; SUSIN, 2O21, p. 208)

26 Em setembro de 2019, o Papa Francisco fez um convite para um Pacto Global na Educação, pois segundo ele "educar é um ato de esperança". 0 evento presencial ocorreria em maio de 2020 (Roma, Itália), mas também fo cendo de forma vitual. Para saber mas, ver: https //wm estä acontecompact.org/

27 A politica econômica deveria ser estruturada a partir do bem comum. As ações assistencialistas são importantes porque dão respostas às emergências atuais, mas devem ser entendidas como respostas provisórias. As desigualdades sociais devem ser radicalmente solucionadas, a partir da renúncia da autonomia absoluta dos mercados e da especulação financeira, atacando assim as causas estruturais que têm raizes econômicas. E para o Papa Francisco o autor principal, ou seja, o sujeito histórico desse processo é a gente e a sua cultura, pois, como dito, Francisco vem da Teologia do Povo. Não é um grupo ou uma classe especifica, pois dessa maneira seria um projeto de pouco para poucos. Não é um projeto de uma minoria esclarecida que se aproprie do sentido coletivo. E um projeto que vem da base, de todos, a partir de um acordo para viver o espirito de comunidade, do bem comum, que ele chama de um pacto social e cultura.
Na Fratelli Tutti, ${ }^{28}$ escreve: "quando se trata de recomeçar, sempre há de ser a partir dos últimos" (FRANCISCO, 2020b, p. 169), escreve , já que a opção pelos últimos é optar "por aqueles que a sociedade descarta e lança fora" (FRANCISCO, 2013, p. 161). É recomeçar debaixo, a partir dos sabores e saberes locais, de maneira que "não pensemos por eles, pensemos com [...] e deles aprendamos a fazer progredir modelos econômicos que beneficiem todos" (FRANCISCO, 2O2Oa, s/p.). Isso significa exercitar uma escuta séria e respeitosa da voz daqueles que estão nas periferias do mundo e da existência e que por tantos anos foram silenciados, criminalizados, perseguidos, quando na verdade estavam (e ainda estão) em busca de um mundo melhor.

Esse movimento de ir ao encontro e escutar faz parte da postura do Papa Francisco, mesmo antes de se tornar o Bispo de Roma. Nos primeiros anos do seu pontificado realizou três importantes encontros com os movimentos populares: Roma (2014, 2016) e Santa Cruz de La Sierra (2015b). ${ }^{29}$

No discurso de (2014), o Papa Francisco reforça que a solidariedade, tão presente nos movimentos populares, não deve ser entendida como gesto esporádico, mas com imenso potencial

28 A carta encíclica Fratelli Tutti foi publicada em em 04 de outubro de 2020, dia de São Francisco de Assis, e significa Todos Irmãos, em referência a um poema medieval de mesmo nome atribuido ao Santo de Assis (FRANCISCO, 2020b). Com enfoque franciscano, a enciclica traz como tema a fraimpade co ho vár central das relaçoes a par tr da cullura do encontro e a imps mulcumanos no periodo das Cruzadas.

29 Durante a pandemia o Papa Francisco escreveu uma carta aos movimentos populares referindo-se a esses três encontros e encorajando-os a enfrentar as dificuldades, assim como sempre fizeram "arregaçando as mangas" para trabalhar em prol das suas familias, seus bairros, para o bem comum, em suas palavras: "Lembro-me com frequência de nossos encontros: dois no Vaticano e um em Santa Cruz de la Sierra e confesso que essa "memória" me faz bem, me aproxima de vocês, me faz repensar em tantos diálogos durante esses encontros e em tantas esperanças que ali nasceram e cresceram e muitas delas se tornaram realidade. Agora, no meio dessa pandemia, eu me lembro de vocês de uma maneira especial e quero estar perto de vocês. Nestes dias de fanta angústia e dificuldade, muitos se referiram à pandemia que sofremos com metáforas bélicas. Se a luta contra o COVID-19 é uma guerra, vocês são um verdadeiro exército invisível que luta nas trincheiras mais perigosas. Um exército sem outra arma senão a solidariedade, a esperança e o sentido da comunidade que reverdece nos dias de hoje em que ninguém se salva sozinho. Vocês são para mim, como thes disse em nossas reuniões, verdadeiros poetas sociais, que desde as periferias esquecidas criam soluçoes dignas para os problemas mais prementes dos excluidos" (FRANCISCO, 2020c, s/p.). 
para resultar em ações concretas e transformadoras, já que em um mundo da indiferença por si só é transgressora e revolucionária. Solidariedade que faz lutar contra as causas estruturais da pobreza, que reconhece a função social da propriedade o destino universal dos bens como realidades anteriores à propriedade privada. ${ }^{30}$ Solidariedade que supõe a criação de uma nova mentalidade que pense em termos de comunidade, colocando a vida como prioridade e não a apropriação dos bens por parte de alguns.

A solidariedade é uma reação espontânea de quem reconhece a função social da propriedade e o destino comum universal dos bens como realidades anteriores à propriedade privada A posse privada dos bens justifica-se para cuidar deles da. A posse priv da do bervirem melhor o bem comumies aumentálos de modo a servirem melhor o bem comum, pelo que a solidariedade deve ser vivida como a decisão de desenvolver ao po práticas de solidariedade, quando se fazem carne, abrem

30 O Destino Universal dos Bens afirma que Deus criou o mundo e todas as alsas para salistazer a necessidade de todos, sem excecăo. Recon hece-se dinada ao princípio da Destinação Universal dos Bens, bem como a funcão social de qualquer forma de posse privada. Esse principio está presente na Doutrina Social da lgreja, sendo que o parágrafo 172 diz: "O principio da destinação universal dos bens da terra está na base do direito universal ao uso dos bens." Todo o homem deve ter a possibilidade de usufruir do bem-esta necessário para o seu pleno desenvolvimento: o principio do uso comum do bens é o "primeiro principio de toda a ordem ético-social" e "principio tipico da doutrina social cristã." Por esła razão a lgreja considerou necessário precisar-Ihe a natureza e as características. Trata-se, antes de tudo, de um direito natural, inscrito na natureza do homem e não de um direito somente positivo. ligado à contingência histórica; ademais, tal direito é originário. É inerente pessoa singularmente considerada, a cada pessoa, e é prioritário em relação a qualquer intervenção humana sobre os bens, a qualquer regulamentação juridica dos mesmos, a qualquer sistema e método econômico-social: "Todos os outros direitos, quaisquer que sejam, incluindo os de propriedade e de comércio livre, estão-Ihe subordinados [à destinação universal dos bens]: não devem portanto impedir, mas, pelo contrário, facilitar a sua realização; e é um dever social grave e urgente conduzi-los à sua finalidade primeira" (PONTIFiCIO CONSELHO JUSTIÇA E PAZ, 2004 s/p). Andrade (2021) resgata esse principio desde sua origem até atualmente, já que segundo ele: "a questão da Propriedade dos Bens sempre possuiu um lugar importante no Ensino Socia da Igreja, da Patrística aos nossos dias. Na moderna Doutrina Social da Igreja. de Leão XIII a Francisco este tema possui um rico desenvolvimento que, de um lado se mantém fiel ao princípio da Destinação Universal dos Bens que se encontra no ensinamento dos Padres da Igreja desde os primeiros séculos do Cristianismo e, de outro, acrescenta novas dimensões a este princípio, como a dimensão ecológica e intergeracional, isto é, o dever da atual geração de garantir que as futuras gerações possam ter pleno acesso aos bens criados por Deus, de modo a garantir a vida e a satisfação das necessidades de todos os humanos, de hoje e de amanhã" (ANDRADE, 2021, p. 69). caminho a outras transformações estruturais e tornam-nas possiveis. Uma mudança nas estruturas, sem se gerar novas conviccões e atitudes, fará com que essas mesmas estruturas, mais cedo ou mais tarde, se tornem corruptas, pesadas ineficazes (FRANCISCO 2013, 156).

no discurso de 2015 , vincula as causas estruturais da pobreza em relação direta às causas econômicas. Demonstra como a desigualdade e a injustiça social são resultado de uma prévia opção social de um sistema econômico que idolatra o dinheiro. E no discurso de 2016, expressa a revolta presente na doutrina da Igreja com a forma abusiva do sistema econômico perante a sociedade: "Toda a doutrina social da lgreja e o magistério dos meus predecessores estão revoltados contra o ídolo dinheiro, que reina em vez de servir, tiraniza e aterroriza a humanidade" (FRANCISCO, 2016, s/p.).

Nesse sentido, os movimentos populares já trilham um caminho revolucionário, pois a partir das suas práticas solidárias, que emergem do chão que pisam, são exemplos de resistência e mobilização popular. São referências para a Economia de Francisco porque aspiram mudanças estruturais, para além das demandas imediatas, uma vez que:

[...] os movimentos querem pão para hoje, mas não fome para amanhã: temos reivindicações imediatas, mas também uma utopia a propor, que contempla a reforma agrária, a integração urbana e a inclusão pelo trabalho. Marchamos por uma sociedade sem escravos nem excluidos, com terra, teto e trabalho para todos (GRABOIS, 2016, s/p.).

O Papa reforça que é preciso pensar em um projeto de desenvolvimento integral, focado no protagonismo dos povos em toda sua diversidade, garantindo assim o acesso universal aos três T: terra, teto e trabalho, bandeira de luta dos movimentos populares. No Quadro 1.1, Raupp (2021) elabora uma síntese dos momentos e categorias do pontificado de Francisco sobre a economia.

Dessa maneira, vejo assim minha possível contribuição para o movimento, já que a busca pelo direito à cidade, presente nas lutas sociais engendradas pelos moradores de ocupações, é uma tentativa de encontrar ao menos brechas emancipatórios desse sistema econômico, e representam desafios permanentes de ação e de reflexão. Acredito que a reflexão incentivada pelo Papa Francisco ao realizar esse chamado para uma nova economia se conecta à produção do espaço urbano porque é na cidade que se coloca de maneira mais intensa o impasse da contradição de uma sociedade que se organiza com a 
lógica mercantil, com a mercantilização das relações sociais. Assim, inserir a questão urbana no debate sobre economia é uma tarefa nossa, arquitetos e urbanistas, já que para Maricato

\section{Evangelii gaudium:} a economia no programa de um seu olhar sobre a

de exclusão e desigualdade (uma economia que matal

Necessidade de uma nova narrativa econômica que tenha por base uma orientação antropologica que não reduza o ser humano (humanismo integral); a cultura do encontro

Dinamismo de saída da Igreja, e seu correspondente caráter missionário

Encontros com os movimentos

populares:

A terra, o teto e o trabalho (os 3 “T”s) são necessidades básicas da vida humana e direitos sagrados pelos quais se deve lutar

a economia a partir

das periferias da

existência

Pôr a economia a serviço dos povos, e desde as periferias da existência (os pobres como lugar teológico de partida)

Questionar a subjugação dos povos pelo que se chama de colonialismo ideológico globalizador

Laudato si': uma nova economi que surge de uma

ecologia integra

Vivemos uma só crise sócio-ambiental, a qual contempla economia e pede outras maneiras de entendê-la

A politica não deve submeter-se à economia, e esta não da tecnocracia a dizer, do modo capitista neolibera

O bem comum, que é o principio número um da DS desempenha um papel central e unificador na efica social. e apresenta-se como uma noção inseparável da ecologia integral

\begin{tabular}{|c|c|}
\hline \multirow{3}{*}{$\begin{array}{l}\text { O chamado para } \\
\text { a Economia de } \\
\text { Francisco: } \\
\text { um pacto para realmar } \\
\text { a economia }\end{array}$} & Realmar uma economia visivelmente em ruinas \\
\hline & $\begin{array}{l}\text { Quatro principios fundamentais que, antes de ser eleito Papa, } \\
\text { o Cardeal Bergoglio já explicitava como necessários a um } \\
\text { povo na construção de um projeto comum:o tempo é superior } \\
\text { ao espaço, a unidade é superior ao conflito, a realidade é } \\
\text { superior à ideia, e o todo é superior à parte. }\end{array}$ \\
\hline & $\begin{array}{l}\text { Tratar continuamente as causas estruturais das disfunções da } \\
\text { economia mundial; realizar um novo e grande pacto; visão } \\
\text { global e ação local; construção processual (Economia de } \\
\text { Francisco acontece desde antes e para além do evento) }\end{array}$ \\
\hline \multirow[t]{3}{*}{$\begin{array}{l}\text { Fratelli tutti: } \\
\text { uma nova economia } \\
\text { em que todos e todas } \\
\text { sejamos irmãos e } \\
\text { irmãs }\end{array}$} & $\begin{array}{l}\text { O neoliberalismo é um "dogma de fé" baseado num } \\
\text { pensamento pobre, repetitivo, que propõe sempre as mesmas } \\
\text { receitas perante qualquer desafio que surja em sua mágica } \\
\text { teoria "trickle-down economics" }\end{array}$ \\
\hline & $\begin{array}{l}\text { A lógica de dominus (senhorio) precisa ser substituida pela de } \\
\text { frater (fraternidade universal), o que também permite rever a } \\
\text { própria noçãa de domínio (como senhorio de amor e serviço) }\end{array}$ \\
\hline & $\begin{array}{l}\text { Desenvolvimento humano integral como principio balizador da } \\
\text { nova economia }\end{array}$ \\
\hline
\end{tabular}

FONTE: Raupp (2021).
(2019) não basta distribuir renda ou acesso à moradia, é preciso "distribuir cidade", entendendo que o direito à cidade passa pela reforma fundiária e imobiliária. Para alcançar a tão falada democratização da cidade é necessário antes uma democratização econômica, e nesse sentido urge a necessidade de uma nova economia.

\subsection{CIDADE PRODUZ OCUPAÇÃO: LIMITES}

Dizer que a cidade produz ocupação significa que a pesquisa parte do reconhecimento de que a forma ocupação pode, por um lado, ser entendida como resultado da precarização gerada pelo capitalismo, reflexão endossada ao participar da Economia de Francisco. A partir da identificação da raiz econômica das desigualdades socioterritoriais, é possível dizer que as ocupações urbanas revelam os limites e contradições de uma sociedade que se organiza a partir de uma lógica capitalista. O urbano tem uma relação muito influenciada pelo sistema econômico, pois a cidade não é somente locus da produção, mas, no modo de produção capitalista, é também mercadoria que se transforma em capital. Assim, a cidade, nesta parte da reflexão, é definida a partir da concepção de Maricato (2001), como produto de interesses em disputa, arbitrados pelo Estado, e dependente da correlação de forças de uma sociedade capitalista periférica.

A cidade, enquanto mercadoria, em que o valor de uso de um bem comum como a terra foi dominado pelo valor de troca em lógica capitalista, fez (e ainda faz) com que houvesse uma disputa de forças pelas localizações. ${ }^{31}$ Assim, são os territórios que não interessam ao mercado imobiliário os que restam para a população de baixa renda. Nesse sentido, a terra

31 "Como mostra Flávio Villaça, a noção de segregação diz respeito a uma relação entre localidades e a cidade. Não é uma relação física dada pelas escalas de distância e proximidade, tal como se poderia medir no mapa da cidade. E uma relação social que diz respeito à dinâmica da cidade, aos modos como a riqueza é distribuida (e disputada) e corporificada nas suas materialidades, formas e artefatos, definindo as condiçoes desiguais de acesso a seus espaços, bens e serviços" (TELLES et al., 2006, p. 76, grifo da autora). 
passa a ser dominada por um mercado restrito, elitista e especulativo (MARICATO, 2011).

No Brasil, desde a Lei de Terras (1850), a relação entre a sociedade e o território ocupado se dá através de uma forma específica de vínculo, de uso e de direito sobre a terra, que é a propriedade individual registrada. ${ }^{32} \mathrm{~A}$ questão fundiária, portanto, está no cerne da produção do espaço desigual das cidades brasileiras. Maricato (2013a) aponta que a propriedade da terra continua a ser o "nó" na sociedade brasileira, já que a dificuldade de acesso à terra para habitação pela população de baixa renda é o responsável pelo crescimento das ocupações urbanas. Afirma ainda que o processo de urbanização brasileira é marcado pela herança dos conflitos sociais que caracterizaram o século XIX e revela a relação que articula o acesso à terra com a mão de obra e a colonização, portanto, a forte correlação entre a propriedade privada da terra (o cativeiro da terra) com a libertação dos escravos (o cativeiro do trabalho) (MARICATO, 2013a). ${ }^{33}$

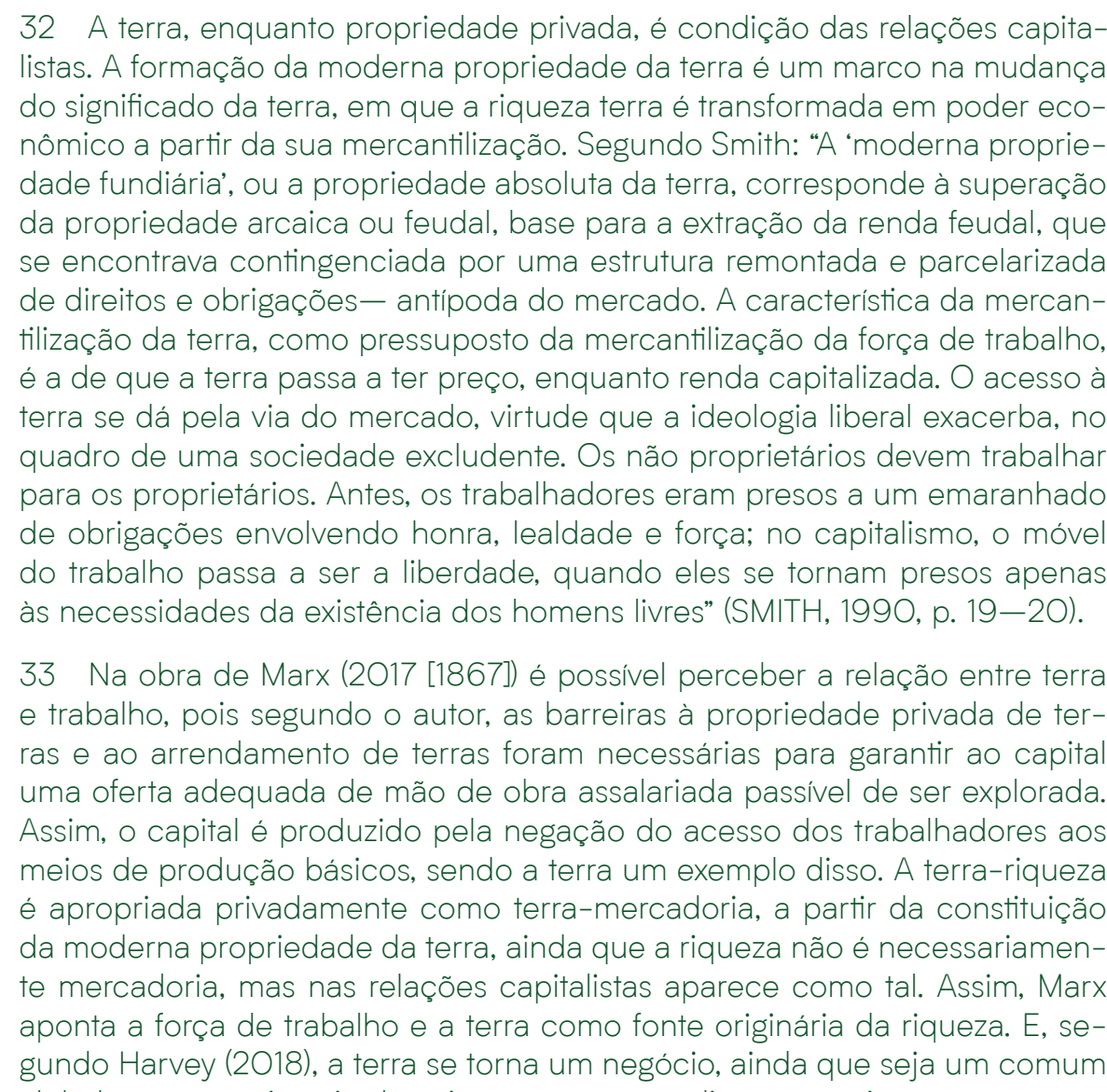

Sendo assim, a concentração de terras nas mãos de poucos foi (e continua) sendo um entrave para a democratização das cidades, o que faz com que a grande maioria da população não tenha acesso à terra de maneira justa e adequada. A ocupação de terras urbanas, portanto, não é algo recente, mas é parte intrínseca do processo de urbanização brasileiro que segrega e exclui. A ocupação se dá por falta de alternativa e não por vontade dos ocupantes de confrontar a lei, como muito se difunde. $\mathrm{Na}$ realidade, as ocupações são resultado de um processo estrutural e institucionalizado pelo mercado imobiliário excludente e pela ausência de políticas públicas efetivas (MARICATO, 2013a).

Bolaffi (1982 [1975]) demonstra que a construção desigual das cidades está inserida em processos econômicos e políticos. Segundo o autor, o solo urbano deixou de significar apenas uma utilidade e transformou-se em um objeto de ações econômicas, alheio ao seu valor de uso. Assim, o poder público deveria adquirir meios reais e efetivos para controlar o uso do solo, pois a política fundiária brasileira é a ausência de impostos significativos sobre a propriedade imobiliária, trazendo como consequência cidades cada vez mais descapitalizadas e empobrecidas. O problema é que esse empobrecimento e deterioração das cidades são apresentados como sendo um processo orgânico de envelhecimento natural ou de crescimento excessivo e não como consequência direta da economia política vigente. Para ele a solução estaria na reformulação da política tributária urbana:

As cidades não são formadas por células vivas, mas por propriedades privadas e por serviços públicos [...] e um processo econômico. Mas quando o Estado não arrecada os recursos necessários para que os serviços públicos cresçam proporcionalmente às propriedades privadas 0 processo é político (BOLAFFI, 1982 [1975], p. 67-68).

Principalmente a partir de 1960, com a crescente migração rural-urbana, a autoprodução foi a solução possível que a população de baixa renda encontrou diante da insuficiência de meios e da exclusão do mercado imobiliário privado. Como aponta Maricato (2003), os trabalhadores são excluídos desse mercado, trata-se do "produtivo excluído", resultado da industrialização com baixos salários. Tal forma de produção do espaço foi tolerada pelo Estado e sociedade já que foi importante para a expansão do capitalismo periférico, uma vez que o autofinanciamento das habitações permitiu o rebaixamento do custo de reprodução da força de trabalho e, como conceitua 
Maricato (2013), de uma urbanização com baixos salários. A autora expressa que

A ilegalidade na provisão de grande parte das moradias urbanas (expediente de subsistencia e não mercadoria capitalista) é funcional para a manutenção do baixo custo de reprodução da força de trabalho, como também para um mercado imobiliário especulativo (ao qual correspondem relações de trabalho atrasadas na construcão), que se sustenta sobre a estrutura fundiária arcaica (MARICATO, 2013a, p. 147-148).

Nesse sentido, a autoconstrução das moradias pela população de baixa renda está atrelada ao modelo brasileiro de desenvolvimento "desigual e combinado", produto da acumulação capitalista, já que "a expansão do capitalismo no Brasil se dá introduzindo relações novas no arcaico e reproduzindo relações arcaicas no novo" (OLIVEIRA, 2003 [1972], p. 60). ${ }^{34}$ O Estado não amparou ou garantiu condições mínimas para a concentração de trabalhadores da indústria nas cidades em formação, o que colaborou para a precarização das condições de vida em moradias. O trinômio loteamento popular- casa própria - autoconstrução foi a forma predominante da produção de moradia a partir das mãos da classe trabalhadora (MAUTNER, 1999).

As pesquisas iniciadas nos anos 1970 ampliaram esse debate à medida que demonstraram que ao invés dos moradores de favela estarem em um processo de ascensão social, estariam em processo de empobrecimento. Estudos pioneiros, como os de Pasternak-Taschner (1978) e Kowarick (1980) para São Paulo, foram fundamentais para uma revisão da concepção que se tinha até então do lugar da moradia precária no processo de adaptação de migrantes à cidade. Esses estudos expuseram o

34 O autor continua: "[...] um modo de compatibilizar a acumulação global, em que a introdução das relações novas no arcaico libera força de trabalho que suporta a acumulação industrial-urbana e em que a reprodução de relações arcaicas no novo preserva o potencial de acumulação liberado exclusivamente para os fins de expansão do próprio novo. Essa forma parece absolutamente necessaria ao sistema em sua expressão concreta no Brasil, quando se opera uma transição tão radical de uma situação em que a realização da acumulação dependia quase integralmente do setor externo. para uma situação em que será a gravitação do setor interno o ponto crítico da realização, da permanência e da expansão dele mesmo. Nas condições concretas descritas, o sistema caminhou inexoravelmente para uma concen tração da renda, da propriedade e do poder , em que as próprias medidas de intenção corretiva ou redistributivista - como querem alguns - transformaram-se no pesadelo prometeico da recriação ampliada das tendências que se queria corrigir” (OLIVEIRA, 2003 [1972], p. 60). papel da massa trabalhadora na economia nacional e de sua inegração, mesmo que subordinada. Romperam com a visão dominante até aquele momento do morador de ocupação como migrante rural, que estaria em um processo de ascensão social no meio urbano. Na realidade, "parte significativa dessa população não era composta de migrantes em processo de ascensão social, mas sim de camadas empobrecidas, em processo de mobilidade social descendente" (CARDOSO, 2007, p. 222).

O modelo de desenvolvimento brasileiro, portanto, sempre associou um grau de crescimento econômico a uma desigualdade extrema, confirmada pelo fato de que parte da população está situada abaixo da linha da pobreza. A pobreza e a desigualdade, portanto, são características estruturais que acompanham o desenvolvimento brasileiro e estão associadas a um processo crescente de precarização e informalização das relações de trabalho (CARDOSO, 2007).

Processo agravado a partir dos anos 1980 e 1990 com o avanço da nova razão do mundo, ou seja, do estágio do capitalismo neoliberal. ${ }^{35}$ Segundo Harvey (2O18), essa nova ordem quebrou - Estado-providência (que deu lugar ao Estado-neoliberal), a organização sindical, a noção de pleno emprego, a certeza do individual e familiar sobre o futuro, desencadeando uma reestruturação produtiva com significativas mudanças no mundo do trabalho.

Já de acordo com Dardot e Laval (2016), o neoliberalismo pode ser entendido como a universalização da razão capitalista que avança sobre toda a existência humana, de todas as formas sociais, de maneira que se redefine a forma como se vive, pensa e sente o mundo. Os autores identificam ao menos três aspectos da racionalidade neoliberal, a saber: "a degradação social e econômica da posição dos dominados, resultantes da lógica ao mesmo tempo competitiva e desigual do capitalismo neoliberal; a degradação acelerada do meio ambiente; a degradação da via política democrática” (BARROS; DAL'BO DA COSTA; RIZEK, 2018, p. 164).

35 Nos paises "centrais" o neoliberalismo já havia ganhado força desde a década anterior, através dos governos de M. Thatcher, na Inglaterra (19791990) e no segundo governo Reagan nos Estados Unidos (1985-1989). Segundo Dal'Bó da Costa, o neoliberalismo e uma "razão politica" que tem a capacidade de se moldar a diferentes ideologias, "seja no espectro de esquerda ou direita, seja nos Estados democráticos liberais ou nacionalistas conservadores" (2019, p. 203). 
Dal'Bó da Costa (2019) busca compreender a emergência de uma forma específica da produção do espaço decorrente da generalidade da racionalidade neoliberal, o que nomeia como a produção neoliberal do espaço. Para ele, a produção atual das cidades inseridas nesse estágio tem uma grande capacidade de incorporar práticas existentes, inclusive aquelas que a princípio não visavam acumulação, mas que ao serem incorporadas são transformadas e passam a fazer parte das rotinas de acumulação.

Exemplo disso é a incorporação e transformação da rotina de resistência dos movimentos de moradia quando inseridos no Programa Minha Casa Minha Vida (MCMV), em sua modalidade Entidades, passando a competir pela aprovação de projetos por repasses de verba. Para o autor, o MCMV pode ser entendido como dispositivo neoliberal do qual resulta uma produção neoliberal do espaço que contribui para a manutenção da acumulação privada, inclusive as grandes construtoras brasileiras, combinando uma falsa imagem de ampliação de direitos por meio do acesso à moradia que, em grande, parte está mal localizada (em áreas sem infraestrutura e de difícil acesso) e é de baixa qualidade arquitetônica.

Em resumo, o MCMV foi capaz de criar, por um lado, condições inéditas de acumulação ao setor da construção civil, criando também empregos no período onde já se sentia os efeitos da crise financeira internacional e, por outro lado, incorporar e transformar a rotina de resistência dos movimentos de luta por moradia em seu funcionamento, fazendo-os gestores do próprio programa, e colocando-os em concorrência entre os próprios movimentos de moradia, para finalmente transformá-los em gestores e mediadores dos riscos de insurgência popular e não mais o próprios produtores das insurgências populares. Tudo isso resultará em produco espaço e cidades que serão genuinamente produtos da razâo

Sobre essa questão da localização dos empreendimentos, Rodrigues (2013) afirma que a ausência de política fundiária, combinada à grande quantidade de recursos públicos e privados disponiveis para o setor da construção civil e a financeirização da produção da moradia e da cidade fazem com que a busca por áreas disponiveis para a produção habitacional de interesse social seja cada vez mais difícil. Segundo a autora, o MCMV é fruto da trajetória de mobilização e de pressão dos movimentos populares, mas que ao ser posto em prática é possíve constatar o conflito entre a proposta política autogestionária, bandeira de luta dos movimentos, e as condições estabelecidas pelas políticas de habitação e solo urbano. Nesse sentido, é possivel afirmar que o Programa consagra um modelo de produção habitacional baseado em um único modo de acesso à moradia, que é a partir da aquisição da propriedade individual da casa, tornando-se, assim, um produto de mercado, sendo que $o$ aparato normativo é perfeitamente adequado para esse objetivo (RODRIGUES, 2013).

Ainda segundo Dal'Bó da Costa (2019), da produção neoliberal do espaço decorrem duas noções: a primeira é a persistente e contínua interação entre, nos termos de Oliveira (2003 [1972]), o arcaico e o moderno, que no Brasil coexistem em perfeita desarmonia produtiva. Nesse sentido, os setores considerados "avançados", que se apoiam no capital financeiro internacional e na herança oligárquica e escravocrata da história de formação brasileira, possuem uma relação de interdependência e de interação produtiva com os setores tidos como "atrasados" da sociedade.

A segunda noção, como já exposto, decorre do entendimento do neoliberalismo como racionalidade política e, nesse sentido, teria avançado sobre todos os domínios da existência humana, produzindo cada vez mais sociedades e cidades sob o imperativo da mercantilização e da privatização de todos os bens essenciais à vida e de todos os espaços, impactando inclusive as relações sociais.

Como explica Oliveira (2003 [1972]), não se trata de exclusão, afinal todos estão incluídos, ainda que de maneira desigual. Nesse sentido, é possível dizer que riqueza, desemprego, miséria e herança colonial fazem parte da constituição da nossa sociedade, resultante de um processo histórico sem rupturas radicais nas bases sociais (OLIVEIRA, 2003 [1972]). Com a nova razão de mundo, as desigualdades passam a ser ainda mais abissais, já que crescimento econômico e concentração cada vez maior de renda e riqueza são apresentados como intocáveis e como sendo a única alternativa possível para a constituição das sociedades e da produção das cidades.

Portanto, dizer que cidade produz ocupação é reconhecer que a "generalização do sistema capitalista produz inexoravelmente desigualdades socioeconômicas, exploração e assimetrias nas condições de apropriação do espaço" (SANTO AMORE; LEI- 
TÃO, 2019, p. 19). É limite porque as periferias, ainda que a princípio possam ser consideradas uma forma de resistência a esse sistema injusto a partir da luta pelo direito à cidade, (re) produzem um espaço considerado como fronteira de expansão do capital (MAUTNER, 1999).

\subsection{OCUPAÇÃO PRODUZ CIDADE: POTENCIALIDADES}

O verdadeiro fundador da sociedade civil foi o primeiro que, fendo cercado um terreno, lembrou-se de dizer isto é meu encontrou pessoas suficientemente simples para acreditá-lo. Quantos crimes, guerras, assassínios, misérias e horrores não pouparia ao gênero humano aquele que, arrancando as espouparia ao genero humano aquele que, arrancando as esfacas ou enchendo o fosso, tivesse gritado a seus semelhantes: 'Defendei-vos de ouvir esse impostor; estareis perdidos se esquecerdes que os frutos são de todos e que a terra não pertence a ninguém!' (ROUSSEAU, 1997, p. 87).

Dizer que ocupação produz cidade é procurar avançar na reflexão para além dos limites impostos por essa forma de produção do espaço, inserida no modo de produção capitalista a fim de refletir sobre potencialidades transformadoras, ou seja, investigar caminhos emancipatórios (ou ao menos brechas possíveis) que se contrapõem à mercantilização de bens essenciais à vida.

Essa conceituação parte do pressuposto da ocupação como resistência à produção do espaço pelo capital, onde a apropriação da terra sobrepõe o valor de uso ao valor de troca, pelo menos a princípio. Nesse sentido, a produção do espaço urbano é entendida de forma indissociável da apropriação que se faz desses territórios (ROSA, 2008).

O conceito de apropriação trabalhado ao longo da pesquisa tem como referência a obra de Lefebvre $(2002,2006)$, onde o autor traz a ideia de apropriação em contraposição ao conceito de propriedade privada. Segundo ele, a propriedade é um ato de possessão, de desvio das atividades apropriativas (do tempo, do espaço, do corpo, do desejo), que busca atender às necessidades. Já a apropriação (individual ou coletiva e não a privada) é evidenciada como expressão do uso, sendo este o movimento contrário à forma mercadoria.
Ainda para Lefebvre (2002, 2006), a propriedade privada expressa o valor de troca, a geração de valor, a quantificacão, os espaços comprados e vendidos, o consumo produtivo, seja do espaço, do tempo e/ou do corpo para auferir lucro e rentabilidade. A propriedade privada acarreta privação, apossar-se com dominação, de uma riqueza comum como a terra, tão essencial à vida. Isso implica em poder e controle social, à medida que sustenta e intensifica a acumulação da riqueza comum.

No modo de produção capitalista, a moderna propriedade da terra se refere a uma forma de restrição à verdadeira apropriação, pois segundo Lefebvre a propriedade privada da terra simula e caricatura a apropriação, levando à destruição. Ele também diferencia espaços dominados de espaços apropriados:

Hoje, se impõe a distinção, que Marx não introduziu, entre a dominação e a apropriação da natureza. A dominação pela técnica tende para a não apropriação: a destruição. Isto não quer dizer que esta destruição siga inevitavelmente seu curso, mas que há conflito entre a dominação e a apropriação. Este conflito se desenrola no espaço. Há espaços dominados e espaços apropriados (LEFEBVRE, 2006, p. 465).

Já a apropriação refere-se ao uso que se opõe ao valor de troca e à produção de mais-valia, às qualidades, ao consumo improdutivo, à festa em prol do prazer, à existência. Esses processos apropriativos, nos quais a forma ocupação está inclusa, representam resistência a uma sociedade baseada na moderna propriedade da terra, passando o valor de uso a dominar o valor de troca, e daí advém potência transformadora da ocupação:

Trata-se de uma superação pela e na prática: trata-se de uma mudança de prática social. O valor de uso, subordinado ao valor de troca durante séculos, pode retomar ao primeiro plano. Como? Pela e na sociedade urbana, partindo dessa realidade que ainda resiste e que conserva para nós a imagem do valor de uso: a cidade. Que a realidade urbana esteja destinada aos "usuários" e não aos especuladores, aos promotores capitalistas, aos planos dos técnicos, é uma versão justa, porém enfraquecida desta verdade (LEFEBVRE, 2001, p. 127)

Assim, o ato de ocupar revela que "a terra não é de ninguém", já que é sempre bem comum, seja como natureza ou espaço 
socialmente produzido, ideia que converge com o princípio da Destinação Universal dos Bens, como também com o chamado para a Economia de Francisco. É nesse sentido que a ocupação é colocada enquanto uma forma de produção do espaço urbano, que contém o duplo movimento conflituoso entre valor de uso e valor de troca, mas que nesse sentido o valor de uso domina, mesmo que em princípio, o valor de troca. Domina porque valor de uso corresponde à necessidade, à expectativa e à desejabilidade. $O$ reconhecimento da terra enquanto bem comum, em contraposição à visão de bem de consumo, portanto como poder econômico, é uma tentativa de fortalecer práticas e lutas cotidianas daqueles que buscam formas apropriativas da terra baseadas na defesa da vida e do direito à cidade. E Lefebvre coloca o direito à apropriação como algo inerente ao direito à cidade:

direito à cidade se manifesta como forma superior dos direios: direito à liberdade, à individualização na socialização, ao habitat e ao habitar. O direito à obra (à atividade participante) o direito à apropriação (bem distinto do direito à proprieda134, grifos do autor).

Harvey (2013) concorda com Lefebvre ao insistir que a revolução tem de ser urbana, uma vez que o processo urbano é visto como um negócio lucrativo, sobretudo com o neoliberalismo no qual há a privatização de tudo. Não somente a cidade virou mercadoria, mas a qualidade da vida urbana, já que apesar de se ter uma aura de liberdade de escolha de serviços, lazer e cultura, é preciso ter dinheiro para pagar por isso. Nesse sentido, a criação de uma gestão democrática do espaço urbano pode ser entendida como direito à cidade. Segundo Harvey, essa tem que ser uma bandeira de luta global: adotar o direito à cidade como slogan e ideal político para unificação das lutas engendradas nos conflitos fundiários.

Ainda segundo Harvey, o direito à cidade é muito mais que a liberdade individual de acesso aos recursos urbanos, é o direito de mudar a nós mesmos ao mudar a cidade. Ideia embasada no pensamento do sociólogo e urbanista Robert Park quando diz que, ao fazer a cidade, o ser humano refaz a si mesmo. Portanto, o direito à cidade se constituiu como um direito coletivo, já que essa transformação depende da ação de um pode coletivo para remodelar os processos da produção do espaço urbano. Em suas palavras: "a liberdade de fazer e refazer as nossas cidades e a nós mesmos é, a meu ver, um dos nossos direitos humanos mais preciosos e ao mesmo tempo mais negligenciados" (HARVEY, 2013, s/p.). Nesse sentido, Viana (2O2O) afirma que as mulheres, suas interlocutoras de pesquisa e moradoras de ocupações urbanas paulistanas, produzem espaço, ao mesmo tempo que este espaço produz essas mulheres. Nas palavras da autora:

Com destino à cidade de São Paulo, esse deslocamento vai se constituir em espaço-tempo e luta cotidiana, num contexto em que essas mulheres se apropriam do espaço e da cidade a partir da luta diária que constroem e se inserem na produção do espaço urbano, produzindo e se apropriando do espaço - ao mesmo tempo que este espaço produz essas mulheres (VIANA, 2O2O, p. 44).

Os moradores das ocupações urbanas, entendidos aqui como sujeitos políticos, ao produzirem cidades, a partir da atuação política e coletiva na apropriação do espaço, estão reivindicando esse direito negligenciado e, assim, abrindo brechas para a tão sonhada revolução urbana. Portanto, brechas revolucionárias para o alcance do direito à cidade.

\subsection{AS REPRESENTAÇÕES SOCIAIS: CIDADE (IN)FORMAL?}

Os termos cidade e ocupação podem aparentar referir-se a conceitos polarizados, ou seja, à visão dicotomizada que sugere a existência de uma "cidade dividida" entre legal e ilegal, formal e informal, centro e periferia, ocupação e cidade. Porém, pelo contrário, a pesquisa busca superar essa visão dicotomizada, uma vez que considera que tais representações criam campos cegos sobre as formas reais da produção do espaço urbano, ou ainda, obscurecem o entendimento sobre a construção da cidade real. Para Maricato (2013a, p. 168, grifo meu), "é preciso, antes de mais nada, destruir essa representação ideológica sobre a cidade. É preciso construir a consciência da cidade real com as demandas populares". De modo geral, a representação ideológica da cidade é feita através de uma construção da ficção, que encobre a realidade científica (MARICATO, 2013a).

A chave de leitura dessa visão dualista, muitas vezes endossada nos debates públicos e acadêmicos, passa a ser da ausência, 
da negação, da carência. Construindo, assim, uma concepção homogeneizadora sobre tais territórios e seus moradores, repleto de estereótipos e estigmas sociais como violentos, desordenados, ilegais e perigosos. E também concepções socialmente construídas, ainda mais perversas, que vem ganhando força nas últimas décadas: territórios vistos a partir da criminalização ${ }^{36}$ e marginalização generalizada (ROSA, 2008). Visão apropriada em grande parte pela mídia, pela publicidade, pelos discursos políticos, por organizações não governamentais e, ainda, por agências internacionais de financiamento, que têm um papel especial na construção dessas representações.

Depois de décadas de pesquisas e estudos nos quais as ocupações urbanas foram lidas enquanto problema, ${ }^{37}$ diversos pesquisadores buscaram nesses territórios o entendimento sobre a construção da cidade real, ${ }^{38}$ voltando-se a essa realidade e ampliando o debate sobre a cidade oculta (MARICATO, 2013a). O acúmulo de reflexões a respeito desse outro olhar são base das reflexões propostas por esta pesquisa. São diversos os esforços de pesquisadores para a reinterpretação desses territórios, não mais a partir da visão dicotomizada da cidade. para citar alguns: Maricato (1999, 2011, 2013a), Pasternak-Tas-

36 A criminalização dos movimentos de luta por moradia e dos moradores de ocupaçōes tem ganhado força sobretudo após a tragédia do incêndio desmoronamento do Edificio Wilton Paes de Almeida, edificio ocupado no centro de São Paulo, em 2018. Uma onda de notícias estigmatizadas e preconceituosas têm figurado as ocupaçōes no debate público. O problema não e somente a construção das ideias, mas a ação do poder publico que passou a vistoriar as ocupações e gerar relatórios que apontavam inadequações. A questão e que a execução das "pendências" apontadas deveria ficar a cargo dos moradores e do movimento, tirando do horizonte o direito constituciona. Vale lembrar tambem que a critica a criminalização da pobreza sempre esteve no centro dos debates elaborados por Misse (2006).

37 Valladares (2005) analisa as diferentes construções sociais em torno das avelas cariocas ao longo das décadas, desde o início do século XX, em que a representaça opunha favela e cidade, que depois transforma "favela" como 1926) incla passando por sua insercão nas ciências sociais e mudanca de representacão que passa a considerar a complexidade e diversidade presentes nesses territórios, ainda que a ideia da da pobreza e da violência esteja em muitas visões associada às favelas. A autora faz ainda uma teitura da passagem da favela-problema à favela-solucão, discutindo a construcão dicotômica cidade/ favela que passa a ser questionada no finat do século XX, ainda que persista.

38 Trabalhos pioneiros como de Ferro (1969), Fischer (1977), Sampaio e Lemos (1978), Maricato (1976, 1982), Pasternak-Taschner (1978), Kowarick (1980), Valladares (1978, 1980), Mautner (1981), Bonduki e Rolnik (1982), Bolaffi (1982, [1975]. chner (2002), Kowarick (2002, 2009), Lago (2003), Valladares (2005), Telles et. al. (2006), Misse (2006), Almeida et. al. (2008), Rosa (2008, 2014), Cavalcanti (2009), Telles (2006, 2010), Feltran (2011, 2014, 2018), Marques (2014), Roy (2017).

Contrários a descrição do espaço dito periférico como uniformes, homogêneos e marcados pela ausência, esses pesquisadores apontam para a heterogeneidade social presente nesses territórios. Valladares (2005) traz um olhar que busca enfatizar a heterogeneidade das favelas e a negação da sua representação como espaço típico da pobreza. Seus estudos contribuem para construir o conhecimento sobre o "fenômeno favela", a partir de uma "sociologia da sociologia de favelas" cariocas. Rosa (2008) aponta que a diversificação de grupos sociais presentes nesses territórios, demonstra uma distribuição espacial muito mais complexa do que a divisão entre empobrecidos e ricos na cidade. Telles (2006) mostra que essa figuração homogeneizadora obscurece uma notável diversidade social e espacial, como também um dinamismo econômico que vem marcando essas realidades. A autora faz uma síntese dos principais apontamentos desses estudos:

Descobre-se que a cidade é muito mais heterogênea do que dife diferenciaçós internas, que pobreza e riqueza se distribuem de formas descontinuas, que os novos empreendimentos imobiliários e equipamentos de consumo alteram as escalas de proximidade e distância entre pobres e ricos, que os investimentos públicos realizados nos últimos anos desenham um espaço que já não corresponde ao continuum centro-periferia enfatizado pelos estudos urbanos dos anos 80 e que, enfim, somando tudo, se as desigualdades e diferenças existem e aumentaram nos últimos anos, elas se cristalizam em um espaço fragmentado que não cabe nas dualidades supostas nos estudos anteriores (TELIES, 2006, p. 60-61, grifo meu).

Rosa (2008) comenta que os conceitos favela e periferia trazem em sua origem uma abordagem dualista da cidade, figurados muitas vezes como territórios sem lei, sem Estado, sem urbanidade, ou seja, o oposto da ordem e da formalidade da dita cidade. Tais conceitos são perpassados com questões como da ilegalidade e da irregularidade, sendo estes os critérios diferenciadores dessa abordagem dualista. A questão é que as diversas formas de ilegalidade e da irregularidade urbanas não se restringem às 
ocupações, estão presentes na cidade como um todo, ${ }^{39}$ porém “a ilegalidade das camadas médias e altas não tem sido problematizada pelas forças progressistas que, desde a Constituinte, vêm atuando no campo das políticas urbanas" (LAGO, 2003, p. 2).

Nesse sentido, Roy (2017) afirma que a informalidade urbana deve ser entendida como uma lógica pela qual o valor espacia diferencial é produzido e gerenciado. E, portanto, não se restringe a uma porção da cidade, mas diz respeito a um modo de produção do espaço que conecta geografias aparentemente separadas pertencentes à mesma cidade. Só que a valorização da informalidade de uma parcela da sociedade e a criminalização de uma outra produz uma geografia urbana de valor espacial desigual. Segundo a autora:

A informalidade é tanto competência dos ricos e dos pobres [...] mas os ricos são expressões de poder de classe e, portanto, podem exigir infraestrutura, serviços e legitimidade. Mais importante, elas são designadas como 'formais' pelo Estado, nquanto outras criminalizadas (ROY, 2017, p. 16).

A partir disso, não se pretende conceituar ocupações no âmbito da informalidade, tampouco da ilegalidade, já que as distinções entre legal ou ilegal são temporárias e as relações entre elas instáveis. $\mathrm{Na}$ verdade, a legislação fundiária em muitos casos, sobretudo no que diz respeito às ocupações, não promove resoluções, mas sim conflitos, já que estabelece os termos pelos quais as transgressões serão seguramente legalizadas. A própria lei, em alguns casos, é uma forma de manipulação, complicação, artifício, violência e demonstração de clientelismo e privilégios, pela qual todas as partes, sejam públicas ou privadas, buscam seus interesses. Assim, a construção do que é legal ou ilegal é questionável, à medida que se baseia em uma régua móvel da regulação. E o que expressa Maricato (2013a, p. 123), quando diz que "a ilegalidade é funcional para as relações políticas arcaicas, para um mercado imobiliário restrito e especulativo, para a aplicação arbitrária da lei, de acordo com a relação de favor”. Não à toa muitas ocupações sofrem violentas reintegrações de posse a partir da aplicação da lei que protege a propriedade privada e não a função social, revelando que a relação entre terra e poder se mantém estreita (MARICATO, 2013a).

39 Como exemplo de que as diversas formas de ilegalidade e da irregularidade urbanas estão presentes na cidade como um todo, ver Lins (2008).
Como expressa Oliveira (2003, [1972]), a produção da cidade como um todo é repleta de ilegalismos resultantes da interação histórica entre o arcaico e o moderno. Convergentemente, Telles (2006) demonstra que os espaços urbanos são crescentemente atravessados por ilegalismos de todos os tipos, sendo os limiares entre o lícito e o ilícito, o legal e o ilgeal, entre o formal e informal cada vez mais tênues, ou ainda, indiscerníveis. Sendo assim, os territórios, feitos de práticas e conexões que articulam espaços diversos e dimensões variadas da cidade, não têm fronteiras fixas, mas situam-se em uma malha de ilegalidades que perpassam a cidade inteira. A autora afirma que essas supostas fronteiras, figuradas como fixas, criam um descompasso entre a dita cidade legal e a cidade real, afetando as formas de vida, que são constantemente atravessadas:

por uma crescente e ampliada zona de indiferenciação entre o lícito e $\circ$ ilícito, entre $\circ$ direito e $\circ$ não-direito, entre público e privado, entre a norma e a exceção, que passa por todo o entramado da vida social, pelas práticas e suas mediacões, pelos circuitos da vida urbana s conexões que se fazem nas pelos circulitos da vida urbana as conexoes que se fazem nas dobraduras da vida social, projetando una inquietante linha de sombra no conjunto da vida u (TELLES et al., 2006, p. 436).

Nesse sentido, Rosa (2008) argumenta que ao delimitar teoricamente fronteiras entre duas formas de produção da cidade, que chama de fronteiras em disputa, deixaria escapar às relações extremamente dinâmicas e móveis, ou ainda, a complexidade de relações, que caracterizam na prática tais fronteiras. Assim, a autora sugere a existência de permeabilidades e cruzamentos que muitas vezes são obscurecidos pelos pares conceituais de cidade-favela, centro-periferia, cidade formal-informal, legal-ilegal. Já Maricato (2013a), revela que o número de imóveis ilegais é tão significativo, que poderia dizer que cada vez mais "a regra se tornou exceção e a exceção, a regra". Segundo a autora, a cidade dita legal caminha para ser cada vez mais espaço da minoria.

O que se pretende enfatizar é que essa construção social não é somente problemática no campo das ideias, da criação ideológica em torno das ocupações e de seus moradores, mas também da ação, uma vez que essa dicotomização é funcional para endossar políticas de intervenção. Ao colocar um lado a cidade "legal", urbanizada, planejada, e de outro a cidade "sem 
urbanidade", uma "aversão à cidade" o que está comunicando é que essa "não cidade" é plausível de erradicação.

Dessa maneira, boa parte do século XX foi marcado pelas políticas remocionistas como rotina. Em meados do século, dado o número considerável de favelas (em especial no Rio de Janeiro) e bairros periféricos autoconstruídos (em especial em São Paulo), como também da intensa mobilização na luta pela permanência, começa-se construir o reconhecimento das ocupações como fenômeno social, fazendo com que as remoções passem a ser questionadas. Desde então, tais territórios passaram a se vistos como passíveis de "melhorias" e as políticas públicas de urbanização foram a ser disseminadas. ${ }^{40}$ Boa parte dessas intervenções realizadas de maneira "autoritária", com imposição de novas lógicas de organização que inserisse, a partir dessa visão, "formalidade" e "legalidade", desprezando significados e identidades construídas pelos moradores, suas lógicas de organização dos espaços, reapropriando o discurso de defesa da regularização fundiária ${ }^{41}$ e promovendo, em alguns casos, a chamada "remoção branca". 42

Portanto, apesar da "não remoção", essa visão homogeneizadora e dicotomizada da cidade passa a fazer parte das políticas, como se antes das possíveis intervenções públicas esses territórios estivessem em um estado de "vir a ser cidade", sem o reconhecimento que de fato já eram cidade.

O desconhecimento da cidade real facilita a implementação de politicas regressivas carregadas de simbologia O conhecimento um antídoto necessário para o desmonte da representação idoo-

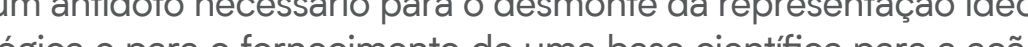
gica e para o fornecimento de uma base cientfica para a ação. Na sociedade brasileira, podemos dizer que a realidade é subversiva ao pensamento conservador. Dai o potencial de uma ação pedagógica sobre o reconhecimento da cidade real, em especial da "cidade oculta" (MARICATO, 2013a, p. 186, grifo meu).

40 Autores como Bueno (2000), Denaldi (2003) e Ferreira (2017) trazem o histórico das politicas de remoção à urbanização.

41 Lago (2003) explica que a regularização fundiária é uma bandeira de luta para alguns movimentos sociais de moradia porque garante, pelo menos a prin-

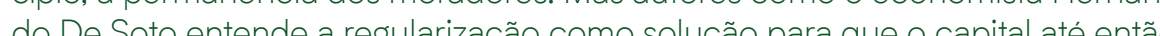
"morto" seja integrado a economia de mercado, ou seja integrar aquile que se considera "ilegal" na cidade "legal" e os "excluidos" na economia urbana.

42 Segundo Rosa (2008, p. 33): "A chamada remoção branca se caracteriza como uma expulsão indireta decorrente da valorização de parcelas do solo urbano e consequente aumento dos custos de vida da população residente".
Nesse sentido, esta pesquisa pretende contribuir para a desconstrução das representações dicotomizadas e para o conhecimento sobre a cidade real. A ampliação do debate sobre o direito à cidade tem a importante função de afastar a bruma que encobre a realidade ao desvendar a dimensão da exclusão (MARICATO, 2013a).

\subsection{AS NOCCÕES CONSTRUÍDAS EM TORNO DO TERMO PERIFERIAS}

As noções presentes no termo periferias são derivadas de construções sociais, a depender do contexto histórico, de sujeitos sociais (e suas lutas) e da produção de discursos. Não é tema desta pesquisa discutir as noções em torno do termo ${ }^{43}$ mas mediante o exposto até aqui, sobre a representação social e o quanto a escolha de determinados termos contribuem para a construção de significados, considerei importante explicitar a opção por seguir utilizando o termo periferias.

Parto do reconhecimento de que o termo periferias por vezes pode remeter à divisão entre centro e periferia, bem como a uma série de estigmas sociais construídos socialmente, inclusive as visões dicotomizadas que não dão conta de explicar a produção da cidade. No entanto, a preferência pelo uso do termo, e no plural, se deu por entender que é um termo consolidado, identitário e que carrega noções importantes para a argumentação desta pesquisa. ${ }^{44}$

A primeira noção que merece destaque é a construída a partir da insurgência dos movimentos sociais urbanos nas décadas de 1970 e 1980, período em que ocorreram significativas mudanças na sociedade brasileira, com a transição de um regime autoritário e repressivo para a redemocratização. Os moradores das periferias urbanas paulistanas passam a se constituir como sujeito social e histórico (SADER, 1988), ao engendrar lutas políticas a partir do chão de suas realidades periféricas. Assim,

43 Trabalham esse tema autores como Tanaka (2006) e D’Andrea (2013).

44 Não tratarei da noção centro-periferia, por exemplo, elaborada pela teoria da dependência, que explica as particularidades do desenvolvimento urbano de um pais industrial subdesenvolvido, a partir da correlação entre economias dos paises chamados "periféricos" com as economias dos paises chamados "centrais". 
"a periferia é conhecida e construída como noção explicativa da realidade urbana em um contexto histórico especifico, da ascensão das lutas sociais urbanas e das expectativas de transformação social a elas conferidas" (TANAKA, 2006, p. 18). Esse termo passa a ser utilizado e consolidado a partir desses novos atores sociais em interação aos acadêmicos que se dedicavam às questões urbanas (D’ANDREA, 2013), fazendo com que seja um termo consolidado na literatura desse período. Portanto, nesse contexto a utilização do termo é carregada de um sentido político e social transformador para esse contexto histórico, pois abriu "um campo de análise da cidade centrado nos conflitos e antagonismos sociais de caráter urbano" (TANAKA, 2006, p. 90). Ainda que a periferia tenha sido entendida como local de moradia da classe trabalhadora e de reprodução da força de trabalho em condições precárias, representada segundo Mautner (1999) pela tríade loteamento periférico-casa própria-autoconstrução, é entendida também como parte integrante da construção da cidade, já que o "significado preciso do conceito social periferia em São Paulo desvenda de fato um processo histórico de produção do espaço urbano, que se desenrolou concomitantemente à extensão interna do trabalho assalariado" (MAUTNER, 1999, p. 253).

Se enquanto nos anos 1970 e 1980 as periferias são lidas como espaços de onde emergia a inovação política, a partir dos anos 1990 passam a ser figuradas como sinônimo de pobreza e violência. No entanto, nessa mesma época o termo passa a ser apropriado pelos moradores periféricos, sobretudo pela juventude, a partir da produção artística decorrente da explosão de coletivos (D’ANDREA, 2013). Nesse sentido, passa a ser utilizado de maneira crítica e politizada, como forma de protesto para denunciar as condições a que os moradores de periferias estavam submetidos. D’Andrea (2013) coloca que a partir disso o sujeito periférico constrói uma nova subjetividade centrada no "orgulho" dessa condição, passando a agir politicamente a parti disso. Assim, o termo passa a ter um alargamento no seu significado, não mais construído em torno da noção de pobreza e violência, mas também cultura e potência, em dois sentidos: por- tador de possibilidades e de força/potência (D’ANDREA, 2013). ${ }^{45}$

A partir dessas noções decorre a escolha em utilizar o "mesmo termo" para designar um período tão extenso (1970-2020) e de tamanhas mudanças, ainda que sabidamente não se trata das "mesmas periferias". Concordo com Feltran (2011) quando, ao falar de periferias paulistanas, afirma que:

refiro-me a ambientes situados no tempo e no espaço, em que as pessoas se relacionam entre si e com outras esferas do mundo social, de modo plural e heterogêneo. Por outro lado, e simultaneamente, o termo periferias ajuda a reconhecer as regularidades, que se desenham nessas regiões da cidade e que demandam investimento analitico comparativo (FELTRAN 2011, p. 15).

Dito isto, é importante destacar que sua utilização não pressupõe uma conceituação homogênea desses territórios, como era feito muitas vezes anteriormente por significar locais distantes de comércios e negócios, desprovidos de equipamentos públicos e infraestrutura. Reconhece-se na atualidade a diversidade, o dinamismo, a heterogeneidade, a pluralidade, as diferenciações internas presentes nas periferias. Inclusive, por esse motivo, buscarei utilizar o termo sempre no plural. Precisamos, como fala Marques (2014, p. 30), "escapar cada vez mais de interpretações duais, abrindo espaço para diversos tipos de espaços (e grupos sociais) intermediários na metrópole". Sem que isso deixe de reconhecer o padrão de expansão periférica e as assimetrias socioeconômicas, já isso "não significa o completo desaparecimento de uma estrutura grosseiramente radial e concêntrica em suas dimensões mais gerais, e muito menos das desigualdades socioespaciais que caracterizam São Paulo tão fortemente". Por fim, vale ainda dizer que compartilho da visão de D’Andrea (2013, p. 179) quando diz que "no momento em que se aplacarem as diferenças sociais entre centro e periferia, esta dicotomia terá um sentido apenas geográfico, esvaziando, assim, a necessidade de uma afirmação subjetiva, social e política por meio do termo periferia. Enquanto isso não ocorrer, periferia e periférico seguem vigentes".

45 D’Andrea (2013) pontua a ambivalência presente nessa noção de potência, pois há o sentido emancipatório dessa condição de espoliação cotidiana do sujeito periférico, que parte do orgulho e não do estigmas, noção defendida ao longo da pesquisa, mas há também a potencialidade capturada pelo mercado, que vem constituindo nos últimos anos o consumo popular e construindo a chamada nova classe $\mathrm{C}$. 


\subsection{ALINHAVANDO ALGUNS PONTOS}

Alinhavar significa ajustar ou coser provisoriamente com pontos largos o que depois deverá ser cosido com ponto miúdo e definitivo (MICHAELIS, 2021). Assim, a partir do exposto ate aqui, buscarei nesta parte do texto alinhavar alguns pontos de maneira que sejam costurados no decorrer dos próximos capítulos, sem a pretensão de elaborar conclusões, mas sim possibilitar a formulação de novas questões e estimular reflexões a partir desta pesquisa.

A partir da perspectiva de que a ocupação não é um problema mas solução para aqueles que lutam pelo direito à cidade, uma questão de fundo que me acompanha, desde a graduação, é: o que apreendemos a partir dessas experiências vividas, que tem muito a ensinar sobre os diferentes modos de morar e de se relacionar? Experiências que se constituem a partir de outras lógicas possíveis de organização (das relações e do território), de urbanidade própria, uma cidade outra reconhecida e legitimada, e, portanto, ocupação entendida como uma forma própria de produção do espaço urbano. Cidades outras definidas a partir da concepção de Rosa (2014), como sendo:

cidades feitas de desenraizamentos, ajustes e ausências, mas também de relações, mediações, projetos e afetos, cuja multiplicidade de dimensões históricas, concepções em ato ou devires possiveis somente se dão a apreender a partir das práticas e narrativas dos sujeitos (ROSA, 2014, p. 34).

A tentativa do exposto até aqui foi demonstrar que não "falta cidade" nesses territórios, ao mesmo tempo que se tem o reconhecimento dos limites e contradições (inclusive, das condições difíceis enfrentadas no cotidiano), já que a forma ocupação é uma solução dentro de um sistema econômico que não permite outra alternativa a não ser ocupar, que por sua vez está inserido dentro das condições objetivas impostas. Portanto, não é escolha, mas resultado das necessidades cotidianas, da sobrevivência na adversidade (TELLES et al., 2006), da gestão diária do viver em risco (KOWARICK, 2009), atravessadas pelo tempo urgência. Noção muito aguçada a partir da Economia de Francisco e, nesse sentido, demonstra a necessidade de se pensar em uma nova economia.

A reflexão a respeito da visão dicotômica construída pelas representações em torno da cidade se dá pelo reconhecimento que essa polarização não tem dado conta das realidades urbanas em mutação (TELLES et al., 2006), bem como não tem dado conta da diversidade e dinamismo presentes nesses territórios, já que a produção do espaço passa por um intrincado jogo de atores sociais, a partir das suas práticas cotidianas, que são marcadas por conflitos, tensões, acertos, contradições e negociações.

$E$, por entender que as práticas cotidianas constituem os territórios, o cotidiano se mostrou como uma categoria analítica importante para pesquisa, pois sua leitura é imprescindivel para apreender quais elementos da prática corriqueira, enraizados no chão da realidade, comunicam a maneira como a vida é (re) produzida e contribuem para a construção de um projeto alternativo de sociedade. Como demonstra Sader (1988), a vida cotidiana é fundamental para não somente conhecer a realidade, mas sobretudo transformá-la. Portanto, as especulações teóricas presentes aqui decorrem das experiências vividas pelos moradores do Jardim da União.

O cotidiano é entendido aqui, segundo a visão de Chauí (1988), em sua contraditoriedade e ambiguidade como lugar de conformismo e resistência. Lugar de resistência por ser a base desde onde se gesta um projeto autônomo e de emancipação dos oprimidos. Visão que contrasta com os registros e análises que muitas vezes apresentam o cotidiano como vida repetida, manifestação do conformismo, da reiteração não crítica de uma opressão silenciada. Isso não quer dizer que se constitui como um lugar "mítico", em que os oprimidos se apresentam como são, libertos de qualquer ideologia opressora.

Assim sendo, o cotidiano reúne experiências díspares de atravessar e viver o território, com temporalidades e espacialidades próprias, ou seja, experiências urbanas multifacetadas e múltiplas, que muitas vezes ao serem definidas a partir da visão dicotomizada de cidade desconsideram a complexidade do mundo social. E, nesse sentido, a cidade aqui é entendida não apenas como cenário, mas como tema substancial de reflexão, cujas questões que nortearam a pesquisa partiram da cidade e não na cidade (FRUGGOLI, 2005). O fio condutor é a relação entre as práticas cotidianas de espaço e as representações associadas a elas, bem como os atores sociais envolvidos em ambos processos (das práticas e representações) e as disputas materiais (por exemplo, a terra) e simbólicas (por exemplo, ter ou não direito). 
A partir disso, esta pesquisa tem como argumento a dialética existente entre a ideia de que cidade produz ocupação contraposta à ideia de que a ocupação produz cidade. Dizer que cidade produz ocupação, significa reconhecer que ao estar inserida no modo de produção capitalista do espaço, a cidade deve ser entendida como mercadoria, organizada a partir de um mercado especulativo, elitista e excludente de grande parcela da população que não têm condições financeiras para acessar esse mercado, sendo a ocupação, portando, resultado precarizado desse processo. É a alternativa possível dentro de uma lógica mercantil de organização dos espaços urbanos, em que o valor de troca se sobrepõe ao de uso. Por isso, reconhece-se as condições difíceis, objetivas e precárias que os moradores de ocupações enfrentam no seu cotidiano.

Ao mesmo tempo, dizer que ocupação produz cidade é reconhecer a ocupação como parte integrante da produção da cidade. Nessa visão, elabora-se a concepção da forma ocupação não apenas como sobrevivência, mas também como forma de vida, de resistência a um sistema sociopolítico econômico que é por natureza excludente. Assim, com o "simples" ato da sua existência, insere-se no processo de resistência, num sentido de existir e resistir como duas coisas intrinsecamente relacionadas que culminam em um reexistir (FUKS, 2019). Assim, esse "reexistir" tem uma potência transformadora para alcançar o direito à apropriação, inerente ao direito à cidade.

O estudo de uma ocupação recente, bem como a recuperação da atuação das Comunidades Eclesiais de Base nas periferias paulistanas, tem como objetivo entender a forma de produção da cidade com a perspectiva de que outros mundos são possíveis, a partir de outras lógicas possíveis de organizar o território, baseadas na defesa da vida, do resistir e existir na cidade. Entendo as periferias como potência de confrontar o presente $e$ ampliar o horizonte dos possíveis (TELLES, 2006). 
A INCIDÊNCIA DAS CEBS

nas periferias paulistanas

No município de São Paulo, as décadas de 1970 e 1980 foram marcadas pela efervescência dos movimentos sociais que lutavam pelo direito à moradia digna e à cidade. Nesse contexto, a Igreja Católica teve um papel importante de apoio aos movimentos sociais através das Comunidades Eclesiais de Base (CEBs), em defesa da permanência dos moradores em seus territórios, da função social da cidade, da gestão democrática e participativa da cidade (SANCHES; STEVES; PIOTTO, 2O19). Portanto, parte da Igreja Católica contribuiu para organização coletiva e tentativa de conscientização política dos moradores das periferias paulistanas. ${ }^{46}$

As CEBs, em geral constituídas pela classe trabalhadora, estavam motivadas pela Teologia da Libertação e tinham como base a pedagogia do oprimido de Paulo Freire (2O19 [1968]). Podem ser entendidas como espaços de organização, mobilização e resistência popular, já que o contexto de seu surgimento remonta ao golpe militar de 1964 e a consolidação do regime, o que resultou na pulverização e no silêncio dos movimentos sociais. Para Camargo et. al. (1980), não é possível afirmar com exatidão o começo das CEBs, por se tratar de comunidades marcadas pela diversidade, por extrema fluidez e ausência de unidade e de organicidade.

Por se tratar de um contexto de regime ditatorial, com bloqueio dos canais institucionais de representação popular e de impotência da sociedade frente ao autoritarismo do Estado, nas pa- 
lavras de Weffort (1984, p. 93) "a única instituição que restava com força bastante para acolher os perseguidos era a lgreja Católica". Assim, as classes populares buscaram novos meios de organização e pressão social, encontrando na Igreja comprometida com o povo um espaço privilegiado de rearticulação de suas forças. ${ }^{47}$

Segundo Frei Betto (1985), as CEBs podem ser definidas como pequenos grupos organizados em torno da paróquia, no caso urbano, ou da capela, no contexto rural, por iniciativa de leigos, padres e/ou bispos. Possuem uma natureza religiosa de caráter pastoral e seu nome significa:

COMUNIDADES: por reunir pessoas que têm a mesma fé e moram na mesma região, compartilham da mesma "luta diária";

ECLESIAIS: pois são congregadas na Igreja, como núcleos básicos de comunidade de fé.

BASE: porque são integradas pelas classes populares, ou seja, por pessoas que trabalham com as próprias mãos. ${ }^{48}$

O teólogo Leonardo Boff (1986),49 caracterizando o processo de constituição das comunidades eclesiais de base, diz que:

47 Para além desse contexto do regime autoritário e mudanças no interior da lgreja Católica, como sera visto mais adiante, um fator que contribuiu para o surgimento e proliferação das CEBs, segundo Camargo et. al. (1980. p. 64-65), "foi a expansão de outros credos religiosos de larga aceitação popular: o espiritismo Kardecista, a Umbanda, mas principalmente os grupos pentecostais, estruturados em moldes mais comunitários e igualitários que o catolicismo. Neste sentido, um esboço das comunidades de base foram. reconhecidamente, as tentativas de descentralizar as paróquias e alargar as responsabilidades dos leigos

48 Boff (1986) explica os quatro sentidos de base, a saber: (1) base é sinônimo de fundamento, por isso a significação teológica da base é Jesus Cristo, (2) base e o que se encontra na posição oposta à cúpula da Igreja dos o povo: (3) base pode designar um processo pelasógico no sentido da dos, o povo, (3) base pode designar um processo pedagogico no sentido das todos sendo essa a significacão pedagógica da base: (4) base é sinônimo de pequeno grupo ou comunidade onde as pessoas partitham a fé e a vida e se judam mutuamente, sendo essa a significaç̃o antropológica da base.

49 No âmbito da Economia de Francisco, participei de dois encontros com Leonardo Boff que contribuiram para o desenvolvimento desta pesquisa, sendo eles: uma das 12 conferèncias do evento oficial, a unica brasileira, chamada "Responsabilidade Sócio-Ecológica: olhar global,ações territoriais", e evento organizado pela Articulação Brasileira pela Economia de Francisco Clara chamado "Terra, Teto e Trabalho: a Verdadeira Alegria e a Economia de Francisco e Clara.
[...] a massa, mediante as associações, se transforma num povo que comeca a recuperar a sua memória histórica perdida, elabora uma consciência de sua situação de marginalização, elabora ú a consciectia de sua situaçăo de marginalização, constroi um projeto de seu futuro e inaugura praticas de mobilização para mudar a realidade circundante [...] e constrói sob a participação de todos, com a presença forte do povo organizado, novo sujeito histórico emergente na sociedade e na Igreja (BOFF, 1986, p. 65-66, grifo do autor).

Para além do contexto de regime militar, dois outros importantes episódios se somam para que a lgreja se volte para aqueles que até então não tinham voz: o Concílio Vaticano II (1961) que foi levado para a América Latina com a reunião de Medellín (1968). Com esses dois eventos houve a "renovação" da lgreja, que passou a ter papel mais ativo na denúncia e na defesa dos direitos humanos. Esses encontros, contextualizados pela realidade socioeconômica e política da América Latina, são reconhecidos como raízes de uma abertura na Igreja Católica, com críticas à teologia tradicional e locais de formação da Teologia da Libertação. ${ }^{50} \mathrm{~A}$ Teologia da Libertação possibilitou uma outra interpretação da Bíblia Sagrada e do Cristianismo em comunhão com o sofrimento do povo. ${ }^{51} \mathrm{~A}$ partir disso, a lgreja esteve cada vez mais próxima do povo, enquanto o Estado se distanciava.

Para Sader (1988), as transformações ocorridas na Igreja Católica durante esse período não podem ser subestimadas. De um lado, a formação das comunidades de base não deve ser vista como simples sucessão de organização anteriores que incorporou leigos. A partir das comunidades e inspirados em Medellín, tais sujeitos passaram a participar ativamente, inclusive

50 A Teologia da Libertação nasce dentro da Igreja Católica, a partir de 960 na América Latina, depois do Concilio Vaticano II e da Conferência de Medellin. Ela e uma corrente tologica cristã que parte da interpretaçáo do condições de opressão impostas aos empobrecidos. Nesse sentido seja, das Micheel Löwy (2016) a ideia central da Teologia da Libertecão poderia ser resumida na frase "opcão preferencial pelos pobres". De acordo com Boff (1986, p. 114-116) a Teologia da libertacão "pretende ser a teoria adequada às práticas do povo oprimido o crente: ela quer ser o momento de esclarecimento e de animacão do caminho da libertacão popular sob a insiraç̃o evangélica. [.] A teologia da libertação quer ser verdadeira teologia isto é, um discurso que tenha Deus (encarnado) como centro, um Deus que está presente também nas inctâncias históricas, politicas, econômicas a sociais. Esta

51 Alterações significativas nesse sentido como a missa celebrada na língua local e não mais em latim como era de costume, como também o padre passa a celebrar voltado para os tieis. 
interferindo na própria organização interna da lgreja, alterando o funcionamento das paróquias e o papel dos vigários. De outro lado, as críticas feitas à organização social não se limitavam a questões secundárias, mas denunciavam os próprios fundamentos do sistema. Boff (1986) mostra esses dois pontos a partir do relato no âmbito do importante Encontro Intereclesial, realizado em 1978 em João Pessoa:

Vivia-se um fato inaudito: depois de quatrocentos e oitenta anos de silêncio o povo religioso e oprimido tomou a palavra e rompia o monopólio da fala do corpo de peritos da lgreja: catequista, o padre e o bispo. Os assessores, agentes de pas foral e os bispos, puderam ouvir da boca do próprio povo a espoliação econômica, política e cultural a que estão submetidos, seus gritos por justiça e participação. Dois dados criaram consensos: a raiz principal da opressão que sofrem provém do sistema capitalista elitista e excludente; o povo resiste e se

tos populares (BOFF, 1986, p. 78-79).

A declaração de Medellín é dominada por um chamamento à "presença mais intensa e renovada da lgreja na atual transformação da América Latina" (SADER, 1988, p. 152). O que ganha ênfase a partir desses dois eventos é a denúncia das estruturas sociais, que geram profundas desigualdades, exploração miséria. Assim, a partir desse contexto, Frei Betto (1985) aponta que o desafio posto à Igreja Católica era romper com os interesses e privilégios da classe dominante, uma vez que ha o reconhecimento de que, no regime capitalista, a lgreja esta atrelada aos interesses da burguesia. Portanto, para que ela participe efetivamente do processo de libertação do povo preciso que esteja comprometida com as classes populares. Este foi o desafio lançado pela esperança de libertação dos povos latino-americanos à lgreja, ou seja, através de suas comunidades de base, descobrir como tornar essa esperança práxis de transformação (BETTO, 1985).

Para o cumprimento desse desafio, os agentes pastorais - padres, religiosos, leigos - apenas assessoravam, com a atenção para que seus membros fossem sujeitos de sua própria história. Para isso, era necessário: "viver vinculado ao povo, comungando sua vida (...) para entender sua palavra" (BETTO, 1985, p. 18). Do contrário, havia o perigo de uma atitude colonialista, ao introjetar na mentalidade popular valores, por exemplo, elitistas e academicistas.
Em 1976, na assembleia do Movimento do Custo de Vida, o bispo dom Mauro Morelli proclamou que "nós devemos ser sujeitos da nossa própria história”, que tem intrínseca relação com a metodologia freireana. Sader (1988) acredita que foi a partir dessa fala que emergiu essa expressão, amplamente adotada por movimentos sociais e autores.

É a partir desse período que o povo passa a ter a consciência que têm direito a ter direitos. Os moradores ao interpretar suas condições de vida passam a reivindicar serviços básicos, como água, esgoto, luz, redes viárias, educação, saúde etc. Todas essas ações começaram a construir novos valores vinculados às reivindicações feitas, pois no lugar do pedido de um favor apareceram as reivindicações de direitos:

Os problemas mais agudos da periferia metropolitana, ou seja, os de saneamento, iluminação, segurança, calçamento etc. São percebidos como privações que afetam a todos da Comunidade, flagrantes injustiças inscritas no espaço urbano. Concretizam-se nestas circunstâncias os temas de reflexão sobre ascrituras, condenco bre as Escrituras, condenando-se a desigual repartição dos recursos da cidade e suas consequencias sobre a qualidade de vida dos habitantes desprivilegiados. "A CEB é um lugar onde se cria consciência de por que o ônibus é assim, por que não tem esgoto, por que o salário é assim.” E essa reflexão é sistemática. As fundamentais exigências cristãs de igualdade são colocadas como critério para condenar a espoliação refletida em toda a tecitura da organização do espaço metropolitano. Surgem, nesse contexto, dos grupos organizados nas CEBs, reivindicações dirigidas às autoridades. Sua natureza política é marcada por traço característico: trata-se de uma exigência de justça de justiça e não de um pedido de favor (CAMARGO; SOUZA;
PIERUCCI, 1980, p. 75, grifo meu).

A construção desses novos valores foram produto da própria vida dessas comunidades, já que, em um contexto de regime autoritário, houve o reforço das relações interpessoais, fortalecimento dos laços primários de solidariedade e das redes informais para a solução dos problemas cotidianos, ou seja, para sobrevivência diária de grande parte da população.

As relações primárias de solidariedade e as referências cristãs induziram à reelaboração idealizada de uma vida comunitária do passado rural. Nesse quadro se produz uma forte coesão interna e um reconhecimento pessoal construído à base da confianca entre seus membros. É a partir dessa sociabilidade primária que seus seus menos. É membros efetuam uma reelaboração das experiências cotidianas ações coletivas visando transformá-las (SADER, 1988, p. 162). 
A partir desse período passaram a atuar de maneira mais coletiva, como por exemplo, mutirões organizados para levantar um salão paroquial, mobilização para reclamar da falta de ônibus, organização de uma creche comunitária, circulação de um abaixo-assinado para reivindicar a coleta do lixo, organização de um movimento para a defesa dos direitos dos moradores em ocupações de terra, ou dos direitos à educação e uma grande diversidade de organizações e movimentos populares (SADER, 1988).

De acordo com Camargo et. al. (1980), o papel da lgreja nesse contexto foi fundamental no plano das organizações por local de moradia. Segundo os autores, as CEBs podem ser consideradas como sendo uma das mais importantes matrizes de organização popular, possibilitando que os participantes utilizassem a estrutura da Igreja, tanto em aspectos organizativos, quanto materiais.

Assim, é possível afirmar que, de acordo com Frei Betto (1985), na origem são dois os motivos que unem os membros das CEBs, seja no contexto rural ou urbano: a expropriação da terra e a exploração do trabalho. Esse empenho de luta não resultou de forma espontânea, mas, como exposto, foi uma resposta à conjuntura nacional da época, pois o regime militar, ao suprimir os canais de participação popular, fez com que a população procurasse outros espaços de mobilização. Assim, se antes buscavam na religião um "sedativo" para os problemas cotidianos, a partir desse momento encontraram um espaço de discernimento crítico, pois as CEBs participaram ativamente da oposição popular. Uma vez que, "o povo redescobriu a Igreja, não apenas como espaço de expressão e nutrição da fé, mas também como espaço de organização e mobilização" (BETTO, 1985, p. 22). De acordo com Frei Betto, as CEBs percorreram três etapas interligadas:

1) COMUNIDADE EM SI: centrada na motivação religiosa, baseando-se no Evangelho para encontrar possíveis caminhos para a atividade social.

2) MOVIMENTOS POPULARES: participação dos membros independente da religião ou crença, o que os une é estar ao lado dos oprimidos. Esse processo foi importante porque ajudou a (re) criar movimentos populares autônomos.

3) FORTALECIMENTO DO MOVIMENTO OPERÁRIO: muitos dos membros participavam dos Sindicatos, procurando valorizá-los como verdadeiro órgão de classe.
Dessas três etapas surgiu uma quarta que objetivava buscar novos canais de expressão política para a sociedade civil brasileira, ou seja, uma reformulação partidária. ${ }^{52}$ Portanto, é possível perceber que as CEBs não se fecharam em si mesmas, mas apoiaram os movimentos populares, pois ajudaram a criar ou fortalecer formas de organização e mobilização popular autônomas, desvinculadas do Estado e da Igreja.

\subsection{A BUSCA PELA LIBERTAÇÃO}

Dietrich Bonhoeffer, teólogo protestante, condenado à morte por haver participado de um complô contra Hitler, escreveu da prisão em 1944 as seguintes palavras proféticas: “Um dia há de chegar em que os homens novamente serão chamados a profeir a Palavra de Deus, de tal maneira, que uma linguagem nova, talvez completamente a-religiosa, mas será uma linguagem libertadora e redentora como a fala de Jesus. Então os homens hão de se espantar com ela, mas mesmo assim serão dominados por seu poder. Será a linguagem de uma nova justiça e verdade, a linguagem que anuncia a paz de Deus com os homens e a proximidade do seu Reino. 'Espantar-se-ão e tremerão por causa de todo o bem e por causa de toda a paz que lhes dou' (Jr $33,9)$ ". Estas palavras parecem cumprir-se perfeitamente com a forma de cristianismo vivido nas milhares de comunidades eclesiais de base espalhadas por todas as periferias de nosso país, nas quais a Palavra de Deus se revela como fator de transformação e de libertação dos oprimidos, causando espanto e tremor no sistema imperante e em seus ideólogos (BOFF, 1986, p. 77).

O fio condutor de todas as CEBs é a busca pela libertação. A palavra libertação sobressai no vocabulário dos seus membros, pois além de estar presente nos ritos religiosos, procurava fazer com que seus membros passassem de uma consciência social reformista para uma consciência de transformação 
social. ${ }^{53}$ Almejava a modificação do modo de produção capitalista, chegar à raiz dos males sociais: a contradição entre capital e trabalho. Esse foi um processo que se deu aos poucos, pois não se percebia uma noção de consciência de classe, mas, com o apoio dos movimentos populares, cada vez mais se tornava explícito um forte sentimento de justiça e a consciência dos direitos do povo.

Sader (1988) traz um folheto produzido na época, com um texto que serviu de roteiro para a cerimônia que costumavam celebrar nos encontros das CEBs. Com ele é possível perceber a emergência de temas e estilos da Teologia da Libertação e do método ver-julgar-agir em grupos de jovens católicos que atuavam nos bairros da periferia:

Certamente não basła refletir, ver mais claro ou mesmo falar. É necessário agir. Esta é a hora de ação. De ação inteligente firme. Por isso, assumimos contigo, Cristo, o compromisso de seguir o exemplo de quem, com coragem, comecou o caminho da libertação. Não vai ser ter uma hora nem de um dia (1) mas vamos ter paciencia a firmeza dequem tem ac da vitória (SADER, 1988, p. 146, grifo meu).
O roteiro indicava ainda que os presentes cantariam o "Caminhando" 54 , de Geraldo Vandré, canção que foi incorporada nos ritos como peça quase obrigatória dos tempos de resistência. Depois, alguém proferiria as palavras finais de um texto previamente preparado, que se iniciava com uma interpelação "E agora?":

Esse Natal dos grupos de jovens pode dar nascimento a muitas coisas boas para todos nós: maior entrosamento entre nossos grupos, trabalho em conjunto, troca de experiências, pistas para levarmos à frente nossos trabalhos para que brotem em nossas bases comunidades vivas de jovens que despertem do sono e possam acordar os que continuam mortos no comodismo e no egoísmo. Tudo isso depende de você, de mim, de is. Caminhemos de mãos d nós. Caminhemos de mãos dadas. Um dia virá, você vai ver
(SADER, 1988, p. 146).

Esses trechos demonstram a contraposição entre morte referida ao egoísmo e ao comodismo e vida da ação comunitária, visando uma libertação. No lugar de um catolicismo centrado na salvação individual e no conformismo político, há a busca por outro tipo de engajamento coletivo e político. Sader (1988) expõe que esse foi apenas um exemplo de cerimônia, entre inúmeras que ocorreram, que trazia a "marca de Medellín", onde a Conferência dos Bispos da América Latina comprometeu a Igreja na luta contra as causas sociais da miséria.

54 Essa canção tinha por titulo "Pra não dizer que não falei de flores", mas ficou conhecida como "Caminhando". De autoria de Geraldo Vandré, foi por ele apresentada no Festival da Canção do Rio de Janeiro em 1967 e imediatamente tornou-se um dos hinos da contestação daqueles anos. Seu refrão diz: Vem vamos embora que esperar não é saber / Quem sabe faz a hora não espera acontecer / Pelos campos há fome em grandes plantações / Pelas ruas marchando indecisos cordões / Ainda fazem da flor seu mais forte refrão / E acreditam nas flores vencendo o canhão / Há soldados armados amados ou não, / Quase todos perdidos de armas na mão, / Nos quartéis Ihes ensinam uma antiga lição / De morrer pela pátria e viver sem razão. / Nas escolas, nas ruas, campos, construções, / Somos todos soldados, armados ou não, / Caminhando e cantando e seguindo a canção, / Somos todos iguais, braços dados ou não. / Os amores na mente, as flores no chão, / A certeza na frente, a história na mão, / Caminhando e cantando e seguindo a canção, / Aprendendo e ensinando uma nova lição. A música foi proibida pelo regime militar e, desde o começo dos anos 70, adotada pelos grupos comunitários como expressão de resistência. 


\subsection{E A IGREJA SE FEZ POVO 55}

A Comissão de Justiça e Paz, a partir da qual a arquidiocese de São Paulo passou a atuar de maneira mais direta, teve um importante papel nesse período na defesa de direitos humanos. ${ }^{56}$ Para Camargo et. al. (1980, p. 61): "a intransigente luta contra a tortura praticada por aparatos militares e policiais, a defesa de presos políticos e de presos comuns, a ação junto aos menores careniciados constituem exemplos de ação eclesial, enquanto formulação positiva de uma ética social". A Igreja passa a ser abrigo e espaço para os diversos movimentos de resistência ao regime autoritário e opressor, inclusive os desvinculados de filiação religiosa.

Em 1973, Dom Paulo Evaristo Arns iniciou a Operação Periferia, ${ }^{57}$ com o objetivo de criar centros comunitários nos bairros periféricos, lugares:

[...] do povo, onde o povo pode ir, ter uma semiprofissionalização, regularizar documentos, onde as crianças podem receber as primeiras instruções religiosas e, onde, aos sábados e domingos, as pesso s podem se encontrar e organizar o seu lazer (BITTENCOURT: MARKUN, 1979, p. 59).

55 "E a lgreja se fez povo" é um livro de autoria Leonardo Boff (1986) que retrata a inserção de amplos setores da lgreja Catolica nos meios populares. que segundo o autor permiliu "que dai emerja realmente a lgreja como Povo de Deus com características populares", uma igreja com "compromissos de transformação, a partir da fé, das condições de opressão e empobrecimento" (BOFF, 1986, p. 15).

56 Em 1975, a Comissão de Justiça e Paz da Arquidiocese de São Paulo pediu aos pesquisadores do CEBRAP um estudo sobre as condições de vida dos trabahadores paulistanos que resultou no importante livro "São Paulo 1975: foi a definição des prioridades por parte de Arquiliocese de São Paulo paça fora de rados essenciais sendo eles: a Pastoral do Mundo do Trabalho, a Pastoral dos Direitos Humanos e Marginalizados, a Pastoral Pastoral da Periferia e a Pastora das Comunidades Eclesiais de Base (CAMARGO: SOUZA. PIERUCCI. 1980). Escas aç̃os demonstram a atenç̃o dada às condicões árduas e dificeis da

57 Não seriam apenas igrejas, destinadas a celebrar missas, ou seja as tradicionais celebrações dominicais. Seriam centros com salas e salões destinados a atividades como reuniões dos clubes de mães, dos grupos de catequese. dos núcleos da pastoral operária, creches, cursos, grupos de jovens para fazer música ou teatro.

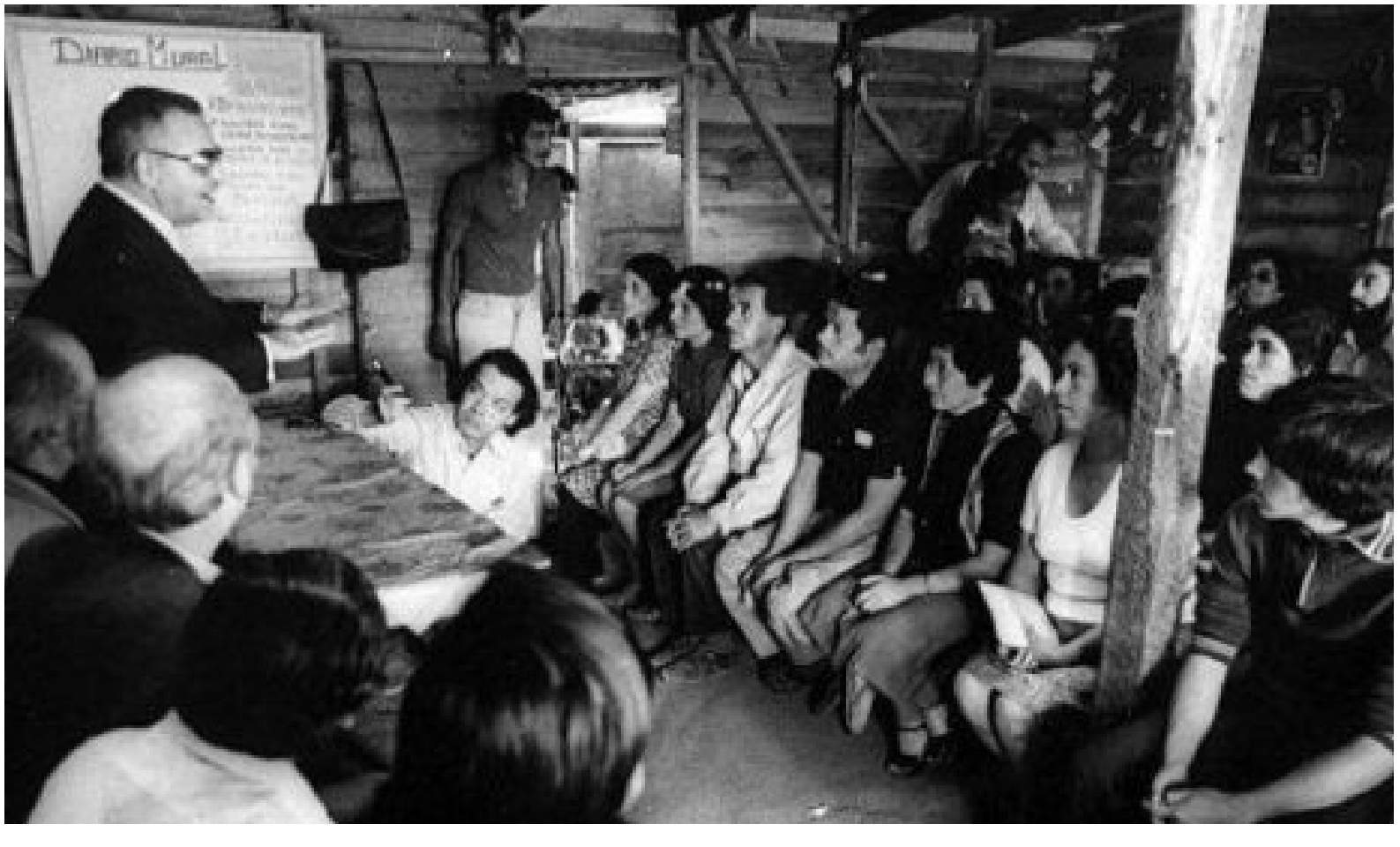

FIGURA 2.1 - Dom Paulo Evaristo Arns participando de uma reunião no âmbito da Operação Periferia.

Buscavam, com isso, despertar o espírito e a atuação missionária da Igreja Católica em São Paulo, que se lançava com empenho na formação das comunidades de base, que a partir de então iriam proliferar na metrópole. A Figura 2.1 mostra o cardeal Dom Paulo Evaristo Arns participando de uma reunião num dos cem centros comunitários construídos pela Igreja, com dinheiro obtido com venda de palácio luxuoso que pertencia à Arquidiocese. Em um dos encontros, ele disse: "O cardeal admira e apoia vocês e quer aprender de vocês” (BOFF, 1986, p. 80).

A comunidade de Santa Margarida, localizada na Vila Remo, Zona Sul de São Paulo, é um exemplo que demonstra a incidência das CEBs na construção das periferias paulistanas, já que a atuação da CEB foi importante para a consolidação desse território. Essa CEB surgiu depois que o padre local promoveu um encontro para reflexão sobre as mudanças na Igreja com o Concílio Vaticano II e Medellín:

Começamos a ver, então, como era a nova Igreja: uma lgreja preocupada com a vida, as necessidades e as labutas do povo. Olhamos o nosso bairro e a nossa vida, e vimos que havia muita coisa errada e ruim. Se essa era a Igreja daqui a gente tinha que fazer alguma coisa para melhorar (SADER, 1988, p. 158). 
Logo depois formou-se um clube de mães, como um espaço para dialogarem sobre os seus problemas e procurar soluções em comum. Em geral, os temas partiam da leitura da bíblia, de folhetos litúrgicos, de problemas vividos no cotidiano de seus membros ou mesmo os aspectos práticos de alguma iniciativa decidida pela comunidade. A prática nas comunidades visava mudar a realidade vivida e produzir nos participantes uma dimensão crítica e uma capacitação transformadora.

A importância da lgreja para as CEBs decorre ainda do fato de ela oferecer uma legitimação teológica para as aspirações terrenas de seus membros. Na medida em que a lgreja e reconhecida como instituição de Deus na terra e na medida em que assumia os reclamos populares enquanto exigência evangéli$\mathrm{ca}$, ela abriu um espaço de legitimidade por onde os protestos sufocados vieram à tona. Nas ambiguidades da cultura popular, entre o conformismo e o protesto, o conformismo costuma ser resultado de uma experiência que diz que "as coisas são assim porque sempre foram, e as tentativas de mudar só trazem mais malefícios". Quando uma instituição como a Igreja sacramentou os sentimentos populares, a vontade de mudança encontrou um lugar e um modo de ser proclamada. Daí a importância que os próprios membros das CEBs atribuíram à presença dos agentes da lgreja (SADER, 1988, p. 161).

O depoimento da irmã Cecília Hansen, que atuou na CEB da Vila Remo por 17 anos tendo iniciado em 1972, demonstra como foi esse período de luta por direitos. Segundo ela, na década de 1970, após o Concílio Vaticano II, D. Evaristo Arns fez um apelo às Congregações para que as irmãs fossem atuar nas periferias paulistanas. ${ }^{58}$ Para a irmã Cecilia: "Esse chamado veio ao encontro do meu desejo de trabalhar com os (as) empobrecidos (as)". Ela lembra das condições de precariedade e de ausência: "Tudo faltava. Não tinha água encanada, coleta de lixo, faltavam escolas, creches, transporte, etc." E menciona o contexto de migração: "A maioria do povo vinha do Nordeste e do Interior de Minas, desenraizada de sua família, cultura e ambiente em busca de melhores condições de vida" (HANSEN, 2018, s/p.).

58 "O Concilio Vaticano Il encerrou-se em 1965. No seu final, os bispos brasileiros reunidos em Roma aprovariam o Plano de Pastoral de Conjunto para o quinquênio 1966-1970, o qual expressava o voto, a vontade e a esperança da CNBB de que uma nova lgreja viesse a surgir das comunidades de base" (CAMARGO; SOUZA; PIERUCCI, 1980, p. 65).
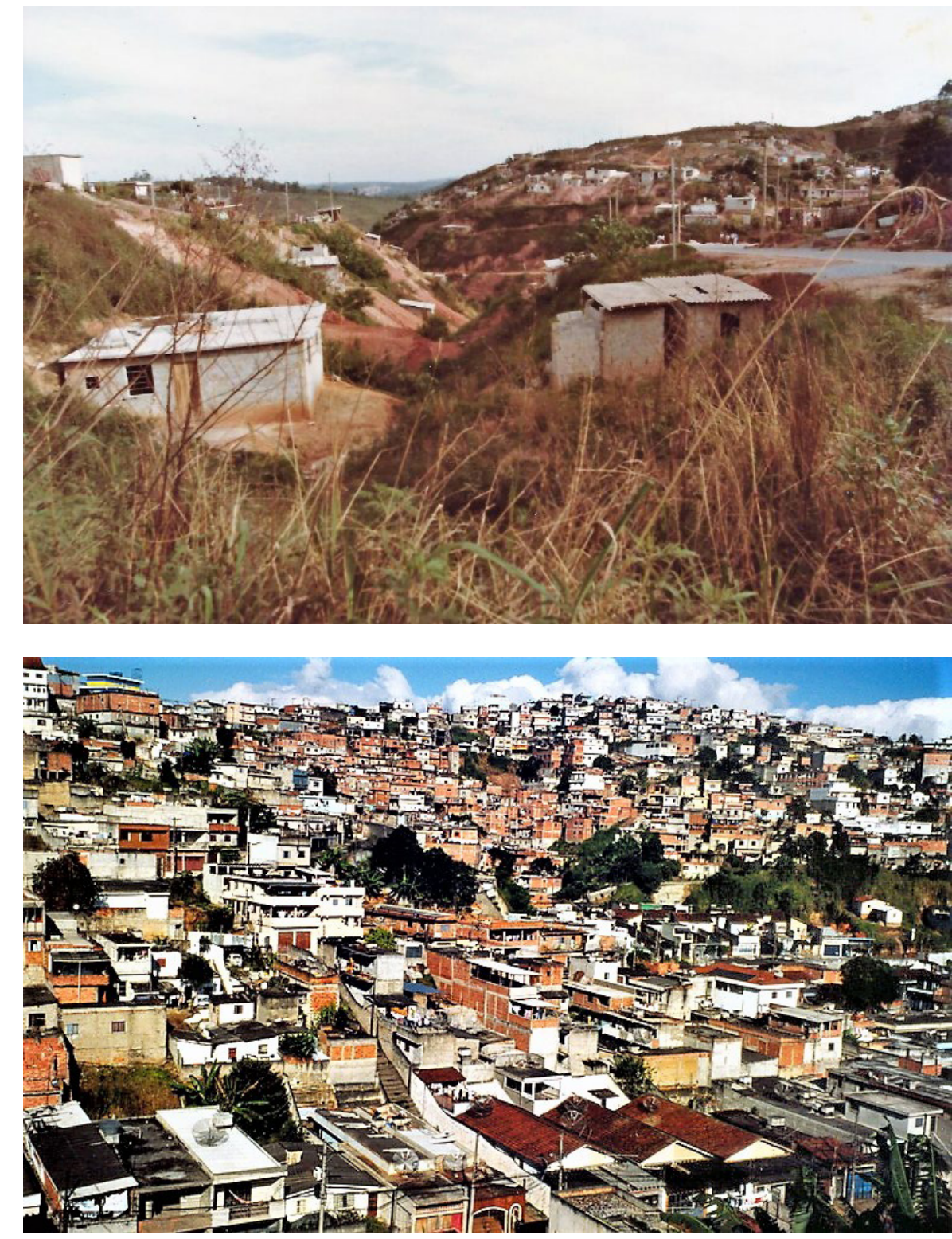

Para Irmã Cecília, que iniciou seu trabalho com a formação da CEB, essa era uma nova forma de viver a Igreja, pois todos "tinham voz e vez", dos religiosos aos leigos. Na CEB faziam a leitura da Bíblia a partir do oprimido, sustentando assim uma espiritualidade encarnada não somente na Palavra de Deus mas também na vida do povo. Foi a partir disso que, por exemplo, formaram o Clube de Mães (Figura 2.4):

Sendo uma Igreja onde todos (as) tinham voz e vez, o povo trazia para as nossas celebrações e encontros seus problemas, suas dificuldades, suas necessidades, suas angústias, suas esperanças. Formaram-se vários grupos conforme as suas necessidades. Assim, também as mulheres se organizaram em cessid. Todas as comunidades nos bairros tinham um em grupos. Todas as comunidades nos bairos tinham um grupo, (HANSEN, 2018, s/p.) 


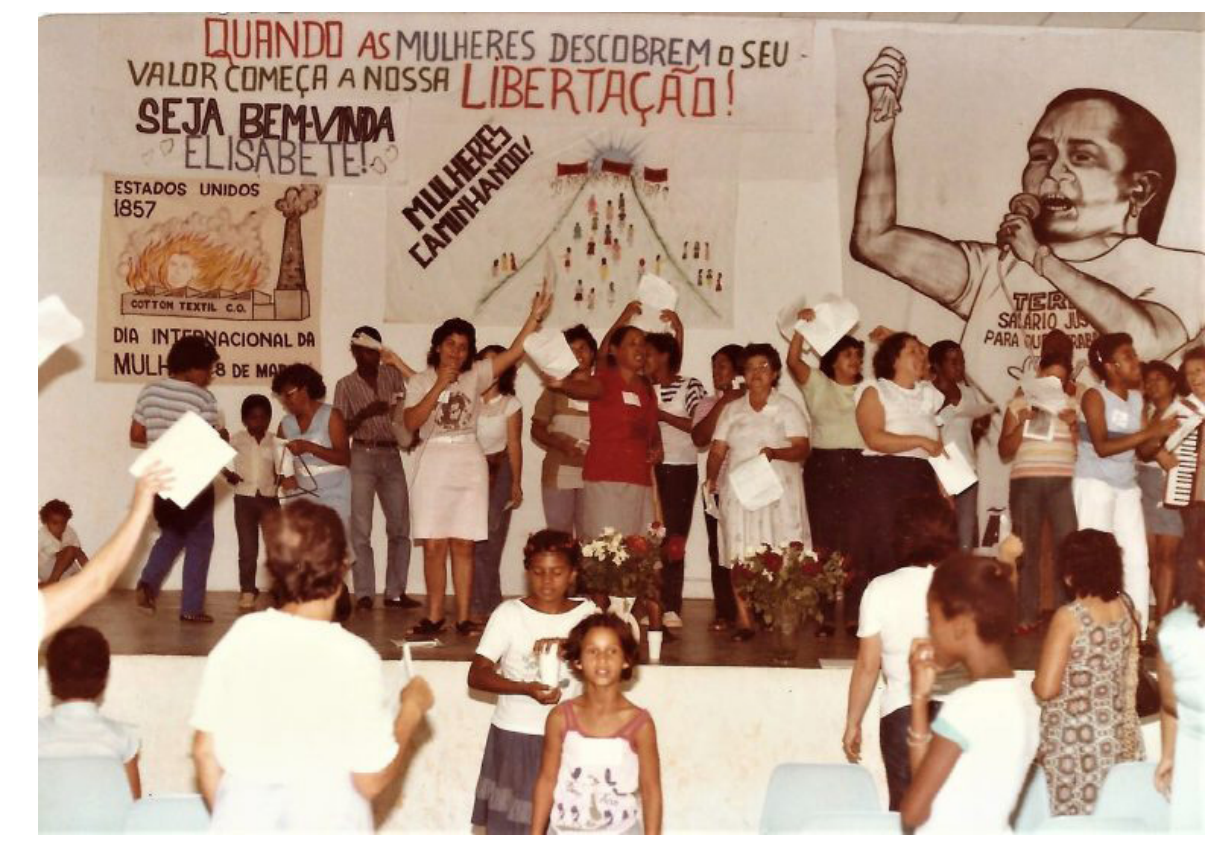

FIGURA 2.4 - Celelebração do Dia Internacional da Mulher de 1980 em Vila Remo.
FONTE: Blog Mission

\subsection{UMA IGREJA EM SAÍDA:59 O CLUBE DE MÃES}

O Clube de Mães é considerado o maior movimento feminino contra a ditadura. A partir desses grupos, as mulheres reivindicaram diversos direitos como creches, escolas, água, transporte etc. Se nem todas as reivindicações eram atendidas, para a irmã Cecília o importante foi o salto na consciência das mulheres, pois saíram das suas casas e passaram a enxergar outras possibilidades na vida, assumindo assim seu papel na Igreja e na sociedade.

O Clube de Mães contribuiu para a organização do Movimento do Custo de Vida (MCV), também conhecido como Movimento

59 O Papa Francisco reforça esse conceito de "Igreja em saida" logo no primeiro ano do seu Pontificado quando escreve na Evangelii Gaudium: "A Igreja em saída é uma igreja com as portas abertas. Sair em direção dos outros para chegar às periferias humanas não significa correr pelo mundo sem direção nem sentido. Muitas vezes é melhor diminuir o ritmo, pôr à parte a ansiedade para olhar nos olhos e escutar, ou renunciar às urgências para acompanhar quem ficou caido à beira do caminho. [...] Prefiro uma igreja acidentada, ferida e enlameada por ter saído pelas estradas, a uma Igreja enferma pelo fechamento e a comodidade de se agarrar às próprias seguranças" (FRANCISCO. 2013, p. 40-43).
Contra a Carestia (MCC). ${ }^{60}$ A figura 2.5, de 1978, mostra algumas membras do Clube das Mães encarregadas de entregar um abaixo-assinado em Brasília.

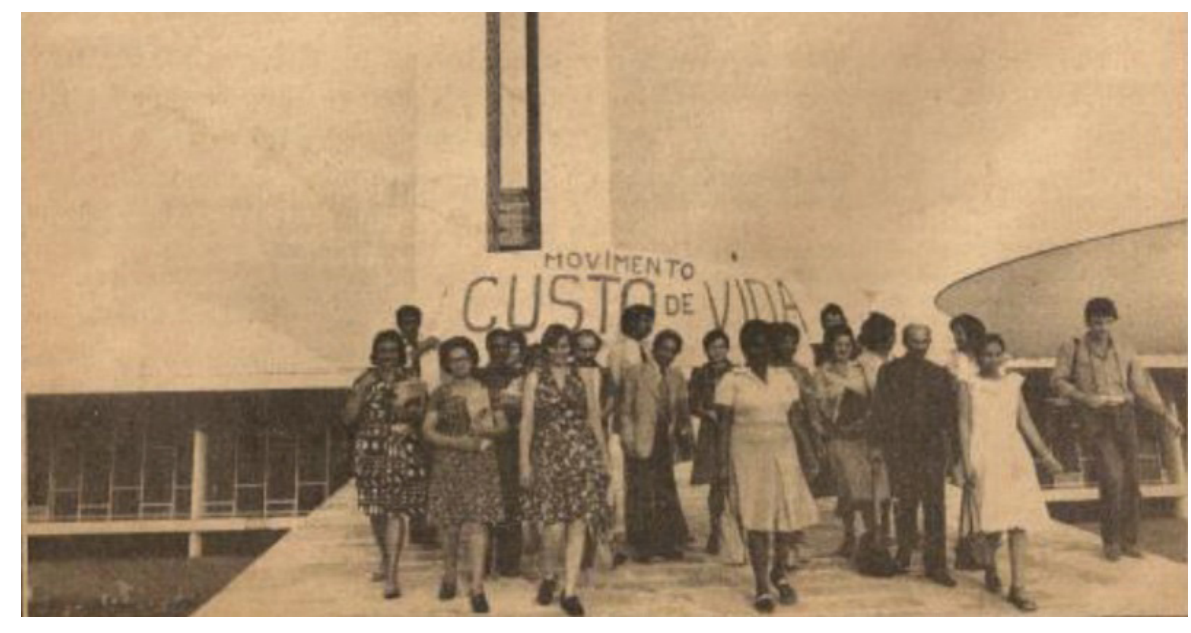

FIGURA 2.5 - Comissão do MCV encarregada da entrega de abaixo-assinado em Brasilia em 1978.

Nesse mesmo ano, em 1978, as "mães da periferia" levaram mais de 20 mil pessoas à Praça da Sé num ato público para protestar contra a política econômica do governo militar. ${ }^{61}$ Muitas pessoas foram impedidas de chegar até a praça com controles, inclusive nas rodovias, que ficaram interditadas para impedir a chegada na manifestação dos ônibus vindos de diferentes cidades (Figuras 2.6 - 2.9).

60 Para Brant (1980), o Movimento do Custo de Vida foi uma tentativa prática de executar um modelo de movimento mais amplo que reunia um grande número de pequenos grupos estruturados e conscientes, pois "uma coordenação de dezenas de membros reuniu-se periodicamente, meses a ho, para permifir que cada proposta ali apresentada fosse levada as bases...... mento é consula die a e permanente refoça a convicçáo de que o movide manobra de uma direção externa” (BRANT, 1980, p. 19).

61 "Milhares de pessoas participaram de ato público em São Paulo organizado pelo Movimento Contra o Custo de Vida. A Polícia Militar lançou bombas e cães contra a multidão, que se refugiou na Catedral da Sé. Entre as vitimas, havia donas de casa e crianças da periferia. No ato público, o movimento divulgou um documento com 1,3 milhão de assinaturas contra o aumento do custo de vida. A inflação oficial no pais vinha crescendo nos últimos anos e chegaria a $40 \%$ em 1978. Números haviam sido manipulados em 1973, quando o governo divulgou o índice de $15,5 \%$, mas a inflação real fora de 22,5\%, de acordo com estudo do Banco Mundial. O governo ignorou o manifesto do movimento" (ALONSO JR. et al., 1978, s/p). 


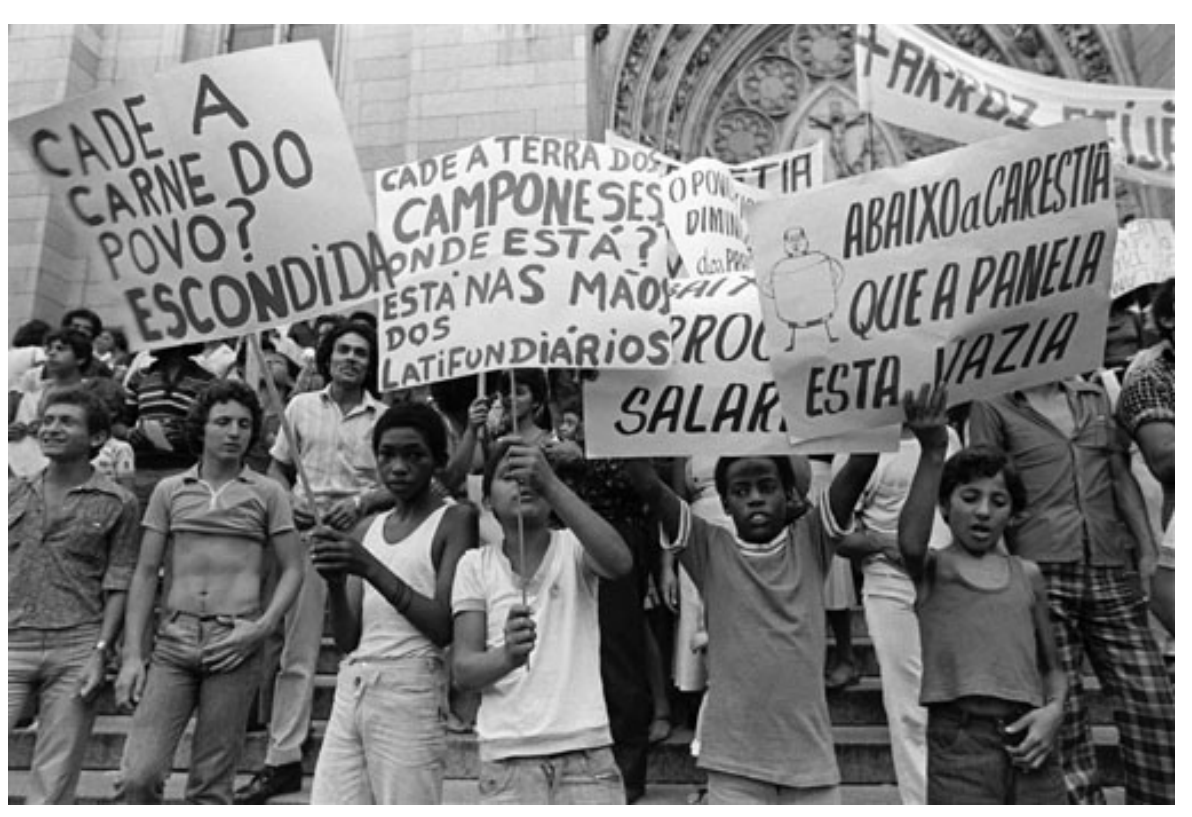

FIGURA 2.6 - Manifestação do Movimento Custo de Vida na Praça da Sé, em São Paulo.
FONTE: Blog Missionárias Servas do Espirito Santo.

FIGURA 2.7 - Manifestação do Movimento Custo de Vida na Praça da Sé,

em São Paulo.

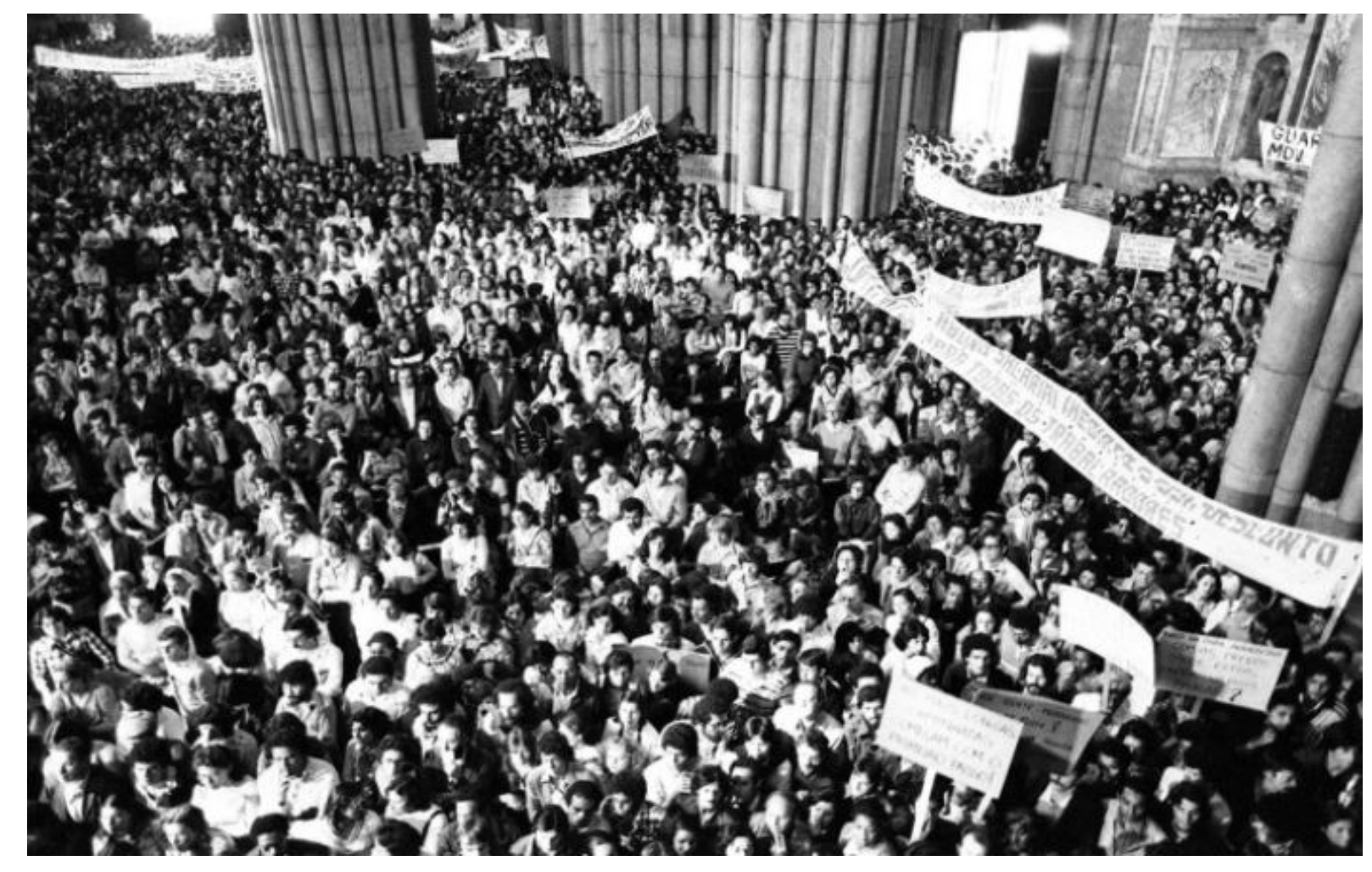

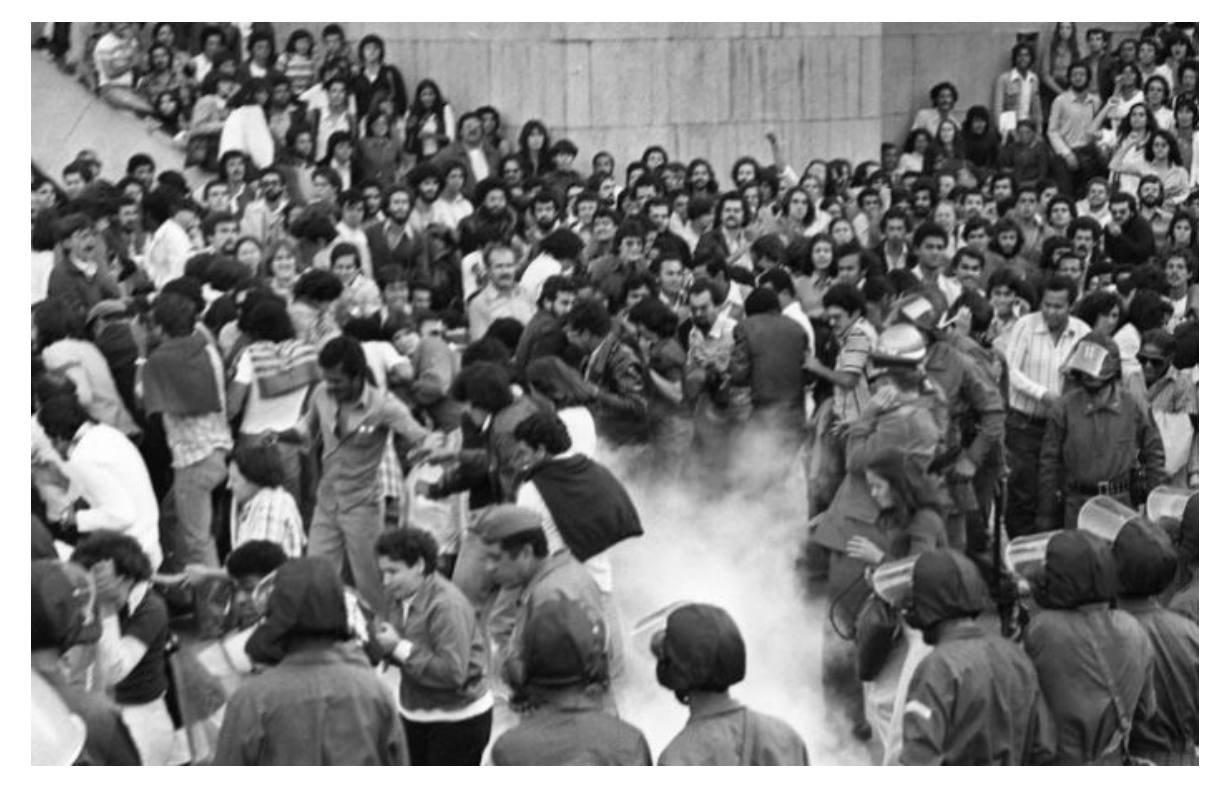

FIGURA 2.8 - Manifestação do Movimento Custo de Vida na Praça da Sé em São Paulo.

FIGURA 2.9 - Manifestação do Movimento Custo de Vida na Praça da Sé, em São Paulo.

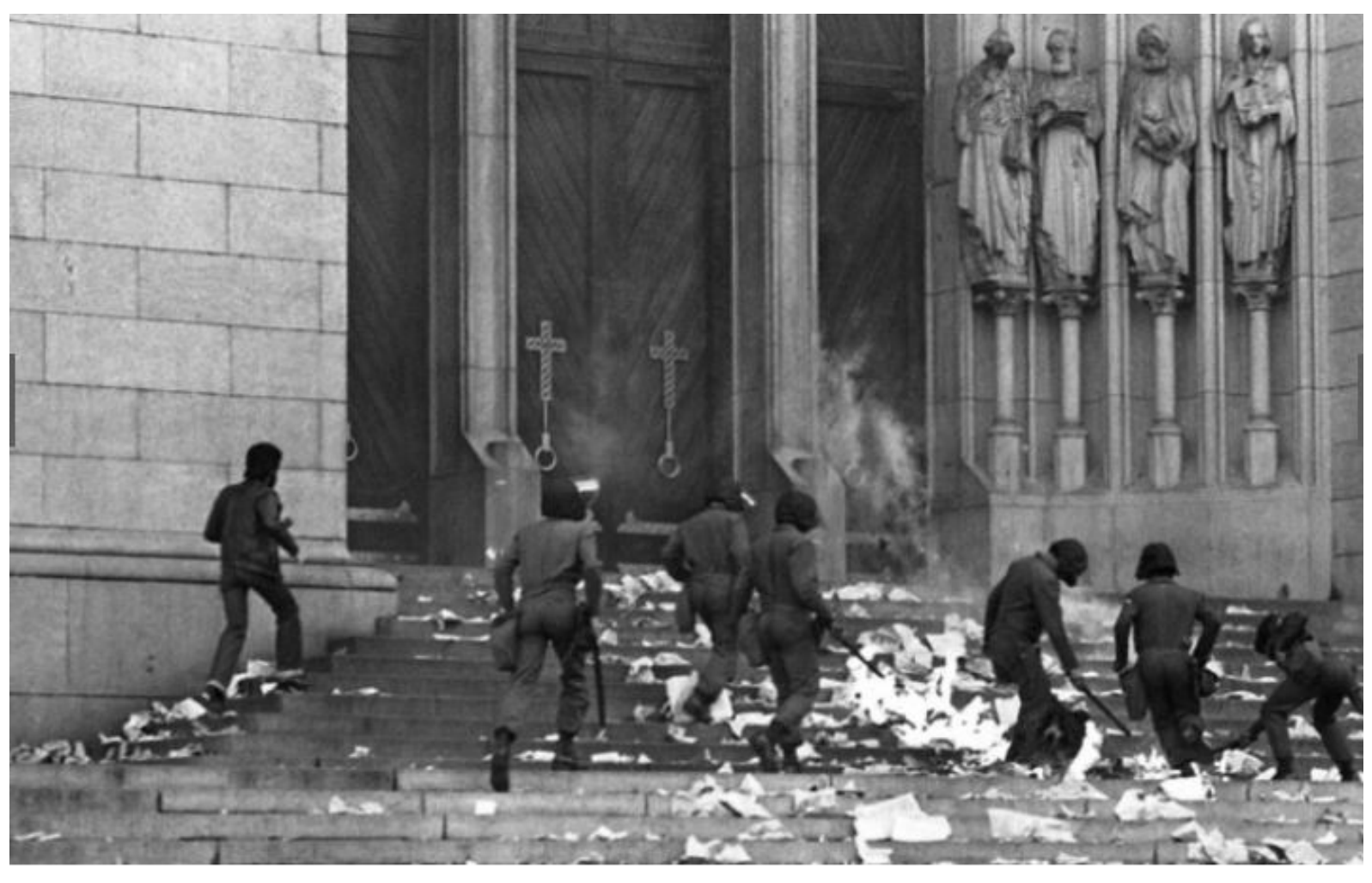


O êxito das CEBs, expressado, por exemplo, a partir da importância do "Clube de Mães" e do MCV, se deu porque partiam da realidade concreta da luta do povo. Nesse sentido, é importante enfatizar que as CEBs eram políticas, não no sentido partidário, mas porque se constituíram como um espaço de expressão do povo oprimido, de onde emergiu a consciência crítica do povo contra a ordem social injusta. Do contrário seria aprofundar a mentalidade dominante na consciência do oprimido, "seria uma inversão de seu papel de descodificadora da consciência do oprimido para tornar-se legitimadora de uma igreja neocristandade, ${ }^{62}$ vinculada aos interesses dos proprietários dos meios de produção e mediatizada em sua relação social pelo Estado burguês" (BETTO, 1985, p. 32).

\subsection{POSTURA EXTRA-ECLESIAL: O MÉTODO}

As CEBs adotaram duas posturas, simultaneamente: uma postura intra-eclesial, vinculada aos ritos e eventos religiosos; e uma extra-eclesial, a partir da sua vinculação com as lutas populares. Nesse sentido é importante abordar a relação entre o agente pastoral e os membros da comunidade, pois muitas vezes os agentes pastorais assumiram uma postura colonialista, pois pretendiam ensinar aos membros o que "era bom para o povo". Foi através da prática que perceberam esse equívoco, perceberam que a liderança deveria ser mais coletiva do que pessoal, mais flexível do que institucional, em um permanente aperfeiçoamento. Procuravam estabelecer um relacionamento solidário e fraterno entre os membros, a partir de um modelo democrático de autogestão. Do contrário, seria uma falsa participação, que mantinha a ordem dominante, onde seria possível mudar as pessoas que ocupam o poder, mas sem modificar sua estrutura. Tanto o clero quanto os leigos enfrentaram o desafio de redefinição de papéis tradicionais, em busca de novos modos de se relacionar que superasse o verticalismo e a autoridade eclesiástica.

62 "Cristandade: periodo da ldade Média em que a Igreja tinha hegemonia politica na sociedade. Neocristandade: a Igreja cuja estrutura institucional se apóia no aparelho politico e administrativo do Estado" (BETTO, 1985, p. 32 grifos do autorl.
Portanto, é preciso que nos reeduquemos ao pretender educar as classes populares. É preciso despojarmos-nos das categorias acadêmicas e dessa "erudição" europeizada, das categorias acadenicas e dessa "erudiça europeizada, cartesianamente destilada em conceitos claros e precisos, como se o real fosse o que existe em nossa cabeça (BETTO,
1985, p. 37).

A partir do método ver-julgar-agir, ${ }^{63}$ que tem como ponto de partida o chão da realidade, buscavam, em comunhão, a libertação do povo oprimido a partir de ações. Nesse sentido, é importante destacar os métodos de ensino de Paulo Freire na ação das CEBs a partir da pedagogia do oprimido.

Para Freire (2019 [1968]), nas sociedades governadas pelos interesses de grupos, classes e nações dominantes, a educação como prática da liberdade postula necessariamente uma pedagogia do oprimido. Não uma pedagogia para ele, mas que advém dele. A prática da liberdade só encontra expressão adequada numa pedagogia em que o oprimido tenha condições de descobrir-se e conquistar-se como sujeito de sua própria determinação histórica (FREIRE, 2019 [1968]). Esta pedagogia deveria basear-se no processo de conscientização, feito à medida em que a prática corresponda às ideias e ao contato permanente, no qual todos se (re)educam.

Durante esse processo de construção de uma nova pedagogia, os agentes pastorais perceberam que seus discursos, quase sempre, eram apropriados pela ótica das classes dominantes. Sendo assim, foi fundamental resgatar as dimensões libertado-

63 Com esse método "se pretende efetuar uma reflexão crítica e voltada para a prática, de modo que as privações vividas deixem de ser consideradas como fatalidades. O "ver" consiste numa sucessão de observações de cada um dos presentes sobre o tema em questão [...] O objetivo é, do confronto das observações, caminhar das impressões superficiais para uma compreensão mais objetiva e que relacione o fato com suas causas. $\mathrm{O}$ momento do "julgar" implica o contraste entre a realidade observada e os valores do cristianismo. [...] Os fatos da realidade são julgados por uma exigência ética, na medida em que a "palavra de Deus" é trazida para o plano do vivido presente. Finalmente, no "agir" trata-se de concluir sobre aquilo que aquelas pessoas poderiam fazer diante do problema" (SADER, 1988, p. 159-160). Sobre o método, ver: (BORAN, 1977). 
ras do discurso evangélico, evitando o populismo eclesial ${ }^{64}$ ou o vanguardismo eclesial ${ }^{65}$ (BETTO, 1985).

Sader (1988) relata que em 1971 formaram equipes de "educação popular" na periferia sul da cidade de São Paulo, com intuito de promover a alfabetização segundo o método Paulo Freire, proibido durante o regime militar. Com isso, posicionaram-se contra outras iniciativas que não se preocupavam com a participação ativa e consciente da população. Para os educadores, a alfabetização era um meio para a formação da consciência crítica no interior das coletividades auto-organizadas. Segundo o autor:

Por tal método, o aprendizado da leitura e da escrita é inseparável do uso que se faça desse instrumental na vida prática e, postulando um despertar crítico do educando, elo se dá vinculado à tomada de consciên cia das condiç̃es de vida a ca elaboração coletiva de projetos de auto-organização. O método pressupōe um "saber popular" que requer categorias para ser elaborado, opondo-se assim a uma concepção da educação como simples inculcação de um saber em seres puramente ignorantes (SADER, 1988, p. 148).

A procura por esses cursos de alfabetização era enorme e os educadores partiam daí para despertar outras motivações dos participantes. Com isso, começaram a surgir por toda parte grupos de educação popular que se somavam aos grupos de jovens, clubes de mães, grupos de noivos ou de casais, todos inspirados nas reflexões da Igreja "pós-conciliar".

Assim, as CEBs se espalharam como uma rede em nível nacional. Porém, os núcleos eram muito heterogêneos, oscilando

64 "O populismo eclesial é a atitude dos agentes que sacralizam o povo. como se tivessem consciência pura, isenta de influência de qualquer influênconscientizar e de line. Acredian que o povo, por si so, écapaz de se

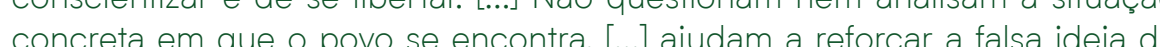
que a pobreza é uma virtude agradável a Deus. Encobrem desta forma verdadeira causa da pobreza que é a contradicão entre capital e trabalho. Esquecem-se de que a Palavra de Deus aponta a pobreza como sinat de.

65 "Vanguardismo eclesial é a atitude dos agentes que julgam o povo incapaz, ignorante e se julgam autossuficientes no encaminhamento da pastora popular. Acredita esta tendência que nada tem a aprender com o povo l.... convencidos de que a "ciência" que liberta se elabora fora do povo para ser depois nele introjetada. [.... Esta tendência resulfa de uma formação elitista, eivada na crença de que a história é feita por quem detém o poder” (BETTO, 1985, p. 44). entre níveis mais altos e mais baixos de consciência do seu papel histórico. Entre os motivos de seu êxito, é possível destacar o caráter flexível de sua forma organizativa, a construção de um espaço de reconhecimento pessoal para seus membros, no acolhimento das formas da religiosidade popular. E seu próprio êxito significou que a prática das CEBs não se conteve nos ditames eclesiásticos iniciais.

É importante destacar que, apesar da incidência das CEBs urbanas, foi na zona rural que mais se proliferaram, pois tinham articulação com a Comissão Pastoral da Terra, ${ }^{66}$ acompanhando os problemas e conflitos existentes para além das cidades. As experiências de luta, construídas a partir das comunidades, contribuíram também para o nascimento, em 1984, do Movimento dos Trabalhadores Rurais Sem Terra. As comunidades tornaram-se lugares de discussão e conscientização para a construção de um espaço político de confronto na luta pela terra. Em 1981, Frei Betto calculou em 80 mil o número de CEBs, congregando cerca de 2 milhões de pessoas em todo o país.

Com a modificação da conjuntura política nacional e a "abertura política" dos anos 1980, as CEBs já não eram mais o espaço privilegiado de organização popular. Com as novas vias de participação social e política, seu alcance cada vez mais foi sendo reduzido e foi preciso aceitar a modificação no papel que desempenhavam, sem que isso diminuísse o trabalho realizado e o importante papel que tiveram na redemocratização.

Para Frei Betto (1985) essa mudança não significou que estivessem superadas, pois a Igreja está fadada a desempenhar, enquanto comunidade cristã, um papel decisivo no futuro da sociedade. Nesse sentido, deverá refletir sempre sobre a postura que adota, pois ao legitimar e sacramentalizar a ordem estabelecida, a Igreja contribui para a neutralização da luta do povo por sua libertação, ou ao exercer sua missão profética de denúncia, ajudará o povo na sua libertação.

66 O surgimento da Comissão Pastoral da Terra (CPT) ocorreu de forma oficializada em 1975, durante a XIV Assembleia Geral da CNBB. Inúmeros fatores socioculturais e politicos permitiram o seu surgimento no seio da Igreja Católica. Vale destacar, em sintese, a moderna doutrina social da Igreja, que possibilitou a formação da CPT enquanto ação pastoral; e a politica agrária durante o periodo do governo militar, que criou a necessidade de se instituir um órgão com as características da CPT. 


\subsection{O DESTINO DAS CEBS}

Em um processo de democratização do país, a sociedade civil deverá refazer, de maneira independente das instituições religiosas, os organismos próprios de classes e segmentos profissionais. Provavelmente esta ação da Igreja, como os estímulos ao movimento sindical, a preocupação com o custo de vida, as lutas pelas melhorias urbanas, que foi em sua própria terminologia cunhada de "supletiva", terá esgotado seus objetivos e superado sua oportunidade histórica. O que importa indaga não é se a Igreja pode ou deve continuar essa tarefa "supletiva", apoiando e, por vezes, substituindo instituições e movimentos de natureza não religiosa. Relevante para a construção da de moracia no pás sera resposta do catolicismo ao desafio do mocracia no pais será a resposta do catolicismo ao desafio do antagonismo das classes sociais e sua disposiçáo em manter. instituições representativas e por sua luta (BRANT, 1980, p. 20).

Atualmente, as CEBs continuam a representar um papel importante, principalmente no que se refere à articulação entre fé e política. É importante destacar que após a redemocratização já não caminhavam mais "no mesmo sentido", pois elas correspondiam aos estágios de consciência e aos critérios políticos adquiridos durante os anos 1960 a 1980.

Com a redemocratização, os agentes pastorais se deram conta de que as comunidades eclesiais tinham limites e que não cabia a elas assumir por completo o processo de mudança social e política. No contexto de bloqueio dos canais institucionais de representação popular e de imensa repressão, contribuíram para as diversas formas de organização, mas as condições gerais que permitem assegurar a dignidade humana estão fora do alcance das comunidades (CAMARGO et al., 1975). A sociedade civil brasileira adquiriu nova configuração, bem como mudanças no interior da Igreja Católica, sendo que o movimento popular e o movimento operário se emanciparam das pastorais, ou seja, uma prática política inteiramente desvinculada da prática pastoral. Assim, a pastoral popular já não era o núcleo hegemônico de organização da base.

Camargo, Souza e Pierucci, em 1980, já expressam os desafios que as CEBs enfrentavam por estar em meio às determinações econômicas e sociais do capitalismo. Os autores afirmam que seria ilusório crer que as comunidades persistiram como matriz de organização capaz de influenciar de modo radical a sociedade como um todo, permanecendo ilhadas aos determinantes de uma sociedade capitalista e aos obstáculos impostos por tal sistema. Como relata Evaniza Rodrigues, ${ }^{67}$ naquele momento existia uma relação intrínseca entre movimento social e igreja, que pouco a pouco foi se desfazendo:

A igreja acabou sendo uma forma de encontrar, de se encontrar essas diferentes ações que viravam movimento. Mas não tinha uma assim: aqui é a reunião do movimento, aqui é a reunião da pastoral, era uma coisa muito misturada. Depois, com um certo tempo, foi complexando as coisas e aí a pastoral assumiu uma tarefa muito mais formativa, de apoio a grupos novos que não tinham tanta estruturação, tanta organização, né? (RODRIGUES, 2O21, s/p)

A Igreja passou a ter um papel de formação que contribuiu na forma de pensar o movimento mais coletivamente, bem como respaldando o movimento quando necessário. Como por exemplo membros da Igreja, como os bispos, participando de reuniões de negociação com poder público e participando do cotidiano do movimento, em manifestações e atos públicos, representando um respaldo institucional importante para o movimento.

Assim, era uma coisa do cotidiano mesmo, da vida, do movimento, das negociações, a igreja fazia parte disso, né? Hoje, você tem uma relaçăo que é muito mais distante, né? Mudou o movimento e mudou a igreja, as duas, os dois mudaram. Tanto o movimento adquiriu muito mais autonomia, muito mais estrutura e, inclusive, tem voz própria, né? Como também a igreja num é mais aquela igreja, né? Embora o Papa Francisco tá tentando bravamente, né? (RODRIGUES, 2O21, s/p.)

67 Evaniza Rodrigues, membra da União Nacional por Moradia Popular (UNMP), em entrevista conta que sua inserção no movimento social de moradia se deu a partir da sua atuação nas pastorais, já que da Pastoral da Juventude passou a fazer parte também da Pastoral de Moradia. Em meados da década de 1980, quando tinha aproximadamente 13 anos, teve contato com a igreja progressista, onde existia forte articulação entre fé e politica de maneira que “tinha reunião que você não sabia se era reunião da igreja, de politica, da associação de bairro, podia ser qualquer coisa... ai a reunião era a mesma, né, as pessoas, mesmo lugar, mesmas paułas, né." Evaniza relata que a Pastoral da Moradia contribuiu para a fundação da União e faz questão de mencionar a importância do padre Ticão, "grande articulador do movimento popular, que era o movimento Sem Terra Leste 2", falecido durante o desenvolvimento desta disserłação, em janeiro de 2021, a quem presto assim uma singela homenagem, já que é impossivel retratar a história da igreja em comunhão com a luta do povo sem mencionar o seu nome. Sanchez et. al., explica como se deu a formação da UNMP: “Em 1978, com a dinâmica das reivindicações e lutas a melhoria da qualidade de vida levaram à criação da União dos Movimentos de Moradia (UMM) que organizou os múltiplos movimentos pelo direito à moradia digna em uma organização coletiva mais unificada, com a ascensão politica do Partido dos Trabalhadores" (SANCHES; STEVES; PIOTTO, 2019, p. 426 . 
Ainda que existam importantes iniciativas e parte da Igreja que se coloca em comunhão com a luta do povo, é possível afirmar que pouco a pouco os movimentos se "profissionalizaram", de maneira que a lgreja deixou de ser o espaço único das organizações populares de base, como também o movimento foi assumindo esse papel de formação nas últimas décadas, emancipado das pastorais.

Mesmo com tamanhas modificações, para Selvino Heck (2020, p. s/p. $)^{68}$ a presença e atuação das CEBs continua a fazer sentido, já que apesar de o Brasil viver tempos democráticos, são muitos os desafios para as CEBs e vários deles iguais aos tempos de ditadura. Para ele, em tempos de crise econômica, social, cultural, ambiental e de valores, as CEBs "continuam sendo semente e fermento de transformação da sociedade e fazendo história", bem como "continuam sendo resistência e esperança, apontando para a utopia e o Reino já a partir deste mundo", mas que agora carregam pautas como empoderamento dos povos originários, da juventude (sobretudo negra) e das mulheres em todos os espaços da lgreja e da sociedade, pois "basta de feminicídio, basta da extermínio de jovens, basta de extermínio de negros e indígenas". Assim como Evaniza, ele reforça a importância dos ensinamentos do Papa Francisco e acrescenta que tempos de pandemia é tempo em que a solidariedade e compaixão afloram, tão presentes nas CEBs, já que em suas palavras:

As CEBs continuam na base, ałuam pela base e são de base. Em tempos de perda de direitos e ameaças a democracia, esfão do lado certo da história, amparadas nas palavras e gestos do Papa Francisco, e no seu compromisso de fé, em primeiro ugar com os mais pobres, com os esquecidos da história, e, partir daí, lutando por transformação social, por justiça, liberdade, igualdade (HECK, 2019, s/p.).

68 Selvino Heck é militante das CEBs, foi assessor do $28^{\circ}$ Encontro de CEBs da Arquidiocese de Porto Alegre e Deputado estadual constituinte do Rio Grande do Sul (1987-1990). Atualmente é membro da Coordenação Naciona do Movimento Fé e Polifica. Em junho de 2020 realizamos importante conversa para o desenvolvimento desta pesquisa, que resultou no seguinte texto: hitps://sul21.com.br/colunasselvino-heck/2O2O/06/a-cidade-e-a-universidade-na-boa-luta/. Acesso em 29 de junho de 2021.
Peterson Prates (2019)69 compartilha dessa visão, afirmando que as CEBs continuam vivas, porém aponta a necessidade de entendê-las com os olhos do tempo de agora, não de outrora, a partir dos clamores dos dias de hoje. Segundo ele, não se pode subestimar o papel que as Comunidades Eclesiais de Base desempenham hoje, tanto no Brasil quanto na América Latina. É preciso superar o saudosismo do contexto de surgimento das CEBs, celebrando esse importante momento como memória, mas entendendo que tinham um perfil que correspondia àquele tempo.

Para Prates (2019) a busca pela libertação depende do local onde as CEBs estão inseridas. Por exemplo, se estão vinculadas a uma Paróquia cuja perspectiva é a "Igreja em saída", as comunidades também terão essa conduta. Esse é um fator eclesial que contribuiu para a diminuição das CEBs, fenômeno que chamou de "paroquialização". Se antes as comunidades se auto-organizavam, agora a organização foi centralizada em torno das paróquias, enfraquecendo, assim, a autonomia e a mobilização popular. Em muitos locais a paroquialização tirou o potencial auto-organizativo das comunidades, com o pároco, muitas vezes, tendo a primeira e a última palavra. Portanto, este é um fator que desarticulou muitas comunidades, já que seus membros não conseguiam mais tratar de assuntos sócio-políticos com viés transformador. Segundo ele:

Tínhamos redes de comunidades em determinadas áreas pastorais, semi autônomas, que estavam inteiramente em comunhão com o programa das suas Dioceses, só que conduzidas por suas lideranças leigas. Ao longo do tempo, essas áreas foram sendo divididas, com a criação de Paróquias e, assim, concentrando o poder no que a gente chama de matriz, deixando as comunidades que antes tinham a sua vida própria também como meras capelas de bairro, que servem para aos domingos ter celebração. Ou seja, foi se desconfigurando, porque ali na comunidade era o espaço de todos se reunirem na celebração da palavra da eucaristia da escuta e da meditaça lebrçao da palavra da eucaristia, da escuta e da medifação,

como também para círculos bíblicos, reuniões da associação

69 Realizei também uma entrevista com Peterson Prates, coordenador da Comunidade Eclesial de Base em Sapopemba e membro da Economia de Francisco, na qual reforçou que é preciso levar para as CEBs a discussão de questões estruturais. Afirmou que sente-se motivado a participar desse movimento justamente para levar discussões como a Economia de Francisco para os encontros das CEBs. O que não é algo fácil, muito menos rápido, já que as mudanças acontecerão a partir do desencadeamento de processos, no entanto se sente esperançoso com o chamado do Papa Francisco. 
de bairro e discutir reivindicações populares. Era o espaço que a comunidade usava para tudo (PRATES, 2019, s/p.).

É possível afirmar que ainda permanecem com as duas posturas: intra-eclesial, com os ritos religiosos, círculos bíblicos, grupos de rua, celebração da palavra e extra eclesial, já que permanecem vinculadas à realidade do território que estão inseridas. Apesar de manter a postura extra-eclesial, as lutas atuais são mais pontuais, territorializadas e autocentradas. As reivindicações se referem, sobretudo, à manutenção e demandas dos bairros em que estão inseridas, como a eleição de conselhos ou a instalação de um ponto de ônibus. Quando as reivindicações são atendidas, a comunidade tem a impressão que a luta acabou, quando na verdade esquecem que esta deveria ter um caráter estrutural, de maneira que para Prates (2019) parece que uma luta mais estrutural está mais distante do diálogo com as comunidades e talvez mais distante da Igreja em si.

As comunidades são muito ligadas ao território e se antes eram basicamente dois os motivos que uniam os membros das CEBs

- a expropriação da terra e a exploração do trabalho -, agora essas duas pautas estão mais na memória do que na voz do povo, por mais que sejam causas ainda tão presentes na sociedade brasileira. Questões mais estruturais como essas são pouco ou nada discutidas. Para Prates (2019), o convite do Papa Francisco para se pensar em uma nova economia é uma oportunidade para esse tipo de debate:

Por isso tem esse convite do Papa, para que a gente discuta estrutura. Para reinventar e redescobrir também nas comunidades o jeito de discutir estrutura. Porque as CEBs já discutiram isso, mas o processo que foram vivendo, a ms já discurran isso, ma do e conjuntura do pais, fez com que isso sumisse. Então, se a gente lembrar o que as comunidades cantavam naquele período numa crítica econômica estrutural: "na terra dos homens formada em pirâmides há poucos em cima e muitos na base / na terra dos homens formada em pirâmides os poucos de cima esmagam a base / oh povo dos pobres, povo dominado que fazes aí, com um ar tão parado / o mundo dos homens tem de ser mudado, levanta-te povo, não fiques parado / na terra dos homens formada em pirâmide viver não se pode, pelo menos na base / o povo dos pobres que vive ha pai fazer cair a velha pirâmide / e a terra dos homens já sem a pirâmide pode organizar-se em fraternide jám é piramide pode organizar-se em fraternidade / ninguém, é esmagado na nova cidade todos dão as mãos em viva unidade"(PRATES, 2019, s/p.).
Portanto, apesar de não ter sido a primeira vez na história brasileira em que a lgreja Católica se engajou na prática cotidiana junto ao povo, ${ }^{70} \mathrm{com}$ as CEBs a Igreja Católica se inseriu num quadro de uma alteração da sua maneira de agir e se relacionar, não mais para mas com o povo oprimido. Assim, com esse histórico pretende-se recuperar o protagonismo do poder local e o trabalho realizado com a mobilização popular no território, no chão da realidade, tendo como pressuposto o reconhecimento de que a prática popular é capaz de criar um projeto alternativo de sociedade, onde a mudança se dará pela ação coletiva. Como também, a importância do trabalho de base que contribua e fortaleça na luta cotidiana dos moradores, com reconhecimento dos moradores de periferias como sujeito político histórico e de que tais territórios expressam resistência à mercantilização da cidade. Entender o contexto do surgimento e ápice das CEBs é fundamental não somente para entender a sua atuação e importância, mas também para entender as mudanças que ocorreram nas décadas seguintes.
70 E possivel citar como exemplos anteriores a atuação da lgreja Católica em territórios populares: a Fundação Leão XIII (1947) e, sob iniciativa de D. Helder Câmara, a Cruzada de São Sebastião (1955). A partir dos anos 1950 até o final dos anos 1960, Valladares (2005) mostra que é construído um novo período da produção de representações e de conhecimento sobre as favelas. Destaca duas principais características dessas produções: (1) valorização da favela enquanto comunidade; (2) inicio do trabalho de pesquisa de campo, a partir dos métodos das ciências sociais. A partir desse periodo a favela entra em cena nas ciências sociais e tem contribuição de estudos como os de Padre Lebret, Arthur Rios, Anthony Leeds, Lucien Parisse e Luiz Antonio Machado da Silva. 


\section{ENTREMEIOS:}

breve contextualização das periferias

\subsection{ANOS 1970-1980: O CONTEXTO DAS CEBS}

A década de 1970, contexto de regime militar, foi marcada por uma paisagem urbana paulistana onde os empobrecidos residiam nas franjas da mancha urbana, as conhecidas periferias. ${ }^{71}$ Caracterizadas como, em geral, territórios desprovidos de infraestrutura, dissemelhantes das regiões centrais da cidade, onde residiam as classes média e média-alta. (Figura 3.1). ${ }^{72}$

De 1950 a 1980 a população urbana passou de 36,00\% do total para $67,50 \%$, sendo as periferias paulistanas resultado das condições de precariedade e segregação sócio-territorial (Gráfico 3.1). Mas seria um engano pensar que esse crescimento foi desordenado e caótico por falta de planejamento, como comumente é dito. Existia uma lógica nessa aparente desordem: expansão de modo concêntrico de periferias autoconstruídas pelo território (FELTRAN, 2018).

Na realidade, a lógica da desordem era econômica, já que foi com os baixos salários que os trabalhadores tiveram que prover suas moradias. Segundo Camargo et. al. (1975, p. 22), "a aparente desordem do crescimento da cidade encobre, no entanto, a organização da sociedade. Por trás dos 'problemas urbanos' está a vida dos habitantes da cidade, que se organiza na repartição dos benefícios do desenvolvimento e na distribuição do preço a pagar". 


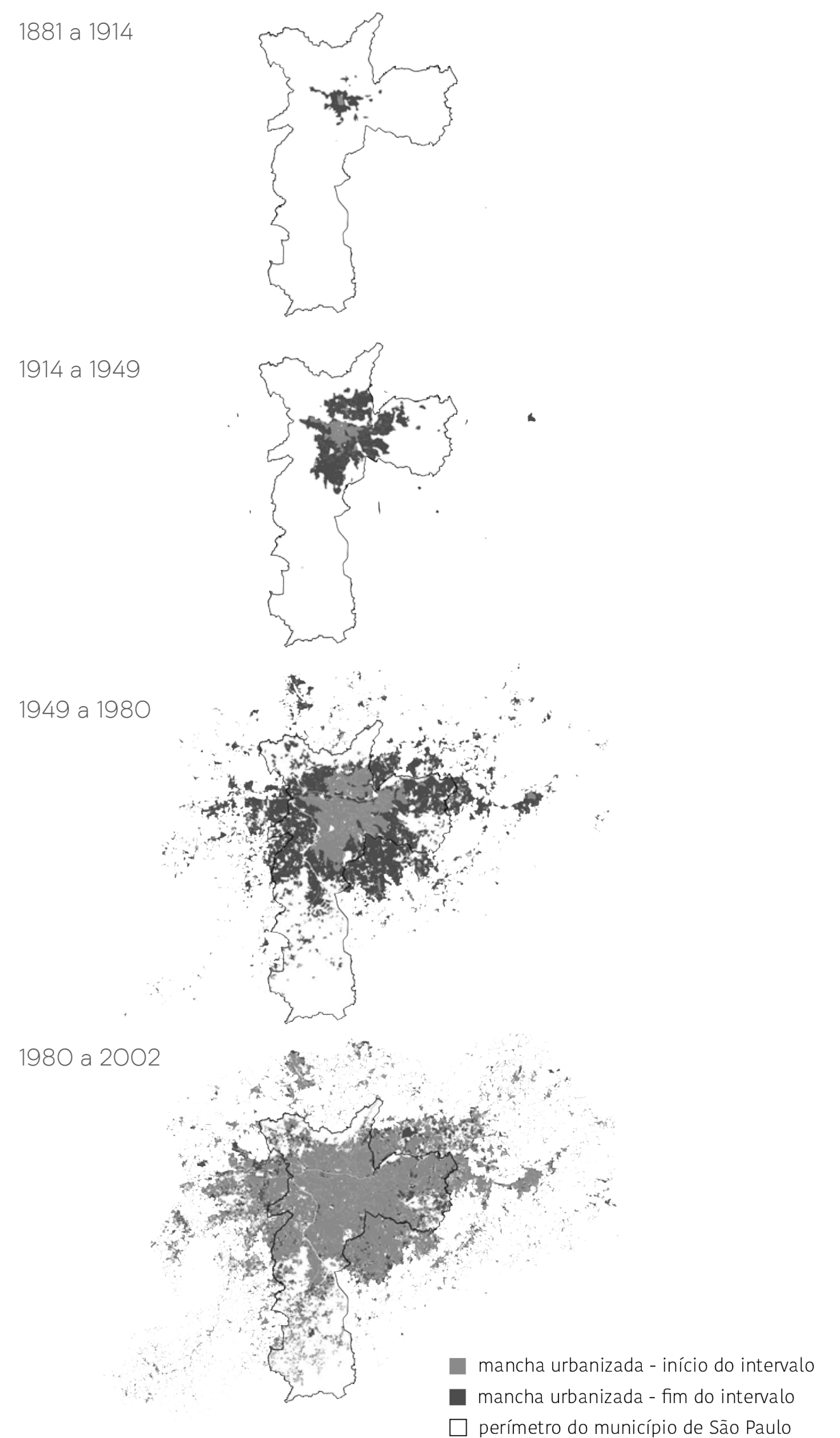

FIGURA 3.1 - Evolução da mancha urbana de São Paulo.

To do município de São Paulo

ONTE: LOPES, 2018, p. 39 .

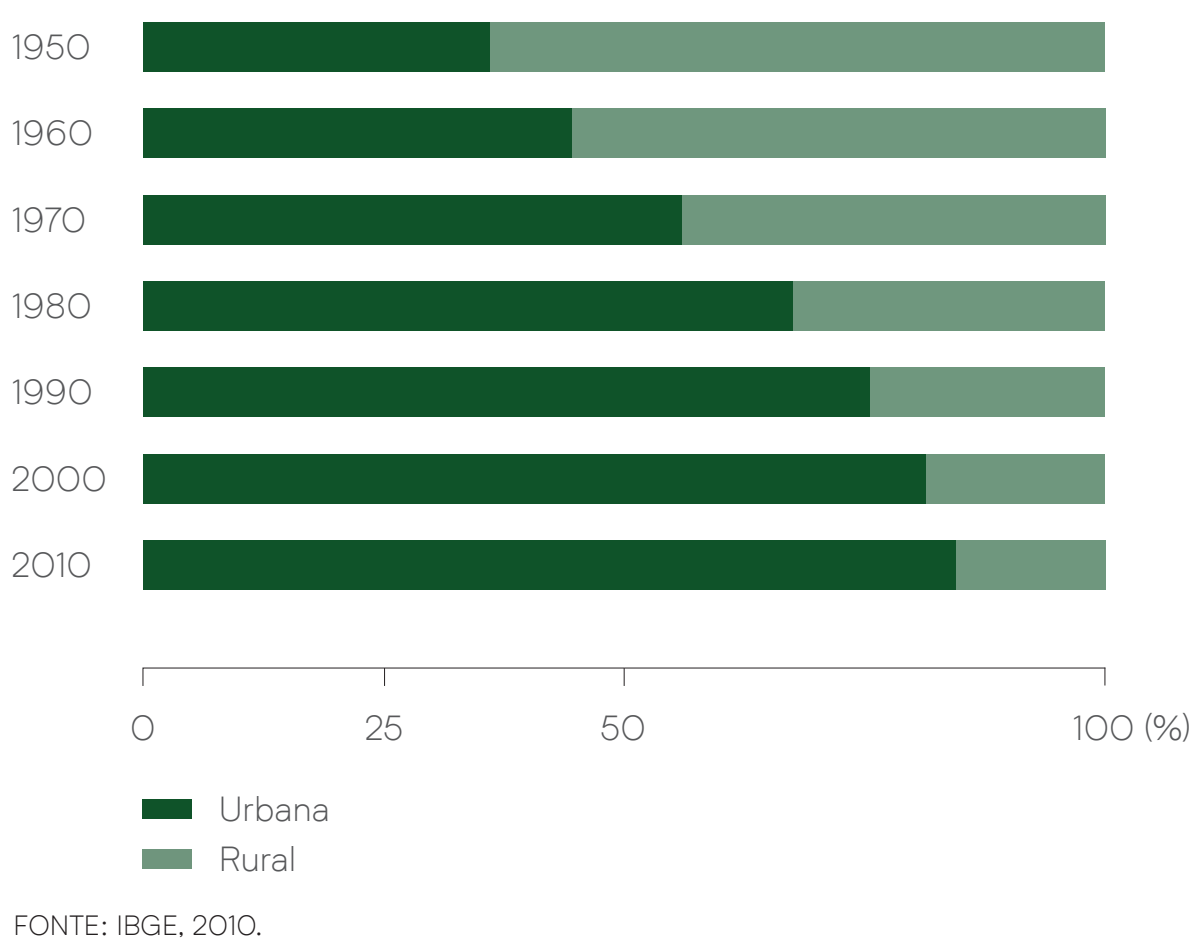

FONTE: IBGE, 2010.

Se por um lado as periferias demonstram o desequilibrio na construção das cidades, por outro, são territórios de resistência e de mobilização popular às condições de precariedade e segregação impostas às periferias, sendo assim uma forma de produção de cidade, como explica Mautner:

Com uma larga maioria da força de trabalho trabalhando por salários que mal asseguram sua reprodução, não é surpreendente que a moradia jamais tenha entrado na 'cesta básica' enquanto mercadoria a ser adquirida no mercado, com seu valor, portanto, incorporado ao salário. O efeito disto é sentido claramente tanto na produção de edificações - a indústria da construção - quanto na produção do espaço urbano (MAUTNER, 1999, p. 255, grifo meu).

Nesse contexto, a autoconstrução foi a solução possível para a população excluída do mercado imobiliário e não atendida por políticas públicas. Esse processo é descrito por Maricato como urbanização de baixos salários, pois "nem os salários pagos pela indústria e nem as políticas públicas de habitação são suficientes para atender as necessidades de moradias regulares, legais" (MARICATO, 1996, p. 43). Oliveira (2003 [1972]) faz uma análise do papel da autoconstrução na intensidade de exploração da força de trabalho e sua relação com a acumulação de capital. Portanto, trata-se do "produtivo excluído", pois nem o 
trabalhador do chão de fábrica conseguia arcar com os custos de moradia no mercado imobiliário capitalista. Isso combinado a um contexto dos investimentos públicos que favoreciam a infraestrutura industrial e o mercado concentrado e restrito (MARICATO, 1996). ${ }^{73}$

Como se trata de um contexto de industrialização, a moradia e entendida como a base para a reprodução da força de trabaIho, onde o trabalhador passa o tempo de recomposição necessário em função da produção capitalista (SADER, 1988). É, portanto, um período de expansão periférica capitalista, combinada com desigualdades e oferta limitada de serviços públicos (FELTRAN, 2O14).

Em geral, as periferias eram formadas por famílias extensas, católicas, de maioria migrante, que constituíram o chão de fábrica, ou seja, operários em um período de industrialização do país. Migrantes que trouxeram consigo o sonho de uma melhoria de vida, ancorada no trabalho e na conquista da casa própria. Esse "sonho da casa própria" fez com que, a partir dos seus parcos recursos, muitos finais de semana e qualquer descanso dos trabalhadores fossem sacrificados para ir "tocando a obra" de suas casas. ${ }^{74}$ Segundo Bolaffi (1982 [1975]), na década de 1960 a casa própria era a principal aspiração das populações urbanas brasileiras, pois a aquisição do imóvel era considerada "evidência de sucesso".

Se da porta para dentro o cenário era da autoconstrução, o que evidenciava o sonho da casa própria, da porta para fora decorria a desestruturação e reconstrução do público (SADER, 1988). O autoritarismo presente no contexto de ditadura militar não deve ser apenas entendido como prática do Estado contra a

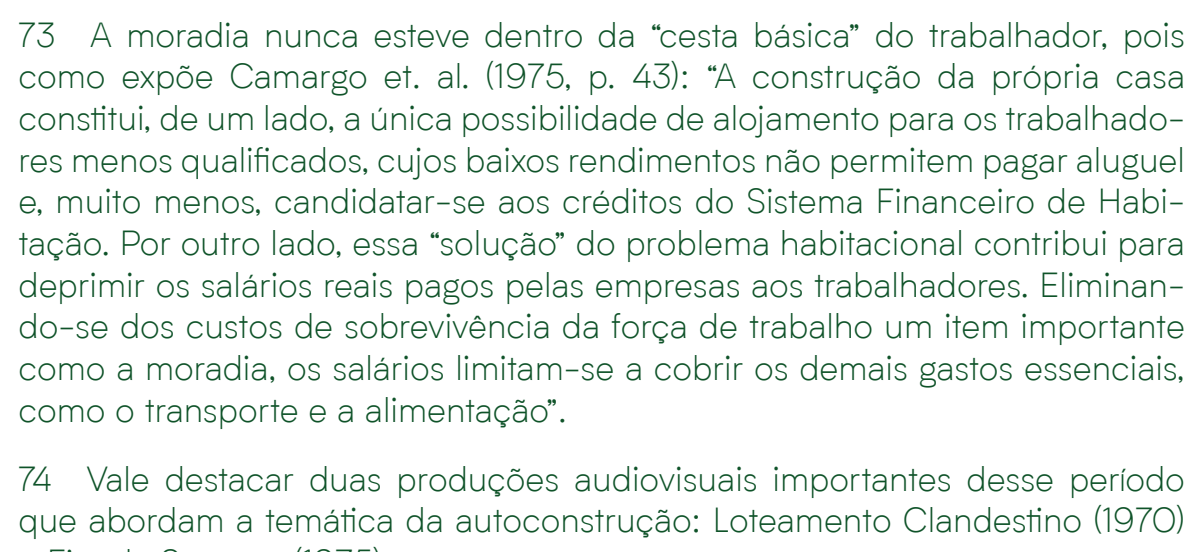
como expõe Camargo et. al. (1975, p. 43): "A construção da própria casa

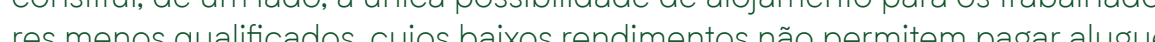
e. muito menos, candidatar-se aos créditos do Sistema Finn pagar alugue tacão Por outro lado, essa "soluc̃a”" do problema habitacional contribui para deprimir os salários reas pasos pelas empresas aos trabalhadores. Eliminando-se dos custos de sobrevivencia da forç de trabalho um item importante como a moradia, os salários limitam-se a cobrir os demais gastos essenciais.

74 Vale destacar duas produções audiovisuais importantes desse periodo que abordam a temática da autoconstrução: Loteamento Clandestino (1970) e Fim de Semana (1975). sociedade, mas como uma prática social tornada experiência cotidiana. O efeito dessa estratégia era:

apagar os sinais de reconhecimento popular e esvaziar o sentido da ação coletiva como forma de participação na vida social (...) 'despolitizar' a sociedade e desfigurar a política como coisa pública (SADER, 1988, p. 115).

Nesse período houve o fechamento de diversos espaços públicos: praças, parques, botequins, como também quarteirões inteiros desaparecem, acabando com espaços de convivência importantes para os encontros cotidianos na cidade. ${ }^{75}$ Também os conflitos sociais eram ofuscados e reprimidos, pois as ações coletivas eram consideradas sinais de desordem e perigo. Parte do espaço público, portanto, se dissolveu fazendo com que os indivíduos ficassem mais na esfera privada e buscassem novos espaços para se organizarem.

\subsubsection{MATRIZES DISCURSIVAS: QUANDO NOVOS} PERSONAGENS ENTRARAM EM CENA

Em São Paulo, entre 1970 e 1980, a saga dos movimentos sociais populares possibilitou a criação das condições para a reconquista da democracia. ${ }^{76}$ Apesar dessas décadas terem sido marcadas pelo fervor dos movimentos populares, é importante enfatizar que a emergência dos movimentos se deu de maneira fragmentada. Brant (1980) explica que isso aconteceu por ser um período de extrema repressão da expressão política popular,

75 O Elevado Costa e Silva, popularmente conhecido como Minhocão, foi construido nesse periodo (1971) e exemplifica de forma muito clara esse processo de desestruturação citado. Foi resultado de desapropriação e desarticonveços públicos de convivência. Uma verdadeira destruição físi-

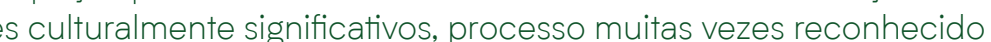
como remodelação urbana

76 Gohn (2014) explica que o movimento social usualmente tem os seguintes elementos: "demandas que configuram sua identidade; adversários e aliados; bases, lideranças e assessorias [...]; práticas comunicativas diversas [...]; projetos ou visões de mundo que dão suporte a suas demandas; e culturas próprias nas formas como sustentam e encaminham suas reivindicaçōes" (GOHN, 2014, p. 14). Como a própria autora reconhece, essa conceituação se enquadra melhor aos movimentos sociais do periodo, por exemplo, das CEBs, mas tem seus limites como definição para os movimentos sociais da atualidade. 
o que tornou difícil a centralização dos conflitos e até mesmo a comunicação permanente entre os movimentos. ${ }^{77}$ Para o autor:

Os novos movimentos sociais apresentam-se como a bas possivel de uma real democratização da sociedade, não só pelo conteúdo popular de suas reivindicações, mas também pelas formas democráticas que conseguiram criar diretamene a despeito de instituicões ditatoriais e de uma repressão sem regras nem freios (BRANT, 1980, p. 20, grifo meu).

Os movimentos são a base possível de democratização porque se trata do período em que novos personagens entraram em cena, nos termos de Sader (1988), constituindo um novo sujeito social e histórico:

Quando uso a noção de sujeito coletivo a expressão indica uma coletividade onde se elabora uma identidade e se organizam práticas através das quais seus membros pretendem defender interesses e expressar suas vontades, constituindo-se ne lutas (SADER, 1988, p. 11-12).

Para Chauí (1988), a novidade era tríplice: um novo sujeito (coletivo), lugares políticos novos (a experiência do cotidiano) numa prática nova (a criação de direitos, a partir da consciência de interesses e vontades próprias).

Para entender esse contexto, Sader (1988), se refere a três instituições - igreja, sindicato e esquerdas -, sendo que o novo sujeito nelas não encontra o velho centro, pois já não são centros organizadores no sentido clássico, e sim instituições em crise que buscaram novas formas de se reafirmar com seus respectivos públicos, sendo que segundo Sader (1988, p. 144):

1. da Igreja Católica, sofrendo a perda de influência junto ao povo, surgem as Comunidades Eclesiais de Base (CEBs)

\footnotetext{
77 O autor explica como se deu a origem dos movimentos de base: "a maior parte dos movimentos populares foi organizada de forma defensiva. Depois de destruidos ou subordinados os movimentos existentes antes de 1964, houve uma extrema vigilância do governo para evitar o surgimento de novas organizações populares. [...] A ação repressiva tinha duplo papel: de um lado, disseminava o terror, através de castigos exemplares aos opositores do regime: de outro, dificultava a articulação entre pessoas e grupos interessados nas lutas populares. O bloqueio dos canais institucionais de representação popular estimulou o uso dos laços primários de solidariedade na sobrevivência diáría da população, [.... Foi em boa parte o desenvolvimento desses laços diretos entre pessoas que confiavam umas nas outras, que deu origem a vários mo-
} vimentos de base" (BRANT, 1980, p. 13).
2. dos grupos de esquerda caçados e desarticulados pelas derrotas políticas, surge uma busca por novas formas de integração dos trabalhadores:

3. da estrutura sindical esvaziada por falta de função, surge um "novo sindicalismo".

A partir da crise dessas instituições, principalmente três matrizes discursivas marcam esse período e podem ser entendidas como sendo "modos de abordagem da realidade, que implicam diversas atribuições de significado" (SADER, 1988, p. 142). Sua importância se dá à medida que os sujeitos recorrem a elas para construir seus discursos e sua subjetivação de mundo, como explica Sader:

Nas lutas sociais, os sujeitos envolvidos elaboram suas representações sobre os acontecimentos e sobre si mesmos. Para essas reelaborações de sentido, eles recorrem a matrizes discursivas constituídas, de onde extraem modalidades de nomeação do vivido. Porque há sempre uma defasagem entre a realidade e a representação, entre acontecimento e palavra, embora não seja jamais possível depurar uma da outra, tão impregnadas estão umas das outras. Ao usar palavras feitas para nomear conflitos onde justamente se enfrentam interpretações antagônicas e se instauram novos significados, os sujeitos em luta operam mudanças de sentido nessas mesmas palavras que eles usam. Os sujeitos não são livres para produzir seus que eles usam. Os sujeitos năo são livres para produzir seus discursos e nem podem inventar na hora seus sistemas de comunicação. Eles recorrem a matrizes discursivas constituídas e, em primeiro lugar, à matriz da própria cultura instituída, reproduzida através de uma pluralidade de agências sociais (SADER, 1988, p. 142).

Dessa maneira, a crise da lgreja conduziu à reformulação de seu discurso e de sua prática, graças à matriz discursiva da Teologia da Libertação. Assim, de onde ninguém esperava, pareciam emergir novos sujeitos coletivos, que criavam seu próprio espaço e requeriam novas categorias para sua inteligibilidade. Para Sader (1988), as CEBs e essa aproximação com a luta cotidiana do povo é uma resposta para a crise de perda de influência que a Igreja Católica estava passando:

Da Igreja Católica, sofrendo a perda de influência junto ao povo, surgem as comunidades de base. [...] A matriz discursiva da teologia da libertação, que emerge nas comunidades da Igreja tem raizes mais fundas na cultura popular e apoia-se numa organização bem implantada. Beneficia-se do "reconhecimento imediato" estabelecido através da religiosidade popular (SADER, 1988, p. 146). 
Já Camargo et. al. (1975) mostra o papel das CEBs na luta pelos direitos, sobretudo dos empobrecidos, em um contexto em que muitas vezes a experiência religiosa se dava pela busca por um refúgio diante da dureza das condições de vida de grande parte da população brasileira.

Em outro plano, surgem sinais no interior da Igreja Católica de uma superação da tradição conservadora, que revelam $n a$ presença atuante em defesa dos direitos humanos e dos valores morais do cristianismo. Especialmente entre os trabalhadores, mas também em meio aos jovens e em outros grupos sociais, a presença da pastoral católica tem propiciado não só as novas modalidades de convívio nas "comunidades de base" como uma das poucas possibilidades de expressão dos anseios de justiça (CAMARGO et al., 1975, p. 150).

Por sua vez, a matriz discursiva marxista não dispõe de uma base popular como a católica, em contrapartida traz um corpo teórico elaborado e necessário para aquele período. Enquanto a Igreja proporciona "lugares públicos decisivos onde se reelaboraram as experiências populares" (SADER, 1988, p. 178), o discurso marxista dava conta de temas como exploração, lutas de classe e as condições da sociedade capitalista. Tais matrizes muitas vezes se "entrelaçam" nas trajetórias de vida dos militantes:

V. participou do movimento estudantil entre 1966 e 1969 c considera que então era quase inevitável que terminasse numa organização revolucionária. No caso foi a Ala VermeIha. Absorvia mal toda a literatura maoísta, mas se identificava com a causa dos explorados. Em 1969 quase todos os cus companheiros de organizacão foram presos. Ela

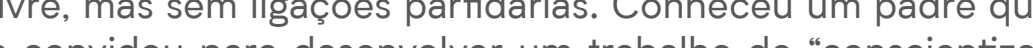
convidou para desenvolver um trabalho de "conscientização" na periferia sul, e ela foi, engajando-se a fundo na organização de cursos de alfabetização e de educação popular. Não era católica e recorria ao marxismo para a interpretação das condições sociais. Mas distanciava-se dos grupos de esquerda que participavam dessas iniciativas com o objetivo imediatista de ganhar aderentes. No interior das estruturas da lgreja encontrou espaço para sua atividade política (SADER, 1988, p. 175, grifo meu).

Já a matriz sindicalista não se baseava nem nas tradições populares (como a católica) e nem na sistematicidade teórica (como a marxista). Ela extraiu sua força do lugar institucional em que se situava, lugar constituído para agenciar os conflitos trabaIhistas, de onde advém a sua legitimidade (SADER, 1988). Essa matriz emerge a partir de transformações de dentro da prática sindical. Durante os anos 70 , passou a questionar a organização sindical e a ser reconhecida como "novo sindicalismo" ou ainda "sindicalismo autêntico". Sem amparo legal, o "novo sindicalismo" se apoiava na mobilização existente nas bases. O discurso dessa matriz vai ganhando força à medida que se ancorava nas fissuras do discurso dominante (geradas nos enfrentamentos sociais) para defender os interesses dos trabalhadores, ${ }^{78}$ mas sobretudo porque se referia aos fatos vividos compartilhados entre aquele que discursa e a quem se discursa. ${ }^{79}$

Por ser tratar de um contexto de ditadura militar, para Brant (1980) muitos dos movimentos sociais desse período surgiram a partir da necessidade de substituir instrumentos bloqueados ou destruídos pelo regime autoritário, sendo assim:

A atuação direta de aloumas comunidades de base nas reivindicações locais decorreu da impossibilidade de contar com a associação de bairro existente ou de apossar-se de sua direção. O sindicalismo paralelo de algumas oposições revela sua descrença na possibilidade de atuação autônoma do próprio sindicato, persistentemente atrelado ao Estado. Especialmente no período mais repressivo, a busca de caminhos alternativos de organização, frente aos canais oficiais de representação, afigurou-se como única possibilidade para a continuidade das utas (BRANT, 1980, p. 18).

Portanto, os movimentos sociais das décadas de 70 e 80 vão se constituindo a partir dessas matrizes para repensar o coti-

78 Exemplo disso foi a campanha pela reposição salarial em 1977. O Sindicato dos Metalúrgicos de São Bernardo solicitou um estudo do DIEESE com objetivo de denunciar a manipulaçáa dos indices oficiais da inflaçăo de 1993 mento público da manies havam peráto. Com isso, "houve o reconhecinom movimento pela

79 Como por exemplo o discurso de posse de Luiz Inácio da Silva quando assumiu a presidência do Sindicato dos Metalúrgicos de São Bernardo do Campo (1975). Lula "recorria a vários lugares-comuns para caracterizar o momento histórico, numa retórica tradicional em tais solenidades, mas já lhes dava o sentido de um compromisso de luta. [...] Ele falava da responsabilidade que assumia numa hora particularmente grave no mundo inteiro, como um desafio para todos que como nós tem um ideal maior de bem-estar coletivo. [...] É visível como o discurso vai ganhando força à medida que se refere aos atos vividos por ele e seus companheiros. E depois dessa denúncia da situação ele prevenia que não estava querendo lançar pedras ou endereçar criticas a quem quer que seja, mas sim assinalar um diagnóstico que nos impele a uma ação decidida e obstinada para inverter este quadro triste e inaceitável" SADER, 1988, p. 184-185, grifos do autor). 
diano das classes populares. Mas é engano pensar que elas são engessadas, pois são mescladas entre si e adaptadas a cada situação. São expressas a partir das falas dos novos sujeitos, que também modificam as próprias matrizes que os alimentaram. Dessa maneira, os movimentos sociais desse período possibilitaram aos moradores de ocupações uma experiência políticas, uma espécie de "política reinventada":

Ao observarmos as práticas desses movimentos, nós nos damos conta de que eles efetuaram uma espécie de alargamento do espaço da política. Rechaçando a política tradicionalmente instituída e politizando questões do cotidiano dos lugares de rabalho e de moradia, eles "inventaram" novas formas de fazer política (SADER, 1988, p. 20, grifo meu).

$\mathrm{Na}$ linguagem da igreja fala-se em conscientização, enquanto que na esquerda em reflexão crítica e no sindicalismo em socialização do saber (CHAUI, 1988). Portanto, os movimentos sociais passam a fazer política de uma outra maneira e em outros lugares, e a importância desses novos atores é justamente contribuir na construção de um novo tipo de conhecimento, com aderência popular, que ao ser incorporado pelo povo era ampliado e redefinido pela própria prática cotidiana. Para Doimo (1995), nesse período a ideia de "povo como sujeito" estava amparada e presente nos discursos dos atores sociais importantes nesse contexto, a autora cita:

a Igreja Católica, especialmente os seus setores progressistas, o ecumenismo, particularmente aqueles de perfil secular, ligado à ética do compromisso social; segmentos da intelectualidade acadêmica, principalmente os que fundaram centros independentes de pesquisa em resposta ao expurgo das universidades impetrado pelo regime militar: e agrupamentos de esquerda, então dilacerados pela ditadura e tão logo de e esquerda en tăo dilacerados pela ditadura e tăo logo dera (DOIMO, 1995, p. 74-76, grifo meu).

Portanto, emergidos das periferias para a cena pública e respaldado pelas matrizes discursivas, os novos sujeitos começaram a reivindicar direitos sociais, pois entendiam que se constituíam como sujeitos de direito. É importante pontuar que, para além das CEBs, existiram outros movimentos que agrupavam membros a partir de situações específicas. Singe e Brant (1980) fazem um importante registro das experiências daquele período. Os autores falam das associações de bairro, que assim como as CEBs, partiam das condições de vida no meio urbano; do movimento feminista e do movimento negro, a partir do estigma e das discriminações de gênero e raça, e, ainda, dos partidos políticos da época que partiam das relações de poder que envolviam as classes populares e o conjunto da sociedade. ${ }^{80}$

As periferias, portanto, representavam os espaços de onde emergia a renovação política. Valladares (2005) mostra como essa mudança de perspectiva de representar tais espaços não mais como problema mas sim como solução em grande parte se deu pela valorização do "saber fazer popular", da participação dos moradores desses territórios, “da voz do povo", e cita a importância da Igreja Católica. Segundo a autora:

A Igreja contribuiu fortemente para essa valorização na América Latina - lembremos que os anos 1960 foram os anos das comunidades eclesiais de base, do Concílio Vaticano II, da "opção pelos pobres", e essa perspectiva se difundiu entre os jovens profissionais que participavam das pastorais populares como "assessores permanentes e de acompanhamento", durante os anos 1960 e 1970 (VALLADARES, 2005, p. 133-134)

Com o fim da Ditadura Militar (1985), esse período é marcado por um campo democrático participativo potente, com avanços na conquista de direitos, expressos na Constituição (1988). A nova Constituição passa a reconhecer direitos políticos, sociais e civis, estabelece a criminalização do racismo, reconhece os indígenas como cidadãos brasileiros, cria Sistema Único de Saúde e o Sistema Único de Assistência Social. E são aprovados o Estatuto da Criança e do Adolescente e novos mecanismos de democracia participativa.

Vale destaque também a criação do Fórum Nacional de Reforma Urbana (FNRU) em 1987, fruto de uma luta que reuniu

80 Depois da grande repercussão que teve o livro "São Paulo, 1975: crescimento e pobreza" (CAMARGO et al., 1975), parte dos autores continuaram suas pesquisas sobre a forma como o povo paulistano enfrentava seus problemas. Dessas pesquisas resultou o livro "São Paulo: o povo em movimento" (SINGER; BRANT, 1980), que traz um olhar inovador para época por procurar caracterizar os movimentos sociais a partir do ponto de vista das pessoas que os constituiam, já que "entrevistas com líderes e participantes dos movimentos, exame de documentos e publicações fornecidos por eles, participação dos pesquisadores em reuniões e manifestações permitiram tomar como ponto de partida a visão que os movimentos sociais têm de si proprios e dos problemas que enfrentam" (SINGER; BRANT, 1980, p. 12). Com esse livro, os autores tinham como objetivo contribuir para a organização e expressão dos movimentos sociais. Esse livro inspirou o titulo desta dissertação. 
movimentos sociais, parte progressista da Igreja Católica, lideranças de movimentos sociais, entidades sindicais, profissionais, acadêmicos e servidores públicos, que tinha como intuito propor uma agenda unificada para as cidades e superar as reivindicações pontuais e específicas (MARICATO,

2014). Como resultado das mobilizações em torno do Fórum é possível destacar a inserção dos artigos 182 e 183 na Constituição Federal, que estabelecem a função social da cidade e da propriedade. ${ }^{81}$ Sobre esse processo, Maricato faz a seguinte reflexão:

O FNRU foi um dos responsáveis pela inserção na Constituição de 1988 de algumas conquistas relacionadas à ampliação do direito à cidade. No entanto, ele cometeu o equívoco de centrar o eixo de sua atuação em propostas formais legislativas, como se a principal causa da exclusão social urbana decorresse da ausência de novas leis ou novos instrumentos urbanísticos para controlar o mercado, quando grande parte da população está e continuaria fora do mercado ou sem outras alternativas legais e modernas (isto é, sem segurança e sem um padrão mínimo de qualidade (MARICATO, 2013a, p. 143).

\subsection{ANOS 1990-2000: INFLEXÕES E COEXISTÊNCIA DE MUNDOS}

Nos anos 1990, permanece o padrão de crescimento do Município de São Paulo, que desde os anos 40 se deu pela expansão da mancha urbana para a periferia. Nessa década a periferização foi ainda mais acentuada, pois segundo Pasternak-Taschner e Bógus (2001, p. 35): "entre 1991 e 1996 todos os anéis, com exceção do periférico, apresentaram taxas negativas. Assim, a totalidade do crescimento municipal, de quase 200 mil pessoas entre 1991 e 1996, foi devida ao aumento po-

81 Vale destaque também a eleição petista de Luiza Erundina à Prefeitura de São Paulo em 1988. Esta é uma gestão de referência até hoje por instituir programas como o FUNAPs Comunitária - que incentivou a construção de moradias partir de mutirões autogeridos como principal produção habitacional públicacomo também pela qualidade da equipe técnica, com secretários como Paulo Freire, Erminia Maricato, Paul Singer, e Marilena Chaul. Essa gestão é reconhecida pela inversão de prioridades, bem como democratização e transparência. Maricato (2O19), em conversa concedida a pesquisa, destacou essa gestão de Erundina (1989-1992), bem como a de Marła Suplicy (2001-2004) também em São Paulo, Olivio Dutra (1989-1992) em Porto Alegre e João Paulo (20012009) em Recife. Para ela, essas foram prefeituras referenciais, democráticas e populares, periodo que chama de "ciclo virtuoso do poder local. pulacional na periferia”. Em termos percentuais esse incremento é significativo, já que nos anos 60 o anel periférico foi responsável por $43 \%$ do incremento populacional, já em 70 passa a ser 55\% entre 1980 e 1991 significa 94\% e entre 1991 e 96 por 262\% (PASTERNAK-TASCHNER; BÓGUS, 2001) (Tabela 3.1).

TABELA 3.1 - TAXA DE CRESCIMENTO POPULACIONAL, SEGUNDO ANEL, NO MUNNCIPIO DE SÃO PAULO

\begin{tabular}{lcccc}
\hline & $1960-70$ & $1970-80$ & $1980-91$ & $1991-96$ \\
\hline Central & 0,72 & 2,23 & $-0,91$ & $-2,79$ \\
Interior & 0,08 & 1,26 & $-1,4$ & $-2,43$ \\
Intermediário & 2,79 & 1,28 & $-1,14$ & $-2,43$ \\
Exterior & 5,52 & 3,13 & 0,86 & $-0,51$ \\
Periférico & 12,90 & 7,42 & 3,09 & 2,48 \\
TOTAL & 4,79 & 3,67 & 1,16 & 0,40 \\
\hline FONTE: Fundacăo IBGE. Censos Demogrático de 1960, 1970, 1980, 1991 e Contagem
\end{tabular}

Os dados revelam que nesse período houve uma diminuição relativa da concentração populacional nas áreas centrais e regiões do seu entorno, enquanto que ocorre uma verdadeira explosão demográfica em seus pontos mais distantes, nas chamadas "zonas de fronteiras". ${ }^{82}$ Essas áreas se caracterizam por um combinado de questão social com problemas ambientais (TELLES, 2006), já que a expansão ocorre nas franjas periféricas em áreas de preservação dos mananciais ao sul (represa de Guarapiranga) e ao norte (serra da Cantareira). Segundo Maricato (2013), não é em qualquer localização que as ocupações de terras urbanas são "toleradas", uma vez que o critério definidor é o do mercado ou da localização. São áreas desvalorizadas ou inviáveis que "sobram" para os empobrecidos, ocasionando em muitos casos a deterioração ambiental. A questão é que muitas vezes a "culpa" recai em quem ocupa, quando na verdade a predação ambiental é promovida por essa dinâmica de exclusão social, econômica e territorial. Maricato (2013) descreve esse processo como sendo a expulsão dos empobrecidos para a periferia da periferia:

82 Segundo o Censo de 2010, enquanto as áreas centrais decresceram entre 1991 e 2000, entre 2000 e 2010 voltaram a crescer substancialmente (a mais de 2,5\%), ver Marques e Requena (2013). 
A disputa por terras entre o capital imobiliário e a força de trabalho na semiperiferia levou a fronteira da expansão urbana para ainda mais longe: os pobres foram expulsos para a periferia da perife Novas áreas de proteção ambiental, como área do

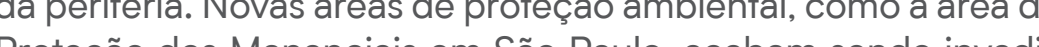
Proteçâo dos Mananciais em São Paulo, acabam sendo invadidas pelos sem alternativas, pois a politica habitacional está longe do núcleo central do déficit (MARICATO, 2013b, p. 24).

Nesse sentido, nos anos 90, a segregação urbana continua operante, no entanto a dinâmica já não é a mesma. Os deslocamentos socioespaciais já não são mais resultado dos fluxos migratórios, pois estes diminuíram durante a década de 1980 e apresentaram saldos negativos nos anos 1990, o que Grafmeyer (1995) chamou de uma transição entre "trajetórias de inserção" para uma predominância de "trajetórias de exclusão". Nos anos 90, esses deslocamentos são resultado de um "cruzamento entre as forças operantes no mercado de terras e especulação imobiliária, a fragilização dos vínculos de trabaIho e encolhimento de alternativas de emprego, e outros tantos que vêm de uma história já antiga de ausência ou precariedade de políticas habitacionais" (TELLES, 2006, p. 59).

Nos anos 90, a reestruturação produtiva no mundo do trabalho se deu pela inserção do ideário neoliberal, em contraposição à políticas sociais e programas de distribuição de renda. Foi uma década de crescente desindustrialização e redução do trabalho formal em regime celetista (Consolidação das Leis do Trabalho CLT), aumento do desemprego e do trabalho precarizado, resultando no aumento das desigualdades e na explosão da informalidade. Maricato (2019), destaca que nesse período as periferias deixam de ser operárias e passam a ser majoritariamente "informal”. Telles (2006) sintetiza as inflexões ocorridas nesse período:

sso que se convencionou chamar de desregulação neoliberal em tempos de globalização, financeirização da economia e revolução tecnológica fez por desestabilizar as referências - parâmetros pelos quis pensar a cidade (e o pais) e suas questões, ao mesmo tempo em que as realidades urbanas se questificam ritmo aco modificam emritmo acelerado. Se as conexōes que antes ariculavam trabalho, cidade e politica foram desfeitas, é como se, agora, cada um desses termos passasse a polarizar outros feixes de questões e compor outras relações que escapam do espaço conceitual no qual o debate dos anos 80 se processava. E desse ponto de clivagem que partimos. Se antes a questão urbana era definida sob a perspectiva (e promessa) do progresso, da mudança social e do desenvolvimento (anos 60/70)

versalização dos direitos (anos 80 ), agora os horizontes estão mais encolhidos, o debate é em grande parte conjugado no presente imediato das urgências do momento, os problemas urbanos tendem a deslizar e se confundir com a gestão urbana (TELLES, 2006, p. 14, grifo meu).

Periferias caracterizadas nas décadas anteriores, pela migração de famílias nordestinas, católicas, que trouxeram o sonho de melhoria de vida via trabalho formal e da conquista da casa própria pela autoconstrução, fortalecidas pelos movimentos sociais das décadas anteriores e na expectativa da universalização de direitos, na década 90 passam por diversas inflexões devido ao forte desemprego e a não universalização dos direitos, o que desencadeia processos como a expansão das igrejas neopentecostais, do mundo do crime e do militarismo. Para essas famílias não mais tanta certeza do futuro, já que antes existia um certo modelo organizativo familiar, social e político centrado no projeto operário e na garantia de direitos, mas a partir desse contexto o "projeto de família operária" entra em crise e muitas vezes em uma mesma família passa a coexistir trajetórias de vida muito distintas, individualizadas e heterogêneas. ${ }^{83}$

Filhos de migrantes operários já não são mais nem migrantes e nem operários. Nascidos na capital paulista e sem nunca terem pisado numa fábrica percorrem trajetórias muito distintas daquelas percorridas por suas famílias de origem (FELTRAN, 2011). Trajetórias distintas inclusive para membros de uma mesma família, enquanto alguns tiveram acesso à universidade (em geral privada) e carteira assinada no regime CLT, outros estavam inseridos em mercados informais e ilícitos.

Década marcada também pela inserção dos movimentos sociais, provenientes das periferias, na política institucional. Inserção que fez com que a renovação política vivida na década

83 Sobre o "projeto de família operária", segundo Feltran (2011, p. 96): "traa-se de um arranjo familiar estruturado em torno de um projeto de ascensão social pelo trabalho, com a religiosidade popular cristã (católica e, por vezes, protestante) imprimindo o código moral de coesão entre os membros. Os papéis de cada um na familia são bem estabelecidos, delineados, acima de fudo, pelo gênero e pelo respeito aos mais velhos. Os filhos devem estudar e a familia se desdobra para garantir o estudo, que proporciona um futuro melhor para eles. 
anterior se fragilizasse. ${ }^{84}$ Feltran (2003) explica que a redemocratização brasileira abriu espaço para essa inserção e os movimentos sociais acostumados a lutar contra o Estado passaram atuar nos "novos espaços de participação", ou seja, após décadas como atores de resistência, passaram a ser possíveis "parceiros" do Estado. Alguns autores interpretaram esse período como sendo a "morte" dos movimentos sociais (CARVALHO; LANIADO, 1989), enquanto que outros consideraram essa mudança como "ponto de inflexão" na maneira de atuar dos movimentos, atuação mais voltada à negociação com o Estado e menos na mobilização de base popular (DOIMO, 1995).

Enquanto se discutia a "consolidação democrática" do Brasil e a integração social via políticas públicas, com a expectativa da "extensão da cidadania", a realidade das periferias era outra: não houve a tão esperada consolidação de direitos, mas sim a intensificação da violência e da privação, no que Feltran (2O2Oa), seguindo Mano Brown, caracterizou de verdadeiro "Holocausto urbano".

Em Holocausto urbano, ${ }^{85}$ Mano Brown canta: "então quando o dia escurece, só quem é de lá sabe o que acontece”, demonstrando o cotidiano das periferias marcado pelo aumento da taxa de homicídios e pela guerra entre crime e polícia. "Menores carentes se tornam delinquentes, e ninguém nada faz pelo futuro dessa gente": o mundo do crime se fortalecendo com implementação de mercados transnacionais de drogas, que tem como "mão de obra" a massa disponivel de desempregados, subempregados e ilicitamente empregados. "E se você der o azar de apenas ser parecido": denunciando a violência e o racismo, no qual determinados corpos são marcados para morrer - a depen-

84 Relatos da Luiza Erundina explicam bem esse momento de transição: "voce tinha uma sociedade fortemente mobilizada, politizada, vindo de um processo de vimento socialtadura que fez a luta crescer e avançar, dar saltos mesmo. O modo campo progressista etc. Então veio essa conquista [a Constituicão Federal fruto desse momento. Qund se institucionalizaram assas conquistas [ ] houre uma certa desmobilizaça da sociedade, que é naturat. [.] Aquelas lideranças que antes estavam na organização popular passeram a estar nos espacos insttucionais [ ] Então a luta, de uma certa forma, passou a ter uma expressão mais institucional porque jé não era o quadro de transicão de um resime de ditadura para um regime democrático. Então há um certo esvaziemento da luta reivindicativa da luta social A' a luta vai para os partidos polticos, para os setores organizados da sociedade, ONGs, entidades" (FELTRAN, 2003, p. 39).

85 Trechos extraidos do album Holocausto Urbano, do grupo de rap paulistano Racionais MC's, lançado em 1990. der da raça, classe e gênero - pois "o sistema é racista cruel”. As periferias passam a ser figuradas no mundo público como lugar de atraso, pobreza e violência, repleto de estigmas sociais, onde a "democracia” não tinha chegado (FELTRAN, 2O2Oa). ${ }^{86}$

Valladares (2005) mostra como essa representação social passa a ser amplamente discutida no meio acadêmico e público. Se durante os anos 1970 e 1980 a participação popular, a partir da atuação dos movimentos sociais, foi prioridade na agenda dos pesquisadores, nos anos 1990 a violência urbana e a criminalidade passaram a fazer parte dessas agendas ${ }^{87}$. A exclusão passa a ser chave de leitura para esses territórios nos trabalhos acadêmicos e na imprensa em geral. Zaluar (1999) expõe que nesse período os empobrecidos foram figurados no meio acadêmico como protagonistas da violência e suas vítimas mais frequentes. Já o trabaIho de Vianna (1997) demonstra o tema da violência amplamente presente nos estudos dos pesquisadores brasileiros, onde as favelas e periferias são identificadas como os territórios do tráfico de drogas. Ventura, em "Cidade partida" (1994), elabora a imagem da favela carioca Vigário Geral como o lugar que "a república não chegou", descrevendo como um apartheid socioespacial que separa favelas do resto da cidade, ideia que segundo Valladares:

[...] difundiu-se rapidamente no pensamento sociológico brasileiro, apoiado no argumento da dualidade e da polarização favela/ asfalto: apesar do retorno ao regime democrático, o afastamento entre ricos e pobres não deixou de aumentar, o esforço dos ricos para preservar seus privilégios passou a ser cada vez mais vigoroso o abandono social pelo Estado mais manifesto. As categorias populares, abandonadas à sua sorte e excluídas de qualquer projeto de transformação social, assistiram ao espaço urbano ser privatizado e à segreģac̃o atingir uma intensidade ate então desconhecida (VALLADARES, 2005, p. 143, grifo meu). 86 Mundo público aqui é designado como "espaço de visibilidade, circula-
ção e confronto de discursos, em que se disputa e exerce poder. [.... Os debates do mundo público têm relação direta com a politica porque são fundados por ela, embora esta também se construa fora dele, pois em sociedades muito hierárquicas e desiguais, estão representados no público apenas uma parte dos atores e dos interesses presentes no mundo social" (FELTRAN, 2011, p. 13).

87 A midia teve papel importante para difusão dessa representação social, de acordo com Valladares (2005, p. 142): "em 1984 a Rede Globo de Televisão, em parceria com o IBOPE (Instituto Brasileiro de Opinião Pública e Estatística) distribuiu questionários em toda a região metropolitana do Rio para a campanha "O Rio contra o Crime", procedimento que já demonstrava a imoortância desse fenômeno para a população. A partir dai imprensa e meios de comunicação em geral vêm divulgando insistentemente informações e imagens sobre atos de violencia individuais e coletivos". 
3.2.1 NOVAS MATRIZES DISCURSIVAS: QUANDO OS MAIS NOVOS PERSONAGENS ENTRARAM EM CENA

A expectativa da "extensão da democracia", ou seja, que após a redemocratização o regime democrático se estenderia, se mostrou frustrada para quem vivia nas periferias paulistanas. Acreditavam que era só questão de tempo, mas não foi. Assim, as dificuldades do dia-a-dia passaram a ser amparadas por diferentes regimes normativos, presentes no chão dessas realidades:

[...] no cotidiano das periferias, as mães dos filhos assassinados pelas guerras do mundo do crime tiveram suporte das igrejas evangélicas, não das políticas públicas. Os trabalhadores e estudantes que voltavam para casa à noite também não contarum com politicas públicas casa à noite tamben não contaram com politicas públicas de segurança. Contavam ora com a segurança dos traficantes locais, ora com policiais dos próprios bairros, que faziam bicos como segurança privada (FELTRAN 2020a, s/p.).

A efervescência dos anos anteriores foi pouco a pouco sendo reduzida com o abandono das periferias por parte do poder público, enquanto que seus moradores tiveram que lidar com as dificuldades cotidianas. Para Maricato (2019), nesse período houve o afastamento das periferias das forças progressistas presentes nas décadas anteriores, sendo que as lacunas deixadas foram ocupadas por outras forças, boa parte delas conservadoras. Ou seja, os sujeitos periféricos passam a ter como referência e serem amparados por "novos atores sociais". Com isso, novas matrizes discursivas passam a disputar o cotidiano das periferias. Feltran (2O2Oa) ressignifica as matrizes discursivas, que segundo ele passam a ser:

i) o militarismo das Forças Armadas e das polícias militares, que agem como seu braço armado; ii) o anti-intelectualismo evangélico, que há muito é majoritário nas periferias e mobiliz moralmente as massas em direção contrária à da racionalidade moderna, dos argumentos, e a orienta na direção do totalitarismo; iii) o empreendedorismo monetarista de parcelas do mundo popular que consideram que você é o que você tem, simplificando bastante a teoria dos capitais (FELTRAN, 2020a, s/p.)

Assim, a partir desse período nas periferias, três redes de influência se constituem como organizadores das vidas e das relações sociais: a estatal, o religioso e o crime organizado (BERALDO, 2O2O; FELTRAN, 2014a, 2018, 2020a). São como mundos totalizantes, que tentam influenciar por completo a vida de quem participa e se apresentam como independentes, mas que, na realidade, coexistem com seus integrantes podendo viver parcialmente em cada um desses mundos. Esses mundos:

Espraiam um "dever ser", um ideal de conduta esperado para a vida de todos. O Estado espera que, nas periferias todos sejam trabalhadores disciplinados o cumpram suas leis, por isso jam trabalo combate os fora da lei. O mundo do crimespera que, nas periferias, todos estejam em paz entre si, mas em guerra contra o sistema estatal. O mundo religioso espera que todos aceitem Jesus e atuem segundo seus mandamentos, mas faz alianças tácitas com os outros poderes, instrumentalizando-os sempre que possivel para crescer (FELTRAN, 2018, p. 100-101).

Por espalhar normas ideais de conduta são entendidos como regimes normativos, sendo que fazer parte da igreja, das instituições do estado e/ou do mundo do crime é pertencer a uma lógica específica de ver a vida (FELTRAN, 2O2Ob). Os regimes desempenham importante papel na organização da vida comunitária, na formação de redes de solidariedade e de sociabilidade, participando dos processos de subjetivação do mundo, de identificação e de sentido de existência dos sujeitos.

I. "Paz entre irmãos”: expansão do mundo do crime e guerra como rotina

Como visto, ao longo da década de 90 as periferias paulistanas tiveram significativas alterações. Após décadas de mobilização e reivindicação de direitos e aprovada a Constituição Federal em 1988, a expectativa para a década era de integração social dos empobrecidos. Mas essa expectativa foi frustrada para quem morava nessas periferias, pois a realidade era muito aquém da desejada, sendo que seus moradores tiveram que lidar com as dificuldades cotidianas a partir dos seus próprios meios.

Moradores com menor qualificação e sem qualquer apoio estatal ocuparam posições menos promissoras no mercado de trabalho, muitas vezes sem carteira assinada, sem qualquer segurança ou estabilidade, em cargos de menor remuneração e reconhecimento social. Se outrora havia a esperança de que o trabalho assalariado possibilitaria o projeto de ascensão social, passaram a entender que o caminho de melhoria de vida via trabalho formal estava bloqueado. Com a crise econômica e a reestruturação produtiva da virada para os anos 1990, muitos tiveram que recorrer ao mercado informal (em expansão nesse período) para enfrentar o desemprego. Os mercados informais, 
liminares entre o considerado legal e ilegal, como por exemplo o mundo do crime, ${ }^{88}$ foram possibilidades que se apresentaram aos menos estruturados (FELTRAN, 2018).

O mundo do crime passa a ser possibilidade para obtenção de renda, mas também de identificação dos sujeitos periféricos com o mundo, a partir do qual constroem suas subjetividades. Mundo que tem uma ideologia própria, "ideologia do crime", cuja narrativa demonstra que não basta resistir ("resistência" palavra de ordem das décadas anteriores), mas "bater de frente", "ir contra" o sistema, de reagir agressivamente contra as opressões cotidianas. A legitimidade do mundo criminal sobrevém dessa narrativa, à medida que passa a fazer sentido e ajuda a compreender a condição de vida de tantos, sobretudo dos negros e pardos (em geral nordestinos, e de seus filhos nascidos já na capital, não mais migrantes). É a parcela da sociedade mais empobrecida entre os mais empobrecidos e o mundo do crime está de portas abertas para recebê-los (mesmo que não seja uma "porta" socialmente aceita), enquanto tantas outras portas se fecharam. Nesse sentido, o "mundo do crime se torna um caminho lateral às tentativas de integração social" (FELTRAN, 2018, p. 137)

Narrativa que tem forte aderência para aqueles que estão sobretudo imbuídos pela revolta. Revolta por um sistema que não somente oprime e exclui, mas ao excluir fere o sentimento de pertencimento à sociedade (FRANCISCO, 2013). Revolta pela frustração da promessa de integração social, já que a democracia eleitoral mostrou-se insuficiente para o estabelecimento de uma cidadania democrática (CALDEIRA; HOLSTON, 1999). Pelo contrário, engendrou uma democracia violenta (ARIAS, 2006) e uma cidadania racializada (ALVES, 2014).

Assim, para o morador de periferia a violência passa a fazer parte de sua vida cotidiana, seja pela ação contraditória do Estado, pela disputa entre facções e, ainda, pela guerra entre elas contra a polícia. Violência em um "mundo sob cerco", nos termos de Machado da Silva (2008), pois experienciam a violência do "mundo do crime", como também a violência política

88 "Mundo do crime" é termo comumente usado e se refere a "conjunto de códigos e sociabilidades estabelecidas, prioritariamente no ambito loca. em torno dos negócios ilicitos do narcotrático, dos roubos e furtos" (FELTRAN. 2008, p. 93) e a marginalização social (BERALDO, 2020). As altas taxas de homicídio demonstram a explosão da violência tão falada nos anos 90 , que faz com que as favelas e periferias sejam figuradas como territórios da desordem e do crime.

A crescente taxa de homicídio na década de 90 pode ser explicada pela maneira como "justiça" e "segurança" eram praticadas até então, entendidas como "responsabilidade" dos próprios moradores que as realizavam através dos chamados "justiceiros", ocasionando uma reação em cadeia de vinganças. Os "bandidos" eram tidos como figuras diametralmente opostas às comunidades.

A partir dos anos 2000, com a expansão das facções criminosas, essa concepção se altera significativamente. Se antes os moradores faziam justiça com as "próprias mãos" e ajudavam os policiais a controlar os territórios, a partir desse período passaram a contar com os membros das facções para ajudar nesse controle. Isso explica a significativa diminuição da taxa de homicídio entre 2001 e 2011 no estado de São Paulo (Grafico 3.2). Diminuição que não pode ser atribuída a políticas públicas bem sucedidas, mas a auto-regulação de um "mundo do crime" cada vez mais poderoso e inserido no cotidiano das periferias, sobretudo através do surgimento e fortalecimento do Primeiro Comando da Capital (PCC). Feltran explica esse período de transição da era dos justiceiros para a era PCC:

É exatamente por bloquear a cadeia de vinganças privadas que $\circ$ dispositivo dos "debates" demonstra incidir mais radicalmente na queda das taxas de homicídio em São Paulo a partir da emergenqua do PCC nas quebradas do estado (FELTRAN, 2018, p. 228).

GRÁFICO 3.2 - TAXA DE MORTALIDADE POR HOMICIDIO

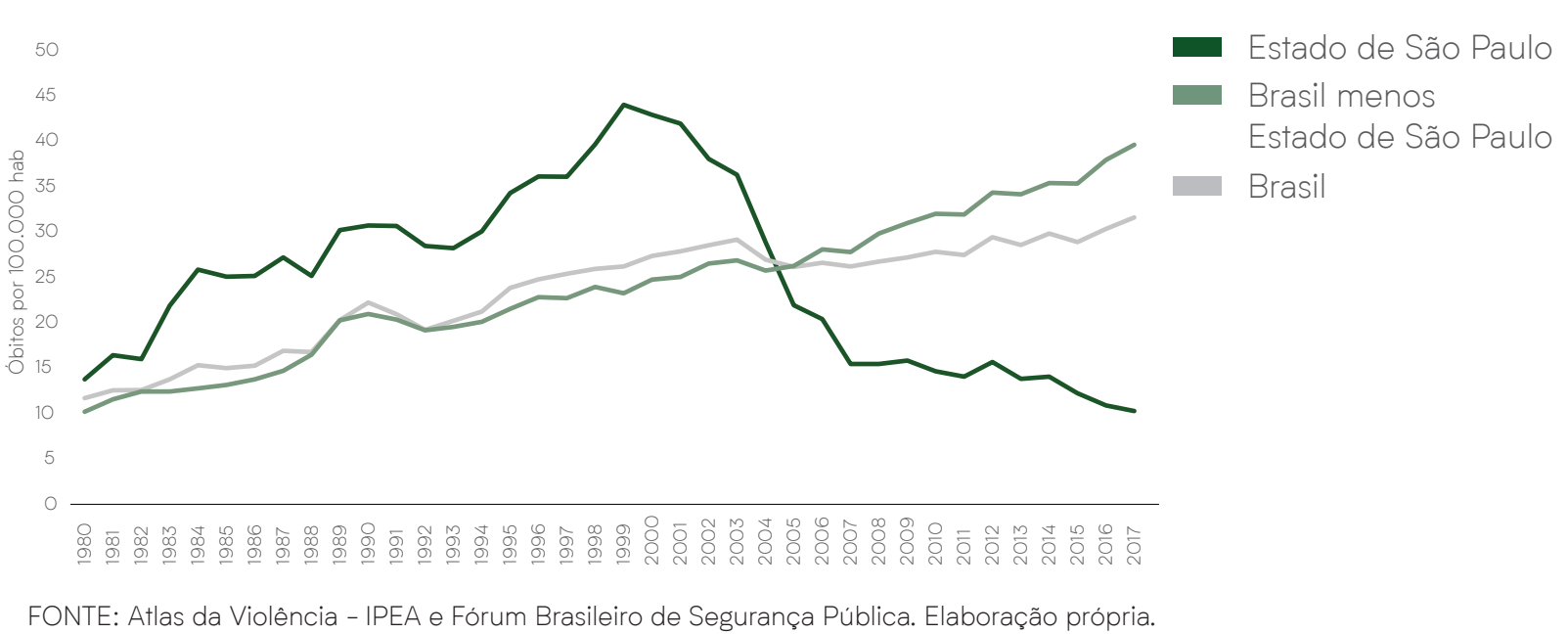


O surgimento do PCC, em 1993, remonta o período do Holocausto urbano, em que, como dito, o mundo do crime estava se fortalecendo com mercados transnacionais e também de intensa guerra entre crime e polícia. Guerra que resultou (e ainda resulta) em políticas de segurança pública equivocadas, como, por exemplo, a reforma penal dos anos 90 que quadruplicou a população carcerária paulista, jogando "jovens trabalhadores do tráfico" nas cadeias. Como veremos, é um processo de retroalimentação, um verdadeiro "enxugar gelo".

O aumento intenso da população carcerária ${ }^{89}$ e a interiorização dos presídios ${ }^{90}$ com a descentralização do sistema carcerário $e$ massacres nos presídios foram imprescindiveis para criação consolidação do PCC, pois sua hegemonia foi construída primeiramente dentro das prisões (chamadas de "faculdades") com o objetivo de instaurar "paz entre ladrões e guerra contra o sistema”. ${ }^{11}$ Paz entre os ladrões com objetivo de buscar unidade, ${ }^{92}$ já que até aquele momento o que predominava era a "lei do mais forte" (dentro e fora das prisões). Guerra contra o sistema tanto se referindo às opressões do sistema carcerá-

89 Nos anos 2000 a população carcerária era quatro vezes maior do que na década de 1990. Nas palavras de Feltran (2014 p. 504): "Nunca se apostou tanto no encarceramento daqueles que se classificam como sendo seus artifices: homens jovens e pretos, pardos ou favelados, que levaram a sério a incitação orgiástica por consumo de carros, motos e mulheres, dinheiro fácil, cerveja e "vida loka". Tínhamos 45 mil presos no estado de São Paulo em 1996: hoje, eles são mais de 200 mil. A chamada "populacão carcerária" segue crescendo, com metas precisas, e sua média etária ultrapassa pouco os 20 anos de idade."

90 O Massacre do Carandiru (1992) é um divisor de águas para a área de segurança pública em São Paulo, pois marca tanto a origem do Primeiro Comando da Capital como tambem da polifica de expansáo radical das unidades prisionais em São Paulo. Para D'Andrea (2013, p. 54), essa ação extremamente violenta "evidenciou como nenhum outro a violencia estatal contra populaçōes marginalizadas". Ja Feltran (2018, p. 176) coloca que "os reflexos politicos dessas criaturas seriam sentidos apenas multo mais tarde, mas emolduram hoje o problema da segurança no estado, no pais e na America Latina. A expansão do PCC dentro das prisões de São Paulo entre 1993 e 200 enquanto a facção ainda não era tão conhecida no cotidiano das periferias, deveu-se muito a essas duas mudanças."

91 Diversos autores trabalharam sobre esse tema, entre eles: ADORNO; SALLA 2007: AMORIM 2004: BERALDO 2020: BDNDI 2016: FELTRAN 2018 : 2020 MANSO; NUNES DIAZ, 2017; MARQUES, 2013; SINHORETTO, 2014.

92 Em 1993 o PCC anunciou o lema da facção a princípio como "Liberdade, Justiça e Paz", posteriormente, apos conflitos e uma revolução interna do PCC, foram adicionados: "Igualdade e Uniâo". rio ${ }^{93}$, como também à dominação do Estado e ainda do rico sobre o empobrecido (FELTRAN, 2018).

Enquanto que para os membros da facção se falava em guerra contra o sistema, o discurso estatal e midiático era guerra contra o crime, com a ideia de reprimir ainda mais o crime e acabar com a impunidade, o que na prática é uma guerra contra os “criminosos". Nas palavras de Feltran (2018, p. 186): “A questão não era encarcerar melhor, e sim encarcerar mais. Não tratar os bandidos como titulares de direitos, mas evitar que continuassem impunes".

Políticas equivocadas e que retroalimentam a acumulação social da violência (MISSE, 2009): quanto mais se mata e prende, aumenta polícia, aumenta o crime, intensificando cada vez mais o conflito sem qualquer alteração na base social. Esse modelo, praticado há praticamente 30 anos, mostra-se equivocado pois exacerba o controle social sem resultar em segurança pública. Enquanto acreditava-se que estavam acabando com a facção, o PCC se fortalecia e capilarizava, dentro e fora das prisões. Feltran (2015), no Quadro 3.1, traz uma síntese das políticas estatais e as do "crime".

A primeira grande aparição pública que demonstrou a força da facção até então desconhecida foi a Megarebelião de 2001, na qual houve simultaneamente revolta em 29 presídios de São Paulo. A resposta por parte do estado a esse evento foi a criação do Regime Disciplinar Diferenciado (RDD), que teve como objetivo isolar as lideranças do PCC. Mas, como a facção se organiza em rede, prender as lideranças e fazê-las circular pelo país só agravou ainda mais a situação. As Revoltas de 2006 se constituíram como o segundo momento em que foi possível conhecer as novas (e enormes) dimensões do Comando. Foram realizados ałaques simultâneos, em várias cidades do estado de São Paulo, a agentes do governo e rebeliões em mais de oitenta presídios. Foi amplamente divulgado na mídia como "ataques do PCC" e fortemente reprimidos pela força policial, em

93 Eram recorrente as denúncias de tortura por parte dos presos, por exemplo. Com a instauração do PCC algumas medidas são tomadas, como: negociação com a administração penitenciária, interdição do estrupro, oferta de justiça em qual caso de opressão ou desrespeito às regras básicas de convivio, proibição do uso do crack, entre outras. Medidas que afetam de forma direta as condições de vida nos presídios e assim legitimam a facção (FELTRAN, 2018). 
POLÍTICAS ESTATAIS

POLÍTICAS DO “CRIME”

199

\section{Massacre do Carandiru}

1993 Reforma, expansão e
interiorização dos presidios

Emergência do PCC- Paz,

$$
\begin{aligned}
& \text { Guerra à opressão - } \\
& \text { interdição ao estupro } \\
& \text { e homicidios injustos / }
\end{aligned}
$$
"Guerra ao sistema"

1994

Inicio do encarceramento Fortalecimento dos massivo

Tráfico de drogas equivalente a crime hediondo

"debates" como r

justiça

Paz entre os ladrões

Organização piramidal

Legitimação no sistema carcerário

2001

Depois da "Megarebelião" criação do RDD

“Megarebelião" Interdição do crack Sistemas de posições despersonalizadas em rede Expansão às periferias

"Ataques do PCC"

Regulação dos mercados criminais nas periferias congelamento de preços

Reinvidicação do

monopolio legítimo da força nas periferias Comando, que não operava somente dentro das prisões.

Das prisões o PCC expandiu-se para periferias, estabelecendo a ordem, que sempre foi uma das principais aspirações das comunidades. O PCC não inventa o certo, o justo ou a lei da favela, mas institucionaliza um tipo de justiça que já era praticada nesses territórios antes do seu surgimento, como por exemplo a repulsa e a morte aos estupradores. A facção, portanto, passa a ofertar justiça comunitária, já que a justiça estatal não funcionava. O Estado não garantia proteção, tanto que mesmo antes do PCC, quando existia uma injustiça, o morador em geral recorria a alguém ligado ao mundo do crime, por exemplo, o traficante local.

Uma comunidade é considerada PCC quando há hegemonia política do Comando no mundo do crime daquele território, que é basicamente a regulação econômica (por exemplo o preço da droga) e reivindicação do monopólio da força e da justiça. Mas isso não significa que há uma personificação do poder ou monopólio do mercado ilegal. Muito diferente do estereótipo "donos do morro no RJ", por exemplo, o PCC funciona a partir de uma chefia sem mando, descentralizada de maneira que os membros têm acesso apenas às informações necessárias à sua posição de responsabilidades, sem acesso às demais.

A facção é como uma sociedade secreta cuja organização é semelhante à maçonaria, metáfora elaborada por Feltran (2018) para entender o funcionamento do PCC, que se organiza a partir das chamadas "sintonias" ou "lojas", que por sua vez agem com autonomia. São células autônomas onde há po-

94 Houve muita informação desencontrada e criou-se uma sensação de suspensão de ordem, uma verdadeira guerra. Segundo Feltran (2018), havia um descompasso entre o que aparecia no debate público e o que aparecia na etnografia, inclusive com relatos de moradores que viram policiais escrevendo "PCC" em muros para forjar uma descoberta de cativeiros da facção. Os homicidios praticados por policiais tiveram altas taxas nas semanas e meses seguintes a esse evento, inclusive de maneira silenciosa e subnotificada. E os números publicados de mortos pela contra ofensiva policial foram entendidos como acréscimo à ordem urbana. Por esse motivo as familias das vitimas passaram a chamar esse evento como "Crimes de Maio" e tiveram que lidar com a violência que interferia de forma direta no cotidiano das periferias. Não temiam o PCC, o crime, mas que os policiais invadissem suas casas à procura dos "suspeitos". 
sições de poder, como os chamados "disciplina" ou "sintonia", que concentram autoridade, a qual não se refere à pessoa mas à própria posição, portanto a autoridade pertence à irmandade como um todo. As posições de prestígio e decisão são conquistadas a partir da trajetória da pessoa, da sua caminhada pessoal dentro do crime.

O domínio do PCC no território tem como objetivo progresso dos irmãos (sujeitos batizados no PCC), a partir da paz nos territórios, pois a guerra não é boa para a comunidade e muito menos para os negócios. Feltran explica a visão de progresso:

Como em toda fraternidade, no PCC há apoio mútuo entre os irmãos. Ninguém atravessa os negócios nem a honra do outro irmão, todos se ajudam e assim cada um prospera, garantindo o progresso da irmandade. Na visão dos seus integrantes, progivo da sociedade é o progresso dos irmãos. Cograntes, o quêtiva da sociedade e o progresso dos irmăos. Como consequência, o progresso de sua famila e comunidade de iguais. As do PCC o meio para esse progresso (FELTRAN, 2O18, p. 35).

A legitimidade do PCC não foi obtida somente pela coerção física, pois em geral a facção não domina com as forças armadas, nem pela exibição de armas. Isso significa que se preza pela reivindicação da justiça a partir da argumentação, das ideias, da mediação e, somente se necessário, o uso da força e da violência. Disso resultam os "debates" que são realizados no mundo do crime, nos quais todas as partes são escutadas, com uma ampla argumentação e a partir disso são dadas as deliberações. A decisão do que é certo e a reparação de danos são analisadas caso a caso, é sempre situacional, de maneira que tenha o mínimo uso de violência e evitando ao máximo o homicídio (apesar de ser previsto como possibilidade). Preza-se a aliança, o respeito e a paz entre os sujeitos periféricos (FELTRAN, 2O18).

Um debate serve para oferecer justiça a um morador que recorre ao PCC, considerado um governo local nas quebradas. Mas há outras formas de justiça a que se pode recorrer, como por exemplo o Estado (justiça legal) e as igrejas. Isso significa que o PCC não é um poder paralelo, como se costuma dizer mas que nas quebradas existem diferentes instâncias de justiça coexistentes, mais ou menos efetivas a depender da situação. Portanto, o crime é "uma entre outras instâncias de geração de renda, de acesso à justiça ou proteção, de ordenamento social, de apoio em caso de necessidade, de pertencimento e identificação" (FELTRAN, 2018, p. 171).

Dessa maneira, o PCC é um regime normativo que disputa legitimidade com atores que historicamente são legítimos, como a escola, a família, a religião, o trabalho, a Justiça, o Estado. A partir de relações tensas e intensas, esses atores começam a ter de lidar com a presença e a atratividade do mundo do crime entre os mais jovens e os mais empobrecidos, se colocando em oposição ao crime. Não somente a polícia trava a guerra contra o crime, mas também professores, assistentes sociais, psicólogos, educadores, militantes e pais de família (FELTRAN, 2018).

A expansão do mundo do crime nas periferias da cidade, na era PCC, se inscreve nessa disputa de legitimidade social, e não apenas no aumento das ações criminais. O que está em jogo nessa expansão é que o mundo do crime, antes visto por todos como o oposto diametral do trabalhador, pouco a pouco passa a concorrer como ator e instância de poder e ordenamento social nas periferias da cidade (FELTRAN, 2018, p. 163. grifo meu).

Portanto, ao fazer parte do cotidiano das periferias paulistanas, o mundo do crime passa a tensionar essas instâncias historicamente legítimas da sociabilidade. Passa a tensionar o mundo do trabalho, já que é também gerador de renda, muito atrativo para os jovens, e se apresenta como possibilidade real de ascensão social; a tensionar a religiosidade com disputa em diferentes tipos de moralidade e códigos de conduta; a tensionar o projeto de família, já que muitas vezes os pais não sabem lidar com os filhos envolvidos no crime; tensionar a justiça legal, que tem outras práticas para punição e reparação, sendo os "debates" organizados pelo PCC considerados mais efetivos e rápidos em muitos casos para resolução de conflito entre os moradores; e, ainda, a tensionar o Estado em seu cerne ao reivindicar para si o monopólio do uso da violência (FELTRAN, 2018).

Passa a tensionar todas essas instâncias porque gera efeito real sobre a vida do periférico, sobretudo do mais empobrecido, pois dissemina a ideia de que eles existem e podem ter poder, proporcionando sentimento de pertencimento e mostrando que o crime estava ali para fortalecê-los. É dessa identificação e sentido de existência que resulta a legitimidade do mundo do crime. Além disso, é importante ressaltar que, na maioria 
das vezes, a entrada no crime não é escolha, é o que resta para aqueles totalmente excluídos do sistema sem outras possibilidades, por exemplo a parcela da sociedade que com defasagem escolar muito forte não consegue um emprego, nem mesmo nos postos de trabalho no mundo popular onde muitas vezes é exigido ensino fundamental completo.

Trazer o surgimento do PCC dessa maneira parece demonstra que existe uma relação direta entre miséria e violência, quando não há (FELTRAN, 2018; MISSE, 1995). A miséria "sozinha" não causa violência, mas é explosiva quando somada a três fatores: desigualdade acentuada e explícita, ${ }^{95}$ mercado ilegal influente e não regulado, e encarceramento massivo, principalmente de adolescentes, a ponta desse mercado que ao serem presos se profissionalizam nas cadeias (FELTRAN, 2018).

A aderência ao crime, portanto, se dá pelo fato do Comando instaurar políticas baseadas na experiência vivida daqueles que não compreendem tamanha contradição social. Por isso, em muitos casos as políticas do crime tiveram mais efeito do que as políticas governamentais. As políticas do crime se afastam da proposta do projeto de nação trabalhadora, de futuro comum, de uma comunidade nacional integrada, muito defendida, por exemplo, pelos movimentos sociais. O crime promete pertencimento a uma guerra, emancipação, identificação e sentido de existência, mas não pertencimento a uma cidadania marcada por direitos (FELTRAN, 2018).

Assim, as políticas públicas se afastam de um universalismo e passam a defender um "país contra bandidos", pois "bandido não tem direito a ter direito", concepção muito diferente da elaborada no contexto das CEBs do morador de periferia que tinha "direito a ter direitos". As políticas públicas de segu-

95 O Papa Francisco reforça essa ideia quando escreve, no capítulo II da EG "não à desigualdade social que gera violência", nas suas palavras: "Hoje, em muitas partes, reclama-se maior segurança. Mas, enquanto não se eliminar a exclusão e a desigualdade dentro da sociedade e entre os vários povos será impossive desarraigar a violência. Acusam-se da violência os pobres e as populações mais pobres, mas, sem igualdade de oportunidades, as várias formas de agressão e de guerra encontrarão um terreno fértil que, mais cedo ou mais tarde, há-de provocar a explosão. Quando a sociedade - local, nacional ou mundial — abandona na periferia uma parte de si mesma, não há programas politicos, nem forças da ordem ou serviços secretos que possam garantiri indefinidamente a tranquilidade. Isto não acontece apenas porque a desigualdade social provoca a reaçao violenła de quantos são excluidos do sistema, mas porque o sistema social e económico é injusto na sua raiz" (FRANCISCO, 2013, p. 52. rança passam a ter o viés de prevenção de violência, que na prática é a prevenção do sujeito criminoso: o bandido deve ser reprimido ou ainda eliminado. Características como cor da pele, tipo de roupa, comportamento, idade são eleitas como supostamente indício de perigo e violência (BERALDO, 2020). Nos termos de Misse (2010), se trata de uma "incriminação preventiva", que reforça a diferenciação social e racismo estrutural presentes na sociedade brasileira. São corpos marcados para morrer nessa guerra. ${ }^{96} \mathrm{E}$ assim, de um lado a guerra contra bandidos e de outra a guerra contra o sistema fazem com que os diversos cotidianos das periferias paulistanas sejam marcados pela guerra como rotina.

\section{II. "Irmãos de fé": expansão do neopentecostalismo}

É importante refletir sobre as mudanças ocorridas no âmbito da religião, principalmente os desdobramentos da sua relação com a sociedade e a política ao longo das últimas décadas. Como visto, as Comunidades Eclesiais de Base possibilitaram um maior alcance territorial do catolicismo, mas a partir do final da década de 1980, com o enfraquecimento dos setores progressistas da Igreja Católica, esse enraizamento foi pouco a pouco sendo suprimido.

Entre os principais motivos é possível destacar a perseguição da Teologia da Libertação pelo próprio Vaticano e a divisão da

Săo Paulo possui o maior número de presos no pais e apresenta a maior taxa de encarceramento de negros em 2012, sendo 595 presos negros a cada grupo de 100 mil habitantes negros, enquanto que essa taxa cai para 288 no caso dos presos brancos. A taxa média do pais é de 292 a cada 100 mil habitantes negro. Também foi a UF que apresentou quedas expressivas e sistematicas, a partir de 1999, no número de homicídios, que em 2012 ficou reduzido em menos da metade do nivel de 2002. Os dados da letalidade policial revelam um racismo instifucional, nos termos de Sinhoretto (2014), 3 vez que foi constatado que a taxa de negros mortos pela polícia de SP 3 vezes a de brancos. 
Arquidiocese de São Paulo (1989), ${ }^{97}$ que criou novas dioceses autônomas com indicação de nomes conservadores da igreja para o cargo de "bispos".

Essa descentralização resultou na multiplicação de paróquias que cada vez mais passaram a priorizar a dimensão espiritual e ritualística da religião em detrimento da ação social e política.

Essas foram ações políticas conservadoras durante o papado de João Paulo II (1978-2005) para reduzir a influência da atuação da igreja progressista e apoiar o avanço dos segmentos Carismáticos na Igreja Católica, que além de ir contra o discurso politizado (presente nas CEBs, por exemplo), oferece uma alternativa à expansão da religião evangélica (ALMEIDA; MONTERO, 2001). Assim, enquanto ocorria o enfraquecimento da igreja progressista católica e seu distanciamento das periferias, o neopentecostalismo ${ }^{98}$ e sua moral evangélica de ver o mundo se expandia, alterando assim o perfil religioso de parte da sociedade brasileira.

97 Para Loro (1995), o desmembramento da Arquidiocese de São Paulo se deu por motivos politicos, apesar de ter sido justificado pelo Vaticano como sendo de ordem religiosa e financeira... Segundo o autor, o projeto de D. Paulo Arns para São Paulo tinha elementos que não eram aceitos pela Curia Romana. Com a divisáo, houve uma redução significativa dos territorios sob jurisdição de D. Paulo, sobretudo as areas mais empobrecidas e perifericas, justamente aquelas en que ele pronizava sua aluaça e faża um trabaho de evangelização e conscientizaçăo a partir da CEBs. Loro relata que: "nas

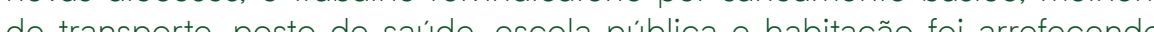

98 Nas duas primeiras décadas do século XX, missionários dos Estados Unidos e da Europa chegam à América Latina para fomentar a expansão de sua igrejas, principalmente entre as classes média e baixa. O momento marca emergência do Movimento Pentecostal, que faz uma releitura de correntes do protestantismo histórico: anticomunista, antiecumêmico e conservado politicamente, que rechaça reformas na estrutura social e adota uma concepção biblica literal. Os pentecostais consideram o esforço de conversão, inclusive de adeptos de correntes do protestantismo histórico, como uma de suas principais missões. Criada em 1911 por missionários suecos que viviam nos Estados Unidos, a Assembleia de Deus é considerada a primeira igreja pentecostal brasileira. Já na década de 1970 surgem as primeiras igrejas neopentecostais, com a adoção da Teologia da Prosperidade, que valoriza riqueza material: Igreja Evangélica Pentecostal Brasil para Cristo, Deus é Amor e lgreja Universal do Reino de Deus (QUEIROZ, 2019). O neopentecostalismo se diferencia por acreditar na palavra pos-biblica dos dons do Espirito Santo. incluindo glossolalia (falar em línguas), cura e realização de profecias.
Os dados dos censos demográficos demonstram um intenso trânsito religioso nas últimas décadas, ${ }^{99}$ como também a pluralidade de religiões. Um exemplo dessa multiplicação de alternativas religiosas é que enquanto no Censo de 1980 existiam apenas nove, em 2000 aumentou para 143 alternativas religiosas (ALMEIDA, 2004).

TABELA 3.2 - DECLARAÇÃO RELIGIOSA NA RMSP

\begin{tabular}{lccc}
\hline RELIGIÕES (EM \%) & 1991 & 2000 & 2010 \\
\hline Católicos & 78,92 & 67,05 & 56,85 \\
Evangélicos de Missão & 2,36 & 2,93 & 2,54 \\
Evangélicos Pentecostais & 6,18 & 14,6 & 22,13 \\
Outros & 6,04 & 6,19 & 8,75 \\
Sem religião & 6,5 & 9,23 & 9,73 \\
TOTAL DA POPULAÇÃO & - & 17.876 .997 & 19.683 .975 \\
\hline
\end{tabular}

FONTE: Censo Demográfico IBGE, 1991, 2000 e 2010. Elaboração própria.

TABELA 3.3 - GRUPOS RELIGIOSOS NO BRASIL

\begin{tabular}{lcccc}
\hline RELIGIÕES (EM \%) & 1980 & 1991 & 2000 & 2010 \\
\hline Católicos & 89 & 83,30 & 73,60 & 65 \\
Evangélicos de Missão & 3,40 & 3 & 4,10 & 4 \\
Evangélicos Pentecostais & 3,20 & 6 & 10,70 & 18,20 \\
Outros & 2,80 & 3 & 4,30 & 4,80 \\
Sem religião & 1,60 & 4,70 & 7,40 & 8 \\
TOTAL DA POPULAÇÃO & 119.009 .778 & 146.815 .795 & 169.872 .856 & 19.683 .975 \\
\hline
\end{tabular}

FONTE: Censo Demográfico IBGE. 1991, 2000 e 2010. Elaboração própria

A Tabela 3.2 revela que o catolicismo foi a religião que mais perdeu número de fiéis nas últimas décadas. Apesar disso, é ainda a religião com maior número de membros na RMSP $56,85 \%$ da população se declarou católica em 2010. Revela também o intenso crescimento dos evangélicos, sobretudo os pentecostais. Para o Brasil como um todo, os números não são muito diferentes, como demonstrado na Tabela 3.3 .

99 Um estudo realizado pelo Centro de Estudos da Metrópole (CEM) demonstrou esse trânsito religioso, revelando que na RMSP, no primeiro semestre de 2003, uma em cada três pessoas já havia mudado de religião (ALMEIDA, 2004). 
O Censo de 2010 mostra que 22,2\% dos brasileiros se declararam evangélicos. Basta analisar a série histórica para perceber a intensa expansão dos que se declaram evangélicos: em 2000 esse grupo representava $15,4 \%$ da população, em 1991 era $9 \%$ e, em 1980, apenas 6,6\% da população brasileira. Como visto na RMSP, os evangélicos se expandem em movimento oposto ao observado no catolicismo, que desde a década de 1990 registra quedas significativas em seu número de fiéis: em 2010, 64\% dos brasileiros professaram a religião contra os $91 \%$ registrados em 1970 . Se mantida essa tendência, na década de 2020 os católicos devem representar menos da metade da população brasileira, e na década de 2030 o número de evangélicos superará o de católicos (Gráfico 3.3).

GRÁFICO 3.3 - TRANSIÇÃO RELIGIOSA NO BRASIL

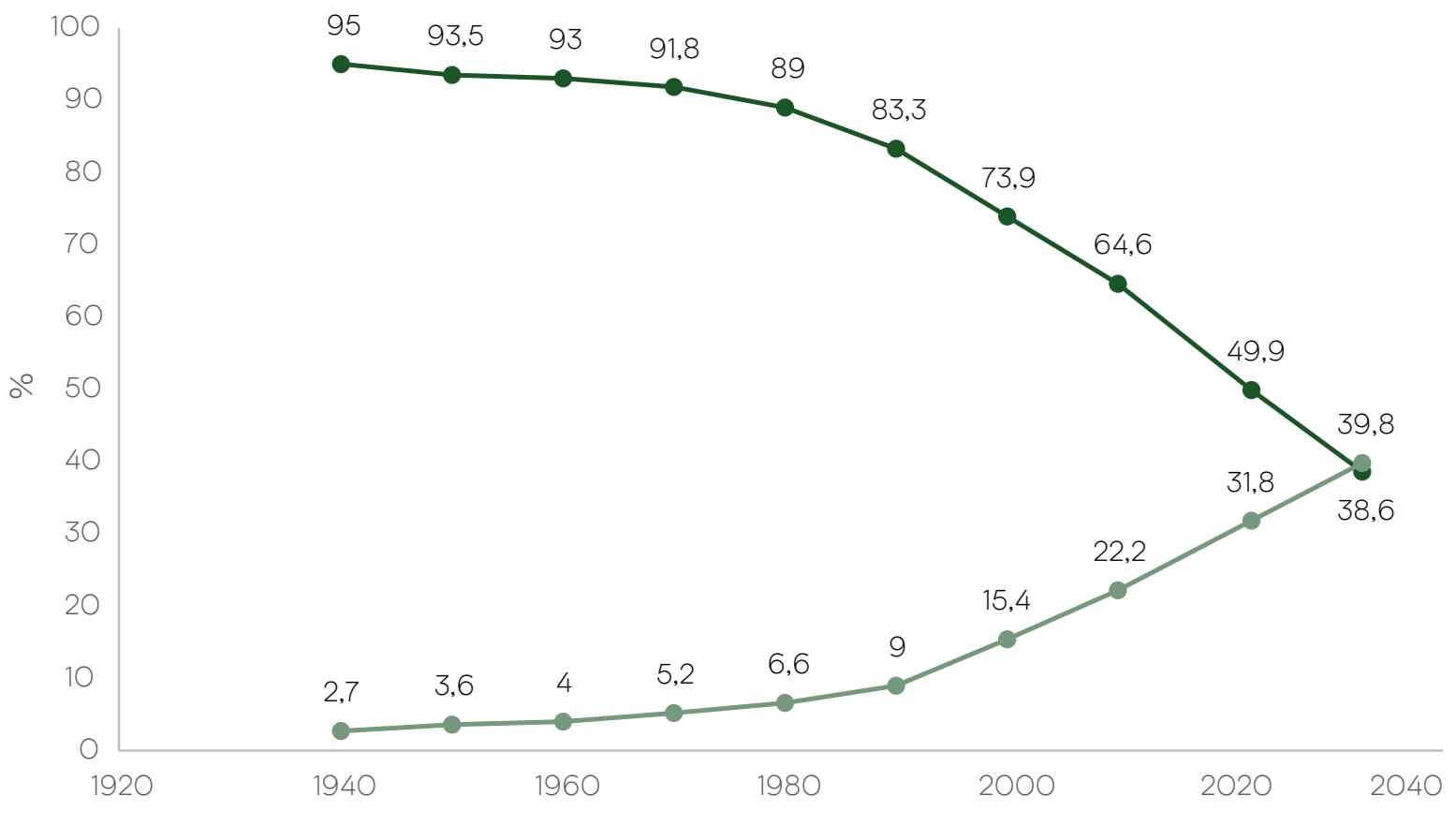

FONTE: Censo Demográfico IBGE 1940 a 2010 e, projeccōes de 2022 e 2032. Elaboração própria.

A multiplicação das alternativas religiosas encontra sua expressão máxima entre os evangélicos, uma vez que a fragmentação institucional é estrutural ao seu próprio movimento de expansão (ALMEIDA; MONTERO, 2001). Diferente da Igreja Católica que possui regras mais rígidas e estrutura hierárquica consolidada e central, a Igreja Evangélica não possui uma hierarquia sólida e tem flexibilidade de adaptação a diferentes contextos. $O$ processo de abertura de novas igrejas evangélicas tende a ser mais rápido que o de uma igreja católica, assim como a formação dos pastores. A formação de um padre católico dura, em média, oito anos e tem algumas exigências, como por exemplo o celibato. Já a formação dos líderes evangélicos varia bastante e tende a ser menos onerosa que a de um padre, podendo durar meses ou apenas semanas. Ao longo das últimas décadas, a facilidade de abrir novos templos têm favorecido a presença dos pentecostais e neopentecostais nas periferias das cidades brasileiras (QUEIROZ, 2O19).

Isso resulta em outra diferença que é em relação à capilaridade desses templos religiosos. Apesar das paróquias se instalarem no interior dos bairros, em geral estão localizadas nas vias principais, com projetos regulares, demorando mais para acessar os territórios de maior vulnerabilidade. Já os templos e sedes das igrejas evangélicas têm estrutura física bastante distinta, podendo se instalar em imóveis irregulares, sem projeto arquitetônico específico ou mesmo acabamento, se instalando muitas vezes em "garagens" ou espaços equivalentes. Os templos da Assembleia de Deus, por exemplo, têm grande capilaridade no interior dos bairros e favelas, desempenhando várias atividades que ultrapassam o campo da religiosidade (Figuras 3.2 e 3.3).

$\mathrm{O}$ aprofundamento do pluralismo religioso, entre outros motivos, se deve à perda da centralidade da Igreja Católica na estruturação da vida social brasileira (PIERUCCI, 1997). Nas décadas anteriores, comumente as pessoas se autodeclararam católicos

FIGURA 3.2 - Templo da Assembleia de Deus na comunidade Tavares Bastos, no Rio de Janeiro.

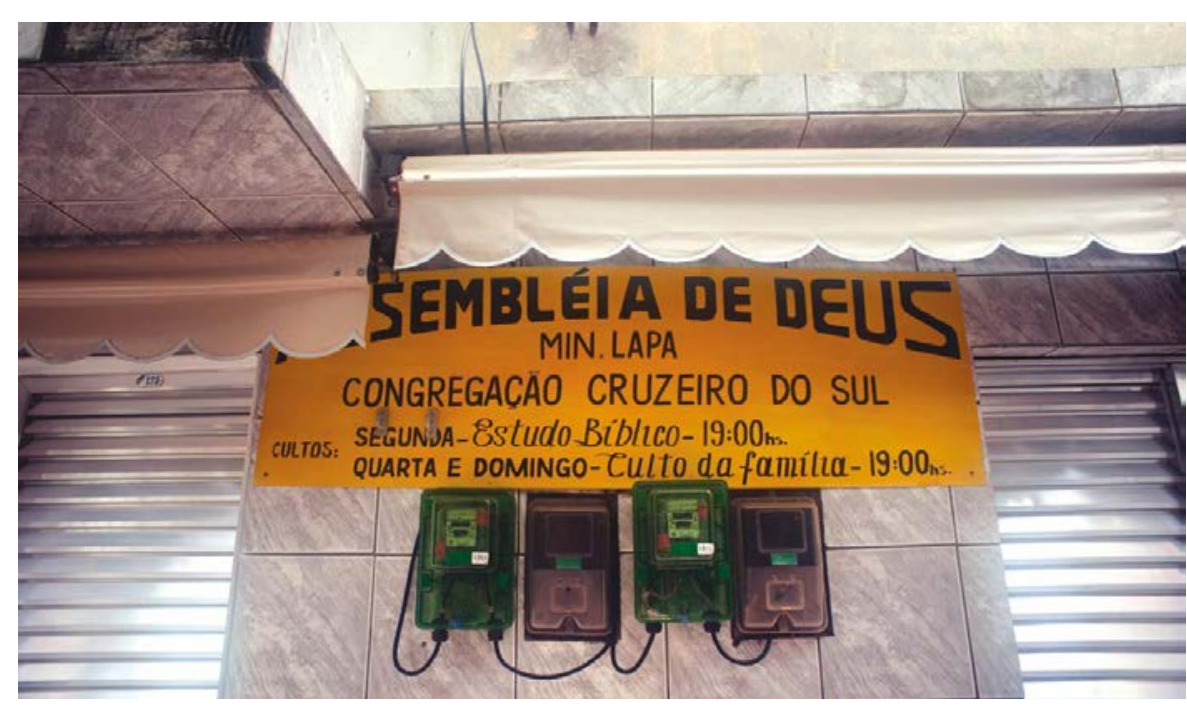


FIGURA 3.3 - Igreja Assembléia de Deus. Em São Roque (SP). abril de 2021.

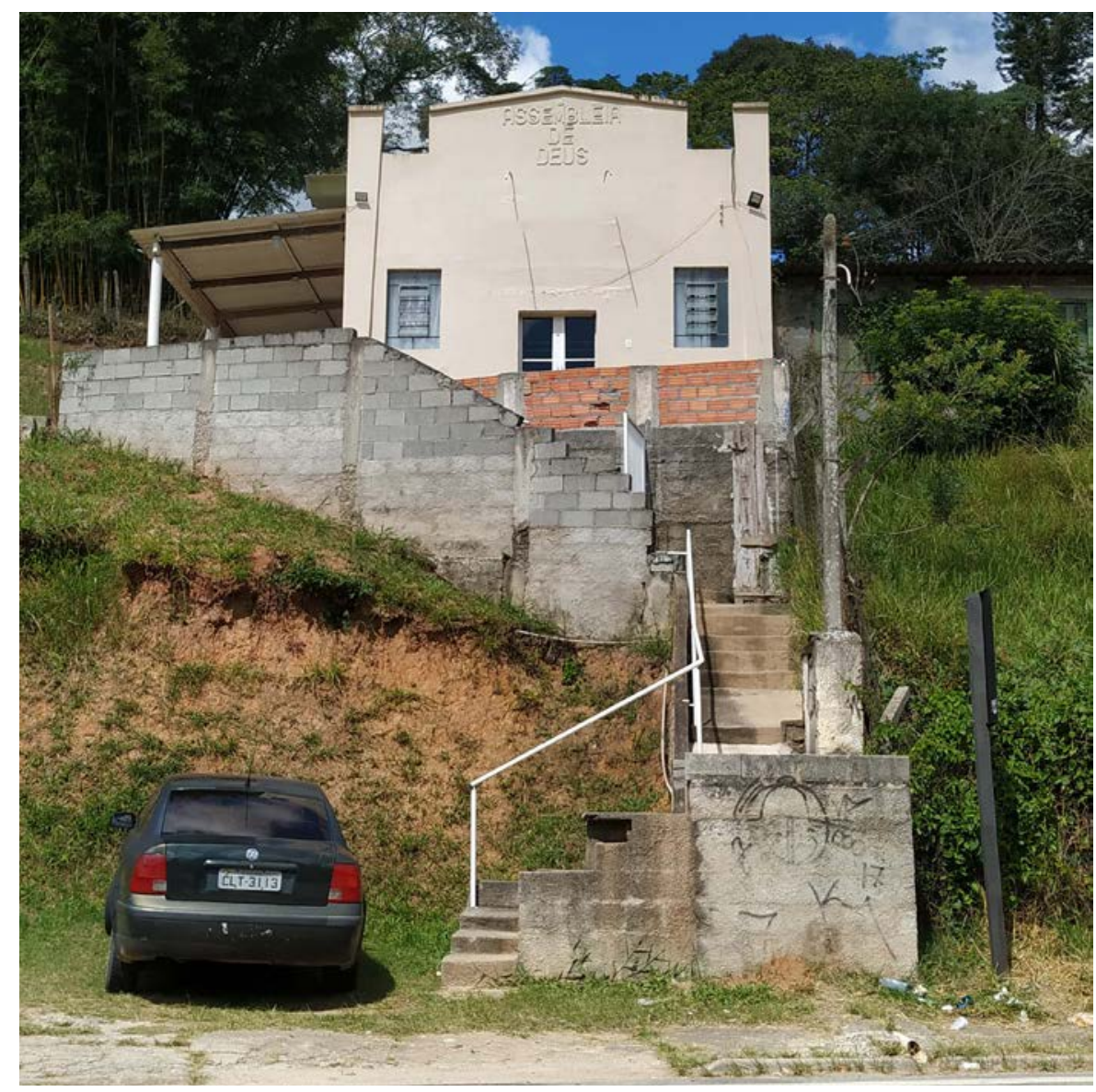

como se estivessem se identificando como brasileiros (ALMEIDA, 2004). Desse fenômeno surgem os termos "praticante" e "não praticante", categorias sociologicamente pouco precisas, mas com uma auto-identificação significativa ao separar os católicos quem mantém um vínculo com a comunidade os rituais, daqueles que se limitam aos casamentos, batizados e missas de sétimo dia (ALMEIDA; MONTERO, 2001). E, ainda, muitos se autodeclaravam católicos com receio de perseguição ou de preconceito caso declarasse sua religião, como por exemplo os kardecistas, um dos motivos de crescimento desse grupo nos últimos censos.

Apesar da diminuição dos fiéis católicos, a consolidação do movimento carismático conseguiu conter esse decrescimento ao promover a "readesão" do católico, como também pode ser entendido como uma resposta ao crescimento evangélico. Isso porque, apesar da Renovação Carismática estar inserida no interior do catolicismo, possui características semelhantes à religiosidade evangélica, ambas se baseando na doutrina da conversão. Significa práticas religiosas mais "espirituais", cuja experiência é mais emotiva, a partir de celebrações dinamizadas com mais música do que liturgia, e ainda a valorização de dons espirituais como o poder de cura. Portanto, segundo Almeida (2004), a religiosidade de muitos brasileiros tem adquirido cada vez mais tonalidades evangélicas, independente da religião professada.

III. “Patrão de si mesmo": expansão do empreendedorismo

É importante refletir sobre esse trânsito religioso, pois as religiões possuem um papel fundamental na elaboração do sentido de existência do sujeito, como também, em alguns casos, na organização da vida comunitária a partir da formação de redes de ajuda mútua e de solidariedade. Impactando, assim, de forma direta o cotidiano dos seus fiéis, seja nos discursos e nas respectivas visões de mundo. ${ }^{100} \mathrm{Um}$ exemplo disso são:

As redes evangélicas, trabalham em favor da valorização da pessoa e das relações pessoais, gerando um aumento de auto-estima e impulso empreendedor, além de ajuda mútua com o estabelecimento de laços de confiança e fidelidade. Essas redes atuam em contextos de carência, operando, por vezes, como circuitos de trocas, que envolvem dinheiro, comida, utensilios, informações e recomendações de trabalho, entre outros (ALMEIDA, 2004, p. 7).

Há uma certa reciprocidade entre os evangélicos de ajudar primeiro os "irmãos de fé", em geral não estendendo essa ajuda àqueles que pertencem a outra religião. Isso os diferenciam dos católicos, por exemplo, que são mais universalistas à medida que a religião a qual o indivíduo pertence não é um critério

100 Extrapolando inclusive o âmbito religioso ao impacłar a vida pública. Esse é o fenômeno que tem ocorrido no cenário politico brasileiro, já que nas últimas décadas os evangélicos neopentecostais têm aumentado sua participação na vida pública, transcendendo os "muros" das igrejas e ocupando um espaço crescente na politica, já que o pensamento de que o processo de secularização brasileira faria com que a religião ficasse restrita à esfera privada e individual não corresponde à realidade recente. Desse modo, o pentecostalismo, a cada ano, alcança as dimensões da vida pública, disputando espaço no cenário público brasileiro. Segundo a antropóloga Montero (QUEIROZ, 2O19), o secularismo brasileiro passa por um processo de reconfiguração marcado pela expansão das igrejas evangélicas e sua influência crescente na esfera pública e na politica do pais. Há um aumento da presença desse grupo religioso em espaços institucionais como a Câmara dos Deputados e o Executivo, tendo sua expressão máxima com a eleição de Jair Bolsonaro em 2018. Com retórica de extrema direita, o candidato foi eleito com significativa importância do voto evangélico. 
de seleção. Outra diferença é a maneira como ressignificam as desigualdades sociais, pois enquanto parte da religiosidade católica (a considerada progressista) é mais voltada para a ação social que questione e busque atingir as causas estruturais da pobreza, a religiosidade evangélica (em geral, pentecostal) in terpreta as dificuldades materiais e as desigualdades sociais como consequência individual, de ordem moral e/ou espiritual sendo que a solidariedade e ajuda entre os irmãos de fé podem amenizar essas dificuldades, mas o indivíduo deve buscar meios pessoais de superar essa situação.

A narrativa católica tem uma perspectiva mais a longo prazo, com sentido de sacrificar-se agora para o futuro, mesmo que seja para as próximas gerações ou para alcançar a "vida eterna". Feltran (2018) mostra que entre 1950 e 1990 a religiosidade católica foi um traço fundamental da visão de mundo e de futuro das famílias moradoras das periferias da cidade de São Paulo. Mesmo diante da pobreza e das dificuldades do dia-a-dia, os moradores tinham o ideal de integração social na metrópole:

A marca do projeto de melhoria, na teologia católica, é o longo prazo - o sacrifício resignado de agora é a chave para a redenção no futuro, talvez apenas após a morte. Mas, como sujeito da migração é familiar, comunitário, o sacrifício de um ajuda o outro, mesmo que apenas na próxima geração (FELTRAN. 2018, p. 131-132).

Diferentemente, a narrativa pentecostal defende "o agora", "o imediato", sendo a recompensa ainda em vida, oferecendo respostas mais concretas aos problemas cotidianos e trazendo a promessa de prosperidade divina para o presente. Baseia-se na Teologia da Prosperidade, que se conecta diretamente lógica neoliberal, pois em ambos há a defesa da meritocracia em que os problemas sociais não são vistos como ocasionados pelo sistema econômico, mas pela falta de esforço individual. Como colocam Dardot e Laval (2016), o neoliberalismo é uma racionalidade que conduz não somente os governantes, mas também os governados.

Dessa maneira, no final do século XX, é possível falar na constituição de um "sujeito empresarial", que segundo os autores pode ser definido como aquele que "deve maximizar seus resultados, expondo-se a riscos e assumindo inteira responsabilidade por eventuais fracassos" (DARDOT; LAVAL, 2016, p. 328).

É importante dizer que essa razão neoliberal, marcada pelo discurso meritocrático, individualista e competitivo, não é um fenômeno exclusivo das periferias, pois acomete a sociedade como um todo. Mas é fato que a expansão das igrejas pentecostais, a partir dos anos 1990, vai estimular esse ideário neoliberal nesses territórios.

Ao se converter, o indivíduo poderá prosperar a partir do seu esforço individual, com objetivo não somente de sobrevivência financeira, mas de acúmulo material e mobilidade social. As igrejas evangélicas, para além de uma rede de apoio, têm o papel de encorajar e estimular seus membros, pois perante as dificuldades e adversidades do dia a dia não cabe desistência ou desânimo, mas fé e atitude (ALMEIDA, 2019).

Assim, pouco a pouco, a apropriação particular da religião foi se disseminando, sendo que seus seguidores muitas vezes são motivados por questões pessoais ou familiares, com valores pautados na prosperidade e sucesso individuais como sendo desejo de Deus para os cristãos. As demandas sociais e a luta coletiva, tão presentes nas décadas passadas, começaram a perder o sentido, já que problemas sociais passaram a ser vistos como problema espiritual e de ordem individual. ${ }^{101}$

Esse trânsito religioso envolveu a sociedade como um todo, mas ocorreu de maneira mais acentuada na população de baixa e média escolaridade e renda, que migraram principalmente para o pentecostalismo (ALMEIDA, 2004). Isso somado à capilaridade das igrejas evangélicas impacta diretamente o cotidiano dos moradores de periferias, que a partir da pregação de uma Teologia da Prosperidade, passam a ter uma visão meritocrática e empreendedora. A narrativa "anti patrão" e "seja patrão de si mesmo" foi muito disseminada a partir dessas igrejas.

Em 2017, a Fundação Perseu Abramo realizou a pesquisa "Percepções e valores políticos nas periferias de São Paulo" com o intuito de "compreender, de forma profunda e detalhada, os elementos que têm formado a visão de mundo e o imaginário social

101 Mano Brown adverte sobre o conservadorismo e o individualismo que chegou às periferias e contesta os discursos moralistas vigentes, dizendo: "Hoje, a luta que as pessoas dizem ter é individual. Não vejo mais luta de classes. A luta é por conforto. A periferia está pedindo segurança, votando em policia, se escondendo dentro de igreja e atrás de pastor, não assumindo a parte que the cabe" (MANO BROWN, 2O18, s/p). 
nas periferias da cidade de São Paulo". A pesquisa demonstrou "uma intensa presença dos valores liberais do "faça você mesmo', do individualismo, da competitividade e da eficiência”, em um cenário de expansão das igrejas neopentecostais, do discurso do empreendedorismo e do consumo (FUNDAÇÃO PERSEU ABRAMO, 2017, s/p.), a partir de quatro resultados gerais:

1. Consumo: o capitalismo tenta desprover o cidadão de todos os elementos que constituem a identidade (cultura identidade de classe). O consumo torna-se um meio importante de constituição da identidade e materialização da ascensão;

2. Religião: de fato, a máxima 'Deus ajuda quem cedo madruga, quem se esforça mais' parece fazer sentido; Deus ajuda mais quem corre atrás, vai atrás dos sonhos, quem trabalha, quem se esforça;

3. Sobrevalorização do mercado em detrimento do Estado: há pouca valorização do público, tanto que quando podem acessar, querem colocar filho na escola particular ou pagar convênio médico. A política pública, em alguns casos, pode ser lida como desvalorização individual (por exemplo cotas). Os ideais comunitários e coletivistas praticamente não aparecem nas narrativas e, quando aparecem, restringem-se à dimensão da família, da vizinhança e da igreja:

4. Empreendedorismo: muitos desejam ser empreendedores e utilizam como justificativa as ideias de não ter patrão, te flexibilidade para gerir o próprio tempo, poder abrir o próprio negócio para trabalhar perto de casa, além da possibilidade de deixar patrimônio e herança para a família.

Já a pesquisa mais recente "Sonho da Favela 2020", realizada em dezembro de 2019 pelos institutos Data Favela e Locomotiva, em parceria com a Central Única das Favelas (CUFA) e a Comunidade Door, mostra claramente essa realidade, pois oito em cada dez moradores acreditavam que a vida iria melhorar em 2020 a partir do seu esforço individual e não por efetivação de políticas públicas. De acordo com a pesquisa $64 \%$ do total de entrevistados entendia que a melhoria de vida dependia de si mesmo, enquanto apenas $5 \%$ deles atribuíam a mudança ao governo federal. E, ainda, profissionalmente, o principal sonho revelado pelos entrevistados foi o negócio próprio (o que corresponde $35 \%$ dos entrevistados). Tornar-se empreendedor era a principal expectativa profissional para os moradores de mais de 60 favelas de todas as unidades da federação do país, onde essa pesquisa foi realizada. No âmbito pessoal a principal aspiração era a conquista da casa própria, enquanto que o principal desejo para o território onde moram era a segurança, o que correspondia a $30 \%$ dos entrevistados, seguido de $17 \%$ que sonham com mais infraestrutura e $12 \%$ com melhor acesso à saúde. Segundo Renato Meirelles, presidente do Instituto Locomotiva, "O grande sonho da favela é a segurança. E quando a gente fala em segurança estamos falando de sair de casa sem achar que você pode morrer por uma bala perdida dentro do território" (JUCÁ, 2019, s/p).

\subsection{PÓS ANOS 2000: HETEROGENEIDADE} DAS PERIFERIAS

A década de 2000, resultado das mobilizações das décadas passadas, foi marcada por importantes conquistas como a aprovação do Estatuto da Cidade (2001), a criação do Ministério das Cidades (2003) e a aprovação da Lei Federal 11.888 (2008), que assegura às pessoas de baixa renda assistência técnica pública e gratuita para o projeto e a construção de habitação de interesse social.

Apesar dessas conquistas, o chão da realidade das periferias era outro, descrito por alguns autores como "exílio na periferia" (MARICATO, 2000; SANTOS, 1990). Expressão utilizada para explicar as condições de isolamento a que os moradores das periferias estavam submetidos, com transporte público deficiente e carência de infraestrutura e equipamentos públicos (Figuras 3.4 e 3.5). Fenômeno que Kowarick (2009) chamou de vulnerabilidades socioeconômicas e civis, pois:

Refere-se à situação de desproteção que vastas camadas pobres encontram-se submetidas no que concerne às garantias de trabalho, saúde, saneamento, educação e outros componentes que caracterizam os direitos sociais básicos de cidadania. Entre eles, destaca-se a questão habitacional, que não pode ser reduzida apenas à qualidade da moradia, aspecto importante, mas não único, pois implica também a sua localização. [.] Esse é o lado socioeconômico da vulnerabilidalizaçaco. fir outro lado, a vulnerabilidade civil, refere-se à integridade fisica das pessoas, ou seja, ao fato de vastos segmentos da população estarem desprotegidos da violência praticada por bandidos e pela polícia (KOWARICK, 2009, p. 19). 

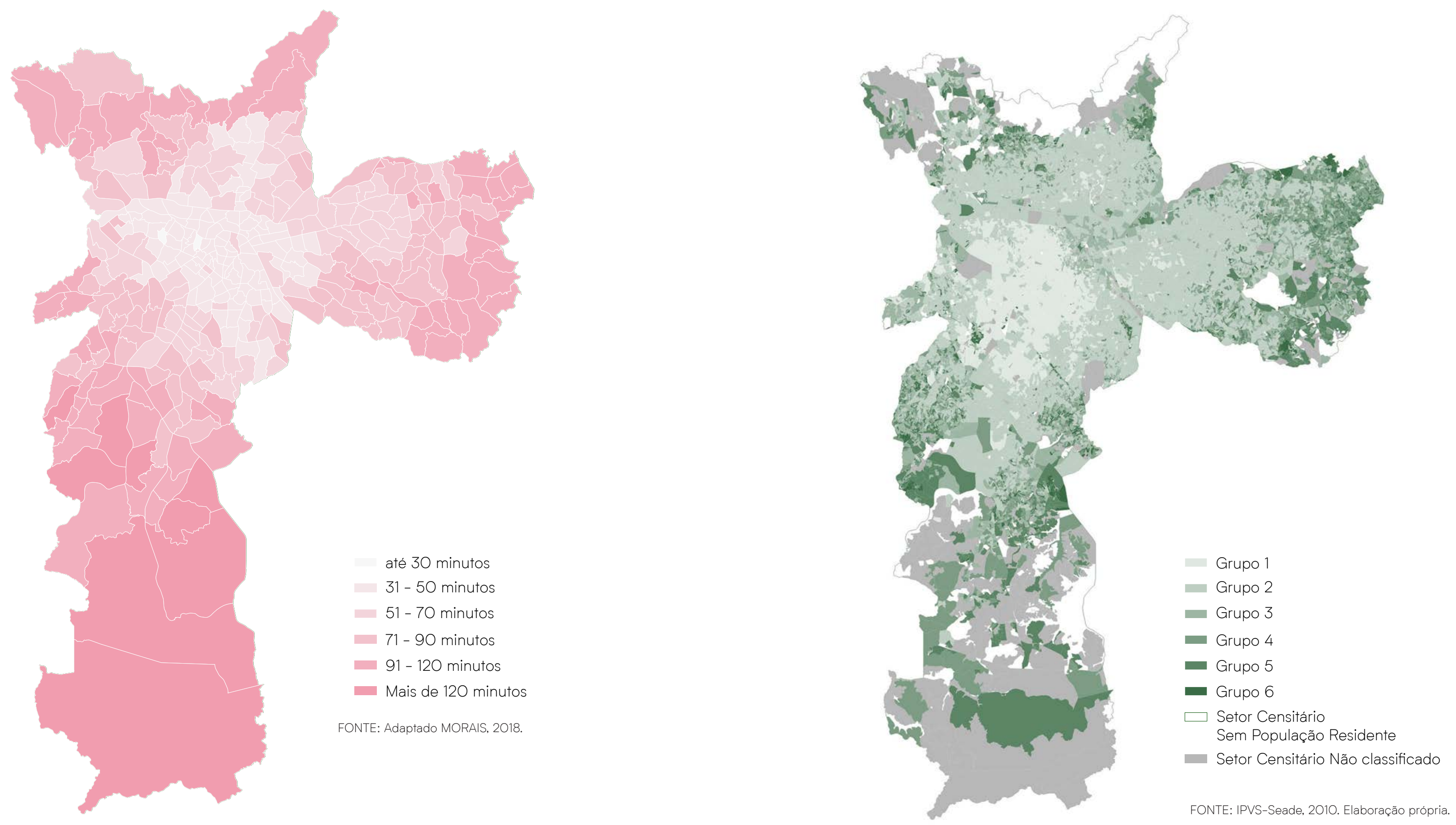
Dessas árduas condições de vida, a partir das periferias, emergiram diversos coletivos e redes (MORAIS, 2018). Segundo D’Andrea (2013), a explosão desses coletivos, muitas vezes artísticos, é resultado dessa condição de "exílio na periferia", ou seja, está relacionada ao contexto histórico da década de 1990, descrito aqui como "Holocausto Urbano", contexto de crise socioeconômica, guerra como rotina, perda de espaços e enfraquecimento das CEBs.

Seguindo o processo já iniciado na década de 1990, parte dos militantes afastaram-se das periferias, o que resultou na institucionalização de canais de participação popular, ou seja, parte da base se burocratizou, deixando assim de se movimentar. Quando a força progressiva alcançou o Governo Federal, o poder local foi esvaziado. Nesse sentido, Maricato (2014, p. 153) escreve que '[...] a esfera institucional parece ter 'engolido' as forças sociais antes mobilizadas contra ela". E preciso reconhecer que esse não é um processo generalizado, pois há exceções como as assessorias técnicas que continuaram contribuindo na luta social dos moradores de periferias, muitas vezes trabaIhando em parceria com os movimentos de luta por moradia. Portanto, seria um erro dizer que o trabalho de base acabou, porém reconhece-se que as periferias passaram por alterações, até mesmo a inserção de "novos atores sociais", como visto no tópico anterior, com perda de espaço de formação política.

Nesse sentido, é possível dizer que nas periferias existiram dois ciclos de insurgência política: (1) militante, iniciado durante os anos de 1970 e 1980, ligado às CEBs e formação de partidos políticos (como o Partido dos Trabalhadores), sendo as pautas relacionadas às conquistas de direitos; (2) ativista, iniciado a partir dos anos 2000, ligado ao surgimento de redes e coletivos, com pautas mais relacionadas à cultura (GOHN, 2017; MORAIS, 2018).

Morais (2018) faz um comparativo entre esses dois ciclos, já que se o ciclo da militância buscava a construção da noção do direito a ter direito, ou seja, a conquista dos direitos, o ciclo ativista é marcado pela luta da efetivação dos direitos constitucionais que não foram garantidos a todos, sobretudo aos moradores de periferias. É possível dizer também que se trata de uma estrutura mais fluida e horizontal, com pautas mais particulares e po vezes temporárias, autocentradas em uma categoria e grupo social. Esse ciclo se constitui como uma pluralidade de movi- mentos com temas ligados a gênero, raça, cultura e juventude, fora de partido e sindicatos (muitas vezes rejeitando-os) e por isso de difícil definição.

D’Andrea (2013) afirma que a insurgência desse ciclo não parte de atores externos, mas se dá de dentro para fora das periferias, a partir dos sujeitos periféricos. Se no contexto das CEBs se tinha a presença de membros da igreja, dos partidos ou dos sindicatos, no ativismo são os próprios moradores, em geral os jovens, que se orgulham da condição de periférico e agem politicamente a partir disso, com "[...] senso crítico com relação à forma como a sociedade está estruturada" (D’ANDREA, 2013, p. 175). Portanto, são questões amplas e estruturais da sociedade, como o genocídio da juventude negra, falta de oportunidade para os jovens, condições de desigualdade e segregação socioespacial (MORAIS, 2018). Atualizando a definição de Sader (1988), seriam os "novíssimos" personagens que entraram em cena (GOHN, 2014).

A diferenciação entre esses dois ciclos não é rígida, na verdade ocorre um certo "hibridismo" entre eles (MORAIS, 2018). Isso porque a passagem de um para o outro se dá a partir da ressignificação das lutas travadas pelos moradores de periferias, não existindo, portanto, dicotomia, mas uma resposta ao contexto em que estão inseridos (MARINO, 2016). Esses ciclos "se transmutam um no outro se contaminando, enredando coletivos, pautas, e, em diversos momentos, migrando táticas e estratégias militantes em ativistas e vice-versa" (NEVES et al., 2018, p. 230).

O contexto de insurgência desse segundo ciclo é marcado, sobretudo, por dois fenômenos: o esvaziamento político e o neoliberalismo (MORAIS, 2018). A respeito do esvaziamento político é possível dizer que a Constituição Federal permitiu maior participação da sociedade civil na tomada de decisões das políticas públicas, "a militância no poder", mas ao mesmo tempo houve uma diminuição da reivindicação de direitos e de protestos populares, com significativa redução das iniciativas de formação e construção de consciência crítica. Esse processo se deu junto à perda de espaços das CEBs, como também ao esvaziamento de ações de formação política ligadas, por exemplo, ao PT. A mesma base de onde nas décadas de 1970 e 1980 fez emergir das periferias a considerada "renovação política", ou ainda, uma nova forma de cidadania (HOLSTON, 
2013) foi absorvida pela institucionalidade. ${ }^{102}$ Passam a atuar a partir da lógica clientelista, que tanto criticaram no passado (MORAIS, 2018).

Com a inserção do ideário neoliberal nos anos 1990 e sua consolidação no pós 2000, houve o enfraquecimento do Estado, com a consolidação de "[...] um projeto de Estado mínimo que se isenta progressivamente de seu papel garantidor de direitos, através do encolhimento de suas responsabilidades sociais e sua transferência para a sociedade civil” (DAGNINO, 2004, p. 96).

A coexistência desses dois fenômenos corresponde ao que a autora Dagnino (2004) chama de "confluência perversa", à medida que dois projetos que a princípio seriam antagônicos (um democratizante/participativo e outro neoliberal) utilizam a mesma base e as mesmas referências, como por exemplo a sociedade civil, a democracia e a cidadania. É perverso porque sua utilização se dá de maneira confusa, obscurecendo seu real significado. Exemplo disso é a combinação contraditória de uma agenda neoliberal com as políticas sociais de alto impacto do Governo Lula (2003-2010) (PAULANI, 2017). Apesar do seu Governo ter desacelerado as privatizações comuns no Governo de Fernando Henrique Cardoso (1995-2003), instituído políticas importantes como o Bolsa Família, Luz para Todos, Programa Universidade para Todos (Prouni) e Fundo de Financiamento Estudantil (Fies), como também aumento real do salário mínimo, seu mandato não reverteu a agenda neoliberal, mas sim "a manutenção e mesmo reforço da institucionalidade voltada prioritariamente à acumulação financeira [...] acompanhada de políticas sociais de alto impacto" (PAULANI, 2017, p. 96).

Durante os anos 2000, essas políticas sociais instituídas nos governos petistas de Lula e Dilma tiveram efeitos diretos nas periferias, com significativa redução na pobreza (a partir do Programa Bolsa Família), como também diminuição da desigualdade (com elevação do valor real do salário mínimo). Essas mudanças sociais resultaram na emergência da classe "C" ou da assim chamada "nova classe média dos anos 2000 no Brasil”, já que, como demonstrado pela Tabela 3.4, a mobilidade

102 Holston (2013, p. 326) explica que essa nova forma de cidadania, sem antecedentes na historia da democracia brasileira, se deu pela "participação civica insurgente iniciada nos bairros empobrecidos auto construidos das periferias, na ilegalidade e na desigualdade", gerando assim "uma transformação nacional da cidadania". social das camadas inferiores em direção à massa trabalhadora e à baixa classe média foi espantosa, enquanto que da classe média para cima o dinamismo arrefeceu substancialmente (QUADROS, 2010). ${ }^{103}$ Se antes Mano Bown descreveu as condições das periferias como Holocausto Urbano, em 2018 em uma entrevista disse: "não é como nos anos 90, quando faltava comida nas mesas” (MANO BROWN, 2O18, s/p.)

TABELA 3.4 - BRASIL, PESSOAS OCUPADAS

\begin{tabular}{lcccc}
\hline ESTRATOS SOCIAIS & \multicolumn{2}{r}{2000} & \multicolumn{2}{c}{2010} \\
& No PESSOAS (MIL) & $\%$ & No PESSOAS (MIL) & $\%$ \\
Alta Classe Média & 4.803 & 7.3 & 6.396 & 7,4 \\
Média Classe Média & 6.215 & 9,5 & 9.223 & 10,7 \\
Baixa Classe Média & 16.486 & 25,1 & 31.246 & 36,2 \\
Massa Trabalhadora & 18.214 & 27,8 & 26.649 & 30,9 \\
Miseráveis & 19.912 & 30,3 & 12.840 & 14,9 \\
TOTAL & 65.630 & & 86.354 & \\
\hline
\end{tabular}

FONTE: Censo Demográfico IBGE, 1991, 2000 e 2010. Elaboracăo próoria

A confluência entre o Programa Bolsa Família e o aumento do salário mínimo culminou no aumento do consumo pela população de baixa renda, potencializado pela possibilidade do pagamento parcelado no crediário. Apesar dessas políticas so-

O3 Sobre a mobilidade social nesse período, de acordo com Quadros (2010, s/p.): "a expansão da alta classe média representa a oportunidade de ascensão para 2,5 milhões das pessoas que em 2003 encontravam-se na média classe média. Desconsiderando o crescimento populacional, este canal equivale a 9\% das mesmas. Já para os 53,2 milhões de pessoas que estavam na baixa classe média em 2003 , o espaço para ascensão foi de 10,4 milhões acumulando-se a expansão da alta e da média classe média, o que equivale a 14,5\% do contingente inicial. Assim, para a numerosa parcela da população que já se encontrava na baixa classe média, a mobilidade ascendente foi bem menos expressiva do que é sugerido quando se enfatiza apenas o seu crescimento de $37,4 \%$. Seguindo esta linha de raciocínio, é na massa trabalhadora pobre que o espaço potencial para a ascensão foi de fato significativo, equivalendo a $45,5 \%$ das pessoas que estavam nesta camada em 2003. Entretanto, no estrato social aqui denominado de miseráveis, as melhorias foram ainda mais surpreendentes, abrindo-se um inusitado canal para a ascensão de uma massa equivalente a $61 \%$ das pessoas que em 2003 encontravam-se nesła situação, sempre desconsiderando o crescimento populacional. Por tudo isso, fica evidente que se, nas camadas inferiores, a mobilidade social em direção à massa trabalhadora (pobre) e à baixa classe média (remediada) foi realmente espantosa, da baixa classe média para cima, o dinamismo arrefeceu substancialmente." 
ciais terem permitido maior acesso ao consumo, possibilitaram também acesso aos serviços básicos, em um combinado com ganhos do capital. O que ocasionou a expansão dos mercados nas periferias, a inserção de circuitos globalizados com a chegada de mercadorias estrangeiras e a abertura de pequenos a grandes comércios inexistentes até então apenas nas áreas centrais (Figura 3.6).

FIGURA 3.6 - Respectivamento, empregos formais nos setores de Comércio, Serviços e Indústrias de Transformação em 2000 e 2016.
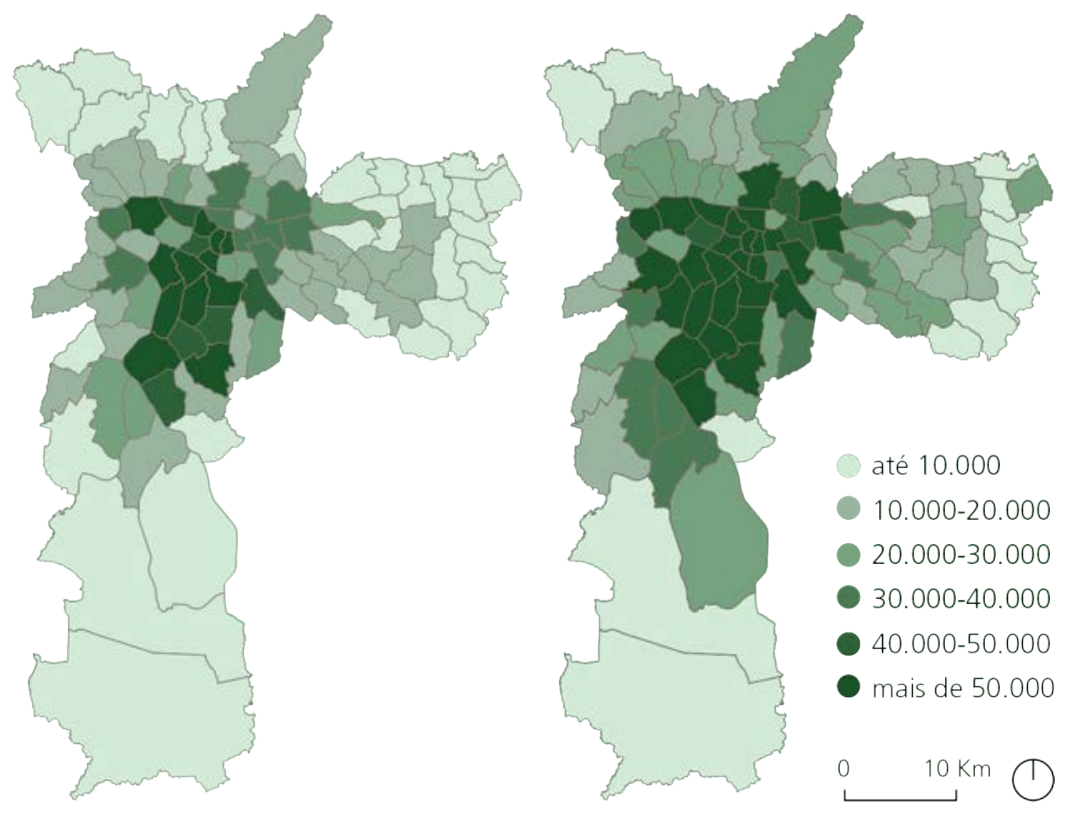

FONTE: MORAIS, 2018, p. 62

Telles (2009) descreveu esse processo como extensão das fronteiras urbanas e incentivo ao empreendedorismo popular. A autora coloca que as fronteiras entre legal-ilegal, formal-informal, lícito-ilicito são embaralhadas, porosas, incertas e tênues, pois mercadorias e pessoas transitam e se deslocam permanentente entre elas. $\mathrm{O}$ trabalhador urbano contemporâneo, por exemplo, está inserido "de forma descontínua e intermitente, das oportunidades legais e ilegais que coexistem e se superpõem nos mercados de trabalho" (TELLES, 2009, p. 157). Enquanto que os produtos globalizados circulam "nos múltiplos circuitos do comércio ambulante por onde circulam produtos de procedência conhecida, desconhecida, duvidosa ou ilícita, para então se condensar nas miríades de pontos de venda espalhados pela cidade" (TELLES, 2009, p. 154). A autora coloca ainda que isso é um ponto de ancoramento do capitalismo que mobiliza os empobrecidos enquanto clientes e consumidores e assim garante a circulação e distribuição de mercadorias, que sem essas fronteiras porosas não chegariam aos lugares mais pobres do planeta. Nas palavras da autora:

Disso temos as evidências na expansão mais do que considerável dos mercados de consumo popular, que apresentam uma densidade notável no centro da cidade, mas que se expandem igualmente nos bairros periféricos em mercados locais apoiados em uma trama variada tecida nas fronteiras incertas do informal, do ilegal e do ilícito (TELLES, 2009, p. 168).

Sobre as mudanças demográficas ocorridas na Região Metropolitana de São Paulo, Marques (2014) pontua o aumento da escolaridade nos bairros periféricos e a redução de classes manuais e aumento das classes profissionais. Sobre a escolaridade, de 2000-2010 houve um aumento significativo da população de baixa renda acessando o ensino superior, resultado de: (1) políticas sociais como ProUni, Fies e cotas nas universidades federais - inclusive, possibilitada pelos "militantes" no poder; (2) expansão de universidades privadas e incentivo do acesso da população da "baixa classe média", considerando essa parcela da população como possibilidade de expansão dos seus negócios.

Do ponto de vista do acesso à infraestrutura, as periferias também passaram por mudanças estruturais nas últimas décadas. Morar nesses territórios já não é igual ao século passado: de acordo com dados do Censo de 2010, no Brasil, $88 \%$ das habitações são servidas por rede pública de água, $56 \%$ por rede de esgoto, $76 \%$ têm algum tipo de coleta de lixo e $72 \%$ usufruem de energia elétrica (PASTERNAK-TASCHNER; D'OTTAVIANO, 2016).

Ainda sobre as mudanças ocorridas após os anos 2000, é importante citar as manifestações de "Junho de 2013", que foi uma onda massiva de protestos e reivindicações com reunião pautas diversas. Entre elas: o Movimento Passe Livre, o mau uso do dinheiro público no âmbito da Copa do Mundo (2014), a precarização do trabalho, como também a bandeira de luta do direito à cidade defendida pelos movimentos de luta por moradia. É importante destacar que essas manifestações trouxeram à cena pública novos movimentos de direita, como por exemplo o Movimento Brasil Livre (MBL) e o Movimento Vem Pra Rua, que encabeçaram as manifestações em prol 
do impeachment da ex-presidenta Dilma Rouseff e buscam fortalecer o projeto de Estado neoliberal.

Podemos pensar essas manifestações como um terremoto [...] que perturbou a ordem de um país que parecia viver uma espécie de vertigem benfazeja de prosperidade e paz, e fez emergir não uma, mas uma infinidade de agendas mal resolvidas, contradições e paradoxos (ROLNIK, 2O13, p. 8).

Como pontua Morais (2018), na década de 2010 ocorre o fechamento de dois ciclos: (1) ciclo da Reforma Urbana, nomeado por Maricato (2014), que foi iniciado durante a ditadura militar com militantes lutando nas periferias, por exemplo, os arquitetos e urbanistas presentes nos bairros periféricos; (2) ciclo progressista no governo federal, iniciado com a eleição da candidatura petista de Lula em 2002 e findado com o golpe de 2016, no qual Dilma sofreu o impeachment, e consolidado com a eleição do candidato de extrema direita Jair Bolsonaro em 2018. ${ }^{104}$

O que se percebe a partir da breve recuperação realizada neste capítulo é que a sociedade ficou mais conservadora e moralista, resultado da confluência das novas matrizes discursivas e atores sociais e recuo das forças progressistas. Portanto, com o fechamento desses dois ciclos urge a necessidade de reconstrução do campo progressista brasileiro, a partir do chão da realidade das periferias e da potência transformadora da ação popular, e para isso é preciso compreender as transformações pelas quais passaram as periferias.

104 Concordo com Morais quando a autora diz que [...] após o baixo desempenho de candidaturas petistas nas periferias de São Paulo, parece haver. por parte do campo progressista, uma tendência em associar os moradores periféricos às igrejas neopentecostais, ao discurso meritocrático e ao conservadorismo, como se, em uma análise superficial, a teologia da libertação das décadas passadas tenho sido substituída pela teologia da prosperidade. Ainda mais, nas análises ainda mais superficiais, parece que há uma tendência em culpar as periferias, berço historicamente petista, pelo crescimento da extrema direita nos últimos anos no Brasil. Sobre isso, Gisele Brito (2018) integrante da Rede Jornalistas das Periferias, afirma que, de fato, talvez haja um crescimento do conservadorismo nos bairros periféricos nos últimos anos. mas destaca que estamos em um momento em que toda a sociedade esta se inclinando para a direita, elegendo candidatos conservadores como Donald Trump e Jair Bolsonaro como presidentes, respectivamente, dos Estados Unidos e do Brasil. Ou seja, o crescimento do conservadorismo não é um fenômeno periférico (MORAIS, 2018, p. 51).
Tendo esse objetivo no horizonte da pesquisa, buscou-se iluminar as mudanças nos anos 2000 com a ampliação do mercado de trabalho e de consumo, redução expressiva da taxa de mortalidade - e da "violência"-, maior acesso à infraestrutura e a bens e serviços, aumento da escolaridade, numa combinação entre mobilidade social e acumulação financeira. Dessa maneira, hoje é possivel dizer que as periferias paulistanas são mais diversificadas e heterogêneas, tendo passado por ressignificações de suas lutas sociais, inserção de novos atores sociais e criação de novas dinâmicas socioeconômicas.

A cidade deve então passar a ser entendida de maneira muito mais heterogênea, com diferenciações internas complexas, onde pobreza e riqueza se distribuem de maneira descontínuas e conformam um espaço fragmentado, que não cabe nas dualidades que muitas vezes buscam conceituar as periferias, ou ainda, as cidades (TELLES, 2006). Nesse dinamismo e diversidade reside a dificuldade de definição das periferias e a busca em superar visões dicotomizadas da cidade. Para contribuir nesse debate o próximo capítulo se deterá na análise da trajetória de uma ocupação recente, Jardim da União, como tentativa de contribuir para o debate sobre a produção contemporânea do espaço urbano. 
PÉ NO CHÃO DA REALIDADE:

\section{Jardim da União}

Ao trazer a trajetória do Jardim da União procuro refletir sobre a relação da luta social daqueles que reivindicam o direito à cidade e a produção atual do espaço urbano, portanto o sentido político dessa experiência urbana. Não há pretensão generalista, mas a partir de um "processo situado", ou seja, uma situação vivida no tempo e no espaço (TELLES, 2006) apontar especulações sobre a produção contemporânea da cidade. Através dos sinuosos caminhos desde a formação dessa ocupação até as diversas mudanças e intervenções, a ideia é refletir como se produz um território como o Jardim da União, quais os atores envolvidos e seus discursos, as relações de poder, disputas e negociações, atravessados por conflitos e tensões. E, ainda, quais as mudanças socioespaciais ocorridas ao longo dessa trajetória. Essas são algumas das questões mobilizadoras deste capítulo.

O Jardim da União é uma ocupação urbana localizada no distrito do Grajaú, Zona Sul, distanciado em aproximadamente 30 $\mathrm{km}$ da Praça da Sé/Centro, na cidade de São Paulo. Em um terreno de aproximadamente $84.750 \mathrm{~m}^{2}$, pertencente à recém-extinta Companhia de Desenvolvimento Habitacional e Urbano do Estado de São Paulo (CDHU). ${ }^{105}$ A ocupação está

Se o povo soubesse a força que ele tem. não aturava o desaforo de ninguém.

Música do Jardim da União

105 Segundo o site da CDHU, a Companhia de Desenvolvimento Habitacional e Urbano do Estado de São Paulo é uma empresa do Governo Estadual, vinculada à Secretaria da Habitação, que tem por finalidade executar programas habitacionais em todo o território do Estado, voltados para o atendimento exclusivo da população de baixa renda. O Projeto de Lei (PL) n॰ 529/2O2O, publicado no Diário Oficial do Estado de São Paulo no dia dia 13/08/2020, estabeleceu medidas voltadas ao ajuste fiscal e equilibrio das contas, que tinha como argumento a mitigação dos impactos causados pela pandemia do COVID-19 sobre as receitas públicas. Dentre as medidas propostas está a extinção da CDHU, com a transferência de suas atividades para a Secretaria de Habitação. A legislação previa o prazo de até seis meses para conclusão do processo de extinção, podendo ser prorrogado por igual periodo por mais duas vezes. Em março de 2020, o governo de São Paulo, chefiado por João Doria (PSDB), editou decreto estendendo o limite de atuação de outras empresas, mas deixou a CDHU de fora. Com a não prorrogação do prazo de ałuação, o fułuro da CDHU é incerto. 
FIGURA 4.2 E 4.3 - Acima, Renda domiciliar per capita e, abaixo, Vulnerabilidade Social no Jardim da União e entorno.

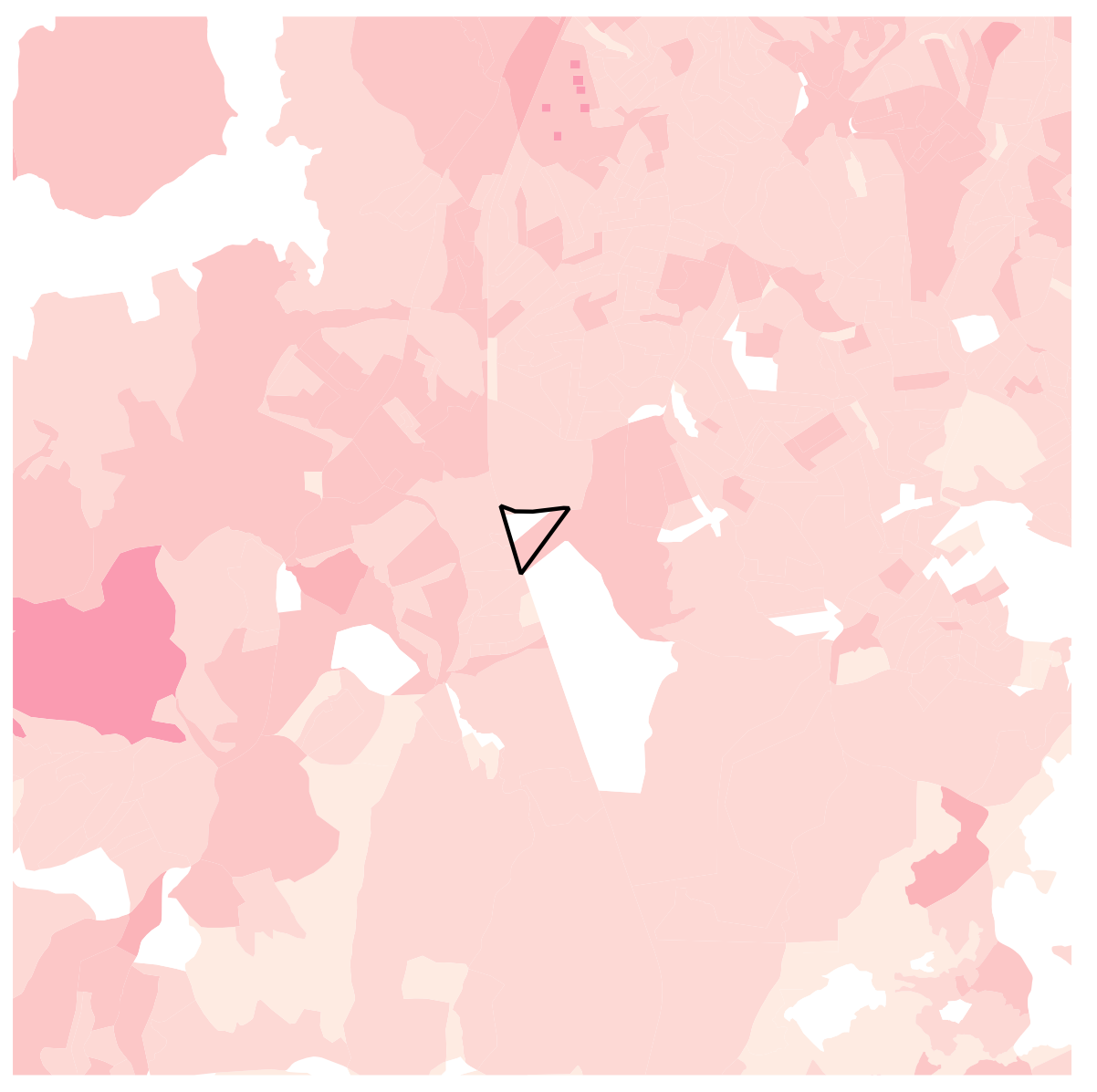

até $0,5 \mathrm{SM}$

- 0,51 a $1 \mathrm{SM}$

- 1,01 a 1,5 SM

1,51 a $2 \mathrm{SM}$

- 2,01 a $3 \mathrm{SM}$

Seja "SM" o salário minimo no ano de $2010, \mathrm{R} \$ 510.00$. FONTE: RAISMTE e Seade. 2010. Elaboração própria

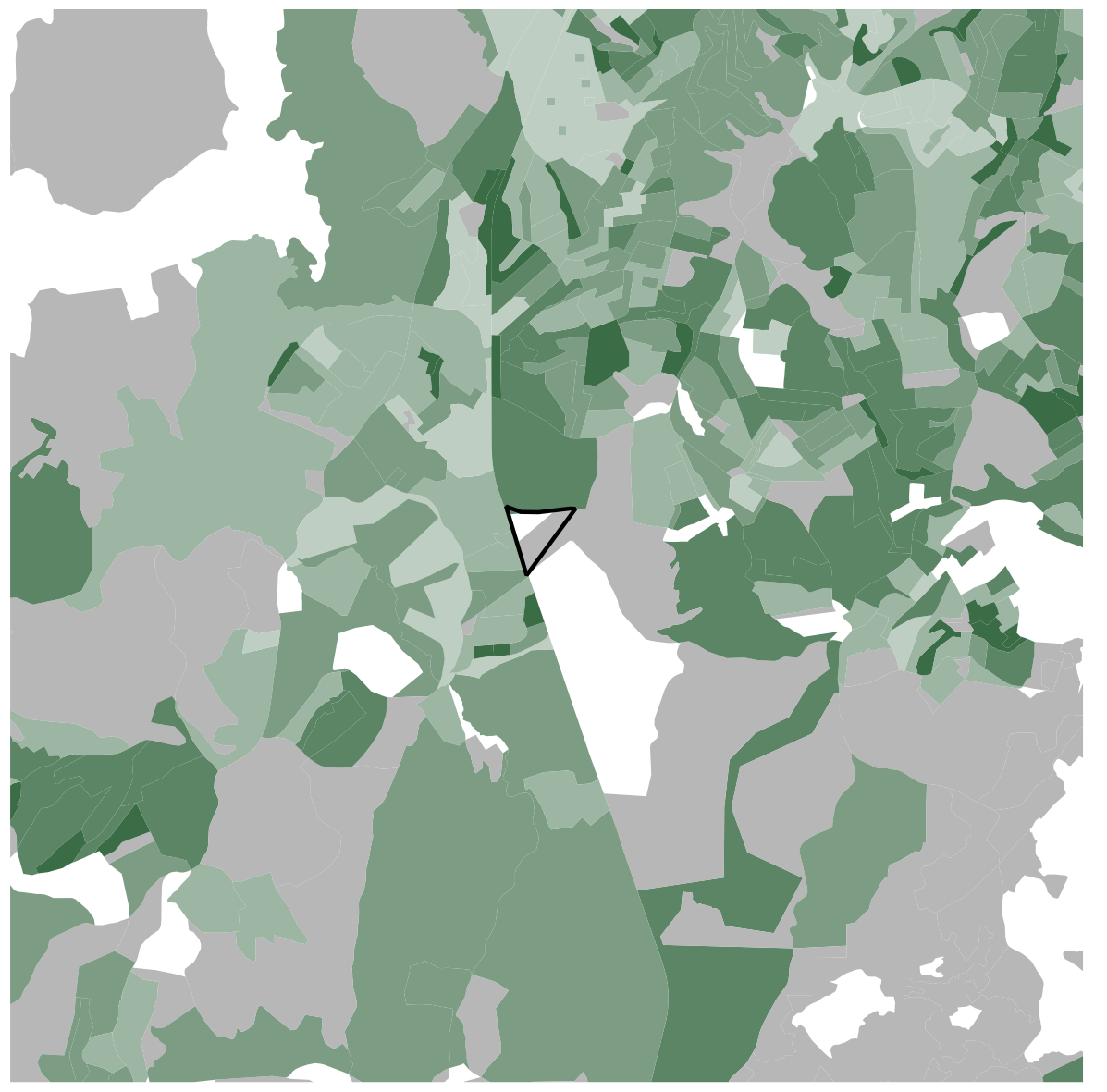

Grupo 2

Grupo 3

- Grupo 4

Grupo 5

- Grupo 6

Setor Censitário Sem População Residente

- Setor Censitário Não Classificado

Perímetro Jardim da União

\section{$0 \quad 0.51 \mathrm{~km}$}

FONTE: IPVS-Seade, 2010
Nesse sentido, diante da impossibilidade de pagar aluguel, diversos moradores expressam que nunca foi escolha morar em uma ocupação, ainda mais considerando as condições precárias e a insegurança da permanência, mas na ausência de outra alternativa foi a solução encontrada por eles na luta pelo direito à cidade. Fernanda conta que:

Cara, nunca foi opção sair de uma casa, acordei de uma hora pra outra e optei sair da moradia de alvenaria e fui morar debaixo de uma lona Nunca foi opcional pra ninguém (Fernanda.

CPPATHIS, 2019).108

\section{Já Teresa relata sua chegada até o Jardim da União:}

Fomos para o Itajaí, eu ainda pagava aluguel. Quando a gente sofreu a reintegração de posse que a gente veio pra cá [Jardim da União] eu falei: "ah não, eu não vou mais aguentar pagar aluguel, eu vou embora de vez pra ocupação.” Aí o Joaquim [o esposo] falou assim: mas você acha que vai dar certo? Eu falei: a gente tem que arriscar, é uma luta e vou enfrentar (Teresa, informação verbal, 2020).

Teresa se refere ao Itajaí pois inicialmente ocuparam um outro terreno na região do Itajaí, mas que após sucessivas ordens de despejo decidiram ocupar o terreno onde permanecem até hoje. ${ }^{109} \mathrm{O}$ despejo sofrido no Itajaí, com uso de força policial, não é um caso isolado, ou seja, que somente faça parte da trajetória do Jardim da União, mas algo cada vez mais recorrente na periferia paulistana. A figura 4.4 traz dados de ocupações localizadas, assim como o Jardim da União, na Zona Sul de São Paulo, que estavam sob ameaça de remoção, ou, ainda, foram removidas (parcial e total) no período de 2017-2019.

O relato da ocupação do Itajaí e da reintegração de posse estão descritos em 2.1. O massacre do ltajaí. Já a história de formação do Jardim da União está dividida em três fases: 2.2. Lona: ocupação criança, 2.3. Madeira: ocupação adolescente e 2.4. Alvenaria: ocupação adulta. Essa divisão se baseia na fala de uma das lideranças da ocupação quando explica:

O8 Para as informações orais, foi mantida a forma coloquial não culta dos depoimentos. E os nomes dos moradores da ocupação Jardim da União aqui citados são fictícios na tentativa de preservá-los e que não sejam prejudicados em alouma medida por terem compartilhado comigo informaç̃es.

109 Hoje se refere ao primeiro semestre de 2021, período de escrita desta disserłação. Ao longo do trabalho a primeira ocupação será referida como "Ocupação do Itajal", já a segunda será mencionada como "Jardim da União". 


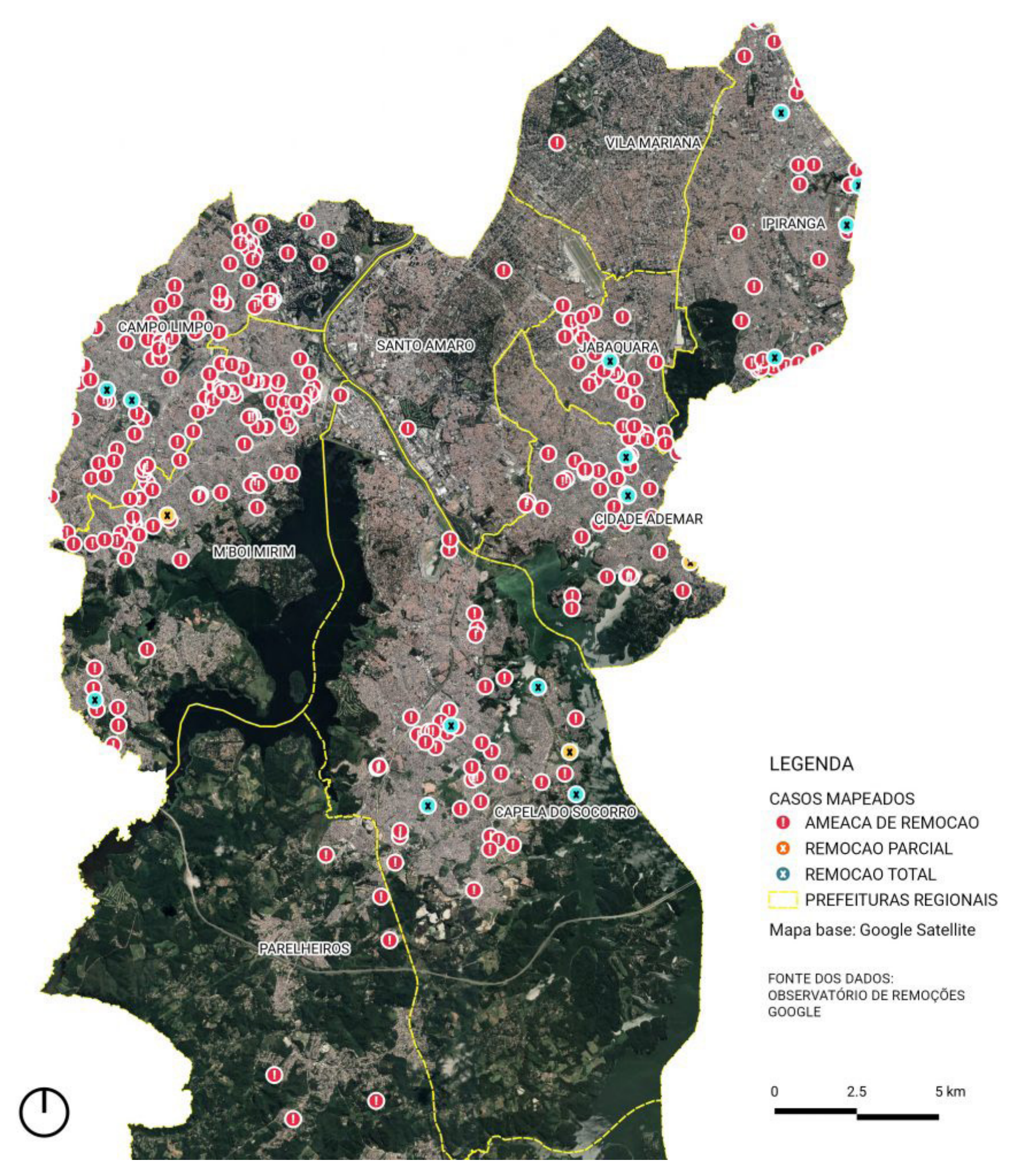

Eu costumo falar o seguinte sobre a ocupação, que ela tem três fases, ou seja, a fase criança é quando se inicia uma ocupação e são feitos barraco de lona, a fase adolescente que mais problemática, né? Que é quando começa a fazer os barracos de madeira. Então, é muito problemático. E tem a fase adulta, que é a fase que nós já tamo fazendo as casas de alvenaria, já tá mais consolidado (Raimundo, CPPATHIS, 2019).

Já no item 2.5. CPPATHIS será relatada a experiência do Curso de Prática Profissionalizante em Assessoria e Assistência Técnica em Habitação de Interesse Social, realizado ao longo do primeiro semestre de 2019 que teve o Jardim da União como território das atividades práticas. Por fim, o item 2.6. Novas dinâmicas: paradoxos do desenvolvimento, retrata as mudanças recentes ocorridas no Jardim da União que impactaram consideravelmente o cotidiano da ocupação e dos seus moradores.

\subsection{O MASSACRE DO ITAJAI}

O desenraizamento é uma condição desagregadora da memória: sua casa é o predomínio das relações de dinheiro sobre outros vínculos sociais. Ter um passado, eis outro direito da pessoa que deriva de seu enraizamento. Entre as famílias mais pobres a mobilidade extrema impede a sedimentação do passado, perde-se a crônica da família e do indivíduo em seu percurso errante. Eis um dos mais cruéis exercícios da opressão econômica sobre o sujeito: a espoliação das lembranças (BOSI, 1994, p. 443).

Os moradores vinculados à Rede de Comunidades Extremo Sul110 ocuparam inicialmente um outro terreno na região do Itajaí, próximo da ocupação atual (Figura 4.5). Essa primeira ocupação foi muito importante pois, para muitos moradores, foi ali que teve início o processo de formação crítica de que eram sujeitos de direito, uma formação política que vai muito além da conquista da casa e passa a se constituir como uma

110 A Rede de Comunidades do Extremo Sul é um movimento popular que atuou de 2010 à 2015 na zona sul de São Paulo e que tinha como proposta, segundo o site do movimento, "a organização autônoma do povo da periferia, sem depender de politiqueiros, nem de patrões, nem da migalha de quem quer que seja. Propomos a união das quebradas e a luta direta como meio de melhorarmos a nossa condição de vida, e combatermos as formas de opressão e de exploração que sofremos todos os dias". Fonte: https://redeextremosul.wordpress.com/o-que-e-a-rede/. Acesso em 01 dez. de 2020. 
experiência coletiva. Muitos moradores relatam que chegaram até a ocupação pela necessidade da casa, mas ao participar da luta social passam a ter noção da espoliação urbana (KOWARICK, 2000) ${ }^{111}$ a qual estão submetidos no dia a dia. Para Fernanda, o Extremo Sul teve um papel fundamental nesse processo, pois as pessoas chegam até o movimento muitas vezes com a experiência de vida e a partir disso vão construindo uma formação política crítica:

Só que a Rede Extremo Sul aqui dentro foi fundamental pra instruir as pessoas. Então, assim, uma galera que não sabia de nada, não tinha conhecimento nenhum sobre sobre os juridiquês, que é necessário numa reunião, sobre a própria organização da ocupação, galera que não sabia nada disso. Tinh prática de vivência, mas não de maneira organizativa, no coletivo, no geral. Então, a rede conseguiu trazer isso pra nossas pessoas, parar, sentar, estudar, anora Par gra, sabe? Então, não tem gado aqui dentro, não tem ninguém que "só vou fazer porque tão mandando". Não, "vou fazer porque é o certo, tem que ser assim". A gente não pode viver em uma sociedade que oprime, que humilha, que exclui, não. Então assim, a galera aqui tem muita consciência disso e é incrivel, incrivel (Fernanda, CPPATHIS, 2019).

Com apoio e formações realizadas pela Rede Extremo Sul, os moradores dessa incipiente ocupação realizaram sucessivos protestos na subprefeitura da Capela do Socorro e procuravam estabelecer um diálogo com a subprefeita da época, Cleide Pandolfi, com o objetivo de negociar a permanência na área. A primeira manifestação que realizaram foi após o recebimento da notificação da reintegração de posse.

Quando nós invadimos Itajaí, foi um dia de sexta-feira, de sexta pra sábado, né? Nós invadimos era meia-noite e quarenta, entramos com multa gente e ali ficamos [...] ate quarta-feira tava tudo muito bem, graças a Deus, não tinha rolado nada.

111 Segundo Kowarick a espoliação urbana "é somatória de extorsões que se opera pela inexistência ou precariedade de serviços de consumo coletivo, que juntamente ao acesso à terra e à moradia apresentam-se como socialmente necessários para a reprodução dos trabalhadores e aguçam ainda mais a dilapidação decorrente da exploração do trabalho ou, o que é pior, da falta desta. Na Grande São Paulo, são inúmeras as manifestações dessa situação espoliativa, que vão desde as longas horas despendidas nos transportes coletivos até a precariedade de vida nas favelas, cortiços ou casas autoconstruidas em terrenos geralmente clandestinos e destituidos de benfeitorias básicas, isto para não falar da inexistência das áreas verdes, da falta de equipamentos culturais e de lazer, da poluição ambiental, da erosão e das ruas não pavimentadas e sem iluminação" (KOWARICK, 2000, p. 22).

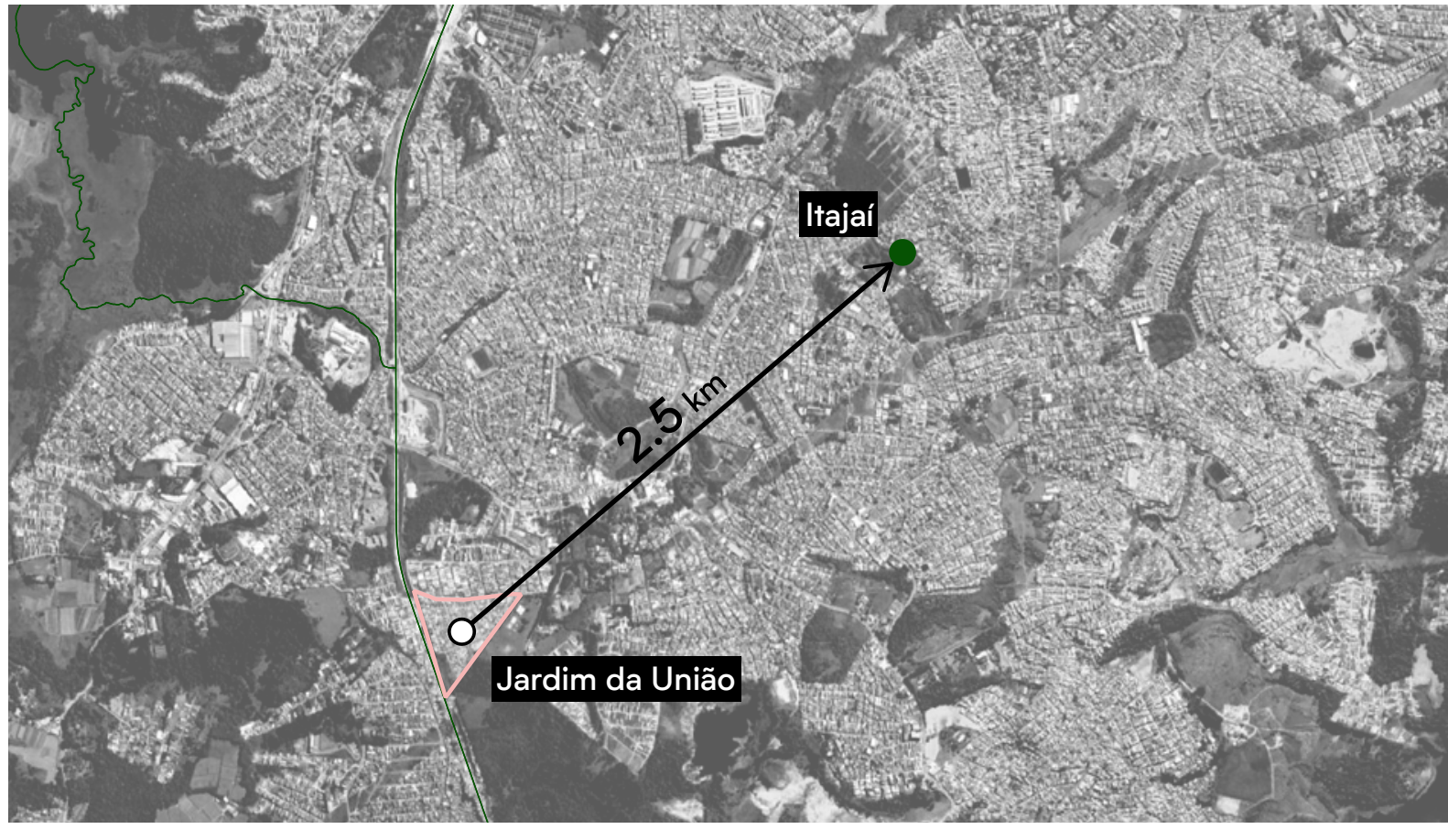

FIGURA 4.5 - Distância aproximada entre o Itajai e o Jardim da União. Elaboração própria.

Aí, né? Como os comentários correm muito, né? Chegou até o ouvido da prefeita da Capela do Socorro. Aí quando chegou mandaram um aviso que a gente tinha que desocupar, porque ali nós não poderia ficar, né? A gente falou: não, mas a gente não quer tomar terra a gente quer uma moradia, mas no tanto não quer po po que a gentén pode pagar, nê Nós, até hoje, è que nós pensa assim: eu roubei, não, nós quer pagar [... Nós quer uma coisa digna, tudo organizadinho, pagar naquilo que a gente pode, né? E foi - que aconteceu. Então nós tava ali e quando menos espera a gente fizemos um protesto muito organizado. Aí a gente foi até a Prefeitura, pra poder falar com a dona, que se não me engano é dona Cleide, o nome dela. Quando nós chegamos ali, um coronel da polícia também tava ali, né? A gente chegamos com a bateria, a gente chegamos assim com aquela força de vontade que a gente tinha dela dizer o "sim" pra gente era muito grande. Então a gente chegar ali por mais que a gente tava cansado de andar com fome, a gente tava muito rouco, porque era um momento assim, que a gente tava com muita sede, né? [...] Era um ajudando o outro, vamo supor se você tivesse um pão, cê me dava um pedaço, eu dava um pedaço pro outro que tava do lado. E o que que aconteceu, né? Aí, a Cleide desceu, né? Primeiro veio o coronel e falou com nós: "ó, a gente vamos trazer a dona Cleide pra conversar com vocês e vocês não vai agredir ela em palavra, né? e nem a gente vai deixar ela agredir vocês, porque eu tô aqui pra defender vocês, mas eu também tô aqui pra defender ela" Aí ela desceu e disse: "oi, pessol, cês querem a resposta?" 
A gente respondeu [empolgado] "sim!!", todo mundo ansioso, né? A resposta foi: “não, a gente não vai deixar vocês ali, não. Eu vou mandar quebrar aquilo ali". Mas a gente falou: "a gente quer um acordo, a gente quer um negócio” la diz: “não, nã quer um acordo. a gente quer um negocio" ela diz: "não, nă tem acordo e nem negocio. Ces pode se a refirar, porque não em mais acordo." Então falamos vamos voltar cada um com nossos barracos. Aí, voltamos, né? Tinha muita gente. Isso fo na terça-feira. Quando foi na quarta ligaram e falou que duas horas da tarde, a gente tem uma reunião marcada dentro do terreno com eles [poder público], né? A gente esperando [na quinta], eles não foi, aí só foi a polícia. A polícia quebrou tudo que nós tinha, tudo, tudo. Assim, os barraco, as pessoas, as criança, né? $\mathrm{O}$ que eles podiam fazer de massacre eles fez. Isso é a primeira vez (Antônia, CPPATHIS, 2019).

Ao trazer o relato da primeira manifestação que realizaram, Antônia fez questão de enfatizar que foi um ato pacífico, "muito organizado", e que por mais que estivessem com fome e cansados estavam ali para ajudar um ao outro, ou seja, enfatiza as práticas solidárias que estão constantemente presentes, já que muitas vezes as dificuldades cotidianas são amenizadas com a reciprocidade e ajuda mútua. Outro ponto que chama atenção no relato é a ênfase que dá à fala do coronel da polícia que estava ali por eles (os manifestantes), mas também para protege a subprefeita, num papel a princípio de mediador, mas que, como visto com uso da força policial na primeira reintegração de posse sofrida, não é neutro, tem lado e não é o da população. Eis uma contradição entre discurso e ação.

Outro ponto que chama atenção na fala dessa moradora, que em certa medida é recorrente em muitos relatos de outros moradores, e revela também uma contradição, é a importância que dá para "queremos pagar pela moradia", afastando nesse sentido a moradia enquanto direito constitucional a ser conquistado. Por mais que estejam inseridos na luta social de reivindicação desse direito, na mentalidade está introjetada a casa - bem essencial à vida - enquanto mercadoria a ser acessada via consumo.

[...] Aí nós juntamos o povo e fez um barracão enorme, "barracão do povo", tinha uma parte que a dona Maria cozinhava. né? E eu trabalhava, ajudava a trazer comida pra aqueles que tava ali. A noite tinha as pessoas que vigiava a noite, né? E tinha também a turma também que vigiava, rondavam durante o dia. Aí quando nós menos esperou, entrou uma viatura, a viatura falou: "vocês pode se a retirar que aqui não vai ficar ninguém. Ai todo mundo falou assim, então vamo todo mundo fazer um barraco, um pertinho do outro, né? E nós fizemos, aí o pessoal assim, tudo os barraquinha ligado com o outro. Aí quando nós pensamos que não, a polícia bateu de novo. Aí chegou e quebrou tudo, chegava assim com as máquina, pegava os barraco Isso á foi a segunda vez (Antôni, CPPATHIS, 2019).

Continuando o relato, Antônia demonstra que após sofrerem o primeiro despejo forçado, os ocupantes se organizaram e decidiram reconstruir a ocupação. Construíram um barracão comunitário, "barracão do povo", onde realizavam as refeições coletivamente e estabeleceram divisão de tarefas: pessoas escaladas para cozinhar, outras para vigiar no período noturno e, quem possuía trabalho, contribuía financeiramente, por exemplo para compra de alimentos que eram compartilhados entre os moradores, já que as refeições eram feitas em conjunto.

A construção bem próxima dos barracos individuais, de maneira que dificultaria a ação dos policiais em caso de despejo, foi a estratégia de resistência acordada entre os moradores contra uma possível reintegração, já que estavam sob ameaça. Outra estratégia era "bater panelas" caso algum policial entrasse na ocupação para avisar os vizinhos e todos ficarem alertas.

[...] No Itajaí nós não dormia. A polícia perseguia a gente como [... No se a gente fosse un bocado de pladrăo, um bocado de bandido. As vezes nós tava deltado e dail a pouco chegava o ronda da noite e batia: "O, a policia tá datrando, entrou na viatura aí", aí a gente ficava alerta. A gente já tinha combinado: quando tiver em perigo, bate uma panela na outra, um barraco no outro, que é pra todo mundo ficar atento, porque dependendo da pessoa a gente pega, mas dependendo, a gente tem que chamar ajuda, reforço né? Então assim, quando o ronda falava que a viatura tá subindo, aí cê só via uma panela batendo no fundo na outra, né? Aí todo mundo já ficava de pé, já acendia as luz. E aí, no outro dia, a gente tinha que trabahar com sono, porque tinha medo

da polícia invadir e matar nós tudo (Antônia, CPPATHIS, 2019).

Ter que "trabalhar com sono" e "medo da polícia matar" demonstram as dificuldades e tensões enfrentadas pelos moradores no início da ocupação, como também a constante insegurança e pressão psicológica a que estavam submetidos. Com pesar na voz, Antônia diz que essas estratégias utilizadas para formação e resistência da ocupação não foram suficientes, fala mais uma vez da força policial, chegando com "máquina" e "quebrando tudo", na segunda reintegração de posse. Mesmo assim não desistiram de continuar tentando a ocupação do Itajaí:

Ai, nós fez de novo, jogamo outro protesto e fizemo outros barracos. Aí, quando nós menos esperamos, eles veio e que- 
brou tudo. Terceira vez. [...] Aí o pessoal pegou e falou assim: "ó, acho que a gente tá quase vencendo. Agora, vamos fazer "Ódo mundo agora faz as suas casas juntinha o cada ai. Na hora que a policia entras, todo mundo vai ficar năo que ná vai derubar em cima das criança, ne?" Aivolta posque não vai derrubar em cima das criança, ne? Aivoltamos lá de novo [protesto na subprefeifura], ai tava o coronel de novo da polícia. Eu ainda peguei o microfone e falei: "Dona Cleide. desce, porque nós só sai daqui depois que a senhora atender nós. Nós não tamos aqui pra poder invadir, nós tamos aqui pra comprar, nós só quer uma autorização da senhora, porque nós somos trabalhador, aqui dentro não tem vagabundo, todo mundo aqui é trabalhador". [...] Aí ela desceu e disse: "ah, cês quer uma resposta? Eu vou dar" Ela disse assim e bateu no peito: "Ouantas vezes vocês invadir o ltajá, eu vou mandar quebrar" [. ] Nós gritamos: "ah nós não vamos sair não

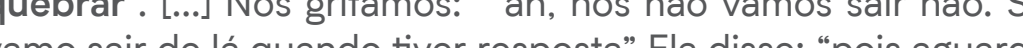
qua que quinta feira vocess vâo ter resposta. E subiu. Mas a gente pensou que ela não ia fazer o que fez. [...] A gente tava feliz achando que ia receber uma vitória muito grande. [...] A gente a receber a resposta e ali ia comemorar, isso era o nosso pensamento (Antônia, CPPATHIS, 2019).

Os moradores organizaram mais algumas manifestações, nas quais a relação diametral entre as figurações de "trabalhador" e "vagabundo/bandido" é constantemente presente. $\mathrm{O}$ argumento "nós somos trabalhadores", é utilizado no sentido de sendo assim (trabalhador) são sujeitos de direito, não estariam invadindo e roubando, mas querendo pagar dentro das suas condições financeiras. A noção da casa enquanto mercadoria mais uma vez aparece nesse trecho, "tamo aqui pra comprar". No horizonte está presente o pensamento liberal de que o "trabalho dignifica o homem".112

Os atos e a argumentação não foram suficientes para conter os despejos, mas mesmo assim chamam a atenção a mobilização dos moradores e a organização de protestos na subprefeitura, ambos frutos dos incentivos e formações dados pela Rede Extremo Sul. ${ }^{113}$ Teresa comenta sobre essas formações:

112 "O trabalho dignifica o homem" concepção construída socialmente para o desenvolvimento do capitalismo, que muitas vezes vela a exploração do trabalhador Como bem coloca Giddens (2005, p. 235): "o trabalho é praticado por aquele que trabalha - o trabalhador - e este nem sempre teve (historicamente) a "dignidade" merecida".

113 Mobilizações incentivadas e organizadas pela Rede Extremo Sul: redeextremosul.wordpress.com/2013/09/23/apoio-as-ocupacoes-do-grajau/ redeextremosul.files.wordpress.com/2013/12/resposta-subprefeifura.pdf redeextremosul.wordpress.com/2013/12/20/basta-de-violencia/
O Extremo Sul treinava a gente, sabe? Nós aprendeu muito com eles. Eles falava: quando chegar os policiais não tem que enfrentar eles, a gente tem que se juntar, ficar todo mundo junto. Então a gente tinha uma corrente, pegava todo mundo um na mão do outro e ficava ali pra receber eles. Então eles treinava a gente tudo direitinho. E assim foi criando força, foi juntando (Teresa, informação verbal, 2020).

Por mais que a essa altura já tivesse ocorrido quatro despejos forçados, os moradores acreditavam que estavam próximos de finalmente conseguir permanecer no terreno. Mesmo que a subprefeita tenha deixado clara a sua posição, ou seja, contrária à permanência da ocupação e uso de força para removê-los ${ }^{114}$, os moradores saíram desse ato esperançosos com a resposta que receberiam nos próximos dias. Inclusive, se organizaram para realizar uma comemoração, uma grande festa, pois acreditavam que "ia receber uma vitória muito grande". Porém:

Quinta feira, depois das seis hora entrou a tropa de choque, aí foi uma quebradeira feia, porque aí não deu tempo, nada. Nada. Chegaram jogando spray de pimenta, bala de borracha. Que assim a gente não conseguia abrir o olho, parece que aquela coisa tava pregando e ardendo, entendeu? E aí, as criança começou a passar mal e a dona Maria enfiava os pano de prato nos baldes pra por nas criança. Aí tinha uma mulher gestante, que correu e caiu. Os outros saiu com ela nos braços. Eu corri pra poder tirar as outras criança que tava dentro de casa e ajudava a pular o muro e eles já chegaram atirando, quebrando, com as máquinas já em cima, [...] jogava fudo nossas coisas dentro daquelas caçamba da Prefeitura. Os armários, fraldas, a comida, os papeis, tudo sabe? Tinha, sabe aquelas máquinas bem grande na frente de pega a terra, eles chegavam assim, pegava tudo, jogava em cima da caçamba. Aí a gente correu pra poder ver se a gente poderia tirar pelo Al a gente corru pra podo menos, um pacote de arroz no barracá, porque tava guardado ali dentro. Mas não deu tempo, já fol caindo, caiu o barracão, geladeira, fogão, tudo. As políias jogando tudo e a gente em cima pra poder salvar as criança. Derrubaram barraco com gente dentro. Muita criança, muita, muita mesmo, criança se machucou. Adulto e idoso também, né? Aquela correria, aquela gritaiada e gente em cima e a polícia batendo. A polícia

14 Contraditoriamente, a subprefeita participou em 2013 (ano da ocupação do Itajail) de uma audiência pública de revisão do Plano de Metas da Prefeitura de São Paulo e considerou muito importante essa primeira consulta popular no território. "O governo tem que vir escutar a população, pois muitas vezes ele não advinha o que o povo deseja, concluiu a subprefeita." Trecho extraído de: www.saopaulo.sp.leg.br/blog/habitacao-e-transporte-sao-prioridades-da-capela-do-socorro/. Acesso em fev.2O21. 
bateu em muita mulher. A polícia bateu em muita criança. A policia bateu em muito adulto. Bateram tanto que parecia as costas de Jesus Cristo Teve gente que quebrou perna, braç, porque caia nos buracos dos barracos. Foi tudo pros praço. porque caia nos buracos dos barracos. Foi "udo pros pronto cerro fiaram que nem um bucado de doido, voando em cima, voan do nas pessoas, pegando o celular e quebrando, entendeu? Fizemos outro protesto. A prefeitura disse batendo no peito: eu disse quantas vezes vocês invadir lá eu mando quebrar (Antônia, CPPATHIS, 2019).

De todas as reintegrações de posse sofridas no ltajaí, essa foi a mais violenta e é ainda memória viva de muitos moradores. ${ }^{115}$ Silva (2O2O, p. 1417) aborda os efeitos traumáticos produzidos nos moradores que sofreram remoção, já que "o ato da remoção violenta transforma os (as) moradores (as) de sujeitos de experiências em objeto da ação de outrem, seja ator público ou privado. Desapossamento. Assujeitamento. Objetificação. Os moradores e moradoras removidos (as) são despojados de sua casa."

Por mais que o fim tenha sido a remoção forçada, ao longo do texto buscou-se demonstrar a resistência da ocupação Itajaí que com intensa mobilização política, a partir do engajamento dos moradores na reivindicação de direitos ainda que atravessados por contradições, foi responsável pela consolidação, para a maior parte das famílias, da primeira experiência coletiva. Mesmo que a motivação inicial dos moradores tenha sido uma demanda individual (a casa), descobriram ao longo do processo um destino comum (SILVA 2020). Esse é o "início" da história da ocupação Jardim da União, constatado inclusive pelas falas dos moradores que estão na ocupação até hoje. Quando perguntados sobre a trajetória da ocupação Jardim da União, é muito comum que iniciem relatando a experiência da remoção do Itajaí que. dada a violência empregada pelo uso da força policial, é chamada de "massacre do Itajai":

[...] Porque a gente tem muita coragem, mas na hora que fal vai matar a gente tem medo né? quem tem coragem de morrer? ninguem ne? e la nós tava ameaçado pela policia e por eles [os políticos]. Nessa quebradeira a gente podia morre também. Mas assim a gente morria lutando. Não assim batendo porrada mais eles, revidando, mas salvando nossas crian-

15 Para mais informações sobre a reintegração de posse da ocupação Jardim Itajal acessar video. Despejo na ocupaçąo Jardim Ilajal, São Paulo. Disoonivel em: www.youtube.com/watch?v=xCGug1Kw-iO. Acesso em 21 ago. 2018. ças. E olha hoje, nossa ocupação cheia de criança e graças a Deus aquelas que conseguiram sobreviver ao massacre do

Dois pontos chamam atenção no resgate do episódio do despejo do Itajaí: os atos e manifestação enquanto organização política popular, que ao sair à rua os moradores buscam meios legítimos de reivindicar seus direitos previstos na Constituição, bem como despejos como esse, com uso da força pelo aparato oficial, demonstram a reação conservadora através da "expressão das forças dominantes na produção do espaço das cidades em toda a história brasileira, que tendem à defesa inquestionável da propriedade privada" (DAL'BÓ DA COSTA, 2019, p. 81).

Como afirma Silva (2020), o ato da remoção forçada quebra a experiência no território ocupado. Experiências significativas, no tempo e no espaço, "que envolvem investimentos pessoais, riscos, expectativas, sofrimentos, apostas e contornamentos na busca de um espaço onde se estabelecer" (SILVA, 2020, p. 1406). A autora mostra que muitas vezes as narrativas dessas pessoas são ocultadas pela grande narrativa da "irregularidade urbana". A isso se soma um efeito ainda mais cruel, já que o estigma de "irregularidade do território" é transpassado para os moradores, no sentido que as pessoas são categorizadas como "moradores irregulares", "removidos", ou ainda, "invasores" e "ilegais".

Sem ignorar as condições árduas e difíceis de uma ocupação, buscou-se reconhecer os vínculos materiais e simbólicos já criados desde o início da ocupação Itajaí. Quem ocupa está em busca do seu lugar no mundo e essa construção se dá a partir das vivências individuais e coletivas, que no caso da remoção forçada do Itajaí foram violentamente interrompidas. Com intuito de trazer luz às narrativas dos moradores dessa primeira ocupação, buscou-se ao máximo relatar esse período a partir de suas falas, já que estes moradores perderam "o direito de ter um passado", em um processo cruel de "espoliação das lembranças" (BOSI, 1994). 
Ocupar era o imperativo de todos eles, ocupar as praças, as ruas, os prédios [terrenos] vazios, povoá-los com seus corpos

ainda firmes, com sua vida incontível. Ocupar era uma

urgência dos corpos, convertida no mais contundente dos

átos políticos, a afrontar a resignação dos serenos. Ocupar,

nem que fosse para estar entre muitos, para existir ainda

uma vez em coletivo.

(Julián Fuks) 


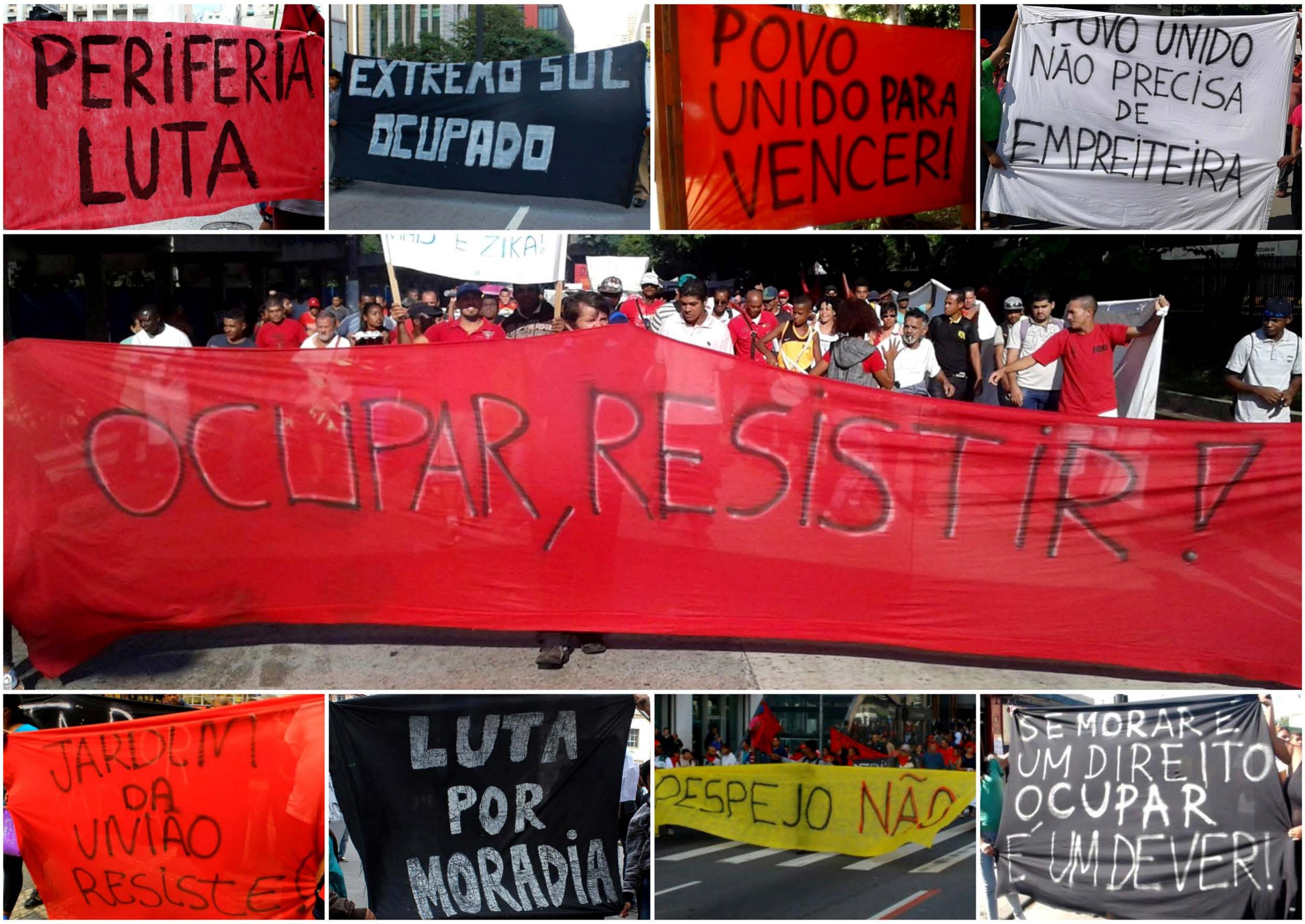




\subsection{LONA: OCUPAÇÃO CRIANÇA}

Noite alta, luar clareando os campos Os pirilampos são estrelas a brilhar Parecem adivinhar quem vem chegando

Semeando vida nova no lugar

Cerca tombada, mundos se desvelam E os que vieram, no cair da madrugada Mãos na enxada, sonhos que se revelam Não esperam a história ser contada

E lonas pretas se espalham a lo largo

No dia claro vem surgindo a ocupação

E o que era nada, no vazio de coisa alguma

Se transforma num verde plantação

(Ocupação - Pedro Munhoz)

Após o quinto despejo sofrido no Itajaí, o mais violento de todos, as famílias juntamente com a Rede Extremo Sul decidiram que não deveriam retornar ao terreno, mas buscar por uma nova área passível de ocupação. Após uma busca pela região, encontraram o terreno onde permanecem até hoje. ${ }^{116} \mathrm{~A}$ nova ocupação foi chamada pelos moradores de Jardim da União. Carlos conta esse início:

A nossa situação foi uma situação muito precária, né? Nós ocupamos o Itajaí e em 2013 nós teve cinco despejo. Dia 12 de outubro de 2013 nós saimo a madrugada do ltajaí, nós viemos pra esse terreno aqui, né? E nós chegamo aqui, não tinh agua, não tinha luz e nós conseguimo uma mangueira de água que o gado bebia aqui dentro tinha um tanque e nos pegava a agua pra fazer comida, pra tomar um banho, dar um banho nas criança e conseguimo um fio de luz, né? Puxamo uma lâmpada pra cozinha, nós tinha uma cozinha comunitária [...]. Algum pessoal dormia na cozinha pra tomar conta dos alimentos, né? Enós ficava fazendo ronda no terreno, enquanto o pessol faE Nós tá lutando (Carlos, CPPATHIS, 2019).

116 Hoje se refere ao primeiro semestre de 2021, periodo final de escrita desta dissertação.
A ocupação do Jardim da União foi realizada no dia 12 de outubro de 2013. Na madrugada de sexta para sábado, um dia estratégico, pois era feriado e os órgãos de justiça estariam fechados e não emitiram um mandado de reintegração de posse. Como demonstra Viana (2020), não sofrer despejo nas primeiras vinte quatro horas de uma ocupação (de terra ou de edifício) é considerado uma vitória para o movimento. Na manhã de sábado a polícia esteve na ocupação perguntando sobre o responsável e é interessante ver a resposta dos moradores:

Então, nós entrou meia-noite e quarenta e cinco. Aí, quando foi às sete horas da manhã, no sábado, a polícia chegou perguntando quem era o responsável, a gente falou que o responsável era nós mesmo, né? E foi embora. Aí quando foi na segunda-feira eles voltaram novamente, olhou, pediu o responsável, a gente falou que não tinha, né? Que a gente que era. Ai eles falou "mas tem o linha de frente" aí a gente falou: "o linha de frente somos nós." A gente junto todo mundo, colocou umas pedras bem grandes na entrada do portão e colocou pros carros não poder entrar. Nós ficava tudo junto aqui dentro (Antônia, CPPATHIS, 2O19).

De fato, a linha de frente era o coletivo. As precariedades e dificuldades provenientes de uma ocupação recente foram enfrentadas com ajuda mútua e solidariedade, como demonstrado na fala de Carlos, "não tinha nada". Em condições mínimas de habitabilidade, os moradores sobreviviam com muito pouco e é justamente o compartilhamento dessas mínimas condições que fez com que partilhassem o esforço da resistência que mantinha e tornava possível habitar aquele espaço (DAL'BÓ DA COSTA, 2019). É no enfrentamento dessas dificuldades cotidianas, das mais simples e imediatas, que os moradores vão construindo uma existência coletiva, bem como demonstrou Sader (1988), de que o sujeito coletivo é constituído a partir das lutas sociais que engendra. Repetidas vezes os moradores contam que no começo era "tudo mato":

A ocupação era um pasto vazio, sem nada, né? Então, a galera se reuniu, não era muita gente, conseguiu se instalar aqui com lona, sem nada, nada, nada, nada, sem um ponto de luz, um ponto de água não tinha nada (Fernanda, CPPATHIS, 2019).

A estratégia utilizada, assim como no Itajaí, foi a construção dos barracos próximos e com maior número de pessoas possíveis na ocupação. Esse adensamento aconteceu de forma espontânea. Josefa conta que do Itajaí vieram por volta de oitenta pes- 
soas, mas na manhã seguinte da ocupação "amanheceu lotado de gente", número que só foi crescendo:

Na primeira semana, não tinha muita gente, mas assim, quando firmou, depois passou uma, duas semanas, que firmou mesmo, isso aqui era lotado, barraco pra todo canto. Acho que já passaram por aqui umas três, quatro mil pessoas, sem brincadeira nenhuma, porque é isso, começo de ocupação a galera fica meio assim, né? Se vai rolar, num vai, passou duas semanas, já foi. Então, assim, era barraco pra tudo que é lado (Fernanda, CPPATHIS, 2019).

Tanto na ocupação do Itajaí, como também do Jardim da União, as famílias não mudaram definitivamente para a ocupação, justamente pela insegurança da permanência. Estabeleceram, portanto, escalas e rodízios de funções e de permanência de um número significativo de moradores na ocupação para conseguirem "barrar" uma possível reintegração de posse. No Itajaí não foi possível, mas no Jardim da União tiveram êxito.

Organizaram coletivamente o território, reservando espaços de uso coletivo, como áreas de lazer para as crianças, os "parquinhos", e uma área para reuniões e assembléias, o "barracão". O barracão, construído através de mutirão dos moradores, de lona, foi local para as reuniões, assembleias e confraternizações da Associação de Moradores Ocupação Jardim da União ${ }^{117}$. Nos primeiros meses da ocupação, o barracão funcionou também como cozinha coletiva, que era gestionada por todos os moradores. Todas as refeições eram feitas em conjunto. É com alegria que uma das moradoras relata esse período:

No início aqui tinha um barracão comunitário onde as mulheres faziam comida, né? E eu tava lá também envolvida, né? [...] O barracão comunitário era bom, era muito gostoso, a gente fem história aqui né? Então era muito bom. Todas as mulheres da ocupação ajudavam, já tinha uma equipe pra isso. Quando a gente tava um pouco cansada, a gente trocava, né? A gente

117 “A Associação de Moradores Ocupação Jardim da União é a entidade que organiza as familias ocupantes promovendo sua integração social, organizando atividades, mantendo os espaços coletivos, além de realizar reuniões permanentes e as assembleias gerais da comunidade, onde se discute e se vota como resolver os problemas do dia-a-dia, como os problemas relacionados à infraestrutura, esporte e lazer. Além disso, é a Associação a responsável pelo cadastro. registro, acompanhamento e representação de fato e legal das familias ocupantes e filiados que mantêm o núcleo urbano o qual se reivindica a regularizaçâo fundiarria, na modalidade legilimação fundiárià (MOVMENTO LUTA POPULAR; ASSOCIAÇAOO OCUPAÇÃO JARDIM DA UNIÄO; PEABIRU-TCA, 2017, p. 12). fazia todas as refeições aqui, as crianças vinha e perguntava: (Lili, CPPATHIS, 2019).

Apesar de ser um período lembrado com alegria, Lili reconhece as dificuldades enfrentadas no início da ocupação:

No início que a gente veio aqui era bem sofrido, sabe? [...]. Era tudo barraquinha de lona. [.... O barracão comunitário também era de lona e quando vinha aqueles ventos, aquelas chuva, aqueles barulhos, sabe? (Lili, CPPATHIS, 2019).

Já Antônia ao relatar esse período da ocupação faz uma analogia com viajantes:

[...] os barracos era tudo de plástico, amarradinho, aí a gente jogava os papelão no chão e dormia, aquele povo tudo ali sabe? parecia um bocado de viajante, mas na verdade era tudo morador (Antônia, CPPATHIS, 2019).

A primeira fase da ocupação, fase criança, se caracterizou com construções em lona a partir de mutirão, improviso dos serviços básicos como água e luz, como também por intensa auto-organização do espaço que constantemente estava em formação e transformação. Nesse primeiro momento de organização, as reuniões dos moradores aconteciam mais de uma vez por semana, para que acordassem as regras que pautariam o cotidiano da ocupação. De acordo com Bastos et. al. (2017), esses espaços comuns, como a cozinha comunitária por exemplo, são importantes para a consolidação da ocupação, já que se trata de um esforço político para reforçar as relações de vizinhança, pautado em valores de cooperação e solidariedade, pois cada um emprega seu tempo livre, muitas vezes horas de descanso, em prol de um objeto coletivo. Para os autores, esses esforços cotidianos produzem uma coesão interna, capaz de tornar os moradores uma coletividade (BASTOS et al., 2017).

Passados os primeiros dois a três meses (último trimestre de 2013) ${ }^{118} \mathrm{sem}$ ordem de despejo, os moradores começaram o processo de mudança permanente para a ocupação. A grande maioria deixou definitivamente de pagar aluguel e passou a morar na ocupação, iniciando assim a segunda fase que se caracterizou, sobretudo, pela construção das moradias individuais.

118 As informações referentes aos periodos da trajetória do Jardim da Uniâo foram coletadas a partir do relato dos moradores e por isso, em alguns casos, há variações nas narrativas. 


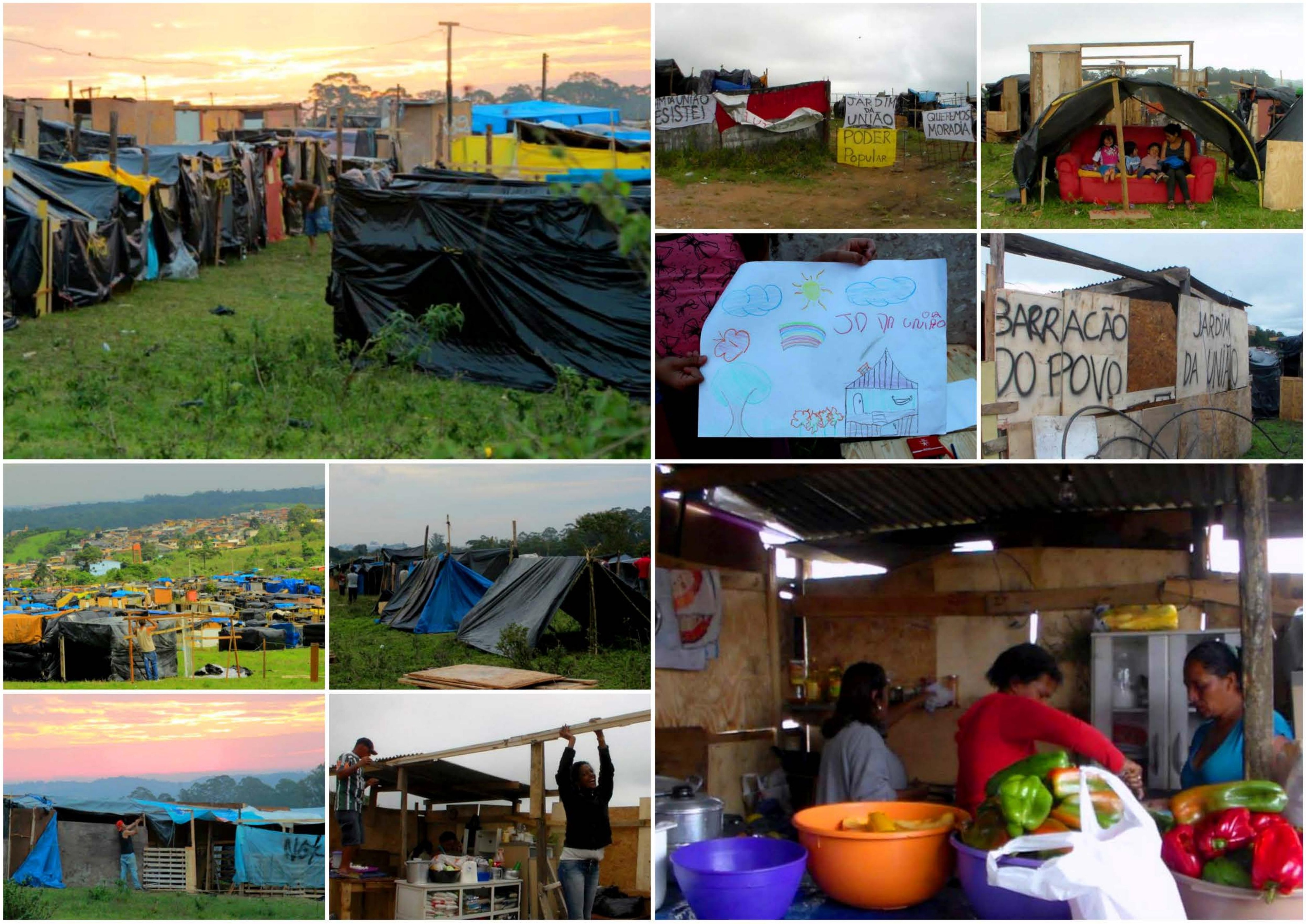




\subsection{MADEIRA: OCUPAÇÃO ADOLESCENTE}

A segunda fase da ocupação se caracterizou pela substituição dos barracos de lona para um material improvisado, geralmente madeirite, pois a insegurança da permanência ainda persistia e, assim, o ideal era investir o mínimo de recursos possível. A orientação dada pela Associação aos moradores era de não construir em alvenaria, já que estavam preocupados com uma possivel reintegração, como aconteceu no Itajaí, o que demonstra o quanto a insegurança da permanência impacta as decisões cotidianas.

A madeira, muitas vezes, foi conseguida por doação ou comprada a prestação em algum depósito da região ou até mesmo trazida do pouco que restou da ocupação do Itajaí. Nesse período ocorreu a individualização das casas, passando cada um a morar com seu núcleo familiar, sendo que cada morado se tornou responsável pela construção da sua moradia. Porém foi comum a prática solidária entre vizinhos, parentes e amigos sem cobrança pelos serviços, em uma força tarefa para ajudar quem estava construindo.

Nessa fase também, o barracão foi reconstruído em madeira, em regime de mutirão, deixando de ser o espaço de cozinha coletiva, uma vez que as refeições passaram a ser feitas nas unidades habitacionais. O novo barracão passou a ser usado para a realização das reuniões, formações e confraternizações.

Em outubro de 2014, um ano após o dia da ocupação, inauguraram a creche chamada de "Filhos da Luta". Importante iniciativa que contribuía para que, sobretudo, as mães solo pudessem trabalhar, enquanto seus filhos ficavam na creche. A creche era mantida através de doações e por uma horta comunitária cultivada pelas moradoras. Organizaram também uma biblioteca e cooperativas de reciclagem e de costura, ainda que em condições difíceis. Fernanda enxerga essa mobilização e auto-organização como fruto da experiência de vida dos moradores:

Conseguimos fazer essa organização junto com a galera que jà é experiente de vida, quando eu falo assim é quem já morou a vida toda em ocupação, morou a vida toda em situação muito precária e sabe se virar, sabe? Mesmo nas condições mais precárias que a ocupação pode oferecer pras pessoas. Então. a galera conseguiu se organizar (Fernanda, CPPATHIS, 2O19).
Essas iniciativas foram importantes para primeiramente organizar a comunidade, solidificando a dimensão coletiva da luta ao consolidar ainda mais a ocupação (que passava da lona para a madeira) e por reforçar a coesão interna, como também serviam de estratégia na luta pela permanência, o que Antônia descreveu como "trazer benefícios" para área:

Aí veio gente também de fora e disse que eles não pode tirar vocês, porque tem benefício, vocês tão produzindo e está vendo que vocês é umas pessoas que vocês merecem isso aqui. Ai pronto, ai eu Al, pronto, al eu saia, conversando com as fábrica de costura, trazia aquele monte de retalho Ai, as mulher ensinava cortar pra fazer fuxico, pra fazer bolsa, né? Ai tinha reciclagem, ninguém tinha coragem de ir pra rua porque tinha vergonha de cata lixo. Falei: "eu não tenho vergonha não, eu vambora" Fui pra rua com as meninas, depois a gente trouxe homem pra poder ajudar na reciclagem. Montemo a creche, aí nós que mantinha a creche, né? Aí assim, cada um dava um pouco, um pouco de arroz, um pouco de feijão. Aí quando o pessoal descobriu, começaram a vim de fora [doação de alimento], davam cesta básica, dava leite pra ajudar as crianças. Essa creche que a gente montou tinha vez que ficava até 50 criança Ai as que a gente monou tinha vez que ficava ate 50 criança. As mães saia pra trabalhar e a gente dava um trocadinho para as educadoras. E eu fazia a horta da creche. Eu plantava cebola, alface, couve, milho, feijão, as verduras pras criança comer (Antônia, CPPATHIS, 2019).

Em um contexto de intenso desemprego, as cooperativas surgiram com o objetivo de fortalecimento financeiro da ocupação, gestionadas de maneira autônoma e horizontal, onde sem hierarquia (moradores recorrentemente falam "sem patrão") cada um recebia em função das horas trabalhadas. Assim, ao mesmo tempo em que fortaleceram a luta coletiva, essas iniciativas contribuíram no âmbito individual, já que propiciavam renda para os moradores, sobretudo para as mulheres. Como relata Antônia, foram elas que encabeçaram as cooperativas de reciclagem e de costura, e ao mesmo tempo poderiam deixar seus filhos na creche enquanto trabalhavam, sem precisar percorrer longas distâncias diariamente.

Apesar da ocupação procurar se consolidar pouco a pouco, a partir da transição das moradias de lona para madeira e com a organização de tais iniciativas, essa fase da ocupação adolescente foi atravessada por diversos conflitos e tensões, como bem Raimundo constatou. Foi nesse período que receberam o primeiro pedido de reintegração de posse e a ocupação passou por diversas alterações.
FIGURA 4.9

4.10 - Ocupação fase da madeira,

organizada a partir de mutirazo, reconstrucão do barracão do "povo" para as "povo" para as desse periodo. E. Espaços comuns: creche "Filhos da Luta", biblioteca, cooperativas de costura e de reciclagem, campo de futebol e horta comunitária. FONTE: Rede Extremo Sul. 


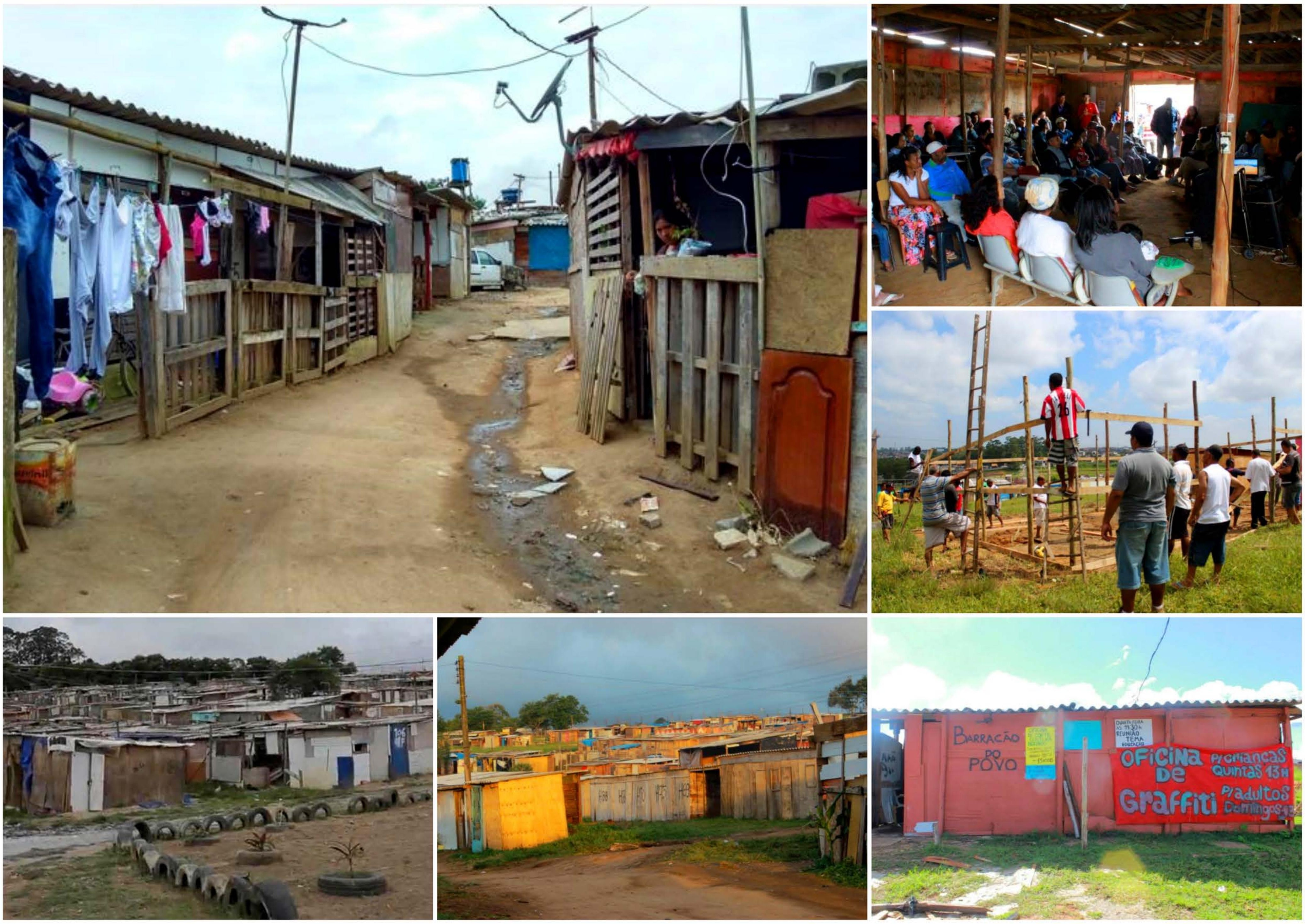




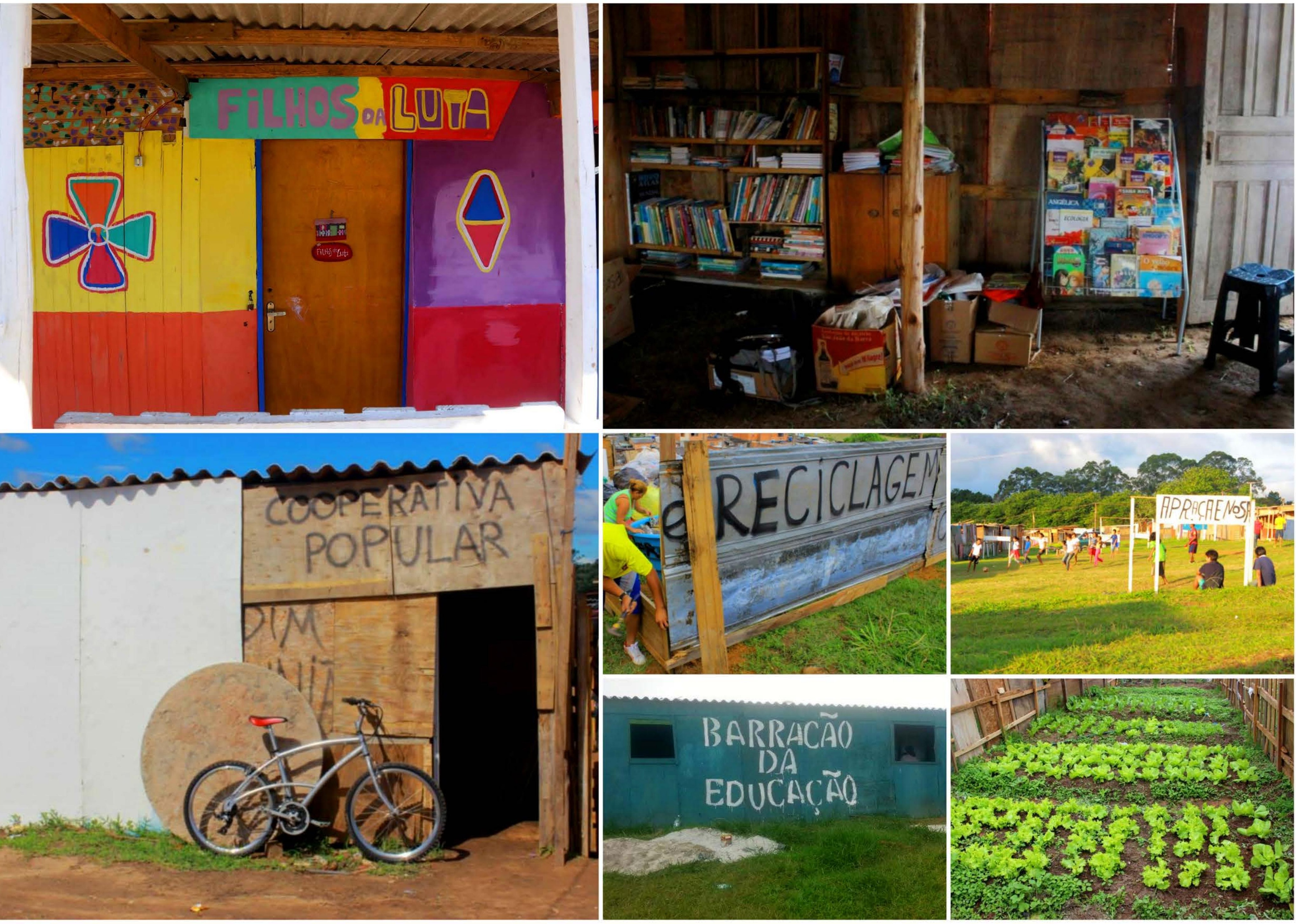




\subsubsection{A LUTA PELA PERMANÊNCIA}

Como o Jardim da União está localizado em um terreno público, desde o início os moradores buscaram consolidar a ocupação, para, além de diminuir as precariedades que dificultavam a vida cotidiana, conseguir negociar a permanência com o poder público.

No começo de 2014, aproximadamente quatro meses depois da formação da ocupação, foi entregue no Jardim da União uma ordem de reintegração de posse, o que fez com que os moradores logo se mobilizassem. No dia que receberam o pedido, se reuniram no barracão e muitos deixaram de comparecer aos trabalhos para ficarem reunidos. Pelos relatos dos moradores, ficaram por volta de três dias, mas nada aconteceu. Então como todos estavam unidos, decidiram que iam reivindicar o direito à permanência junto à $\mathrm{CDHU}$ a partir de um ato organizado.

Organizaram três ônibus com moradores para manifestar no edifício onde ficava a CDHU, localizado no centro de São Paulo, a 35 km da ocupação. Também organizaram um caminhão para levar alguns eletrodomésticos, como fogão e geladeira, já que não sabiam quanto tempo duraria a manifestação, pois intuito era permanecer no edifício da CDHU até a suspensão da reintegração. No final do dia desse ato, os moradores foram comunicados que o pedido de reintegração estava suspenso. Os moradores relatam esse momento com bastante vivacidade:

Nossa, foi muito bom, Foi bom demais. Foi na primeira vez que aqui recebemos a reintegração de posse. Pegamo um caminhão, colocamos geladeira, colocamos fogão, levamos todas as criança e invadimo mesmo, não teve conter, entrou todo mundo e o CDHU ficou pequeno pra gente. $\mathrm{A}$ gente sempre lutou pra ficar aqui. A gente sempre falou que não quer nada de ninguém, quer que regularize pra quente par. Eles fala que não dá que pra aqui já tem pra projeto. Mas que projeto é esse que a gente nun já tem um é esse que a gente nunca vê ( $\mathrm{Te}$ resa, CPPATHIS, 2019).

Na realidade, como constatou Viana (2O2O), a reintegração de posse não era destinada ao Jardim da União, mas a um terreno vizinho. Então não aconteceu a suspensão, mas a afirmação por parte da CDHU de que esse pedido de reintegração não se referia ao Jardim da União.
De qualquer maneira, esse episódio evidencia a potência da mobilização popular. O uso de uma ação direta como a adotada pelos moradores do Jardim da União para pressionar a CDHU é uma forma de protesto que, historicamente, os movimentos sociais adotam (VIANA, 2O2O). Assim, essa interação estado-sociedade demonstra a capacidade de mobilização dos moradores, que passam a expressar suas demandas e pressionam o poder público a negociar (ABERS; SERAFIM; TATAGIBA, 2014).

Ponto importante para a pesquisa, já que traz luz para a política presente nas práticas populares, pois a partir dessa ação direta, que demonstrou a capacidade de mobilização, conseguiram assegurar a permanência (mesmo que sem garantias futuras) e, assim, seguiram consolidando a ocupação. Helena, ao falar do episódio do protesto na CDHU, faz questão de falar da música que é cantada durante as manifestações considerada "grito de guerra" do Jardim da União, cuja letra carrega toda potência da mobilização popular, ao dizer "se o povo soubesse a força que ele tem, não aturava o desaforo de ninguém":

Aqui já teve muitas ordem de despejo, mas a gente venceu. $\mathrm{A}$ gente já invadiu o CDHU, já foi com fogão, entremo e só saímo de lá com a resposta que a gente ia ficar, entendeu? Se for preciso nós invade de novo. Eu sou a dona da música da ocupação, eu que canto nos protestos, nos carros de som (Helena, CPPATHIS, 2019)

A CDHU desde as primeiras negociações alegava que o terreno ocupado pelos moradores era destinado à construção de habitações para atender as famílias já cadastradas pela Companhia, também residentes em área de manancial. Mas esse projeto nunca foi apresentado, como Teresa relatou, e mesmo que se concretizado não seria destinado aos moradores que construíram o Jardim da União.

Então foi proposto por parte da CDHU que a Associação de Moradores se cadastrasse no Ministério das Cidades para conseguir acessar o Programa Minha Casa Minha Vida-Entidades. Assim, poderiam "entrar na fila" e pleitear a construção de um conjunto habitacional em outro terreno. A Rede Extremo Sul considerou que os moradores não foram contemplados por essa proposta e negou essa oferta, pois seus integrantes defendiam a construção autônoma dos moradores, muitas vezes sem estabelecer acordos com o poder público. 


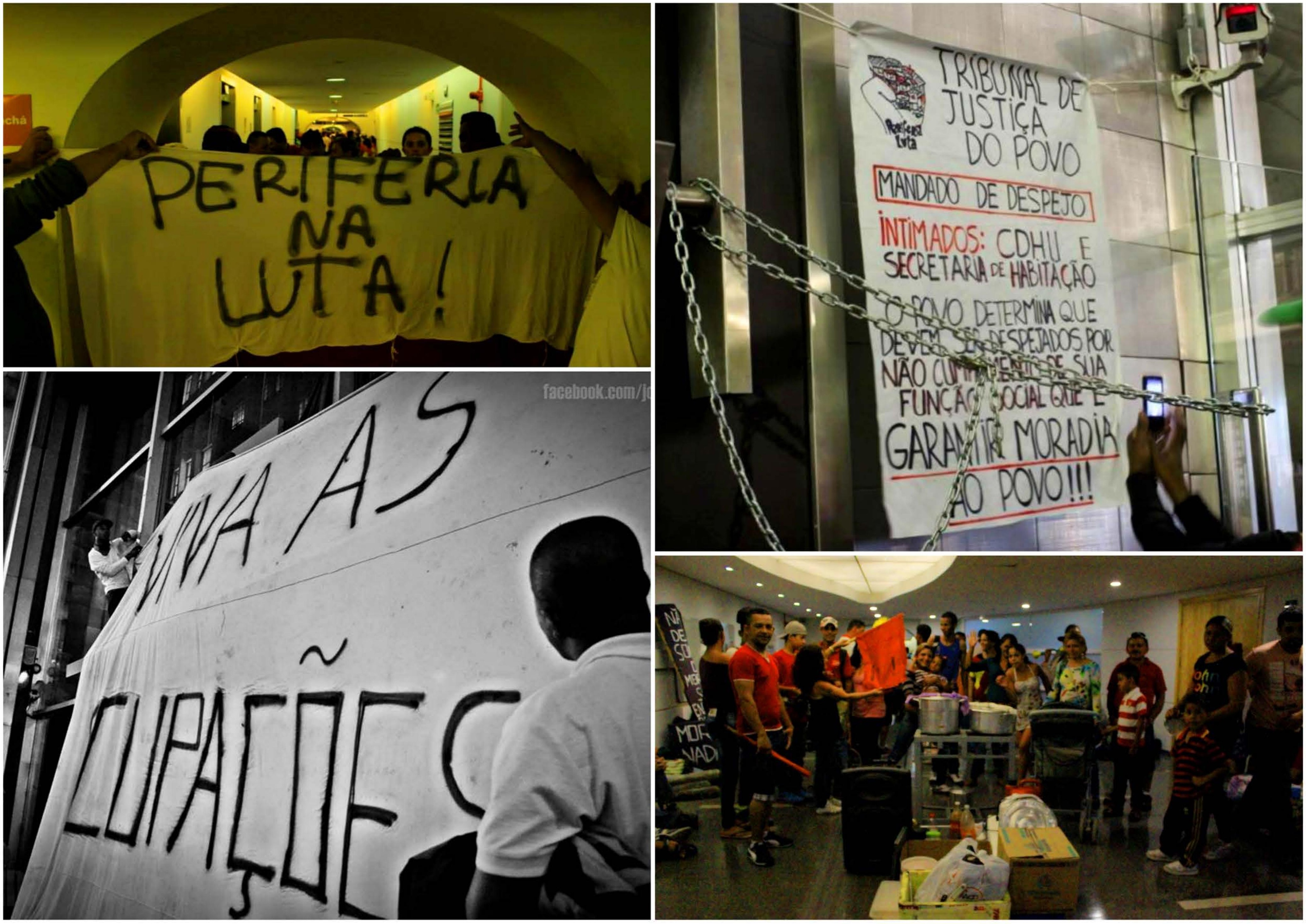


A questão é que a oferta do CDHU foi negada pela Rede sem antes conversar com a Associação, um dos motivos do rompimento com a Rede Extremo Sul. Dessa maneira, sem acordo com a $\mathrm{CDHU}$, a ocupação seguiu sem nenhum tipo de segurança em relação à permanência, o que levou a saída de muitos moradores da ocupação. Esse foi um momento de incertezas para os moradores e até mesmo de uma certa desmobilização, já que não tinham o apoio de um movimento organizado. Fernanda conta que:

Então a Rede Extremo Sul saiu no meio de um despejo, ficou fodo mundo sem saber pra onde ir, o que fazer, onde que gente vai, o que que a gente faz. Então, essa galera que tava mais instruída conseguiu a própria sorte e vamos que vamos, porque isso aqui não pode cair, né? Na primeira assembleia que aconteceu após saída da Rede, foi uma loucura assim, né? Porque ninguém sabia o que fazer, nem sabia pra onde e quem a quente recorre, pra onde que a gente vai. Eu falei, vamos assum a imasonsa do negócio, vamos fazer acontecer. Só que, assim. magina so o sentimento, eu já quero chorar, o sentimento de uma pessoa que a unica coisa que tem, fisicamente falando. sentimentalmente também, é a casa. Aonde você cria toda sua história, cria sua vida, os seus filhos, tudo, tudo, tudo. E tá com ordem de despejo, você vai perder tudo. E não importa se foi trinta, quarenta, cinquenta reais no madeirite, é seu, sabe? $\mathrm{E}$ seu. Então, a galera tava como nunca a flor na pele, sabe? E al, a gente recebeu o convite pra ir no congresso da Conlutas. [.] te, uma força, uma direção (Fernanda, CPPATHIS, 2019).

Com a possibilidade de participar de um congresso organizado pela Coordenação Nacional de Lutas (CONLUTAS), ${ }^{119}$ a Associação decidiu que era um momento oportuno para buscar parceiros e orientação de como proceder na luta. Então, a Associação organizou juntamente aos moradores um financiamento coletivo para viabilizar a ida de uma das lideranças para esse congresso.

Então, ela [liderança] lá encontrou essas pessoas, sabe? As pessoas que acreditam realmente na nossa luta e sabe que é necessário sim, é nosso direito. Então, conseguiu bastante

119 A Coordenação Nacional de lułas foi fundada em 2004 e, segundo o site da organização, "surgiu a partir da unidade de vários setores do movimento sindical na luta contra as reformas neoliberais e iniciou uma primeira experiência de incorporação dos movimentos populares numa mesma entidade. [...] Essa é uma experiência inovadora na organização de nossa classe no Brasil. Busca unir, numa mesma entidade nacional, os movimentos sindicais, populares, da juvenfude e de luta contra a opressão das mulheres, negros, homossexuais e outros segmentos." Disponivel em: http://cspconlutas.org.br/ quem-somos/historia/. Acesso em 10 de maio de 2021. contato, trouxe pra cá e a partir desse momento entra o Movimento Luta Popular que é quem dá todo o suporte pra gente

res, né? (Fernanda, CPPATHIS, 2019).

Assim, a partir desse congresso com o objetivo de fortalecer o processo de luta pela permanência, resistência e mobilização, a Associação passou a ser assessorada pelo Movimento Luta Popular (MLP) ${ }^{120}$ e desde então seguem como parceiros.

Em 2016 receberam uma nova ordem de despejo, que mais uma vez trouxe à tona o argumento de que essa área seria destinada à implantação de um empreendimento habitacional para reassenfamento de famílias incluídas em urbanizações na região do Programa Mananciais (SANTO AMORE; PEREIRA; HORIGOSHI, 2O19).

Entre idas e vindas de negociações que não resultaram em acordos com a CDHU e com intuito de fortalecer a luta pela permanência, os moradores, através do MLP, conheceram a assessoria técnica Peabiru TCA, ${ }^{121}$ que ao longo de 2017 os assessorou no desenvolvimento do Plano Popular Urbanístico Ocupação Jardim da União. Segundo Fernanda, a única maneira de permanecer no Jardim da União era transformando a ocupação em bairro. Ela conta esse processo de decisão entre aguardar na "fila" ou lutar pela permanência com a consolidação da ocupação:

A gente tinha duas alternativas: tinha alternativa de lutar pra ir pra um predinho do projeto Minha Casa, Minha Vida, que a gente sabe que há muito tempo não vinga em mais lugar nenhum [...] que não existe mais pra gente, nossa faixa, que é desempregado e um salário mínimo. Ou a opção de lutar pra ficar. Ou era

um era outro, né? A pessoa vai ou racha, ou a gente entra pra fila

120 Nascido em 2011, o Movimento Luta Popular se define como: "[...] um movimento popular que atua na organização territorial dos trabalhadores e rabalhadoras. Nas quebradas, favelas, bairros e ocupações. Com a juventude da cultura, com a mulherada das comunidades, com as familias sem-teto, nós seguimos realizando fontrindo experiencias de luta dos de baixo porque os de cima já não nos representam." Disponive em: hos de baixo porque os de cina já náo nos representam." Disponivel em: h-revolucionar-as-cidades/481586128701884/. Acesso em 03 fev 2019 .

121 De acordo com o site, a Peabiru Trabalhos Comunitários e Ambientais é uma ONG de Assessoria Técnica fundada em 1993 por um grupo de profissionais (arquitetos e urbanistas, engenheiros, advogados, psicólogos, sociólogos e outros técnicos da área social). A sua missão é contribuir para a universalização do Direito à Cidade e à Moradia Digna, por meio da construção e efetivação de politicas públicas e da assessoria técnica voltada a populações vulneráveis e organizaçoes populares e sociais. Fonte: http://www. peabirutca. org.br/. Acesso em 01 dez. 2020. 
de espera e fica ali na eternidade, ou a gente vai fazer acontecer vai continuar aqui. A gente discutiu entre a gente [Associacão de Moradoresl e depois levou pra assembleia, e por unanimidac decidiu que vamos ficar. Ninguem quer sair daqui. [.... Então, única maneira da gente permanecer aqui era consolidando mais unda o bairo. Ou melhor, transormando num bairro. Aind que a gente chame de ocupação, né? Então, a cara, o formato. já é um bairro (Fernanda, CPPATHIS, 2019).

\subsubsection{PLANO POPULAR: INSTRUMENTO DE LUTA}

Desde o início, o Plano Popular foi entendido como importante instrumento de luta, já que nas negociações com a CDHU os moradores pensaram na urbanização e regularização da ocupação como uma alternativa à remoção das famílias. O objetivo do Plano era a preservação e recuperação ambiental e o desenvolvimento integral dos moradores. Segundo os arquitetos envolvidos o:

(...) 'projeto' tem em si muito menos elementos, muito menos ' execução de obras. Entretanto. em o potencial de cumprir um papel político de organização de resistências pela permanência, de negociações com órgãos públicos e implementação de melhorias concretas das condições de vida (SANTO AMORE; PEREIRA; HORIGOSHI, 2019, p. 185).

Como demonstrado por Viana (2020), pensaram na possibilidade de regularização fundiária frente à ameaça de remoção porque a ocupação Jardim da União se enquadra na lei 13.465 (2017),122 que garante a regularização fundiária de ocupações por parte população de baixa renda e que tenham sido realizadas, desde que comprovado, até dezembro de 2016, através da modalidade de Reurb de Interesse Social (Reurb-S). De acordo com o artigo 10 desta lei os objetivos da Reurb, a serem observados pela União, Estado, Distrito Federal e Municípios, são:

I - identificar os núcleos urbanos informais que devam ser regularizados, organizá-los e assegurar a prestação de serviços

122 De acordo com artigo 14 da lei 13.465 (2017), pode requerer Reurb-S: "[.... os seus beneficiários, individual ou coletivamente, diretamente ou por meio de cooperativas habitacionais, associações de moradores, fundações, organizações sociais, organizações da sociedade civil de interesse público ou outras associações civis que tenham por finalidade atividades nas áreas de desenvolvimento urbano ou regularização fundiária urbana" (LEI No 13.465 DE 11 DE JULHO DE 2017, grifo meu). ções urbanísticas e ambientais em relação à situação de ocupação informal anterior. [...] III - ampliar o acesso à terra urbanizada pela população de baixa renda de modo a priorizar banizada perma po dos ocupon a permanes informais regularizados, [.... VI- garantir o direito social a moradia digna e às condições de vida adequadas; VII - garantir a efetivação da função social da propriedade; VIII - ordenar o pleno desenvolvimento das funções sociais da cidade e garantir o bem-estar de seus habitantes; [...] XI - conceder direitos reais, preferencialmente em nome da mulher; (LEI No 13.465, DE 11 DE JULHO DE 2017).

Como o Jardim da União está localizado em uma Área de Proteção e Recuperação de Mananciais, a APRM-Guarapiranga, o Plano teve como foco apresentar a "melhorias ambientais em relação à situação anterior, comprovadas através de estudos técnicos" (MOVIMENTO LUTA POPULAR; ASSOCIAÇÃO OCUPAÇÃO JARDIM DA UNIÃO; PEABIRU-TCA, 2017, p. 16). E cabendo ao poder público, de acordo com o artigo 37:

Implementar a infraestrutura essencial, os equipamentos comunitários e as melhorias habitacionais previstos nos projetos de regularização, assim como arcar com os ônus de sua manutenção (LEI No 13.465. DE 11 DE JULHO DE 2017).

Importante destacar também que a ocupação da APRM-Guarapiranga deve seguir a lei específica 12.233 (2006), que definiu parâmetros urbanísticos que variam conforme as áreas de intervenção, com objetivo de garantir instalação de infraestrutura de saneamento básico em ocupações, como o Jardim da União, com intuito de recuperação dos mananciais (VIANA, 2O2O).

Contraditoriamente, mesmo estando em APM, a área da ocupação está marcada no Zoneamento Municipal como Zona Especial de Interesse Social (ZEIS-4), como mostra a Figura 4.12. Por isso, para a elaboração do Plano considerou-se a possibilidade de regularização fundiária e jurídica a partir do Plano Diretor Estratégico de São Paulo (PDE-SP) de 2014. ${ }^{23}$

23 O inciso IV do artigo 45 do PDE-SP expõe define que: "[...] áreas caacterizadas por glebas ou lotes não edificados e adequados à urbanização e edificação situadas na Área de Proteção dos Mananciais das bacias hidrográficas dos reservatórios de Guarapiranga e Billings, [...] destinadas à promoção de Habitação de Interesse Social para o atendimento de familias residentes em assentamentos localizados na referida Area de Proteção aos Mananciais, preferencialmente em função de reassentamento resultante de plano de urbanização" (PDE-SP, 2014, p. 59). 
FIGURA 4.12 - Jardim da União delimitado como ZEIS 4.

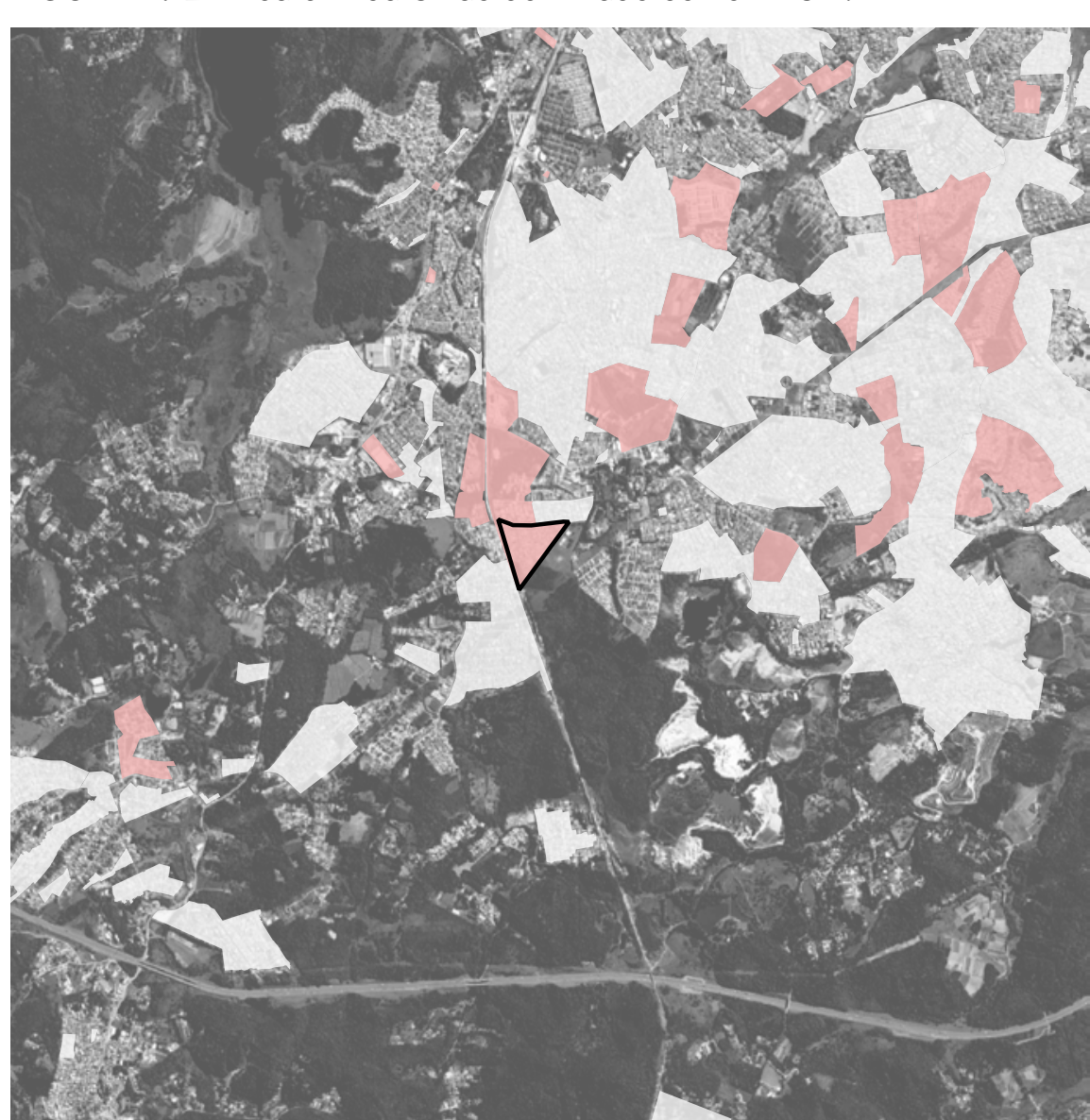

- ZEIS 4

Perimetro Jardim da União

\section{$0 \quad 0.5 \quad 1 \mathrm{~km}$}

FONTE: PDE, 2014 e Lei de Zoneamento, 2016, PMSP
Elaboraçăo Própria.

Assim, amparados pela lei 13.465/2017, pela lei específica da Guarapiranga e pelo PDE-SP, nas reuniões com o poder público, Defensoria Pública, moradores e assessorias tinham a posição de permanência no local, sendo que a elaboração do Plano foi feita com o intuito de auxiliar nesse processo de luta pela regularização fundiária. Em 2017, a Associação de Moradores, em parceria com advogados do MLP, entrou com requerimento para regularização fundiária junto à antiga $\mathrm{CDHU}$ e segue protocolado até o momento à espera de uma resposta de que a área onde se localiza o Jardim da União seja considerada plausível de regularização.

O Plano foi resultado de um longo e complexo processo de visitas dos técnicos da Peabiru guiadas por membros da Associação de Moradores, organização de oficinas comunitárias (Figura 4.13), que foram divididas em duas etapas: a primeira de diagnósticos (espaciais e socioeconômicos), sendo alguns dos resultados apresentados nas Figuras 4.14 e 4.15 e a segunda de projeto, "onde os moradores puderam discutir sobre seus atuais problemas e potencialidades, e pautar as diretrizes do Plano" (MOVIMENTO LUTA POPULAR; ASSOCIAÇÃO OCUPAÇÃO JARDIM DA UNIÃO; PEABIRU-TCA, 2017, p. 12).

Esses encontros não se tratavam de apresentação do projeto aos moradores, mas desde o início de um processo participativo, que envolveu muita escuta, sendo que essa interlocução e troca com os moradores interferia diretamente na concepção e desenvolvimento do projeto. Fernanda conta o processo de construção do plano:

Tava todo mundo muito empolgado pra colocar em prática fudo aquilo que sempre sonhou durante o período que tava no barraco de madeira. [...] Agora, imagina a galera, a ocupação toda, todo mundo falando o que que tá bom, o que não tá, o que que quer, o que que não quer manter. Cara, imagina se todos os bairros fossem feitos assim, pensado por quem mora lá, sabe? Que top que seria isso? Se todo bairro tivesse uma Peabiru da vida, que chega troca ide bairro mor com o morador e fala "cara, o que tá bom pra voce? Como que a gente pode fazer isso aqui melhorar?" Eu acho que esse é o correto, na verdade, né? Mas na verdade, tudo que é feito na periferia é feito por quem não mora na periferia, não entende o que que acontece aqui dentro, não sabe de nada [...]. Porque assim, foi feito por quem não tem a menor ideia do que acontece aqui. Então, a Peabiru trouxe isso pra gente, foi incrível, assim, incrivel. Envolveu as crianças, os adolescentes, os adultos, o pessoal das antigas, gente cansada de vida, de lutar trouxe essa renovacão, motivação (Fernanda, CPPATHIS, 2019).

Como resultado do processo participativo, elaborou-se duas propostas que foram levadas para discussão entre todos os envolvidos. A primeira, Figura 4.16, proposta mantinha praticamente o tecido urbano existente, ou seja, procurava manter a maioria das casas e vias, assim como os moradores haviam construído na "fase da madeira". Isso ocasionava lotes com tamanhos diferentes, alguns sem acesso direto a rua e a permanência das vielas de pedestres, em contrapartida a execução seria menos complexa já que não teriam grandes mudanças. Já a segunda, Figura 4.17, propunha um novo desenho ao tecido urbano, ou seja, uma reconfiguração radical com redesenho das ruas e lotes. Nessa proposta praticamente todos os lotes seriam de $90 \mathrm{~m}^{2}$, dando um aspecto de loteamento (MOVIMENTO LUTA POPULAR; ASSOCIAÇÃO OCUPAÇÃO JARDIM DA UNIÃO; PEABIRU-TCA, 2017). 


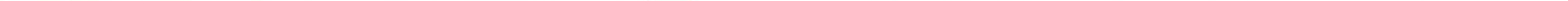




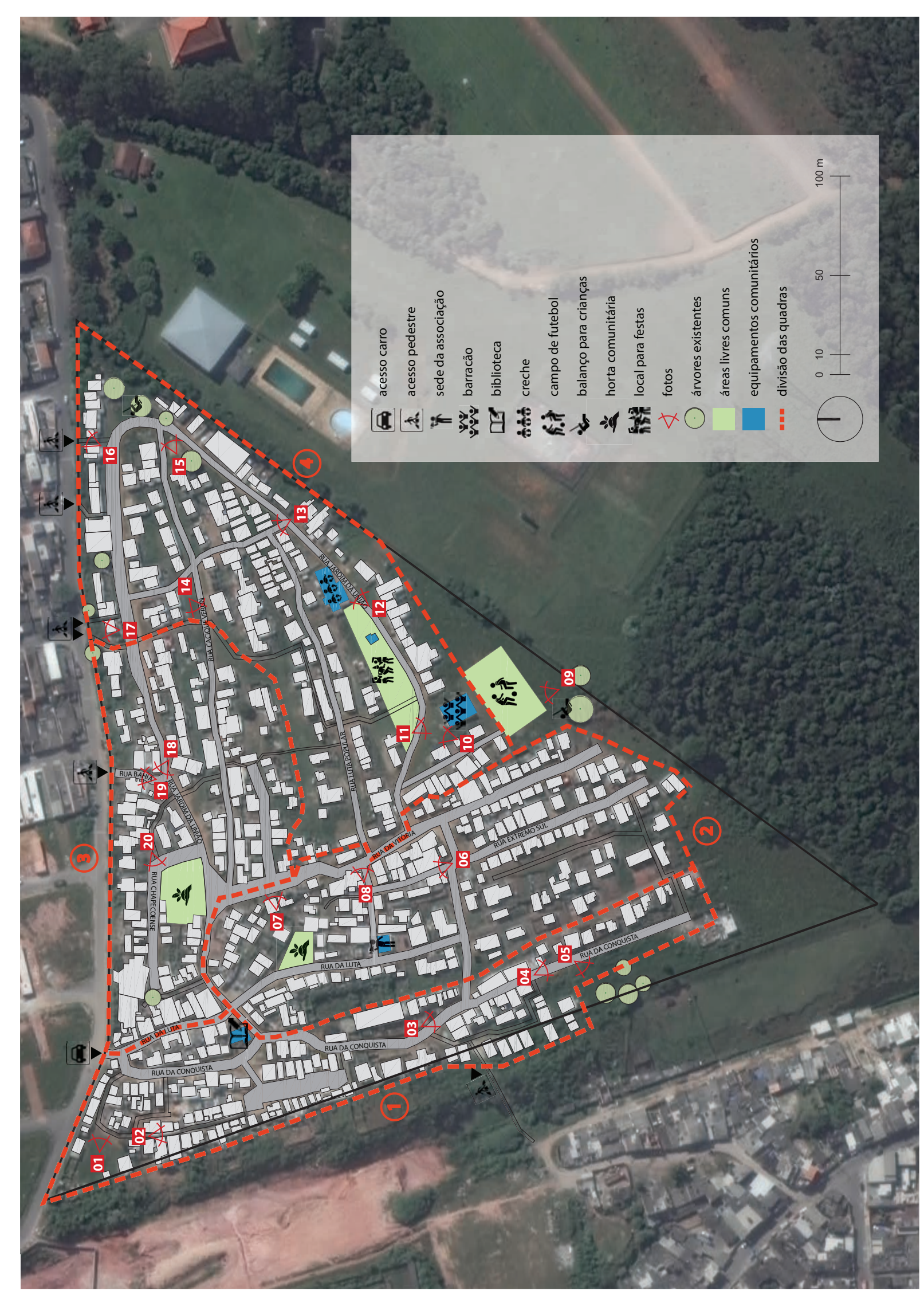

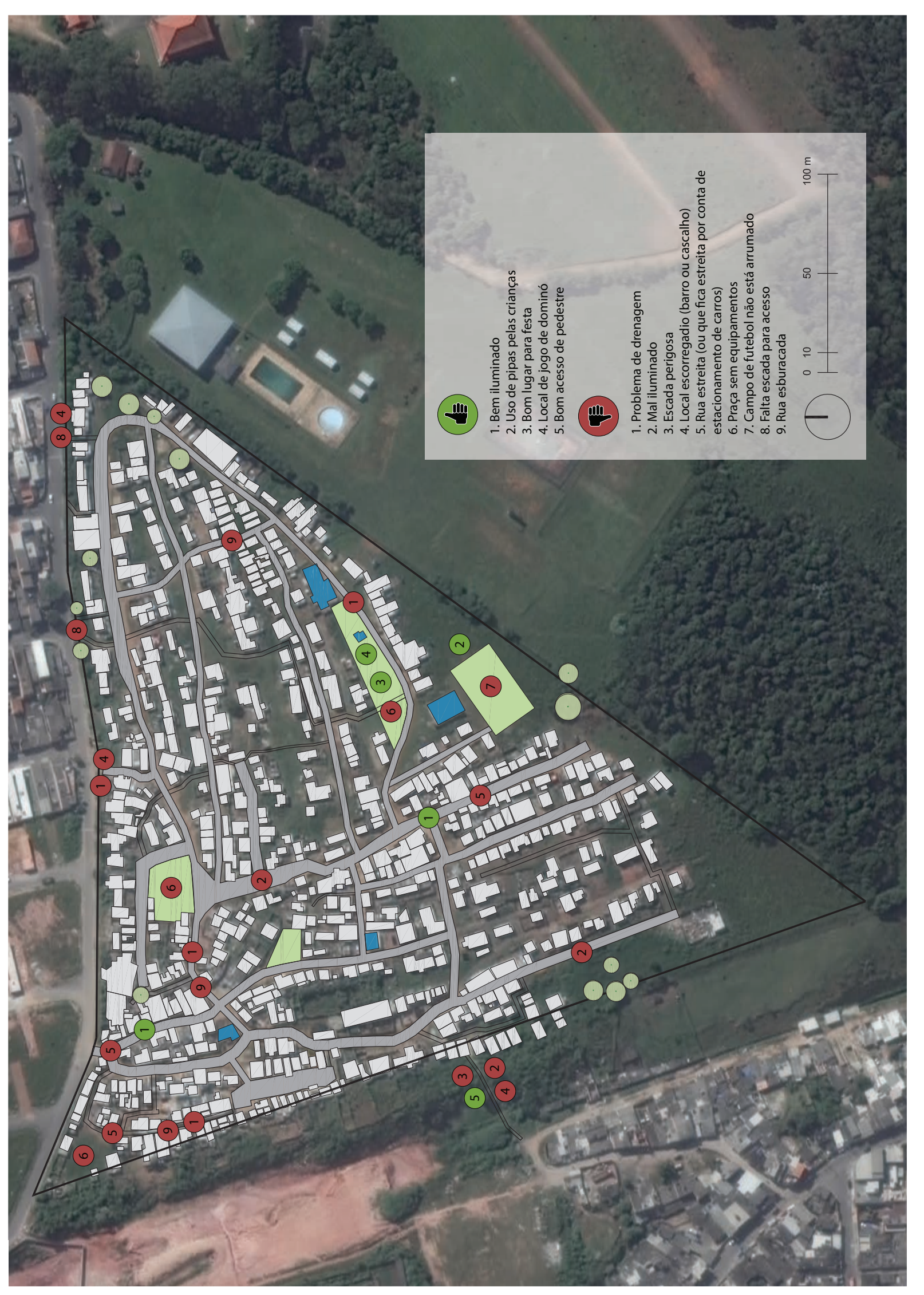


A proposta 2 foi escolhida pela grande maioria dos moradores, praticamente por unanimidade. Um dos principais pontos foi a metragem igual dos lotes, pois para os moradores os lotes irregulares da proposta 1 era um problema e por todos terem acesso a ruas e não a vielas.

Então o primeiro desenho seria não mexer na casa dos moradores, deixar do jeito que tava, mexer o mínimo possível, so que ia ter um problema, ia ter pessoas que ia ficar com 150 $\mathrm{m}^{2}$ e outras com $60 \mathrm{~m}^{2}$, então tinha esse problema. Então optaram de ficar com todos iguais, ou seja, mexer em todos os barracos que tinham, mas desde que ficasse todos metragen guais. Então aí teve que remover mais que $90 \%$ dos barracos de lugar (Raimundo, CPPATHIS, 2O19).

Outro argumento recorrente para a escolha da proposta 2 era que tinha mais "cara de bairro", mesmo que executá-la significasse uma reconfiguração radical da ocupação. Fernanda conta que não esperava que escolhessem essa opção, visto que executar a proposta 1 seria um processo menos complexo e rápido, ela conta:

Depois desse período [de escuta dos moradores], o mais louco de tudo isso, é porque tinha duas opções. Então, foi colocado como opção pros moradores: Gente, cês querem que a gente faça mais próximo ao modelo, a estrutura antiga, ou que a gente faça aquela coisa mais dividido por quadra ua, lote. E foi falado que se a gente fizesse um projeto mais próximo ao formato original da ocupação seria muito mais fácil, muito mais rápido. Agora, se a gente optar pelo projeto de quadra a quadra, seria um processo mais difícil, mais demorado. Então, aí na minha cabeça, quando eu ouvi essa opção, eu pensei "é claro que o pessoal vai escolher essa opcão mais suave" [proposta 1]. Que nada, todo mundo escolheu a outra opção mais top mais cara de bairro, luxo, corque a porque a gente merece. Entao escolheu o projeto quadra quadra, mais estrutur

Mas a proposta 2 apresentada e discutida em relação à proposta 1 não foi a definitiva, sofreu alterações a partir de uma oficina em que os moradores foram divididos em 3 grupos temáticos. O primeiro discutiu sobre o sistema viário, ou seja, o perfil das ruas (largura dos leitos e calçadas), acesso de carros e de pedestres. Como a ocupação está localizada em uma área de proteção aos mananciais, esse grupo trabalhou também com propostas de criação de jardins de chuva e biovaletas integrados à rua como alternativas para aumentar as áreas per- meáveis. ${ }^{124} \mathrm{O}$ segundo grupo refletiu sobre a localização dos equipamentos comunitários e espaços coletivos. Já o terceiro trabalhou na forma de organização dos lotes e nesse sentido houve a interação dos moradores que a proposta 2 "não ia caber todo mundo" (Raimundo, CPPATHIS, 2O19). Ao comparar as Figuras 4.17 e 4.18 percebe-se uma reorganização dos lotes. Isso se deu porque na primeira proposta apresentada os lotes tinham em sua maioria a dimensão de $5 \times 18$ metros, o que resultava numa quantidade menor de lotes, que ao ser revisa-

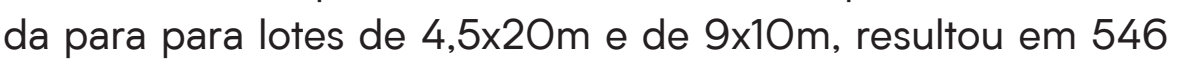
lotes. Naquele momento, na ocupação residiam 530 famílias. Nas palavras dos técnicos da Assessoria:

$\mathrm{Na}$ revisão assumimos dois formatos de lotes de $90 \mathrm{~m} 2$, de $4,5 \times 20 \mathrm{~m}$ e $9 \times 10 \mathrm{~m}$. Os lotes foram implantados paralelos às curvas de nível do terreno. Com isso teremos lotes mais planos, facilitando as construções e minimizando a necessidade nos, facillon de muros de contençáo entre lotes, Desta forma também, facilita o escoamento das águas pluviais e esgoto em direção às ruas. Neste estudo foram consolidados 546 lotes (MOVIMENTO LUTA POPULAR; ASSOCIAÇÃO OCUPAÇÃO JARDIM DA UNIÃO; PEABIRU-TCA, 2017, p. 40).

Portanto, a Figura 4.18 é a versão final do Plano Urbanístico elaborado a partir do processo participativo descrito até aqui. As áreas comuns verdes e de lazer foram previstas no ponto mais alto do terreno, onde já se localizava o campo de futebol. A ideia foi que essas áreas contribuíssem para retenção da água da chuva, correndo menor quantidade de água para os pontos mais baixos do terreno. O plantio de árvores junto à mata existente também foi uma diretriz bastante discutida, a fim de contribuir para a permanência dessa. Já que a ocupação se encontra em APM, a permeabilidade do solo e a ampliação de áreas verdes são pontos muito importantes.

24 "Os jardins de chuva utilizam a atividade biológica de plantas e microorganismos para remover os poluentes das águas pluviais, e contribui para a infiltração e retenção dos volumes das águas das chuvas. Os fluxos de água se acumulam nesses jardins formando pequenas poças, e, gradualmente, a água é infiltrada no solo. Os poluentes são removidos por absorção, filtração, volatilização, troca de ions e decomposição. A água limpa pode ser infiltrada no terreno para recarga do lençol freático. [...] Outra possibilidade considerada no plano de urbanização para aumentar a permeabilidade e diminuição da velocidade de escoamento das águas de chuva da Ocupação Jardim da União são as biovaletas. Elas são canais lineares com plantas, e podem funcionar muito bem com os jardins de chuva" (MOVIMENTO LUTA POPULAR; ASSOCIAÇÃO OCUPAÇÃO JARDIM DA UNIÃO; PEABIRU-TCA, 2017, p. 41). 
FIGURA 4.16 E 4.17 - Acima, Proposta 1, na qual foi mantido o tecido urbano existente. Abaixo, Proposta 2, reconfiguração dos lotes e ruas.
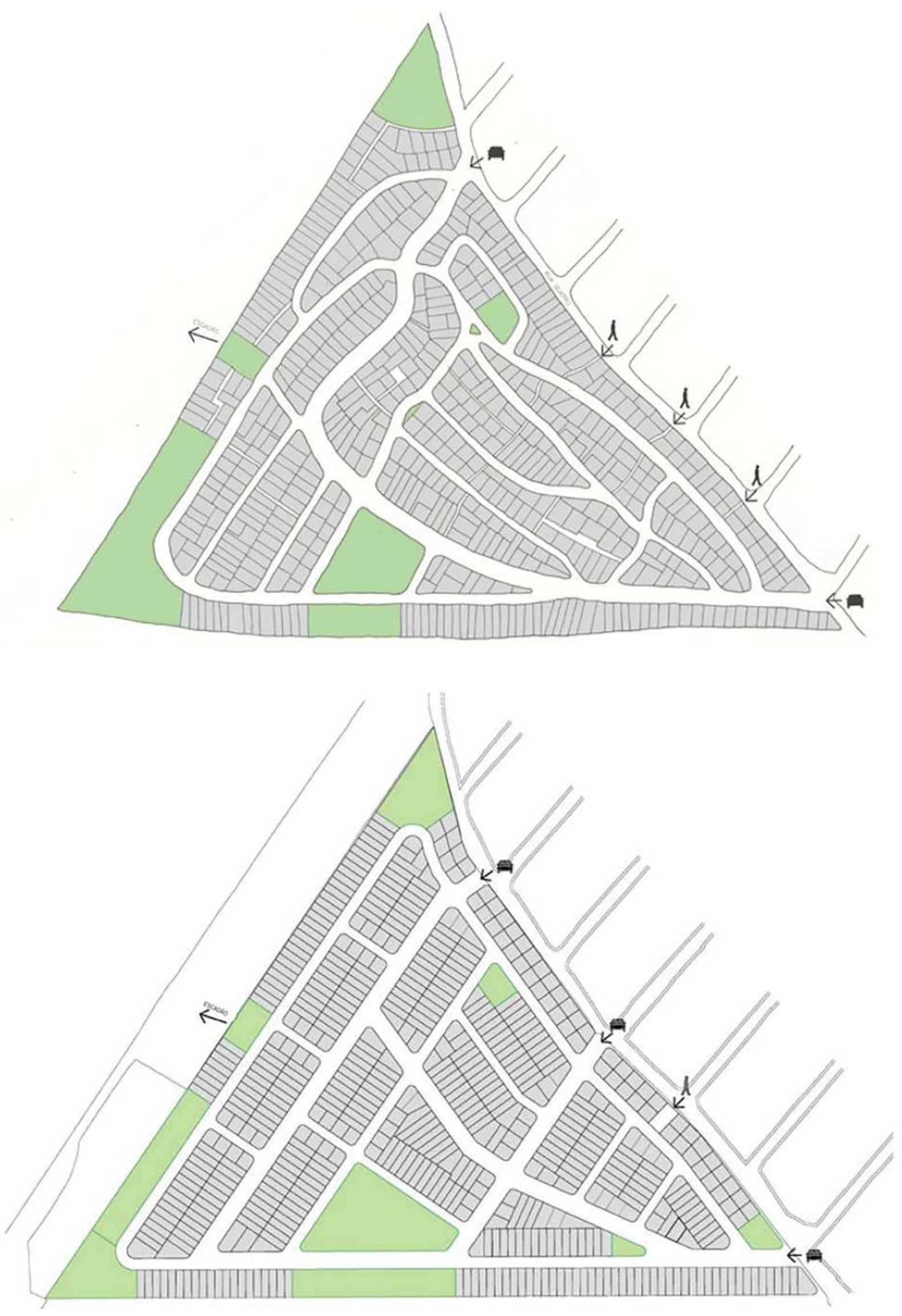

FIGURA 4.18 - Versão final do Plano Popular Urbanístico

Ocupação Jardim da União.
FONTE: Acervo Peabiru TCA (2017)

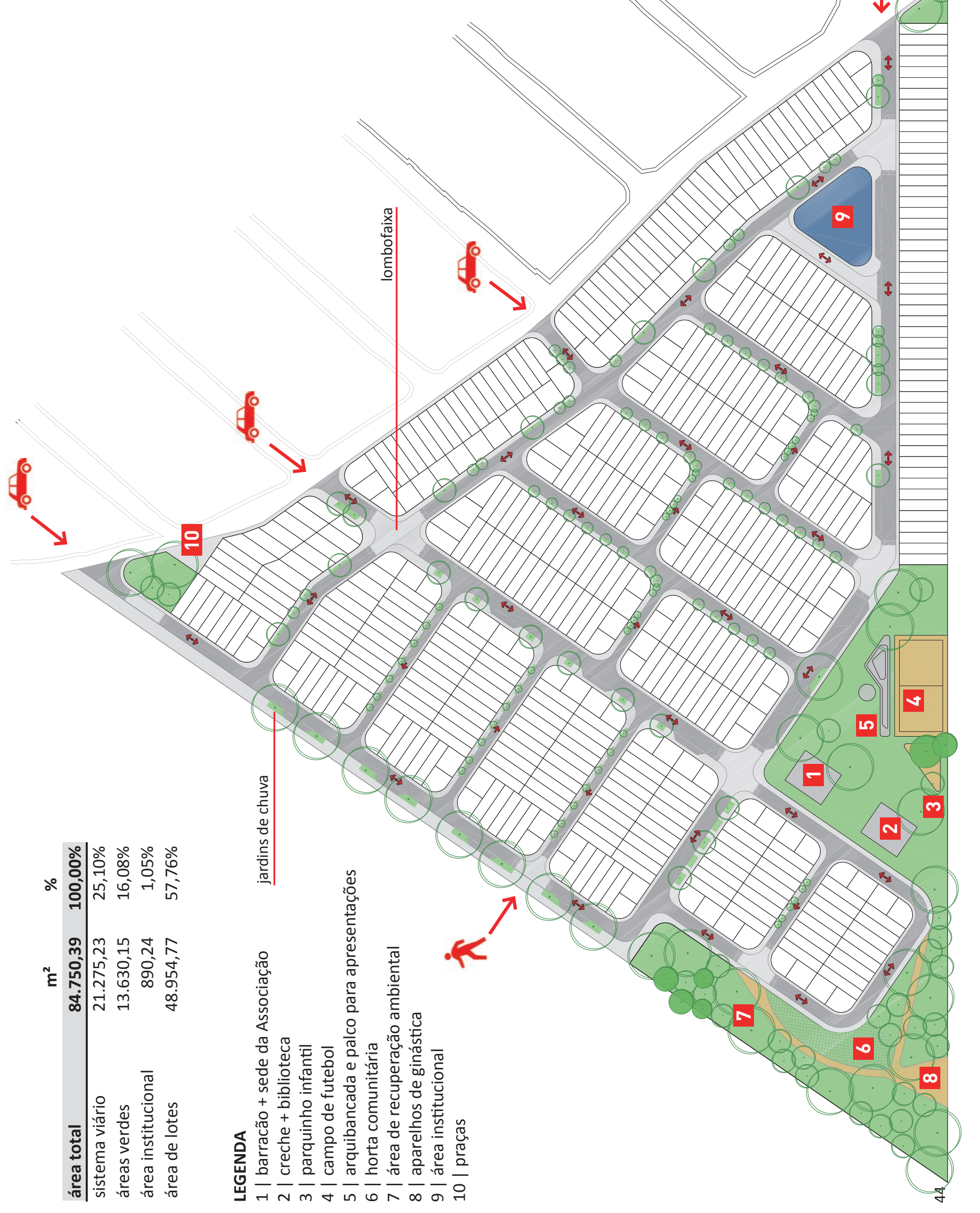


Como mostra a Figura 4.18, junto a essas áreas comuns verdes, foi reservado um espaço para a construção de um novo barracão, para realização de reuniões e festas, e que também serviria de sede para a Associação (1), espaços para creche e biblioteca (2), áreas livres de lazer como: parquinho infantil (3), campo de futebol (4), que foi mantido no mesmo local , arquibancada e palco de apresentações (5), horta comunitária (6), prática já existente na ocupação, aparelhos de ginástica (8). Próxima a uma das entradas do terreno, foi prevista uma área instituciona (9), com $890 \mathrm{~m}^{2}$ para implantação de um equipamento público, que poderia ser por exemplo creche, escola ou Unidade Básica de Saúde (UBS). Algumas pequenas praças também foram previstas (10), próximas às ruas de acesso à ocupação. Essas praças foram pensadas como áreas de estar e lazer, como também poderiam abrigar pontos de peruas escolares e ônibus.

\subsection{TIJOLO: OCUPAÇÃO ADULTA}

A elaboração e execução do plano teve como horizonte o fortalecimento da luta que os moradores do Jardim da União estavam enfrentando pela permanência após receberem pedidos de reintegração de posse, o que Fernanda descreveu como "fo preciso organizar para urbanizar". Mas, para além desse objetivo coletivo, existia também o sentido de melhorar as condições de habitabilidade, visto que desde o início da ocupação, em 2013, os moradores estavam vivendo em condições muitas vezes precárias e insalubres em suas moradias de madeira, 0 que se agravava com o passar dos anos.

Então a gente decidiu fazer a urbanização e não só por essa questão de se tornar um bairro. Mas assim, cara, pensa viver cinco anos em um barraco de madeira. Gente, é surreal, assim, sabe? Agora tá frio, né? Então, imagina, tá num barraco de madeira e assim, a madeira não veda nada, ela só tá al passa tudo, passa frio, geada, chuva. E um cheiro constante de mofo. Então, a galera que construiu em 2013, tava com barraco de pé até 2017, 2018. Então, assim, era insuportáve pra todo mundo. Galera tava cansada, não aguentava mais. insalubre, sabe? $\mathrm{E}$ insalubre, você deixar as pessoas viverem ssim. Então, os barracos tavam muito deteriorados (Fernanda, CPPATHIS, 2019).

Além das condições de moradia, a questão do esgoto até aquele momento também ainda era uma preocupação tanto para os moradores quanto para a assessoria. Já que esse terreno não estava conectado a uma rede coletora, o esgoto era coletado através de fossas negras. Para além de ser um grave problema ambiental, considerando a quantidade de famílias (530) e a proximidade com os mananciais, era um problema de saúde para os moradores, por conta da contaminação do solo, do mau cheiro e da presença de ratos e cobras. Durante a elaboração do Plano essa questão foi bastante discutida e pensou-se em soluções alternativas de coleta e tratamento de esgoto, como por exemplo Tanque de Evapo-Transpiração (TEVAP) e o Círculo de Bananeiras, ${ }^{125}$ consideradas prioridades no processo de urbanização (MOVIMENTO LUTA POPULAR; ASSOCIAÇÃO OCUPAÇÃO JARDIM DA UNIÃO; PEABIRU-TCA, 2017).

Assim, na ausência do cumprimento das obrigações do Estado, com o Plano Urbanístico em mãos e com recursos próprios, os moradores começaram o processo de execução do Plano a partir de esforços coletivos e individuais. Como afirma Maricato (1982), a autoconstrução não se restringe à produção do edifício-casa, mas também se refere à construção de equipamentos comunitários e infraestruturas, caracterizando assim o que poderia se chamar de "autourbanização".

Esse ponto merece destaque pelo impressionante processo autogestionário à medida que os próprios moradores viabilizaram e executaram o Plano, com trabalho próprio não remunerado e trabalho remunerado informal, muitas vezes no tempo da urgência. Essa é uma especificidade dessa ocupação, pois executaram Plano, sem que esse possuísse informações suficientes (não se tratava de um projeto executivo), e sem assessoramento técnico. A Peabiru não participou desse momento de execução, inclusive foi um "susto" para os técnicos quando voltaram na área depois de um tempo e puderam constatar muito do Plano havia sido executado. Um dos arquitetos relata que na concepção da Assessoria, o Plano foi feito para "negociar", mas para os moradores era também para "executar". Fernanda conta esse processo:

Depois que foi decidido tudo isso, todo esse processo, aí sim iniciou a parte física das mudanças. Pesquisar como fazer, estudar, porque até então a gente só tinha o projeto em mãos e por uma questão financeira a gente decidiu que nesse mo-

125 Para ver mais sobre essas duas soluções propostas alternativas à fossa negra, ver Cartilha Grupo Práxis disponivel em: dialogoselianasilva.wordpress.com/2013/07/10/ cartihas-circulo-de-bananeiras-e-tevap/. Acesso em jan. de 202. 
mento a Peabiru não atuasse pra fazer as coisas. Mas eles deram uma orientacão do que a gente precisava fazer porque se não fosse isso não sei o que a gente ia fazer ia ser um processo muito mais dificil muito mais demorado. A gente ia pesquisar multo mais difli, mulo mais demorado. A gente ia presquisar no yourube: "como fazer un bairo", sei lá, qualquer colsa do ipo. Porque se não tivesse esse suporte, não ia rolar mesmo. Então a gente começou a pesquisar como a gente ia fazer opografia, o planialtimétrico da ocupação. Fomos pesquisa um topógrafo. Caríssimo, sem condições. Então começamo conversar com um com outro morador. Então a gente descobriu que tinha um cara aqui dentro que tinha feito curso de fopografia. Aonde você imagina uma coisa dessa? E aí o cara olha pra mim e fala que aqui dentro só tem vagabundo? Não é pra meter o loco? (Fernanda, CPPATHIS, 2019).

Sem saber ao certo como executar o Plano, os moradores buscaram orientação e organizaram inúmeras conversas entre eles. Contam que foram diversas reuniões e assembleias, muitas vezes mais de duas por semana. Sem dúvida, essa mobilização popular e a densidade política presentes nessa ocupação, ou seja, a capacidade de auto-organização desde o início, contribuíram de forma incisiva para conseguirem executar o Plano.

A orientação que receberam da Peabiru foi de iniciar pela área menos densa, onde existisse menos barracos, já que assim teriam mais facilidade para marcar os lotes definitivos $e$ iniciar o processo de mudança dos moradores. Acreditavam que no início dessa reconfiguração iriam precisar construi moradias provisórias, ou seja, algumas casas para que as famílias pudessem mudar até conseguir construir sua casa no lote definitivo. Mas essas moradias provisórias não foram necessárias, pois os moradores conseguiram se organizar "individualmente" (sem necessitar do apoio da Associação) para a mudança de lote.

Em geral, quando a Associação entregava o lote marcado para o morador, este já realizava sua mudança direto para o lote "certo". Processo relativamente rápido, já que as moradias eram de madeira. Um dos membros da Associação que acompanhou de perto esse processo conta que:

eles mesmo se organizaram sozinho e não precisou nada disso [moradia provisória], isso a gente tava pensando que era um problema, ia causar problemas para derrubar o barraco, para fazer mudança, e meio que isso foi tão simples, natural. Não foi necessário barracos provisórios para alojar as famílias (Raimundo, CPPATHIS, 2019).
Helena, uma senhora de aproximadamente 70 anos, é um exemplo de como se deu essa mudança de maneira rápida e menos complexa do que se previa inicialmente:

Tem muita gente que se acomoda, não tira seu barraco do lugar para abrir a rua. Tem que tirar. Quando ela [uma das lideranças] falou para mim: "Dona Helona, seu barraco vai mudar pra qus] feu lote é esse" quando me entegou meu lote no outro dia, seu ló é écu eu já comecei derubar o balai e trazer pra ca. Eu trouxe de madeira prá cá, porque na hora eu não podia comprar bloco pra fazer, né? Trouxe de madeira, depois eu fui comprando os bloco e fui fazendo. Mas tem que derrubar. Cada um tem que firar os barraco da rua, pra abrir a rua pra sabesp entrar, porque se não empata nós também, né? (Helena, CPPATHIS, 2019).

Mas, apesar de ter sido mais "simples" do que se previa, isso não foi unanimidade. Alguns poucos moradores, cerca de $10 \%$, demoraram mais para conseguir realizar a mudança para o lote definitivo. Quando isso acontecia, os moradores se reuniam e iam conversar para entender o motivo do atraso, às vezes necessitando de mais de uma conversa. Em geral se tratava de falta de recursos financeiros, mas também de "acomodação". Quando isso acontecia a Associação utilizava como argumento de convencimento a necessidade de organização da ocupação para contribuir nas negociações junto ao poder público e, como Helena disse, para possivel instalação futura de infraestrutura.

Montaram equipes de trabalho que, em geral, eram formadas pelo topógrafo (morador da ocupação), três assistentes (moradores também) e algum membro da Associação de Moradores. Dessa equipe, a única mão de obra remunerada foi o topógrafo, pago através de arrecadação coletiva. A Associação ficou responsável por organizar para qual lote o morador gostaria de mudar e, para isso, fizeram uma pesquisa com os moradores perguntando se preferiam ficar próximo da área que estavam ou migrar para algum outro ponto da ocupação. Em geral, preferiram ficar na mesma área e principalmente próximo dos mesmos vizinhos, o que fez com que as mudanças ocorressem por "blocos de vizinhança".

Para organização das famílias e numeração das casas, a Associação já dividia a ocupação em quatro quadras (Figura 4.14). Foi a partir dessa divisão que se organizaram para iniciar o processo de auto-urbanização. Como cada quadra tinha um grau de adensamento diferente, sendo a 1 mais densa e 4 a menos densa, iniciaram pela quadra 4. Apesar de seguir essa lógica 
do adensamento, a intervenção foi sendo realizada de maneira não linear, não contínua, no "vai e volta" como relatam os moradores, pois seguiam à medida que conseguiam desocupar os lotes e realocar os moradores e não a sequência de numeração das novas quadras.

Dessa maneira, seguindo a orientação de iniciar pela área mais vazia, iniciaram a "topografia" pela quadra 4, sendo a Rua da União a primeira a ser aberta, e a quadra 17 a primeira a ser marcada os lotes (Figura 4.19). Chamam de "topografia" o processo de delimitação dos lotes e ruas a partir do previsto no Plano Urbanístico. Muitas vezes, a máquina retroescavadeira só "acertava" a rua semanas depois. Muitas ruas, sobretudo as transversais, foram abertas em regime de mutirão com ferramentas manuais, sem envolvimento direto da Associação de Moradores, partindo da organização dos próprios moradores e do representante de quadra. ${ }^{126}$ Foi o que aconteceu, por exemplo, com as quadras de 1 a 7 , área mais adensada antes da execução do plano (área 1 e 2 da Figura 4.14). Essa área foi a última a iniciar a "topografia", mas as primeiras quadras a mudarem por completo as casas. A Associação abriu a Rua Vitória com a máquina e o restante foi por iniciativa dos moradores, o que fo uma surpresa para os membros da Associação:

Mas uma coisa interessante aqui por ser a última foi as primeiras a abrir as ruas a mudar $100 \%$ os barracos de lugares, foi muito interessante, porque nós ficava às vezes mais centrado nessa parte aqui [área 3 e 4 da Figura 4.14] e quando nós fomos dar uma volta na ocupação essas ruas e quadras já estavam praticamente prontas. Nós nem sabia. Eles se meXerav sozinhos, juntaram os moradores pra fazer abertura de xera foi rua, foi $100 \%$ os moram os moradores pra fazer abs sem intervenção da Associação. Isso foi multo interessante. As ruas transversais o representante de quadra conversava com os moradores e eles que fazer a abertura dessas ruas, no braço (Raimundo, CPPATHIS, 2019).

Foi nessa área também que teve início o processo de construção das casas em alvenaria. Isso demonstra que quanto mais se afasta a insegurança de uma possível remoção, a relação entre os moradores e o espaço do Jardim da União vai se alterando, de maneira que a possibilidade de permanência vai fazendo com que se sintam mais seguros para realizar melhorias em suas casas.

126 Os representantes de quadra são moradores que fazem a mediação entre a Associação e os demais moradores da respectiva quadra que representa.

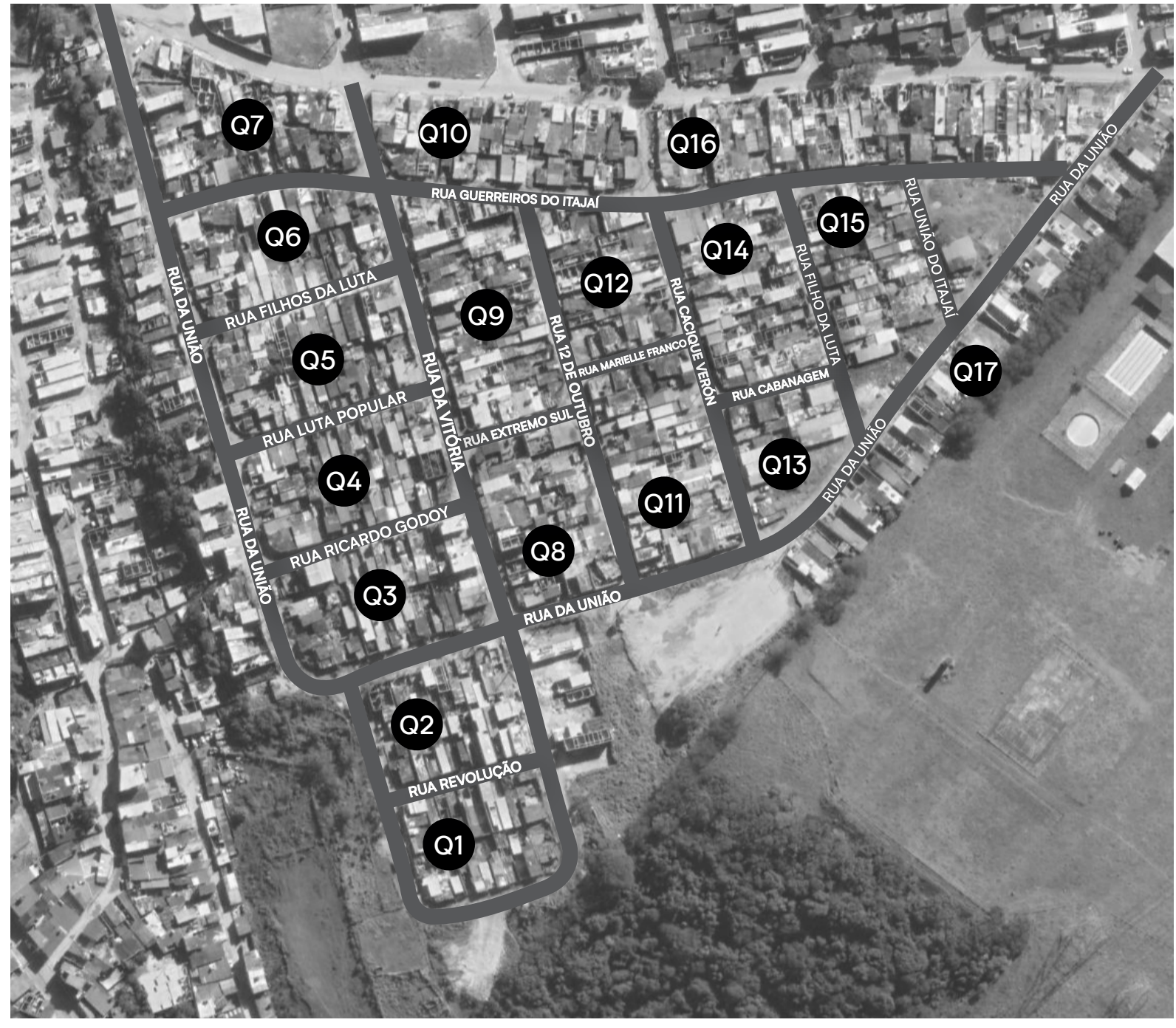

FIGURA 4.19 - Divisão das 17 quadras e nomes das ruas. Elaboração própria.

A primeira casa de blocos foi da Antônia, que fica na quadra 2 , e utilizou os blocos produzidos por um dos moradores. Mesmo com a execução do Plano, a orientação que a Associação passava aos moradores era de não construir em alvenaria, já que seguiam em negociação com a CDHU, até então sem nenhum acordo, e com a insegurança da permanência. Mas Antônia disse: "eu não quero nem saber, eu vou fazer". Depois disso as pessoas que estavam indecisas também começaram a construir em alvenaria e após uma semana já tinha cerca de 10 casas sendo levantadas com blocos.

Ainda que o processo de autoconstrução esteja em curso, já que "casa na favela nunca fica pronta, minha filha" (CAVALCANTI, 2009, p. 72), o caso da construção da casa de Antônia traz luz a alguns pontos interessantes para o debate da autoconstrução hoje. 
E assim, né? Com o meu salário, não é um salário grande, né? Se eu ganhar muito é mil reais. E desse mil reais eu tenho que tirar um pouco pra sustentar os neto, né? Tem que tirar um pouquino pra constuir tem que tirar um pouquinho pro um pouquinho pra construir, tem que tirar um pouquinho pro (Avregando no barraco. as doação vou sustentando os neto (Antônia, CPPATHIS, 2019).

Reconhece-se os próprios limites que o termo "autoconstrução" carrega, já que se refere a um combinado cada vez mais complexo de trabalho próprio e de contratações informais. Apesar de ainda existir o regime de mutirão, este é cada vez menos recorrente à medida que contrata-se cada vez mais mão de obra, seja por diária ou por empreitada (combina-se o serviço a ser executado, independente da quantidade de dias). Em certa medida, é possível dizer que as práticas solidárias diminuem, diferente por exemplo das fases da lona ou da madeira, quando é mais comum a ajuda mútua para a construção das casas. No Jardim da União, viu-se muitas mulheres executando alguns serviços, como o caso de Antônia que construiu o banheiro de sua casa:

A gente é mulher e quando não tem dinheiro pra pagar, faz. Então foi um sufoco [construção do banheiro] mas graças Deus consegui fazer a encanação embaixo do alicerce [.... u abri essa janela pra dar uma ventilação melhor. (Antônia, CPPATHIS, 2019)

Mas para subir a alvenaria, Antônia contratou um pedreiro, morador também do Jardim da União, "somente para colocar" já que ela ficou na função de ajudante:

Esse daqui [levantar as paredes com blocos] eu tive que pagar. Me cobrou barato, né? Porque um dia aí tá cento e cinquenta, cento e vinte, ele me cobrou cem reais, né? Mas, assim pra mim dá até o bloco pra ele, aí eu fazia massa, né? Ele só sentava, né? Eu fazia massa, levava onde ele tava, levava o bloco, o martelo. tudo era eu, né? Dava o lanchinho também, o cafezinho dele, né? Somente a mão de obra pra ele colocar, né? Ficou ainda meio to ". Mas genro falou assim "voce tá doida, botou Uns, importante é que ele fez" Deixa assim, o pior tava, porque tava tudo na madeirite, né? Já tá assim, tá ótimo, né? Falei, graças a Deus já tirei meus bichinho do perigo, né? E tá assim, agora eu vou trabalhar de novo, né? Trabalhar pra poder juntar um dinheirinho, que é pra poder fazer o contrapiso, né? Fazer a encanação. E assim, devagarzinho. Aquilo que eu sei fazer, eu faço, né? Agora aquilo que eu não sei fazer eu tenho que pagar. É dificil, mas devagarzinho nós chega. É só ter uma forcinha de vontade e um empurraozinho forte. (Antônia, CPPATHIS, 2019)
Outro ponto constatado é a quantidade crescente de depósitos de material de construção, tanto no interior do Jardim da União quanto no entorno próximo, bem como a facilitação no parcelamento das compras. Assim, o processo da autoconstrução vai se dando por etapas e prestações intermitentes, sendo que constroem uma logística de que enquanto constroem, também habitam as casas:

Você sabe né, quando a gente não tem dinheiro faz tudo as prestação ne? Então faz um pouquinho hoje, faz um pouquinho amanhã. (Antônia, CPPATHIS, 2O19)

Como dito, a construção em alvenaria ainda está em processo, não é realidade para todos os moradores, como relata Carla:

Minha casinha hoje é de madeirite, ainda não tive condições de fazer de tijolo. Todo mundo que tem suas casinhas aqui é que juntou migalhinha migalhinha para conseguir um coiso de tijolo. Mas a maioria das casas aqui hoje é de madeira e bloco, mas comecemo tudo de lona. (Carla, CPPATHIS, 2019)

Portanto, foi a partir do trabalho coletivo autogestionado que abriram as ruas, delimitaram os lotes, reorganizaram os moradores nos lotes definitivos, reservaram espaços comunitários (como o barracão, por exemplo) e áreas livres e iniciaram o processo de autoconstrução.

\subsection{CPPATHIS}

A proposta do Curso de Prática Profissionalizante em Assessoria e Assistência Técnica em Habitação de Interesse Social (CPPATHIS) não era chegar ao Jardim da União com um programa de necessidades preestabelecido, mas sim com abertura para que juntamente com os moradores isso fosse construído de maneira colaborativa. Foi no contato semanal, nos encontros e conversas, nos almoços e reuniões, que a relação de confiança, fundamental segundo Freire (2019 [1968], p. 230), para o diálogo, foi construída ao longo do tempo, já que "a confiança, ainda que básica ao diálogo, não é um a priori deste, mas uma resultante do encontro em que os homens se tornam sujeitos da denúncia do mundo, para a sua transformação". Estar presente era uma premissa e por isso é possíve afirmar que foram as demandas reais que nortearam o desenvolvimento do curso. 


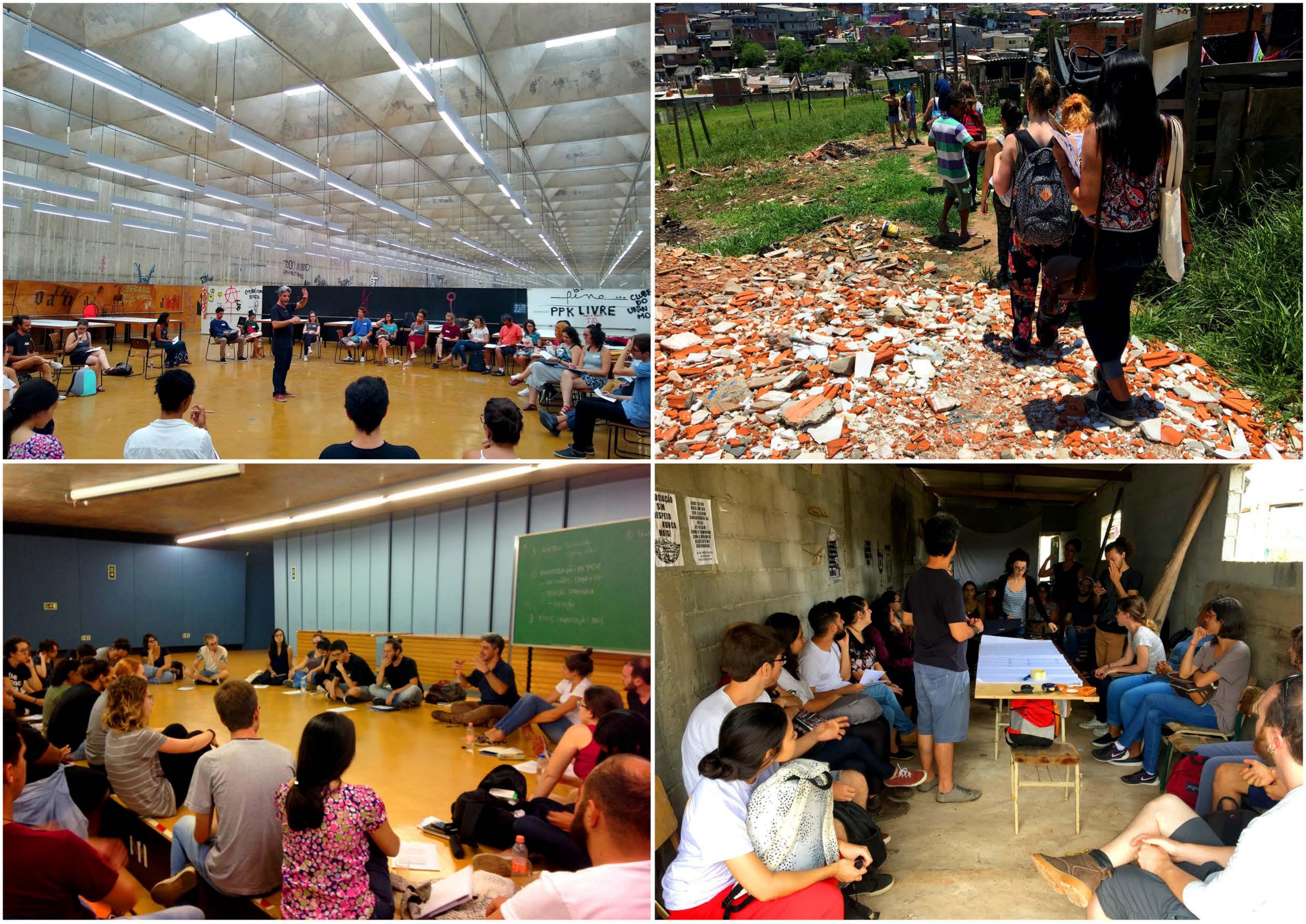




\subsubsection{FRENTES DE TRABALHO}

"A gente não vive, mas sobrevive", foram as palavras da Fernanda no primeiro dia do CPPATHIS. Ela e mais alguns moradores foram convidados para uma conversa na FAU-USP, já que no dia seguinte a esse encontro seria a primeira ida ao Jardim da União. Ao ser indagada sobre o que essa frase significava, continuou que não escolheu morar em um barraco de madeira, a luta que ela e os demais moradores da ocupação enfrentam é pela sobrevivência. Para ela, viver é a partir do momento em que tenha as condições mínimas asseguradas ou até "estudar em uma universidade pública como essa", pois lutar pelo território não é somente pela moradia, envolve diversas lutas. Essa primeira conversa deu o tom com o qual o curso se desenvolveria e antecipou muitas das questões e tensões que seriam vivenciadas.

Nesse dia também foi apresentado o Plano Urbanístico para que, no dia seguinte, com o Plano em mãos, fosse realizada primeira visita ao Jardim da União, acompanhada de alguns moradores que relataram a experiência de autorganização, ou seja, como se deu a produção do espaço a partir da execução do Plano, e como era o dia a dia da ocupação naquele momento. Dessas conversas iniciais começou-se a identificar coletivamente as demandas e como o curso poderia contribuir. dentro dos seus limites e possibilidades, nas lutas cotidianas daquela população.

Como estavam enfrentando um processo de reintegração de posse pela $\mathrm{CDHU}$, entendeu-se que a primeira atividade do curso deveria ser algo que fortalecesse a luta, a fim de contribuir com material técnico para a Defensoria Pública nesse contexto de negociações ${ }^{127}$. Exemplo disso, foi o relatório técnico emitido que demonstrava o impacto gerado pela possíve remoção das famílias ali presentes e que a nova construção de um conjunto habitacional impactaria mais do que a regularização, mesmo porque a quantidade de famílias prevista para esse

27 A entrada da Defensoria Pública para além de contribuir nas negociaçoes reforçou a noção de que os moradores são sujelitos de direitos previstos na constifuição, buscando afastar a construção do discurso da conquista via consumo, como por exemplo da casa.

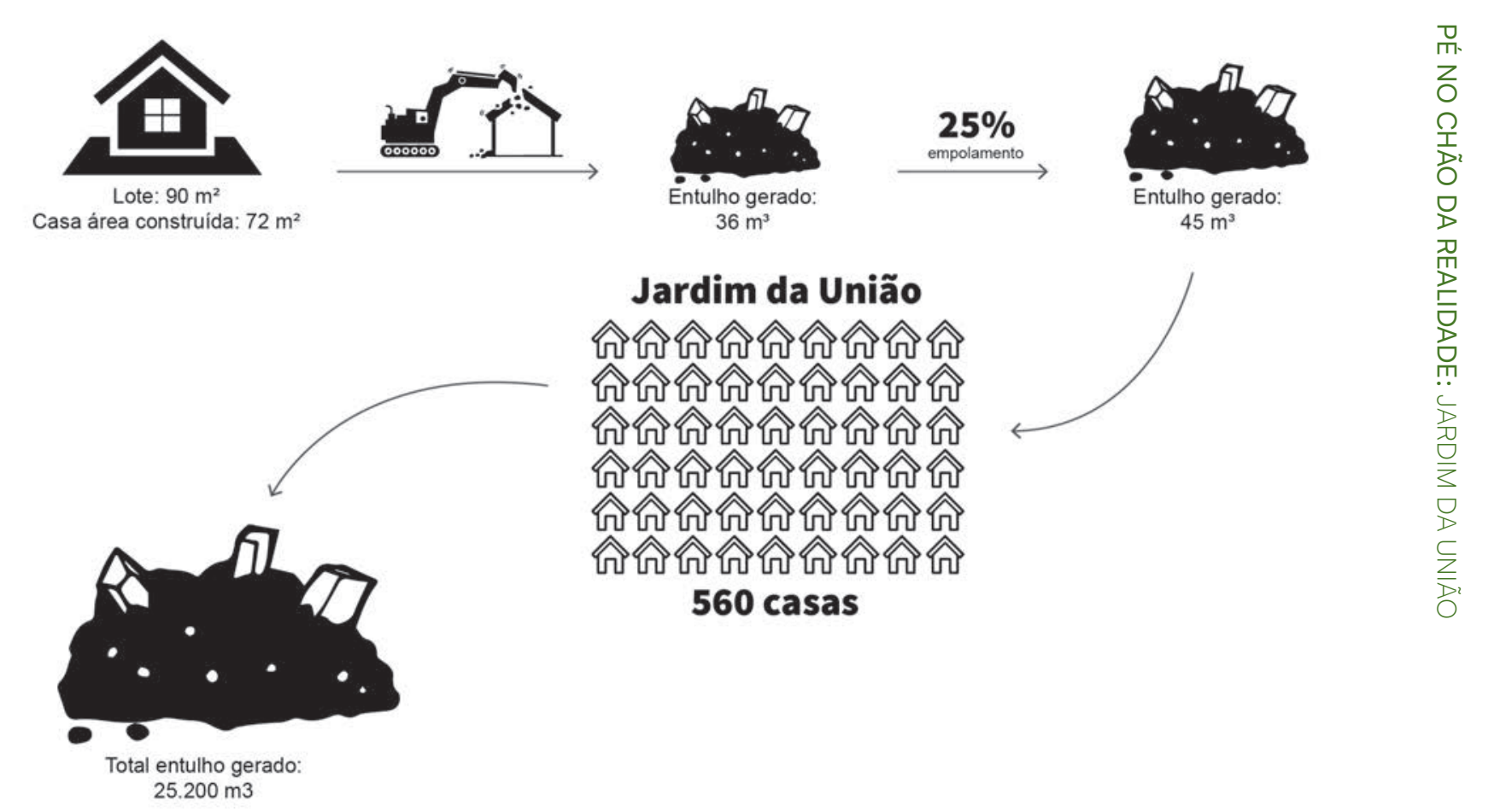

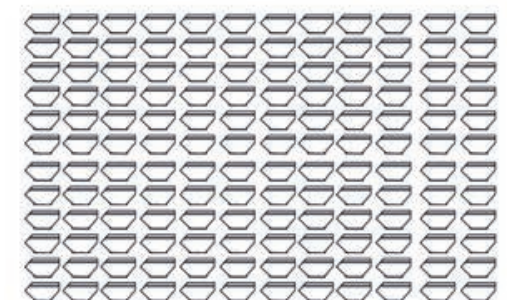

Total caçambas:

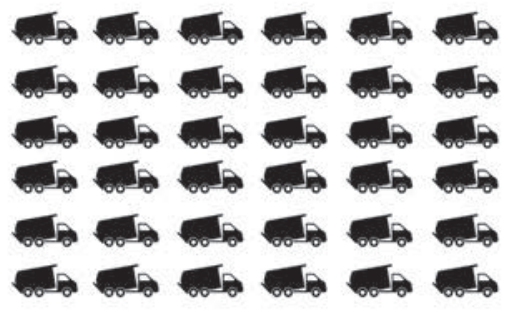

2.100
FIGURA 4.21 - Parte do material preparado para discussão com a CETESP - impactos ambientais de uma remoção.
FONTE: CPPATHIS, 2019.

conjunto era praticamente equivalente ao número de moradores da ocupação (Figura 4.21) ${ }^{128}$. Segundo o relatório:

A remoção das famílias e das casas que ocupam o terreno atualmente deve gerar um volume aproximado de $25.000 \mathrm{~m}^{3}$ de entulho. Esse resíduo deverá ser destinado à aterro licenciado, sendo mais de 2 mil caminhões de $12 \mathrm{~m}^{3}$, movidos a combustível fóssil, para transportar esse entulho. Além disso, a construção de novas 650 unidades (proposta de provisão

128 O relatório partia de uma argumentação técnica do impacto nada sustentável em gerar grande quantidade de entulho e previsão de uma nova construção (conjunto habitacional) para praticamente a mesma quantidade de moradias. Vale destacar também os impactos sociais e psicológicos, como já exposto, que uma remoção forçada causa nos moradores, pois estes consruiram vinculos, constituiram experiências individuais e coletivas, investiram empo, recurso e energia na construção daquele espaço. 
pela CDHU) se soma aos impactos ambientais, tanto por desperdiçar recursos materiais que já foram empregados pelos próprios moradores na construção das unidades e pela pegada de carbono que está presente em grande parte dos mada de carbono que está presente em grande parte dos materais e elementos de construção a serem empregados no novo mpreendimento (cimento, areia, pedra britada, ceramicas. materiais em cobre, alumínio, etc.) (CPPATHIS, 2019)

Assim, os primeiros finais de semana em campo foram dedicados a aplicação de um questionário socioeconômico com objetivo de organizar o cadastro dos moradores, que naquele momento estava desatualizado. $O$ questionário era composto por perguntas sobre a relação dos moradores com a ocupação Jardim da União e com áreas de manancial (tempo da família na ocupação e local de residência anterior), relações de trabaIho e renda (tipo de ocupação e local de trabalho), condições de saúde (deficiências físicas e intelectuais e doenças crônicas), relações de escolaridade e situação das residências existentes (tipo de construção/material e materiais empregados na cobertura e acabamentos).

A respeito do item sobre as residências existentes, a partir do relatório foi possível constatar que das 525 habitações cadastradas, 280 eram de madeira, 238 eram de alvenaria e apenas 7 restavam de madeira e lona. Isso caracteriza o momento em que a ocupação se encontrava quando iniciou-se o CPPATHIS ( $1^{\circ}$ semestre de 2019 ), ou seja, a transição das casas de madeira para alvenaria. Após a reorganização espacial da ocupação, ou seja, a delimitação e demarcação dos lotes, abertura de vias remanejamento das moradias descritos no item 2.4 , os moradores estavam finalizando o processo de mudanças para os lotes definitivos. Em geral, ao mudar os moradores a princípio construíram suas casas com material improvisado, madeirite em geral, reaproveitado da habitação anterior. Portanto, essa era a predominância na ocupação, porém, já estavam na transição para construção das casas em alvenaria, consolidando assim a ocupação, mesmo sem a segurança da posse. Esse processo de transição, que partiu da lona (início da ocupação), passando pela madeira até a alvenaria, muitas vezes foi descrito pelos moradores como "do lixo para o luxo".

Esse questionário foi aplicado a 525 famílias, demonstrando que a ocupação naquele período tinha quase todos os seus lotes ocupados. Segundo o relatório emitido a partir dos dados do questionário, a ocupação conta com quinhentos e quarenta e cinco (545) lotes padrão, de aproximadamente $90 \mathrm{~m}^{2}$ (noventa metros quadrados), dispostos em 17 (dezessete) quadras. Destes lotes, 33 (trinta e três) ainda se encontram vazios (mas já destinados para uma família) e 31 (trinta e um) em processo de construção. Dois lotes foram destinados a equipamentos coletivos - Creche e Sede da Associação.

Concomitantemente a essa atividade, foi realizado o levantamento aerofotogramétrico e posterior vetorização das quadras e edificações. Essa atividade foi feita em parceria com o Grupo de Pesquisa Práticas de Pesquisa Ensino e Extensão em Urbanismo - PexUrb, do Instituto de Arquitetura e Urbanismo de São Carlos - IAU USP. Segundo o professor Marcel Fantin, responsável pela realização do voo, essa ferramenta é "ainda uma ferramenta hegemônica de controle que necessita ser apropriada por comunidades para subverter seu uso e pautar sua existência junto ao poder público, pois muitas vezes elas são apagadas pelos mesmos" e a autora Viana (202O) complementa que "nunca uma conversa sobre tecnologia me sensibilizou tanto, talvez por eu nunca ter vivido com tanta generosidade e verdade essa utilização da tecnologia como subversão da lógica programada e de seu uso para afirmar existências e vidas negadas" (VIANA, 2O2O, p. 180).

Assim, esse levantamento foi importante pois registrou a impressionante execução do Plano Urbanístico, realizada a partir da autorganização dos moradores, o que demonstra a especificidade dessa ocupação. Uma das moradoras ao ver essa foto aérea (foto de 2019 da Figura 4.22) expressou emocionada: "nós fizemos um pedaço de cidade".

Para além do fortalecimento da luta pela permanência, outras demandas foram levantadas, que iam do espaço público até as unidades habitacionais, sendo que só foram elaboradas em virtude dessa maior aproximação ao território e aos moradores. De maneira a otimizar e viabilizar as demais atividades práticas, os cursistas e monitores dividiram-se em três frentes de trabalho: Dados, Melhorias Habitacionais e Infraestrutura, sendo que esta última no decorrer do curso foi dividida em Contenção e Drenagem. Essas frentes de trabalho precisam ser lidas de maneira complementar e de forma dinâmica, no sentido de que não estava clara essa divisão a priori e muito menos os rumos que cada frente trilharia. 
2013

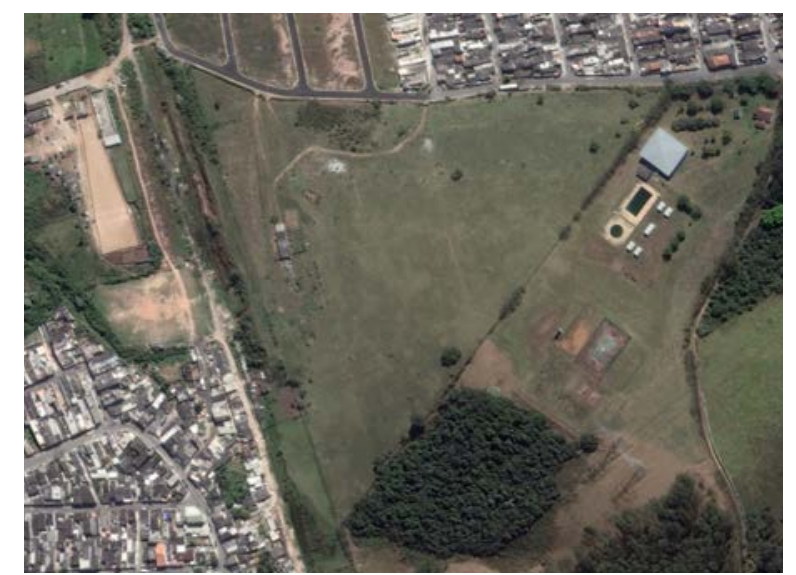

2014

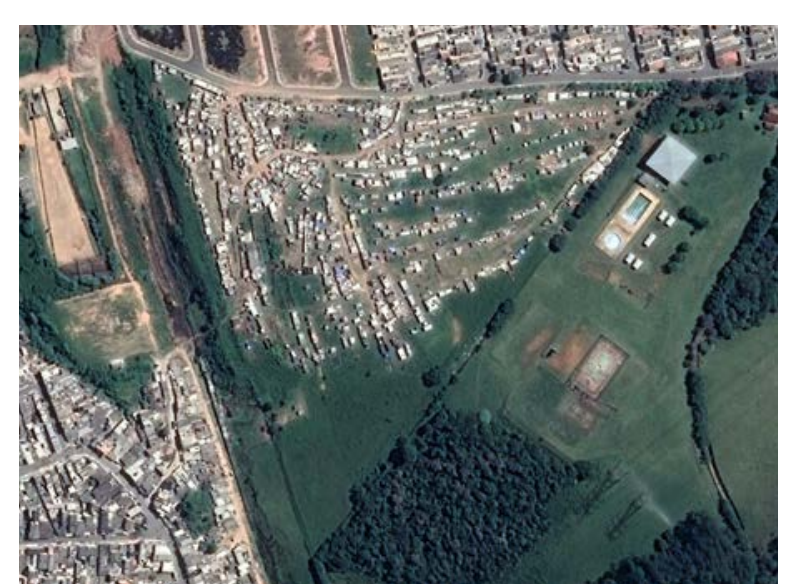

2015

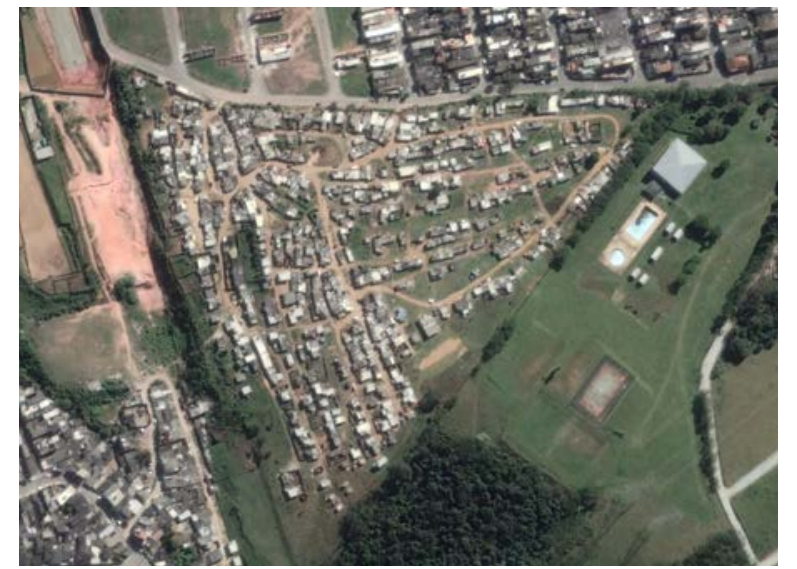

2016

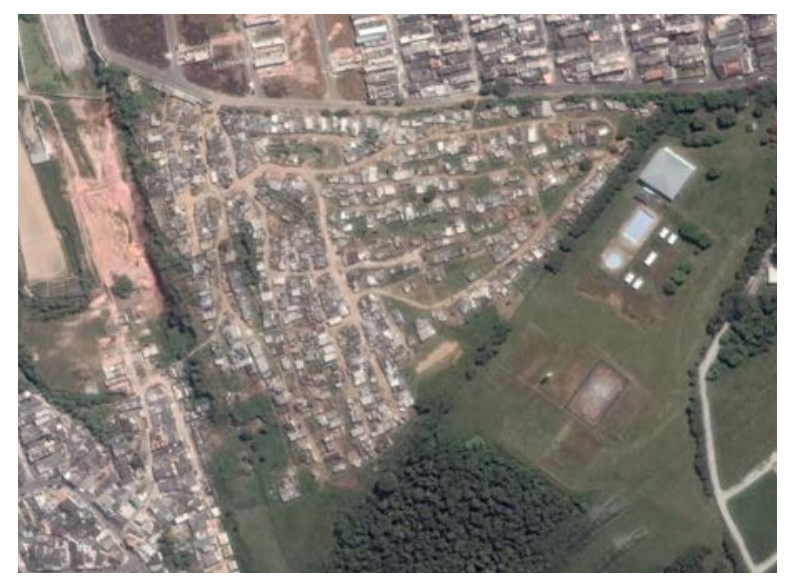

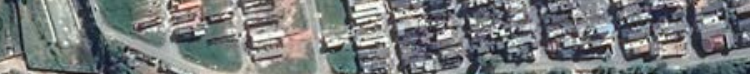

411 mager.

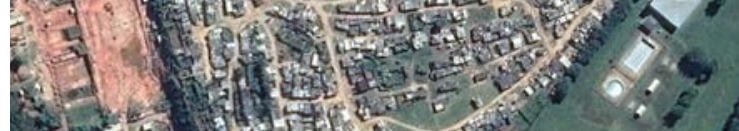

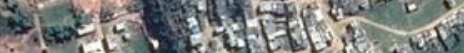

1 dx 5 -

2. $=1 x^{2}$

7 .
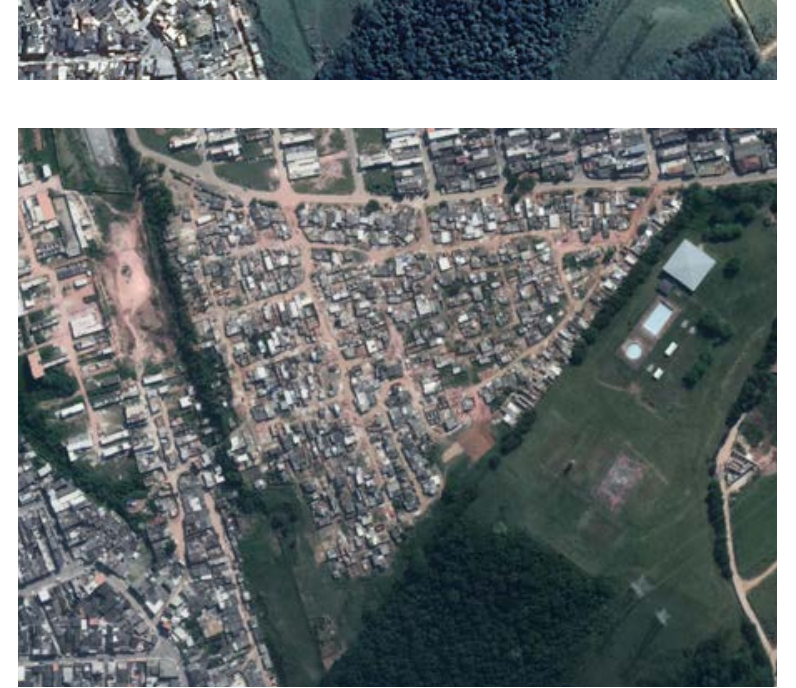

2018
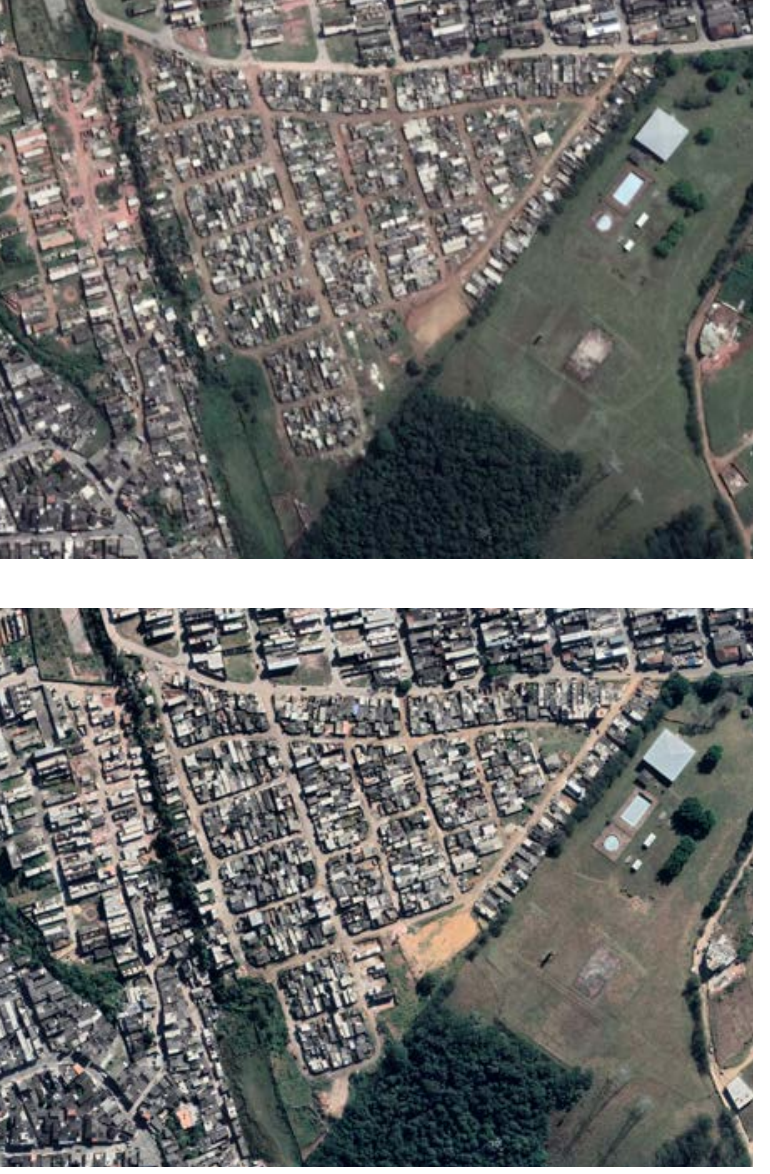

FIGURA 4.22 Sequência histórica da União. 
A Frente de Dados se formou a partir da necessidade de organização dos dados coletados no questionário socioeconômico aplicado para atualização do cadastro das famílias e moradias junto à Associação de Moradores. Além disso, essa frente auxiliou na preparação de material técnico com objetivo de fortalecer a luta pela permanência, contribuindo (com o materia produzido) para a Defensoria Pública nas negociações com os demais agentes públicos envolvidos no conflito. ${ }^{129}$ Por fim, essa frente também foi responsável pela produção de um documentário sobre o Jardim da União. 130

O documentário teve como objetivo avançar dos dados quantitativos para dados qualitativos. Então a ideia inicial foi demonstrar, a partir das vozes dos próprios moradores, que aqueles "números" dos relatórios tinham "por trás" corpos, rostos e vozes, a partir do registro de trajetórias de vida dos moradore que estão intrinsecamente relacionadas com as trajetórias de luta da ocupação. 131

Dessa maneira, o documentário buscou também fortalecer a luta pela permanência, reforçada desde a escolha do título "Jardim da União: o direito de estar", ao enfatizar a vocação do terreno para moradia e a capacidade de auto organização dos moradores, como também a insegurança de permanência devido as reintegrações de posse que é contraditória com argumento da CDHU de remover para para construção de novas moradias.

Já a frente de Melhorias Habitacionais se formou a partir da preocupação com as moradias existentes, sobretudo após a aplicação do questionário que possibilitou visitas às casas revelou a falta de estrutura em casas de alvenaria e boa parte das casas de madeira onde os moradores tinham pretensão de construir em alvenaria. A ideia inicial era buscar intervir em

129 Sobre os agentes públicos envolvidos é possivel destacar a Companhia de Saneamento Basico do Estado de São Paulo (SABESP), a Companhia Ambiental do Estado de São Paulo (CETESB) e a Companhia de Desenvolvimento Habitacional e Urbano do Estado de São Paulo (CDHU), proprietária do terreno.

130 O documentário está disponivel em www.youtube.com/watch?v=Mm89ugv2nJl. Acesso em 23/11/2020.

131 Viana (2020, p. 245) diz que "ao buscar apreender os nexos socioespaciais destes espaços, a máxima da dialética do espaço, de que os grupos sociais produzem o espaço e são por ele produzidos, se revela em sua complexidade". algumas casas da ocupação, mas entendendo que a casa é algo muito individual e como a ideia era ampliar os efeitos dessa frente, optou-se por realizar oficinas com moradores que tivessem interesse em desenho, projeto e execução de obra. Essa decisão foi tomada também pela falta de recursos para reformar as casas e por entender que se tratava de um curso de curta duração. Assim, as oficinas vieram como solução para que essa frente tivesse uma atuação mais coletiva, pois tinham como objetivo disseminar o conhecimento adquirido pelos participantes para melhoria ou construção das moradias da ocupação.

As atividades foram idealizadas juntamente com dois moradores da ocupação, que se autodenominavam como "executores de obra"132 e procuraram mobilizar outros executores locais (já que eram eles que estavam construindo boa parte das casas de alvenaria da ocupação), mas também moradores com interesse nos temas abordados, que iam desde a representação gráfica de uma edificação até a quantificação de material necessário para a construção.

Enquanto que para os membros dessa frente essa iniciativa foi chamada de "oficinas", pois a todo momento reforçaram que se tratava de um espaço de troca de saberes, para os moradores se tratava de um "curso" e foi utilizado o argumento (pelos próprios moradores) de que teria um "certificado da usp" para mobilizar mais pessoas.

Apesar de ter uma programação inicial, as oficinas foram sendo construídas ao longo de cada final de semana, sobretudo a partir do primeiro dia, que foi dedicado à escuta de todos participantes sobre as expectativas e o quais temas gostariam de discutir.

O conteúdo foi dividido em dois blocos temáticos. O primeiro relacionado aos temas ligados à arquitetura, como conforto térmico (ventilação e iluminação), organização espacial (recuos, ambientes), desenho técnico e representação. E um segundo

32 Os trabalhadores ligados à construção civil se autodenominavam "executores de obra". Em conversa com uma das lideranças da Associação, que trabalha com construção civil, o termo "construtores" para ele diz respeito aos gestores de processos e de mão-de-obra, que não trabalham diretamente com a execução de obras. Assim, aqueles que trabalham diretamente em obras, como ele, seriam denominados mais adequadamente como "executores de obra" (CABRAL; DUARTE; TESTOLINO, 2O2O). 
bloco mais ligado à construção, que abordaria técnicas construtivas, materiais e sua quantificação. Esse segundo bloco foi o que mais despertou o interesse dos participantes, para a preocupação dos jovens arquitetos, já que muitas vezes são os temas que carecem durante a graduação.

Nesse sentido, foi fundamental a participação do construtor e pedagogo Sérgio Molina, que se graduou em pedagogia depois de décadas de experiência como trabalhador da construção civil. Ele se juntou à equipe a partir do terceiro dia de oficina, propondo a reorganização das oficinas a partir de uma abordagem mais prática das aulas expositivas. Para os membros dessa frente, ele trouxe "mão da massa" de maneira pedagógica, com a mesma linguagem dos moradores, uma "linguagem prática".

Assim, sua experiência profissional na construção civil e como pedagogo foi importante para a condução das oficinas, como também, ao unir esses dois universos distintos, trouxe a noção de alcançar a liberdade e autonomia através da educação. $A$ partir da transformação da sua realidade, Molina pode ser considerado um claro exemplo da tão discutida educação libertadora freireana, pois para explicação do conteúdo partia da realidade dos moradores, ou seja, qual o tijolo que utilizavam, quais técnicas construtivas empregavam, como construir fundação e estrutura em casas que as paredes já estavam levantadas (questão comum a muitas casas). Além disso, utilizou da mesma linguagem, sem os "vícios" de uma linguagem técnica como é comum aos arquitetos, seja oral ou representativa, pois as abstrações de planta, corte e elevação muitas vezes não fazem sentido no canteiro. Portanto, as questões levantadas trabalhadas estavam situadas na realidade dos moradores e do Jardim da União. Segundo Molina:

Foi uma troca, né? Foi uma troca de interrogações, né? Quem precisava da informação pedia, quem tinha dava. Só que no mesmo momento que você tá ensinando alouém a fazer voce também tá aprendendo, né? Por mais que você tenha vivência voce tá sempre apendendo. Aqui qu aprendi multa coisa. Uma das principais coisas que eu aprendi aqui foi trabar coisa. Uma das principais colsas que eu aprend aqui foitrabalhar em pares, um ajudando o outro, a comunidade envolvida é muito importante, né? Se envolver nesse tipo de tarefa, porque ela acaba animando as pessoas que estão ao redor. E o progresso é evidente, né? Desde o início que a gente chegou até hoje a gente vê que houve avanços, né? E esses avanços se dão pela mobilização e a união do do pessoal da comunidade. Foi muito rica essa troca (Molina, CPPATHIS, 2019).
A construção do saber foi sendo elaborada ao longo das oficinas, com visível mudança de percepção e entendimento sobre alguns temas. Um exemplo disso foi a elaboração das plantas. Apesar do ponto de partida ser basicamente duas tipologias de lotes (o retangular e o de esquina) a ideia não foi entregar desenhos prontos, um produto, mas que cada morador pudesse construir suas próprias respostas, ou seja, o desenho de suas casas. E se no início era comum desenhos em que os ambientes não tinham nenhuma previsão de aberturas ou mesmo a ocupação total do lote, no decorrer das oficinas as janelas começaram a fazer parte da concepção da planta, como também recuos e áreas verdes.

Em um desses encontros buscou-se refletir sobre a importância desses espaços livres para a ocupação como um todo. A dinâmica foi colocar as maquetes das casas individuais, elaboradas pelos moradores, lado a lado, conformando o bairro. Assim, ficou evidente que a previsão desses espaços no lote para absorção da água pluvial, por exemplo, tinha um apelo coletivo. Para reforçar ainda mais essa ideia, membros da frente de Infraestrutura foram explicar o trabalho que estavam realizando nas frentes de Drenagem e Contenção, já que se tratava de temas interligados.

Assim, é possível afirmar que essa foi uma experiência de confluência de saberes práticos e teóricos, em que os envolvidos puderam compartilhar suas vivências e trajetórias, de maneira que todos se (re)educaram, nos termos de Freire (2019 [1968]). Portanto, essas oficinas foram resultado da contribuição efetiva e horizontal de moradores, jovens arquitetos e Molina na construção do conhecimento, a partir dos seus saberes e experiências.

Já a frente de Infraestrutura foi formada pela necessidade de trabalhar questões "da porta para fora", ou seja, do espaço coletivo, que devido às demandas existentes foi dividida entre Contenção e Drenagem. Cabe destacar que a falta de acompanhamento da assessoria na execução do Plano resultou em alguns erros de execução como, por exemplo, casas abaixo do nivel da rua e corte inadequado de taludes, gerando alagamento em casas e risco de desabamento (VIANA, 2O2O). Portanto, essa frente lidou em parte com esses problemas.
FIGURA 4.23 -

Atividades realizadas na Frente de Dados e na Frente de Melhorias Habilacionais - oficinas, apresentação do documentário e censo.
FONTE: CPPATHIS, 2019. 


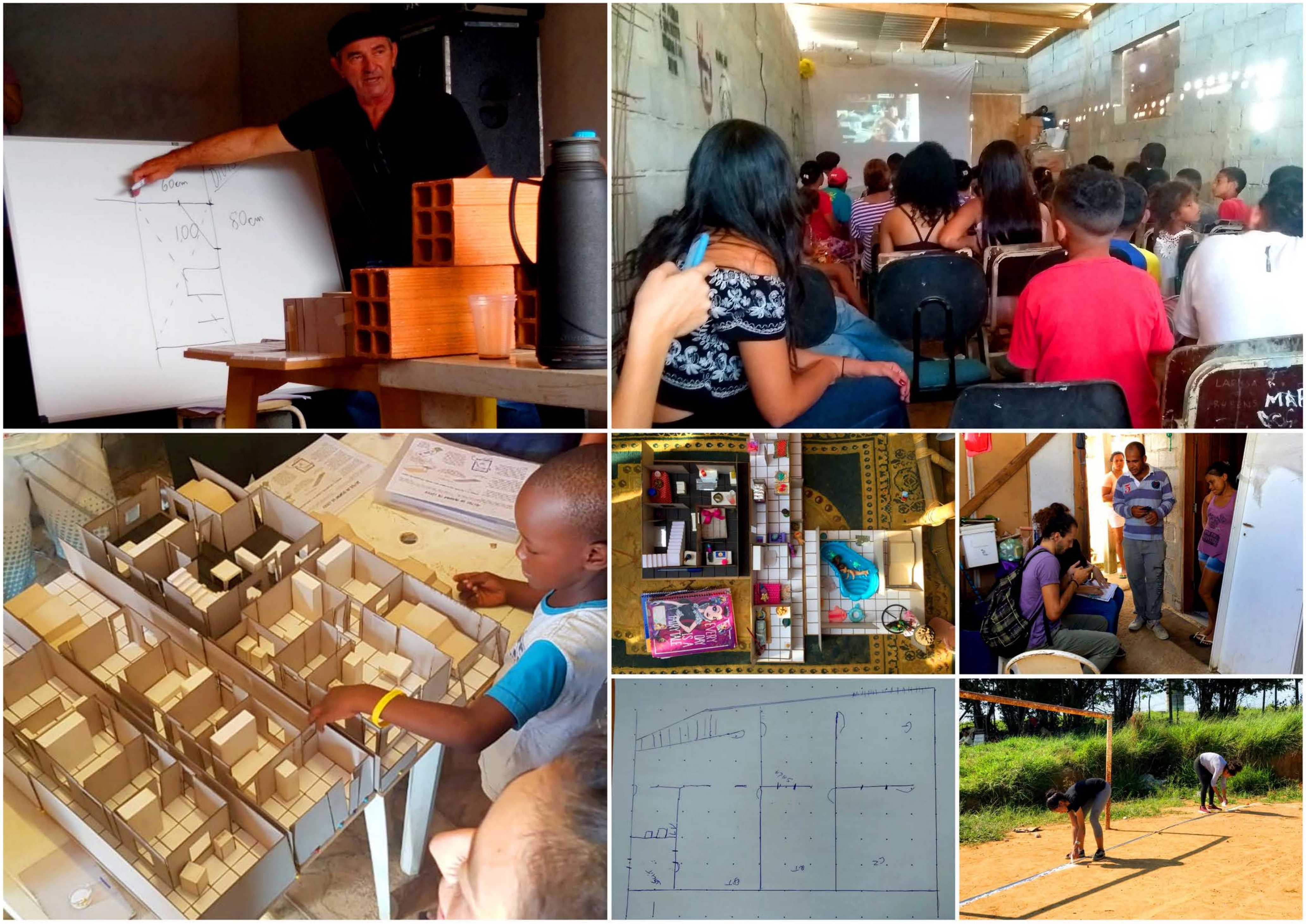


A frente de Contenção foi formada pela necessidade urgente de conter o terreno em alguns pontos da quadra 16 , ocasionado por cortes realizados inadequadamente. Isso somado à topografia resultava em uma significativa confluência de água para as áreas vizinhas.

A questão de contenção, juntamente com a ausência de um dispositivo de drenagem das águas pluviais, revelou a necessidade de estabelecer um diálogo com os moradores, onde os riscos às moradias fossem ser expostos de forma a enfrentar senso comum de que o "problema" era "a água do vizinho". Ficou clara a necessidade de um entendimento da questão como coletiva. Assim, a partir dessa frente, que teve um trabalho praticamente de lote a lote, entendeu-se que havia a necessidade de um olhar mais amplo. Com isso formou-se a frente de Drenagem que tratou do espaço público, pensando soluções para o escoamento da água como um todo.

Em linhas gerais, com processos igualmente repletos de idas vindas, a Contenção desenvolveu algumas soluções técnicas para possiveis muros de arrimo e talude, debatidas com os moradores através de desenhos e maquetes. Já a Drenagem desenvolveu o projeto geométrico das vias, a partir do estabelecido no Plano Popular, e executou um protótipo de um dispositivo de drenagem, a biovaleta. Essa frente, em especial, precisou lidar com algumas dificuldades, como a falta de envolvimento dos moradores - a princípio - nos mutirões organizados, ${ }^{133}$ questões meteorológicas, falta de recursos, ${ }^{134}$ entre outros.

133 A impressão que tivemos foi que após o periodo que tiveram de intensa mobilização e organização dos moradores para execução do Plano, as de mandas tomaram um carater mais da porta para dentro, ou seja, as questoes truindo as casas principalmente em alvenaria Assim principalmente no inci do trabalho da frente de Dreneam poucos moradores participaram das atividades orcanizadas, por exemplo, os mutirões para construcão do protótipo. Mas pouco a pouco, principalmente após um chamado feito por uma das liderancas, como também com a conversa que alguns membros dessa equipe fizeram nas oficinas da frente de "melhorias habitacionais", os moradores

134 A falta de recursos, por exemplo, foi determinante para as escolha dos materiais e dos métodos utilizados na construção do prototipo de um dispositivo de drenagem, chamado biovaleta, que fol executada com corpos de prova doados, e assentados em um trecho escavado a partir de ferramentas tradicionais emprestadas pelos moradores, como pá, chibanca, enxada, em regime de mutirão com participaçăo dos cursistas e dos moradores. Disculimos as atividades dessa frente no seguinte artigo: CABRAL; DUARTE; TESTOLINO, 2020.
Para além de relatar resumidamente as soluções e resultados do trabalho de cada frente, pretende-se refletir sobre as contradições inerentes à prática no território. Entre elas, é possível destacar que cada frente lidou com a paradoxal ausência/presença do Estado na produção capitalista do espaço urbano. Ausência evidenciada pela própria falta de moradia, como também pelos impactos da falta de infraestrutura urbana (como distribuição de água potável, coleta e tratamento de esgoto e drenagem urbana) e com os problemas na escala do privado (como as estruturas das casas e cortes nos terrenos); e presença já que ao longo do curso lidou-se a iminência de reintegração de posse, visto que a proprietária do terreno é justamente a CDHU, companhia de habitação do estado. $O$ Estado que deveria prover direitos à população é o mesmo que cria mecanismos de exclusão e segregação (HADDAD et al., 2019). A fala de um dos moradores demonstra a noção do "direito a ter direitos":

Ocupamos essa terra aqui, que é do governo, da CDHU, entendeu? E é direito nosso, porque o pessoal não tem teto, não tem onde morar. Tem que dar um jeito porque por lei o brasileiro tem direito a moradia, só que isso é tudo mentira né? não é bem por aí que acontece. Então o pessoal tem que se virar, ocupa as terra mesmo e vai continuar ocupar (Marcos, CPPATHIS, 2019).

Além disso, ao longo do CPPATHIS, enquanto a CDHU pressiona as famílias para a remoção, com argumento que teria outros fins para essa área, a Sabesp e a Enel negociaram com os moradores suas entradas para a implementação, respectivamente, de água/esgoto e energia elétrica. Isso demonstra uma atuação contraditória por parte do poder público e das empresas responsáveis pelos serviços públicos, com diferentes negociações com os moradores da ocupação, pois não possuem uma postura conjunta.

Dessa maneira, foi fundamental a reflexão a respeito do papel do curso entre os participantes, que jamais substituiria a intervenção estatal, independentemente das demandas e ações desenvolvidas ao longo dele. A biovaleta, por exemplo, foi por diversas vezes discutida como uma solução pontual e não como um modelo a ser replicado, pois é um dispositivo provisório que tem no horizonte a luta travada pelos moradores pela universalização da infraestrutura provida pelo Estado.
FIGURA 4.24 -

Atividades realizadas na Contenção e Drenagem - reunião com os moradores, maquetes, mutirão para construção da "biovaleta".
FONTE: CPPATHIS, 2019 . 


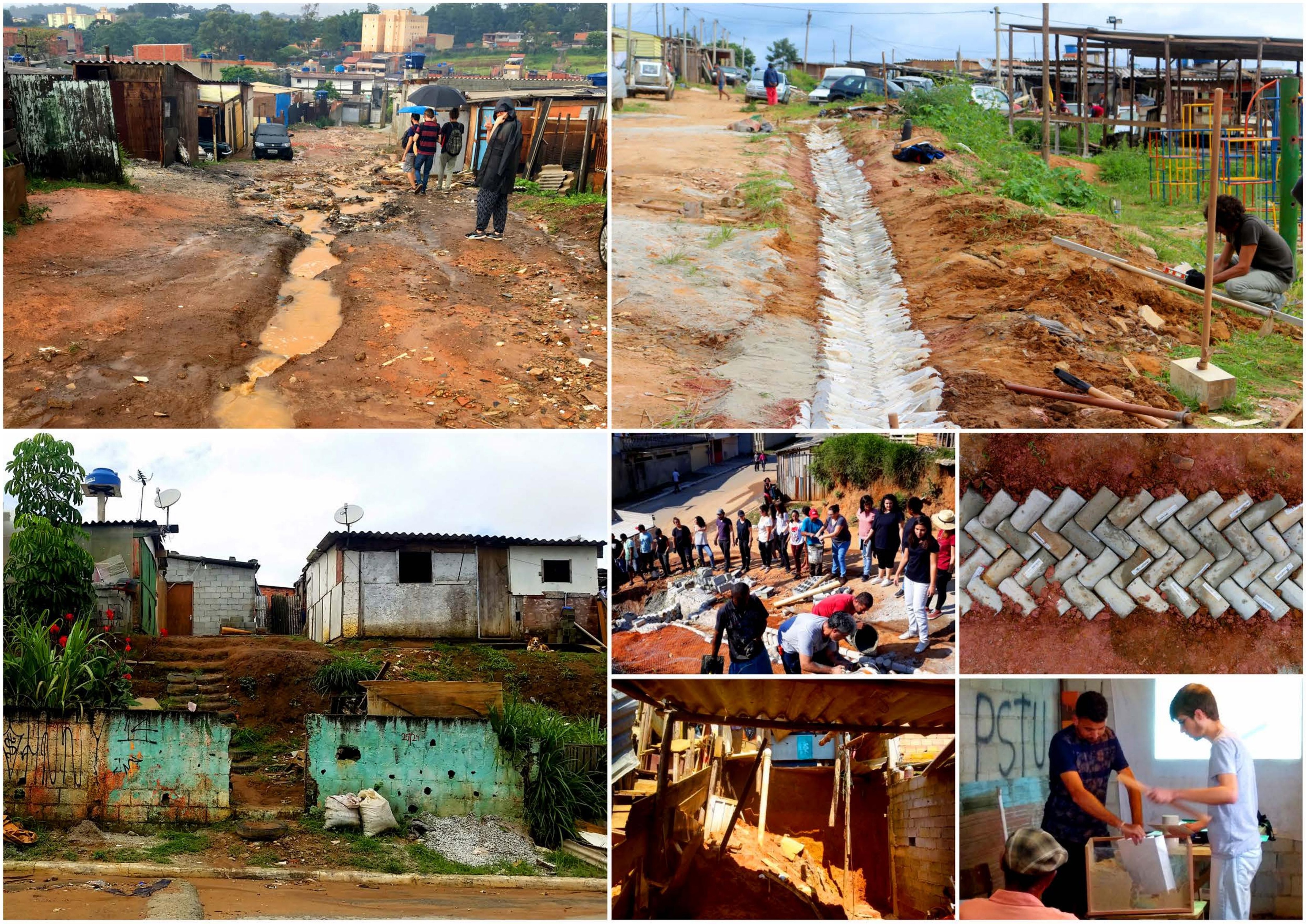


Como uma prática que se desenvolveu ao longo do tempo, é importante destacar as dificuldades, limites e conflitos enfrentados. Na Drenagem, por exemplo, muito foi planejado, mas ao fim foi necessário improvisar. Depois de alguns cronogramas elaborados, ficou evidente a importância de lidar com a imprevisibilidade e iminência dos acontecimentos. ${ }^{135}$ Nesse sentido, estava posto o conflito entre o planejado e o real. Sobreposto a isso, existia ainda o desafio de projetar em um território extremamente dinâmico, como os territórios autoconstruídos comumente são.

Outro exemplo foi a percepção pouco a pouco revelada da tensão que existia entre os moradores do Jardim da União a vizinhança (que não "aceitava" a ocupação), ou até mesmo, entre os próprios moradores dependendo da localização que moravam na ocupação. Em conversas, percebeu-se que havia um senso comum para alguns moradores de que os lotes voltados para a rua asfaltada não faziam parte da ocupação. Inclusive, alguns moradores desses lotes não estavam em harmonia com a Associação de Moradores.

Ainda sobre os conflitos, é importante mencionar o engajamento dos moradores. Pareceu que depois que enfrentaram uma intensa luta coletiva (desde a violenta reintegração de posse sofrida no Itajaí e posterior ocupação e reorganização no Jardim da União) as prioridades tornaram-se mais individuais, momento que coincidiu com o início do curso. Até mesmo porque, como muitos moradores relataram, seu cotidiano é permeado pela luta diária por sobrevivência. Como o processo colaborativo demanda tempo, quando se aproximou o final previsto para o curso foi discutido entre os participantes a viabilidade de adiar esse término.

Durante toda a duração do curso, a Associação de Moradores estimulou constantemente o engajamento dos moradores nas atividades planejadas no âmbito do curso. Assim a todo

135 Alguns imprevistos enfrentados: a frente de drenagem planejou um mutirão mas, quando chegou o dia, não aparecia ninguém ou chovia e não tinha a possibilidade de realizar. Como também, combinar com o 'cara da máquina', que tinha uma retroescavadeira para ajudar na abertura da valeta, já que com as primeiras tentativas percebeu-se que executar somente manualmente com ferramentas tradicionais fugiria muito do cronograma, bem como seria extremamente exaustivo, mas ele não comparecia. Ou ainda, comparecia em algum dia que não estava combinado, fazendo com que a programação para aquele dia fosse alterada. momento a Associação procurava reforçar a importância da participação dos moradores para que o processo fosse de fato construído coletivamente, como também que muito do que estava sendo proposto tinha no horizonte contribuir na luta pela permanência.

Portanto, o CPPATHIS lidou com demandas individuais e coletivas de mais de 500 famílias, que lutam diariamente pelo direito ser, nos termos de Freire (2019 [1968], p. 59), pois, segundo ele, "enquanto a violência dos opressores faz dos oprimidos homens proibidos de ser, a resposta destes à violência daqueles se encontra infundida do anseio de busca do direito de ser."

\subsection{NOVAS DINÂMICAS: \\ PARADOXO DO DESENVOLVIMENTO}

Após a violenta reintegração de posse sofrida em Itajaí (2013), a organização da ocupação Jardim da União (2013), os processos de reintegração de posse que passaram, a elaboração coletiva do Plano Popular (2017), a execução autogestionada do Plano com reorganização da ocupação (2017-2019) e a realização do CPPATHIS (2019), o Jardim da União passa a enfrentar novos desafios. Refletir sobre as novas dinâmicas a partir da entrada de "novos atores sociais" e os conflitos presentes na fase da "ocupação adulta" se impõe como parte do processo de entendimento da efetivação possível do direito à cidade e da produção atual do espaço urbano.

Teresa me chamou para entrar em sua casa. Estávamos tentando manter distância, sem saber ao certo como agir. A quarentena tinha sido decretada naquele mês. Mas quando me chamou, quase como se pudesse falar pelos olhos, não resisti. (...) entrei na sua sala/cozinha. Ela rapidamente, sem maiores explicações, em tom baixo (como se alguém pudesse nos escutar), disse: "o crime entrou". Com os olhos marejados, continuou dizendo que já tinha passado por muita coisa, lutado, enfrentado, que a luta pela ocupação é grande, mas que isso ela não aguentaria. Disse ainda que se essa situacão se confirmasse ela arrumaria suas coisas e iria embora da se conirmasse familia, mesmo sem com sua famia, mesmo sem saber para onde. Tudo isso me tocou profundamente. Na viagem de volta para casa suas palavras repetiam incessantemente em minha mente. Eu já não contia meus pensamentos. Foi uma tarde de muito choro e angústia (diário de campo, março, 2020). 
Dizer que o "crime entrou" pode parecer que antes não existia o chamado mercado informal e ilícito, quando na verdade isso sempre existiu. Assim como em qualquer lugar da cidade, mas muitas vezes é associado exclusivamente aos territórios populares. $O$ que mudou nessa nova fase foi a entrada de alguns membros enquanto facção, onde é possível notar, ainda que recente, algumas mudanças nas dinâmicas sociais, como também a percepção de alguns moradores sobre esse acontecimento. ${ }^{136}$

Com o passar do tempo, houve um deslocamento no padrão discursivo dos moradores. Depois de um período de medo e insegurança, como exposto no registro acima, o que se vê é um processo de aceitação e um certo conformismo: tem que saber conviver. São recorrentes frases, como a da Teresa de que "então é todo mundo junto, mas eu não me envolvo." Ou ainda, como as do Raimundo "eu penso assim: eles tocam as coisas deles, a gente toca as nossas e assim a gente vai levando". Teresa mesmo reconheceu essa mudança de discurso de sua parte:

Naquele dia que você veio aqui, eu tava desesperada. depois eu comecei ir nas reunião, eu comecei a entender a linguagem deles. Eles não vai fazer nada mal pra mim se eu não fiz nada com eles. Não toquei ne? Ai eu falei vamo tentar manter a calma, eles não vai mexer na gente, mas a gente tem que sabe falar com eles, entendeu? Aí a gente começou a entender, não pise no calo deles que eles não vai pisar no nosso. Pronto! Eu passo, eu vejo eles, cumprimento, eu só não me misturo (Teresa, informação verbal, 2020).

136 A partir de conversas com alguns moradores é possivel afirmar que a facção se trata do Primeiro Comando da Capital (PCC). Por esse motivo, considerou-se importante ao longo da pesquisa a elaboracão do Capítulo 3 que contextualiza a expansão do mundo do crime, com o surgimento e fortalecimento do PCC. Digo que a percepção sobre o assunto foi se alterando para os moradores. mas para mim também, pois esse acontecimento alterou o rumo da pesquisa ao trazer novas temáticas e, a partir disso, a maneira como tenho tratado o campo. Gabriel Feltran, em conversa concedida para a pesquisa, alertou a necessidade de buscar entender se seria possivel falar que se tratava da entrada do PCC ou apenas de alguns membros dessa facção que são moradores da ocupação. Indagou: "Inserido nesse território o irmão representa ele mesmo ou a facção?" Após refletir sobre isso e novas idas a campo, ouso dizer que se enquadra numa transição entre as duas coisas: desde o início da ocupação existem alguns moradores "batizados" e nessa nova fase da ocupação (chamada aqui de adulta) há a inserção efetiva da facção nesse território. Essa é uma diferença sutil e de difíci comprovação, já que, como demonstrado no capítulo anterior, a organização do PCC não se dá pela personificação do poder e nem pelo monopólio do mercado ilegal. Uma comunidade é considerada PCC quando há hegemonia politica do Comando no mundo do crime daquele território, que é basicamente a regulação econômica e reivinaicação do monopólio da força e da justiça. Arrisco dizer que seja exatamente isso que está acontecendo neste momento no Jardim da União.
Teresa também demonstrou desde as primeiras conversas saber quais as intenções da entrada deles e contou que dois "irmãos" entraram na sua casa e, sabendo que isso poderia acontecer, ela já tinha guardado antecipadamente o material que tinha sobre a ocupação. Mas, com tristeza na voz, disse que acabou esquecendo de tirar um mapa da ocupação pendurado na parede. Ela disse: "foi a primeira coisa que um dos irmãos viu e logo cutucou o outro para ver também". Sem pedir autorização, "foi logo pegando o celular para tirar uma foto". Rapidamente começaram a se localizar no mapa e entender a organização da ocupação. Fizeram diversas perguntas, com intuito de entender ainda mais a lógica de organização, como por exemplo quantos eram os lotes, quais estavam ocupados e vazios, qual era cada rua do mapa.

Ficaram impressionados com a organização e controle que a Associação de Moradores tinha da ocupação até aquele momento, pois segundo Teresa eles queriam ter o "controle territorial”. Quando indagada se respondeu às perguntas, disse que sim, pois tinha muito medo, principalmente porque estava com as crianças em casa.

De fato, o controle territorial é um dos pontos que merece destaque nessa discussão. Assim como a Associação de Moradores buscava organizar e acompanhar as transformações ocorridas, os integrantes, logo que entraram, buscaram se inteirar sobre a ocupação. A presença constante no território, com intuito de controle, é marcante nas falas dos moradores:

Parece que eles viam eu entrar dentro de casa. (...) Quando eu ia eles perguntavam: "e aí, como tá o Jardim da União? Eu faava: tá bem. Eles falavam: Mas foi tranquila a noite, conseguiu dormir? Eu falei: meu filho, eu sempre dormi bem, aqui nunca ninguém me atrapalhou dormir não, aqui é tranquilo". Então, sabe, eles começaram a pegar informação minha e de outros moradores pra tentar ver se nós tava com a mesma lingus mor. [.] Air a gente comecou a combinar e se alinhar pra falar gem. [... Ar a gente começou a combinar a mesma coisa. Pra eles verem que a gente tava junto, que a gente tava se organizando [...] Eles prometiam segurança, que tavam cuidando da ocupação, que não tem nada a ver né?! Quem segura a gente é Deus e aqui sempre tivemos tranquilidade (Teresa, informação verbal, 2020).

Na maioria das vezes, a presença do crime nas periferias paulistas é fonte primeira de proteção às famílias e são seus integrantes que implementam "justiça” no plano local (FEL- 
TRAN, 2011). Por trás de perguntas como "você conseguiu dormir?" ou "está tudo bem?", que constantemente são direcionadas aos moradores, existe um discurso que busca implementar territorialmente proteção e justiça, já que "o mundo do crime é também ator de gestão de populações" (FELTRAN, 2011, p. 186). Gestão até então atribuída à Associação de Moradores, mas que a partir desse momento passa a disputar legitimidade social com o crime. Assim como frases bem recorrentes como "quem segura a gente é Deus" revela a matriz discursiva das igrejas que também disputam legitimidade, uma vez que é possível notar a expansão das igrejas nessa fase da ocupação.

Como visto no capítulo anterior, o papel que o mundo do crime desempenha, dentro e fora das prisões, é de regulação das normas de conduta, ligadas ou não ao mundo do crime. Quando está inserido em territórios, passando a ser entendido como "instância regradora", que pode gerar medo e/ou se pode recorrer em caso de injustiças, assim como recorrem a uma igreja, imprensa ou Estado. Por esse motivo é possível falar que tem um papel de regulação das relações sociais, inclusive de resolução de conflitos, com imposição de punições, algo que já é possível notar, pois alguns membros têm mediado conflitos cotidianos entre os moradores e a Associação.

Para isso, logo que entraram, buscaram organizar reuniões com membros da Associação de Moradores. Apesar de se tratar de uma reunião em que os integrantes reforçaram que os moradores teriam voz ativa para negociar, muitas vezes acabava tendo um tom de imposição, com frequente demonstração de força e poder (como alteração do tom da voz, demonstração de armas). Deixaram claro que não tinham a intenção de dissolver a Associação, mas, pelo contrário, queriam apoio: "eles nunca pediram para a gente sair da Associação, a Associação tinha que manter, mas a gente tinha que apoiar eles eles tavam com a gente".

Uma mudança notável nessa nova fase é a mercantilização dos lotes, já que a não mercantilização dos lotes foi uma regra acordada pela Associação de Moradores logo no início da ocupação. Entendeu-se que os moradores não poderiam comercializar os lotes, já que estes são direito de quem ali está, zelando por eles e participando da luta. Sob esse viés, o valor de uso se sobressai ao de troca, subvertendo a lógica da mer- cantilização da terra, pois é resultado da produção social do espaço a partir da necessidade. Algumas comercializações já tinham acontecido, mas quando a Associação tinha conhecimento conseguia interromper as negociações. Na tentativa de conter essas negociações, algumas faixas foram espalhadas pela ocupação (figuras 4.25-26). Assim, o controle que a Associação de Moradores possuía, que muitas vezes conseguia suspender a comercialização dos lotes, foi diminuindo pouco a pouco. ${ }^{137}$

A gente sabe que sempre existiu negociação de lotes, desde o começo da ocupação. Acontecia na surdina, escondido, e se Associação soubesse, a gente conseguia barrar. Agora não mais (Raimundo, informação verbal, 2020).

A mercantilização dos lotes é uma das mudanças mais significativas ocorridas no Jardim da União nessa fase mais recente, sendo também reflexo das dificuldades enfrentadas durante a pandemia. Ainda que sabidamente essas negociações existiam desde o começo da ocupação, esse era um princípio muito defendido pela Associação de Moradores, pois entendiam que a consecução da terra é apenas uma das conquistas vislumbradas pela luta do direito à cidade, pois como disse Raimundo: "a uta é muito maior do que um pedaço de terra".

37 Exemplo de um episodio em que Teresa conseguit interromper uma negociação: "eu e mais duas moradoras conseguimos barrar uma [venda de lote] na semana passada, não sei nem porquê. Quando ela [uma das moradoras me ligou falou: Teresa, quando você chegar do trabalho me liga para ir na sua casa? Eu falei que sim. Eu perguntei: mas tá acontecendo alguma coisa? Ela disse: tá, o lote que vocês da Associação passou para minha sobrinha e pra outra moça, que é lote compartilhado, o cara tá vendendo. Eu falel: como assim, o cara tá vendendo? Deixa que quando eu chegar ai ele converso com ele. Quando cheguei lá já comecei a falar com ele, ele já locão [drogado], começou olhar e falou: "mas se teve gente da Associação que ja vendeu, porque eu não posso vender". Eu falei: "aqui é a Teresa, eu não vendi, não troquei meu lote. Ainda existe uma Associação. Tentamo, entamo, falamo tudo e ele como ja tava usando repetia tudo de novo. E eu so querendo vir embora, tomar banho, cansada depois de um dia de rabalho e ele remontava as coisas tudo de novo. [... Ai ele falou: "tudo bem Teresa, amanhă łà liberado." Então Graças a Deus a gente conseguiu barrar, porque se ele chamasse os irmãos, eles iam ajudar ele vender, como já fizeram com outros aqui dentro". 


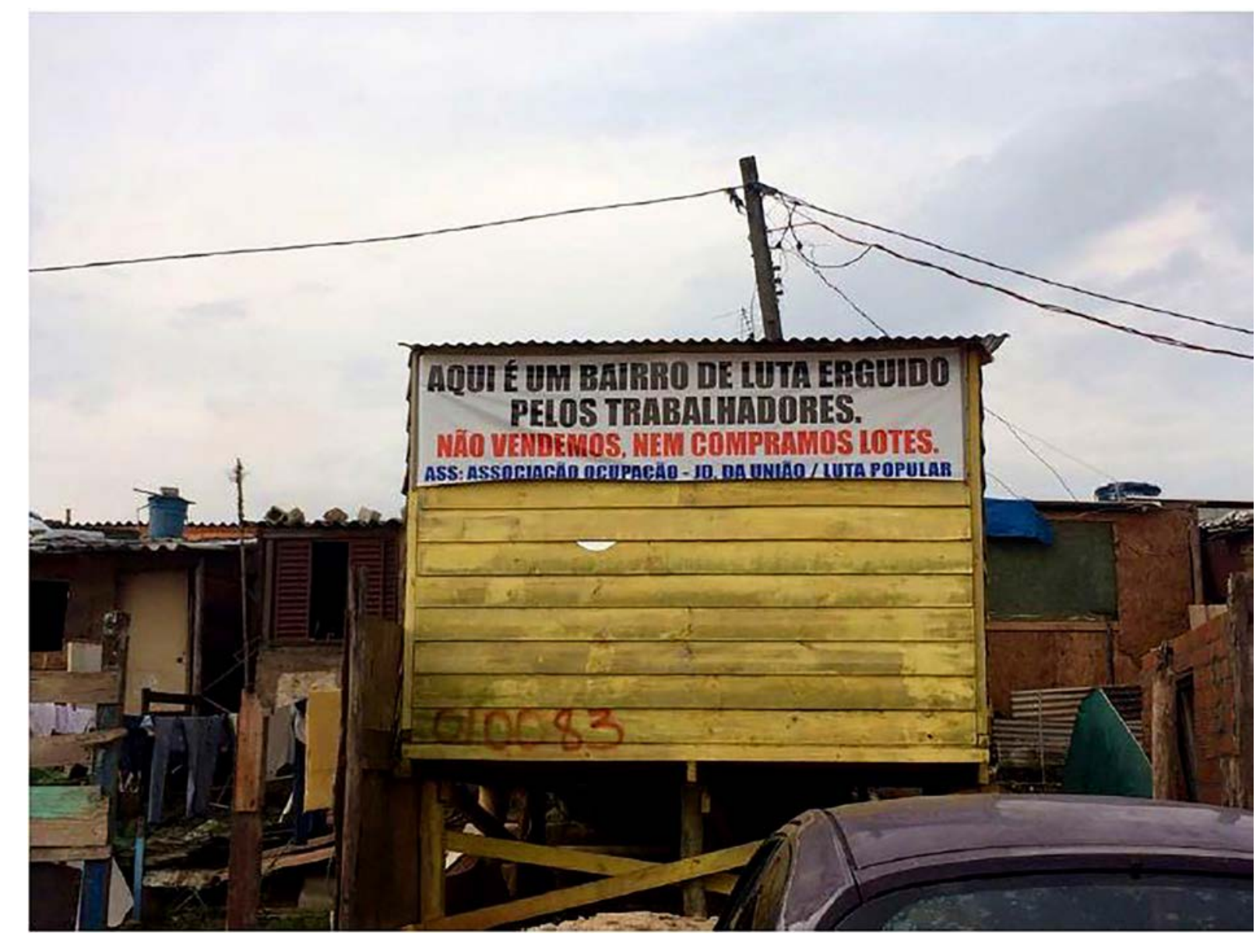

FIGURA 4.25 E 4.26 - Faixas espalhadas pela ocupação para inibição de venda de lotes. FONTE: Larissa viana 2018 e 2019 .

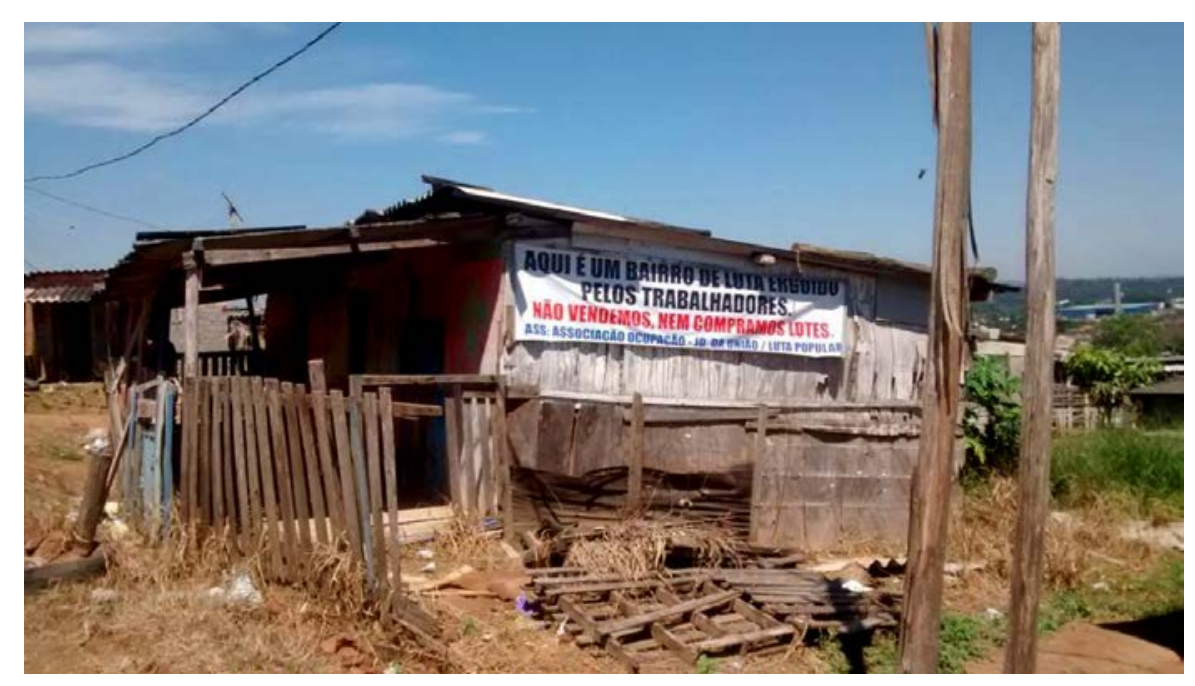

É intrigante pensar que as negociações estão acontecendo mesmo sem ter a segurança da permanência. ${ }^{138} \mathrm{~A}$ disputa pelo solo urbano, independentemente do marco legal da terra, é acirrada, ainda mais dependendo da localização. Alguns moradores acreditam que essas negociações têm acontecido (inclusive com altos valores) devido ao potencial de valorização desse terreno, já que a área onde se localiza a ocupação é delimitada por um terreno da Companhia Paulista de Trens Metropolitanos (CPTM), onde está prevista uma futura linha de trem, que será parte do projeto de expansão da Linha 9-Esmeralda.

No segundo semestre de 2020, a Associação ainda existia, apesar de muitos dos seus membros não participarem mais. Isso aconteceu justamente por não terem mais a autonomia que possuíam anteriormente, além de alguns conflitos internos. Os poucos membros que permaneceram estavam desarticulados, sem conseguir, por exemplo, marcar reunião. Raimundo comenta que "tudo agora precisa passar por eles, os irmãos, até mesmo discussões internas nossas, eles precisam estar mediando", assumindo assim um papel de mediação.

Consequentemente, os moradores também estão desmobilizados, até mesmo pela intensa rotatividade de moradores a partir da comercialização de lotes. Como a Associação não consegue mais suspender as negociações de lote, muitos moradores saíram e tantos outros entraram no Jardim da União.

Sobre a desmobilização dos moradores, Teresa entende que tem uma relação direta com o fato de que considerável número de moradores atuais não estarem desde a formação da ocupação, não participaram da luta desde o início:

Me perguntaram esses dias: "Teresa você acha que se a gente tiver uma reintegração, alguma coisa assim, a gente consegue levar uns quatro ônibus pra rua?139 Eu falei: eu acho que não, porque porque eu ho he aqui. Mas vamos supor, eu pego meu terreno e vendo para

138 De acordo com conversas informais com os moradores, o valor por lote é em média de $\mathrm{R} \$ 25.000,00$. Teve até mesmo um caso de lote vendido por $\mathrm{R} \$ 80.000,00$

139 Muito provavelmente se referindo ao episódio do CDHU que foram protestar contra a suposta reintegração de posse destinada ao Jardim da União e conseguiram preencher três ônibus, como relatado no "3.3.1. A luła pela permanência". 
Ana [nome fictício]. Aí a Ana chega aqui e não sabe nem o que a gente sofreu, porque quando eu cheguei não tinha água não tinha luz, não tinha nada né? Até os meninos lembra de nós lá embaixo tno lote anterior à reorganizaça da a ocupaçáo]. (..) nosso barraquinho era tão precário e hoje nós temo um barraco maior. Porque era bem pequeninho inha muito pernilongo e esses meninos ficam doidos. Me Deus, não dá nem pra contar. Hoje tá bem, é de madeira mas é maior que dá para colocar todas as coisas, lá embaixo não. Então quando eu passo o meu terreno para outra pessoa que chega hoje não sabe a luła que a gente já teve pra trás. A gente já queimou pneu na rodovia, sabe assim de parar tudo?! Teve uma vez que a gente pegou um caminhão e levou fogão geladeira colchão, levou tudo, que a gente conte dentro do CDHU. A gente foi com tudo e paramos aquele prédio. [.] Mais ou mente foi com tudo e paramos aquele predio. [... Ma. Mais ou menos tres onibus de gente dentro do CDHU, não dava nem pra respirar de tanta gente. Fizemo comida, almoço, lanche da tarde. Aí quando eles viu que gente não ia sair, eles liberou. Deu mais 180 dias pra gente. (Teresa, informação verbal, 2020).

Fernanda diz que há duas lutas no horizonte do Jardim da União: uma interna, para "mobilização do povo", e outra externa, "com os de cima". E continua: "mas como organizar o povo se eles chegam aqui através da compra de lote e não sabem de que já passamos?". Já Raimundo diz que tem a impressão que para muitos moradores a luta parece ter acabado, quando na verdade ele ainda vê muita luta pela frente. Por isso insiste que a luta precisa recomeçar. Um exemplo do que o preocupa é o próprio destino da negociação que estava em curso com a recém extinta CDHU. Não se sabe até o momento qual o destino dos terrenos que pertenciam à Companhia, muito menos como se dará a continuidade dos processos que estavam em andamento, como no caso do Jardim da União. Como também considera que a Associação de Moradores, historicamente à frente da organização, não tem condições de disputar poder/ legitimidade com os moradores perante o crime, por isso só cabe a eles aceitar essa nova configuração.

Como medir força com esse poder que tá aqui dentro hoje? Não tem como medir, comparar, então só resta a gente aceitar [...] Hoje eu considero que o Jardim da União não tem mais uta no horizonte. Antes tinhamos, mas hoje não mais. Talvez no futuro recomece. Hoje com a pandemia, com a necessidade de conseguir doação, as campanhas políticas, a entrada do crime e outras coisas, as pessoas estão mobilizadas para

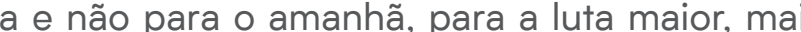
longe (Raimundo, informação verbal, 202O).
Há de fato as reivindicações imediatas, sobretudo pelos impactos da pandemia (como por exemplo o aumento do desemprego), ${ }^{140}$ mas o que Raimundo procura reforçar é que os moradores não podem esquecer que há uma luta maior no horizonte. Os moradores estão mobilizados para atender as necessidades imediatas, às demandas urgentes, como por exemplo sobreviver em meio a pandemia. Inclusive, procurar meios para arcar com as contas de água e energia, pois concomitantemente aos acontecimentos relatados nesse período, houve a instalação das redes de água e esgoto pela Sabesp e de energia elétrica com postes da Enel. ${ }^{141} \mathrm{~A}$ instalação sempre foi um desejo para os moradores, já que para além das meIhorias das condições de habitabilidade que a inserção dessas redes geram, existia o desejo pelo comprovante de endereço, como relatam Helena e Carlos:

Nós temos fé em Deus que um dia a Eletropaulo entra aqui coloca e legaliza pra nós. Depois que regularizar água e luz nós tem pelo menos um comprovante de endereço. Quando eu vou no banco, em tudo ponho meu endereço é da casa da minha fia, eu pego minhas cartas, minhas correspondência tudo lá, porque aqui nós não tem endereço fixo. Mas um dia nós vai ter, com fé em Deus (Helena, CPPATHIS, 2019).

Outra coisa, nós já temos uma rua que nós já vai colocar as placas, o nome da rua, já tão tudo programado, né? E nós vamos por esse nome da rua pra todo mundo ter seu endereco cortinho, né? Sua mor co ce pra não dar problema, pra receber una carta, fazer um crediário em algum lugar, pra nós não ser abandonado, porque nós não pode ser abandonado, né? [...] E uma coisa que nós, eu acho que nós merece, né? Isso aqui. Nós merecemos isso aqui, vai ter todo apoio do pessoal que vem de outros lugares, né? Pra ajudar nós aqui, porque nós depende deles também (Carlos, CPPATHIS, 2019).

Com o comprovante de residência em mãos, algumas burocracias do dia-a-dia são facilitadas, como cadastros, uso de serviços da região, matrículas, recebimento de mercadorias, a

140 Em pesquisa divulgada em junho de 2021 pelo IBGE, que analisou o trimestre de fevereiro a abril de 2021, o índice de desemprego foi 14,7\%, o maior (2012) e com aumento de 3,4\% se janeiro). Isso significa que trabalhadores desocupados.

141 A instalação da infraestrutura iniciou-se em 2020 e em agosto de 2021 ainda não foi concluida, mas já se encontra na fase final. 
procura de trabalho, bem como "o endereço de uma moradia considerada "regular" amplia a própria percepção de inclusão na sociedade e nas instituições no capitalismo" (FERRARA GONSALES; COMARÚ, 2019, p. 12), o que Carlos chamou de "não ser abandonado". Porém, em contrapartida, muitos moradores estão relatando as dificuldades financeiras para o pagamento das contas, como também alguns valores exorbitantes. A instalação das redes em um território marcado pelo conflito fundiário, como é o caso do Jardim da União, demonstra a simbiose entre o legal e o ilegal, discutida no capítulo 1.

Nesse sentido, é possível constatar que são duas as frentes de luta para as ocupações urbanas recentes: a expansão dos serviços urbanos, algo conquistado com luta pelo Jardim da União, mas também a desmercantilização desses serviços básicos, que deveria se estender a todos, sem exceção. De acordo com Lago:

A luta por serviços urbanos públicos é uma luta histórica dos movimentos sociais e dos intelectuais comprometidos com democratização da cidade. Com a privatização dos serviços a partir dos anos 1990, o Estado somou a uma situacão histórica de exclusão - áreas periféricas sem fornecimento dos serviços - exclusao areas perfécas sem forno - uma nova siluaçá: famichas sem condiçóes de arcar com usto das farifas, onde os serviços chegaram (LAGO, 2019, p. 44 , grifo meu).

Ainda sobre conseguir sobreviver em meio à pandemia, vale destacar dois projetos iniciados no Jardim da União na fase atual da ocupação. O primeiro é o Programa "Costurando pela Vida”, realizado pelo município de São Paulo, por intermédio da Secretaria Municipal de Desenvolvimento Econômico Trabalho, a partir de abril de 2020 , que tem como objetivo a qualificação profissional e o empreendedorismo para pessoas em condição de vulnerabilidade social. ${ }^{142}$ Alguns moradores do

142 Segundo o edital do Programa: "A presente convocação tem por objefivo oportunizar que Organizaçoes da Sociedade Civil - OSC apresentem projetos que versem sobre ações de estimulo ao empreendedorismo de pessoas em situação de vulnerabilidade por meio da fabricação de dispositivos médicos identificados como prioritários conforme Resolução de Diretoria Especializada - RDC ANVISA no 356 de 23 de março de 2020, com o intuito de estimular oportunidades de geração de renda no setor têxtil e artesanato no Municipio de São Paulo, no âmbito da ação "Costurando pela Vida" (PMSP-SMDET, 2O2O, p. 1, grifo meu).
Jardim da União participaram do projeto, sobretudo as mulheres e os imigrantes. ${ }^{143}$

Carolina, moradora do Jardim da União, estava desempregada durante a pandemia e participou desse programa. Ela conta que confeccionou máscaras, propés e gorros e para atingir a meta do contrato trabalhava diariamente de 8 a 10 horas na máquina de costura, com um rendimento que era somente de subsistência. ${ }^{144}$ Para ela "é uma falácia dizer que a mulherada é empreendedora", pois na verdade são trabalhadoras precarizadas, sem os direitos trabalhistas assegurados. Além disso, disse que se tratou de algo temporário, logo que acabou o seu contrato se viu novamente desempregada e segue sobrevivendo de "bicos". Sobre a ideia do programa, afirma que a ideia é boa no sentido de girar a economia interna, mas não concorda com a forma, pois, nas suas palavras:

Tem todo um ar das costureiras como empreendedoras, né? Dona do seu próprio negócio... isso para mim é falácia, na verdade isso para mim foi praticamente trabalho escravo, viu? para mim foi semi escravidão, porque é um trabalho exaustivo costurar, não é fácil você ficar mais de 8 horas na máquina e às vezes eu ficava muito mais que 8 horas, ficava 12 horas para dar conta do serviço [...] é muito pouco para se manter no dia [a renda] Imagina, a maioria são mulheres, negras, da periferia e mães solteiras, então é esse perfil á, Então ção verbal, 2021).

O outro projeto se refere à construção de uma horta comunitária em uma das áreas livres previstas no Plano Popular e foi iniciado no primeiro semestre de 2021 (Figura 4.27). Essa iniciativa tem sido realizada a partir do apoio e capacitação dados pelo Luta Popular, com formação teórica e prática aos finais de semana para os moradores interessados. É possível mencionar alguns objetivos desse projeto: (1) contribuir para geração de alimentos e de uma possível renda, algo tão importante nesse momento de crise econômica e carestia dos

143 A entrada de moradores imigrantes no Jardim da União é outro fato que foi possivel nołar nessa fase da ocupação, principalmente oriundos do Haiti e da Bolivia.

144 Carolina contou também que em média recebia, com os descontos, $\mathrm{R} \$ 1.000,00$ ao mês. Mas isso variava do contrato de cada costureira e se atingia a meta. E, ainda, todos os gastos com a maquina de costura (e manutenção), energia, alimentação etc. ficaram a cargo das costureiras. 


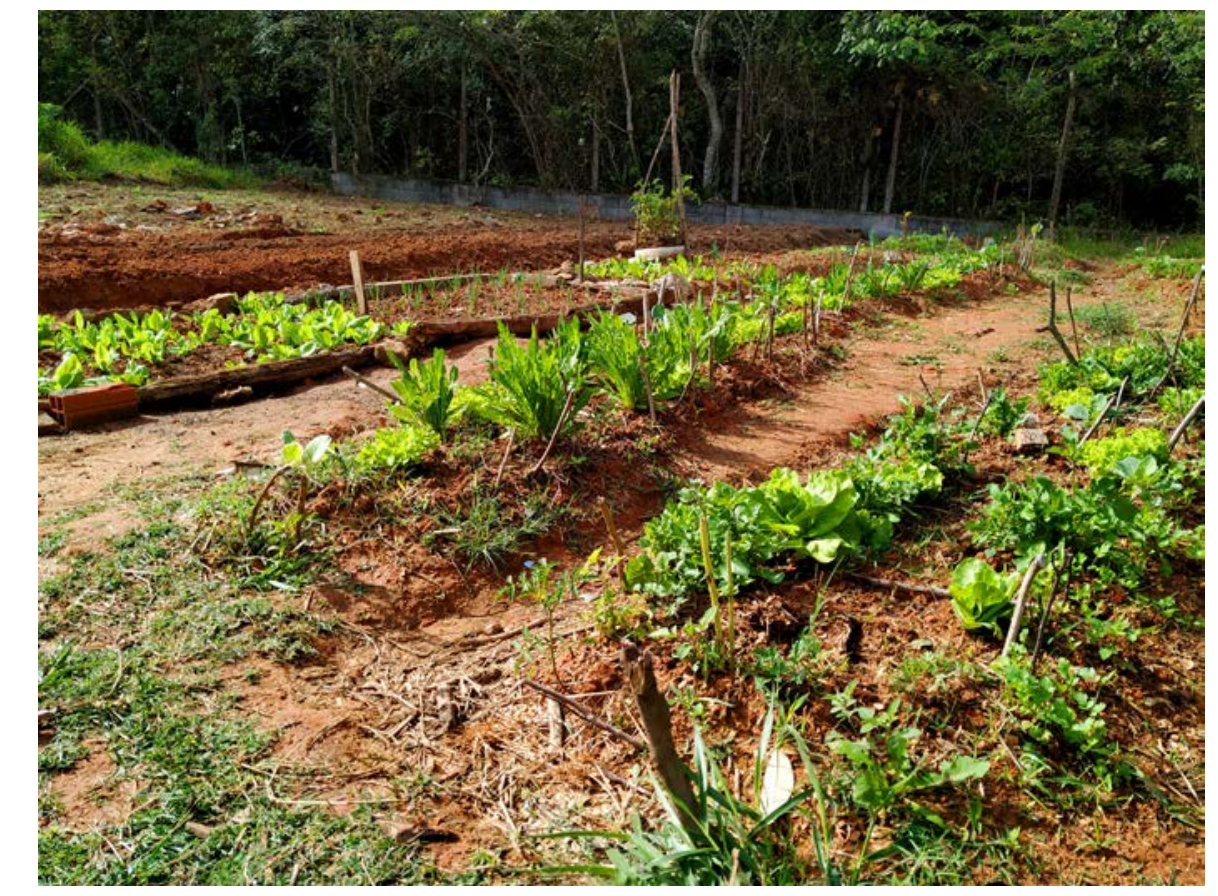

FIGURA 4.27 - Horta comunitária na ocupação Jardim da União.

FONTE: Acervo da autora, 2021.

alimentos; (2) propor uma atividade para essa área verde, pois a Associação está passando por um momento complexo para conter a ocupação das áreas livres e, sabendo da importância desses espaços para a regularização fundiária, estão procurando propor usos para essas áreas; (3) mobilização dos moradores, portanto engajar mais moradores na construção de um projeto coletivo, que não traz somente benefícios em uma escala individual, mas para a luta coletiva da ocupação, fortalecendo assim a coesão interna.

O projeto das hortas comunitárias faz parte da iniciativa da nova gestão da Associação de Moradores, com o objetivo de reorganização e mobilização dos moradores (dos novos que não tem o "histórico de luta", mas também dos antigos que estão pouco engajados). Alguns membros da antiga Associação de Moradores se organizaram para formar uma nova equipe e convidaram outros moradores, sobretudo aqueles que estão desde o início.

Uma das primeiras atividades dessa nova gestão, que aconteceu concomitantemente com a formação das hortas, foi a aplicação de um novo censo. ${ }^{145} \mathrm{~A}$ nova equipe entendeu

145 Nome dado pela associação para o levantamento cadastral socioeconómico das famílias, assim como o realizado em 2019 no âmbito do CPPATHIS. que a primeira demanda seria entender como se encontrava a ocupação naquele momento, após tantas mudanças. Para isso, com auxilio de alguns participantes do CPPATHIS, revisamos o questionário aplicado em 2019, acrescentando perguntas que procuraram identificar os impactos ocasionados pela pandemia e quais as atividades os moradores gostariam que a ocupação tivesse.

Entre junho e julho de 2021, aos domingos, foi realizada a primeira fase da aplicação que enfrentou algumas dificuldades. Primeiro, por ainda nos encontrarmos em um contexto de pandemia, discutiu-se as condições de como realizar esse levantamento da forma mais segura possível. É possível pontuar uma segunda dificuldade no que se refere à participação dos moradores, pois, apesar do esforço constante da Associação, muitos não sabiam da existência do censo, ou ainda, quando sabiam não entendiam os seus motivos.

Logo nos primeiros domingos foi possível perceber que de fato existiam muitos moradores novos e que, portanto, não tinham participado do censo de 2019, tampouco de todo o histórico de luta da ocupação. Vale ressaltar também, duas mudanças em relação ao censo de 2019: (1) a aplicação do questionário foi feita principalmente pelos próprios moradores, enquanto que no censo de 2019 os moradores não participaram da aplicação. Processo repleto de desafios, como a própria linguagem e a maneira como as perguntas foram elaboradas; (2) nos primeiros domingos a aplicação foi feita de porta em porta, assim como foi o censo de 2019, mas sem entrar na casa por conta das restrições que a pandemia impõe. Mas depois do terceiro dia, decidiu-se que seria melhor fazer um "plantão do censo", num espaço ao ar livre para que os moradores pudessem ir e responder ao questionário. Esse "plantão" aconteceu na área institucional, prevista no Plano, onde construíram uma cobertura e onde são realizadas as assembleias e reuniões, já que se trata de uma área ampla e aberta (Figura 4.28).

Essa estratégia deu "visibilidade" para o censo. Com pessoas reunidas debaixo da cobertura, quem não sabia o que estava acontecendo logo procurava se inteirar. Foi possível notar uma movimentação na ocupação no sentido de um vizinho chamar o outro para ir até o "plantão". E, ainda, quem se dispunha a sair de sua casa para ir ao plantão já estava disposto a responder às perguntas. Muito diferente de quando alguém bate à porta, 


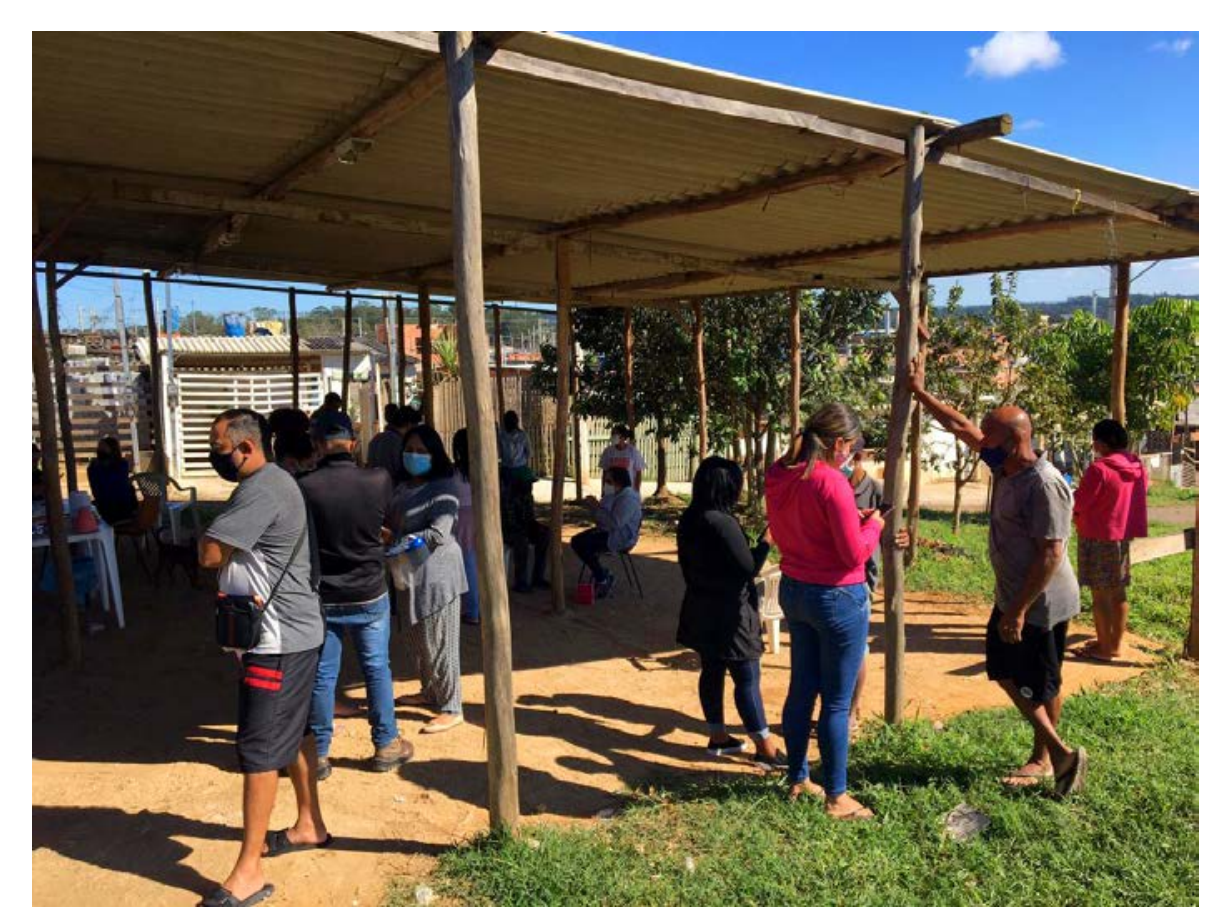

FIGURA 4.28 - Censo realizado no primeiro semestre de 2021 no Jardim da União.

já que a sensação que tínhamos, por vezes, é que estávamos incomodando a rotina da família. Essa mudança foi necessária porque estimou-se que, se continuasse no mesmo ritmo dos primeiros domingos, iria demorar muitos meses para a aplicação do censo em toda a ocupação.

Ainda que os dados do censo estejam em processo de correção e análise, bem como termos entendido que esses seis domingos seguidos finalizaram uma primeira etapa da aplicação do censo, é possível trazer alguns dados, ainda que preliminares, para iluminar algumas questões da fase atual do Jardim da União. Ao todo foram entrevistadas 448 famílias e 1.295 pessoas, o que mesmo não correspondendo a toda ocupação já representa uma amostra importante (o censo em breve terá uma segunda fase de aplicação). A seguir alguns dados:

1. A aplicação do questionário demonstrou que de fato estão no processo de construção das casas em alvenaria. Ainda que a pandemia tenha interrompido esse processo para muitas famílias, como muitos relataram, há pelo menos 304 casas em alvenaria, sendo que esse número em 2019 correspondia a 238. Há ainda 144 casas em madeira, mas a grande maioria com pretensão de construir em bloco, sendo que em 2019 esse número era 280. As 7 casas de lona existentes em 2019 não existem mais (Tabela 4.1). Como o total das casas não é o mesmo para os censos de 2019 e 2021, considerou-se importante pensar em termos percentuais, como demonstrado no Grafico 4.1 e 4.2.

TABELA 4.1 - TIPO DE CONSTRUČ̃̃OMATERIAL

\begin{tabular}{lcc}
\hline & 2019 & 2021 \\
\hline Alvenaria com estrutura & 119 & 187 \\
Alvenaria sem estrutura & 71 & 74 \\
Alvenaria e madeira & 48 & 43 \\
Madeira & 280 & 144 \\
Madeira e lona & 7 & - \\
TOTAL & 525 & 448 \\
\hline FONTE: CPPATHIS, 2019 e. Associação de moradores do Jd. da União, 2021. \\
Elaboraçăo própria.
\end{tabular}

GRÁFICOS 4.1 E 4.2 - TIPO DE CONSTRUÇÃO/MATERIAL DAS CASAS

$1.3 \%$

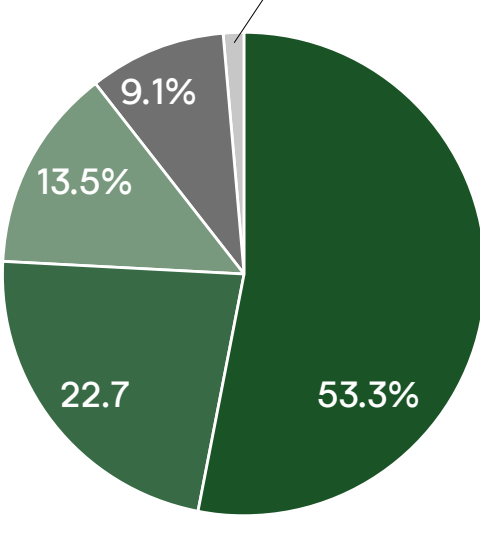

2019

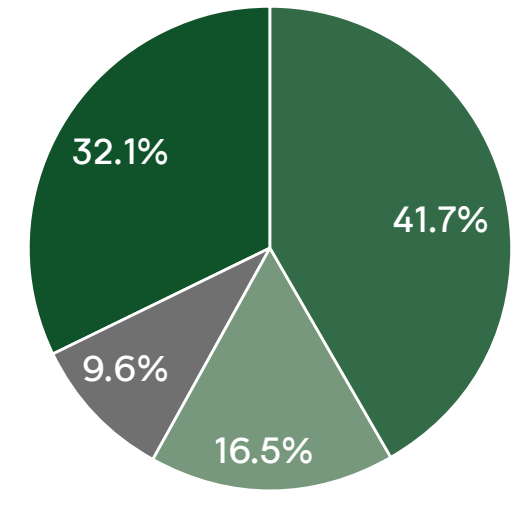

2021
Madeira

- Alvenaria c/ estrutura - Alvenaria s/ estrutura - Alvenaria e madeira

- Madeira e lona 
2. Outro dado importante é quanto à verticalização das casas. No censo de 2019 não existiu questão relacionada a isso, porque não fazia sentido para o contexto da ocupação naquele momento. Em 2021, com a observação de algumas construções com pavimento superior, acrescentamos uma questão a respeito, que revelou que das 448 casas, 21 são térreo + 1 pavimento, 72 são térreo + laje e 355 térreo sem laje (Tabela 4.2).

TABELA 4.2 - VERTICALIZAÇÃO DAS CONSTRUÇÕES

\begin{tabular}{lc}
\hline Térreo sem laje & 355 \\
Térreo com laje & 72 \\
Térreo + 1 pavimento & 20 \\
Térreo + 1 pavimento & 1 \\
TOTAL & 448 \\
\hline FONTE: Associação de moradores do Jd. da União, 2021. Elaboração própria.
\end{tabular}

3. Do total de famílias entrevistadas, apenas 17 casas não estão ligadas a nenhuma das três redes de infraestrutura: água e esgoto (SABESP) e energia (ENEL). A grande maioria (332) já estão ligadas às três redes. (Tabela 4.3)

TABELA 4.3 - CONSTRUÇÕES LIGADAS ÀS REDES DE INFRAESTRUTURA

\begin{tabular}{lc} 
Água, esgoto e energia & 332 \\
Somente água e energia & 80 \\
Somente água e esgoto & 4 \\
Somente esgoto e energia & 1 \\
Somente água & 2 \\
Somente energia & 12 \\
Nenhuma & 17 \\
TOTAL & 448 \\
\hline FONTE: Associação de moradores do Jd. da União, 2021. Elaboração própria.
\end{tabular}

4.A grande maioria, cerca de 419 das 448 famílias, têm a intenção de reformar e/ou construir. Dessas, 274 não têm previsão de início ou responderam que pretendem iniciar somente após a regularização fundiária. Isso demonstra duas questões: as melhorias urbanas entendidas como responsabilidade individual, afastada de uma discussão de políticas públicas. E, também, a insegurança da permanência como fator de decisão para as escolhas cotidianas dos moradores.

5.Por solicitação da nova Associação inseriu-se uma questão sobre a forma de aquisição do lote. Muitas pessoas se recusaram a responder a pergunta, mas mesmo assim 39 famílias responderam que foi por compra ou outro motivo e não via Associação de Moradores. O que comprova o processo de mercantilização de lotes.

6.Tentou-se também procurar entender a dimensão dos efeitos da pandemia, já que os territórios populares foram extremamente impactados. Sobre o contágio do vírus, 139 famílias responderam que tiveram um ou mais casos na família, o que corresponde a 217 pessoas. Dessas famílias, 6 relataram também que houve óbito.

7. Sobre a dificuldade na pandemia, somente 135 famílias responderam que tiveram condições de manter o isolamento social e para 170 pessoas (das 1.295 entrevistadas) a pandemia não afetou o emprego. Ainda sobre o emprego, 204 pessoas perderam o emprego durante a pandemia e 170 tiveram redução de renda/trabalho.

8.Dada a dificuldade de conter a ocupação das áreas verdes livres, a nova Associação tem buscado propor atividades e construir projetos para essas áreas. ${ }^{146}$ Para isso foi inserida uma questão sobre o interesse dos moradores em atividades dentro da ocupação. Das 1.295 pessoas entrevistadas, somente 467 responderam que não tinham interesse. Os demais elencaram temas como idiomas, alfabetização de adultos, esportes, dança, atividades físicas, cursinho e reforço escolar.

9.Uma questão que também foi inserida nesse novo censo foi sobre a religião. A grande maioria dos moradores se autodeclararam católicos (500), seguidos de evangé-

146 Essa é uma questão muito importante para a nova gestão, pois numa das últimas reuniões que tiveram com o movimento Luta Popular, para falar a respeito da regularização, foi bem enfatizado que quanto mais preservar a area verde, melhor os argumentos para negociar a permanencia. 
licos (339). Foi possível notar também a abertura de pelo menos mais 3 igrejas evangélicas na ocupação e algumas vezes que estávamos no Jardim da União, principalmente aos domingos, notamos a entrega de doações por parte de igrejas (Tabela 4.4 e Gráfico 4.3).

\begin{tabular}{lc} 
TABELA 4.4 - RELIGIÃO & \\
\hline Afro-brasileira & 6 \\
Católico & 500 \\
Ateu/Agnóstico & 6 \\
Evangélico & 339 \\
Espírita/kardecista & 9 \\
Outras religiões & 63 \\
"Sem religião & 215 \\
(mas acredita em Deus)" & 157 \\
Não responderam & 1295 \\
TOTAL & FONTE: Associaçãa de moradores do Jd. da Uniäo. 2021. Elaboracăoa próoria.
\end{tabular}

GRÁFICO 4.3 - RELIGIÃO

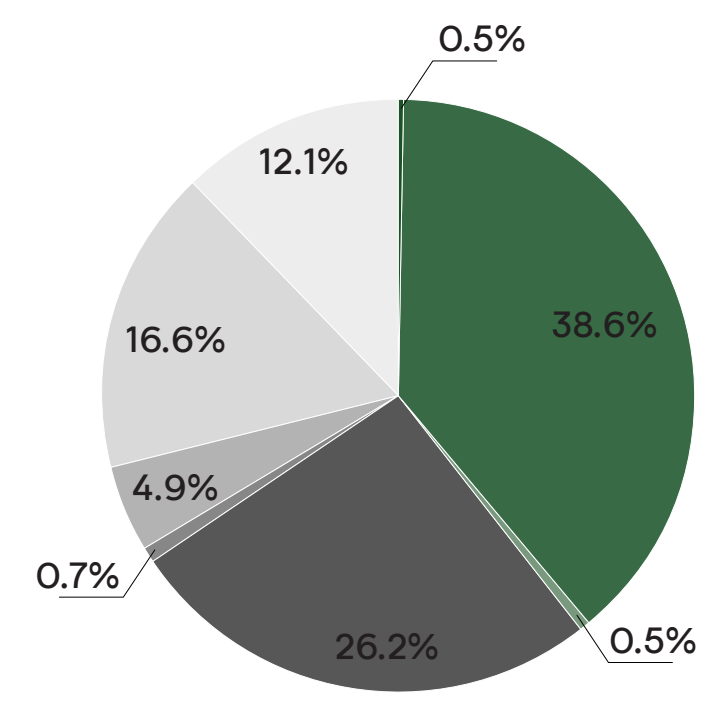

$$
\begin{aligned}
& \text { Afro-brasileira } \\
& \text { Católico } \\
& \text { Ateu/Agnóstico } \\
& \text { Evangélico } \\
& \text { Espirita/Kardecista } \\
& \text { Outras religiões } \\
& \text { Sem religião } \\
& \text { (mas acredita em Deus) } \\
& \text { Não responderam }
\end{aligned}
$$

10. Sobre os tipos de ocupação foi possivel verificar algumas mudanças. Ainda que o total de entrevistados não tenha sido o mesmo entre os anos de 2019 e 2021, o número de desempregados subiu de 152 para 220 e o de trabalho formal diminuiu de 238 para 163. Essas dificuldades enfrentadas na pandemia, como desemprego e redução da renda/trabalho, apareceram muito no novo censo (Tabela 4.5 e Gráfico 4.4 e 4.5).

TABELA 4.5 - TIPO DE OCUPAÇÃO/TRABALHO

\begin{tabular}{lcc}
\hline & 2019 & 2021 \\
\hline Trabalho Formal & 238 & 163 \\
Trabalho Informal & 293 & 214 \\
Empreendedor/PJ/MEI & 25 & 19 \\
Jovem Aprendiz & 6 & 2 \\
Desempregado & 152 & 220 \\
Aposentado & 27 & 15 \\
Outro tipo & 136 & 6 \\
Não se aplica & 542 & 656 \\
TOTAL & 1419 & 1295 \\
\hline FONTE: CPPATHIS, 2019 e, Associaçăo de moradores do Jd. da União, 2021.
\end{tabular}

GRÁFICOS 4.4 E 4.5 - TIPO DE OCUPAÇÃO/TRABALHO

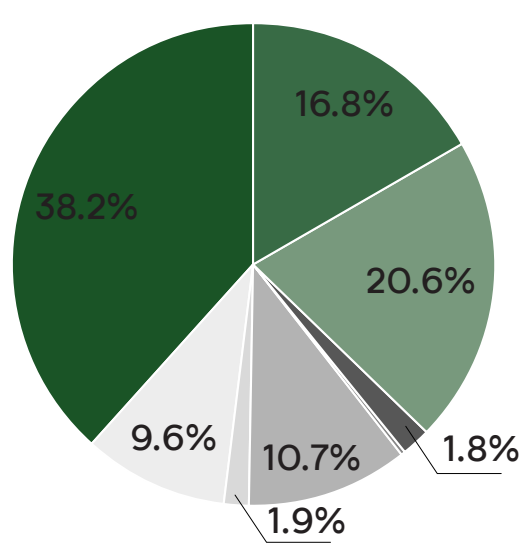

2019

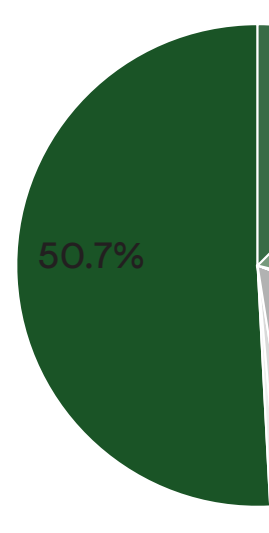

2021

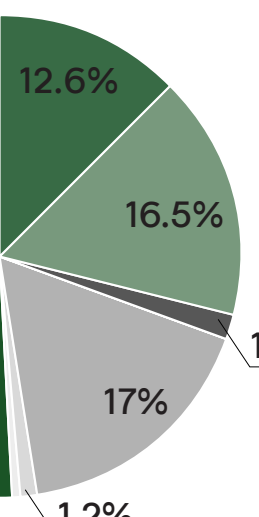

$1.2 \%$ 
Outro ponto notado, a partir das conversas durante a aplicação dos questionários ${ }^{147}$, foi que boa parte dos moradores optam por se referir ao Jardim da União por bairro e não mais por ocupação. Argumentam que após todas as mudanças ocorridas no Jardim da União, como a autourbanização, a construção das casas em alvenaria, a entrada das redes de infraestrutura mais recentemente (agosto de 2021) o início da pavimentação, já não faz mais sentido chamá-la de ocupação. Em certa medida, isso divide opiniões, pois conversando com outros moradores, principalmente quem está desde o início, a permanência em chamar de ocupação tem um papel político, pois procura demonstrar que esse território é fruto de intensa luta social para produção do espaço urbano.

Outra mudança, ainda mais recente (agosto de 2021), é o início da pavimentação de parte das ruas. A primeira a iniciar foi a rua da União e foi algo que não aconteceu através da Associação de Moradores, mas através da mobilização de alguns moradores que são articulados com políticos. A respeito disso, uma das membras da Associação disse: "aqui, a disputa é cotidiana”. Quando a Associação se deu conta já tinham iniciado e não estavam seguindo as distâncias definidas no Plano Popular, mas num "padrão prefeitura", que executa a rua com 5 metros de largura, sendo que no Plano existia a previsão de ruas de até 11 metros, como por exemplo a própria rua da União. Isso tem gerado diversas tensões e conflitos internos, como também as casas que já estão em alvenaria e avançaram os limites do lote.

Portanto, após as alterações ocorridas nessa nova fase é possível perceber que os moradores passam a conviver com os "paradoxos do desenvolvimento", com a entrada de novos atores e a constante disputa de "poder", a implementação da infraestrutura e a dificuldade dos moradores no pagamento das contas, conter (ainda que seja somente pelo convencimento) mercantilização dos lotes e a ocupação das áreas livres. Tudo

147 Participar da elaboração e aplicação do censo foi muito importante para mim. Senti que em cerła medida esłava mais proxima dos moradores, já que as questões impostas pela pandemia me trouxeram uma angústia em faze trabalho de campo sem estar constantemente no campo, ainda que tenha conseguido ir diversas vezes e sempre mantive contato com alguns moradores. mas não na mesma frequência e intensidade que gostaria. Com o censo tive a oportunidade de conversar com moradores que não conhecia e que nẫo xeram outros olhares sobre as dinâmicas experienciadas no Jardim da União. isso atravessado pelos conflitos, tensões e o desafio de engajar os moradores, pois a "luta não acabou". A trajetória do Jardim da União, como exposto aqui, é marcada por muitos acontecimentos, atravessamentos, conflitos, tensões e negociações cotidianas que contribuem, em certa medida, para delimitarmos como as cidades são produzidas, bem como entender os limites e as potências transformadoras presentes nas práticas populares dos que lutam pelo direito à cidade.
FIGURA 4.29 - Ocupação Jardim da União na fase do tijolo, construções em alvenaria, inclusive o barracão, e inicio da verticalização.

FIGURA 4.30 - Implementação de infraestrutura: redes de água, esgoło e energia elétrica. Inicio da pavimentação das ruas e instalação das placas Com os nomes das vias.
FONTE: Acervo da autora, 2021.

FIGURA 4.31 - Expansão de comércios e serviços: igrejas, lanchonetes, quitandas, salões de beleza, lojas de material de construção, padarias, pizzarias, bares e restaurantes.

FONTE: Acervo da autora, 2021,

FIGURA 4.32 - Folo aerea da ocupação Jardim da União realizada no

FONTE: Subprefeitura Capela do Socorro, 202

FIGURA 4.33 - Linha do Tempo sintese do Jardim da União.

FONTE: Elaboraçăo própria. 


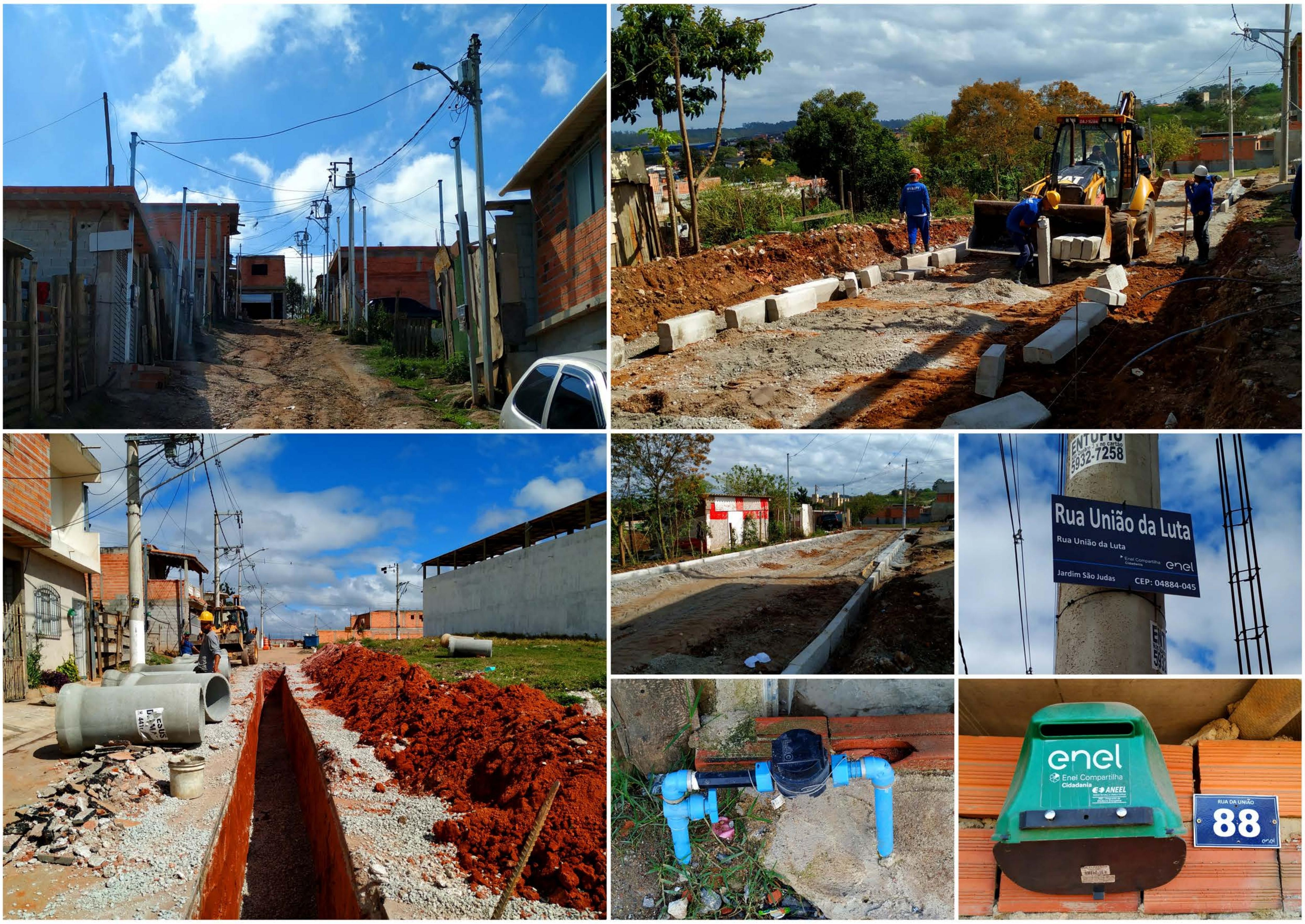




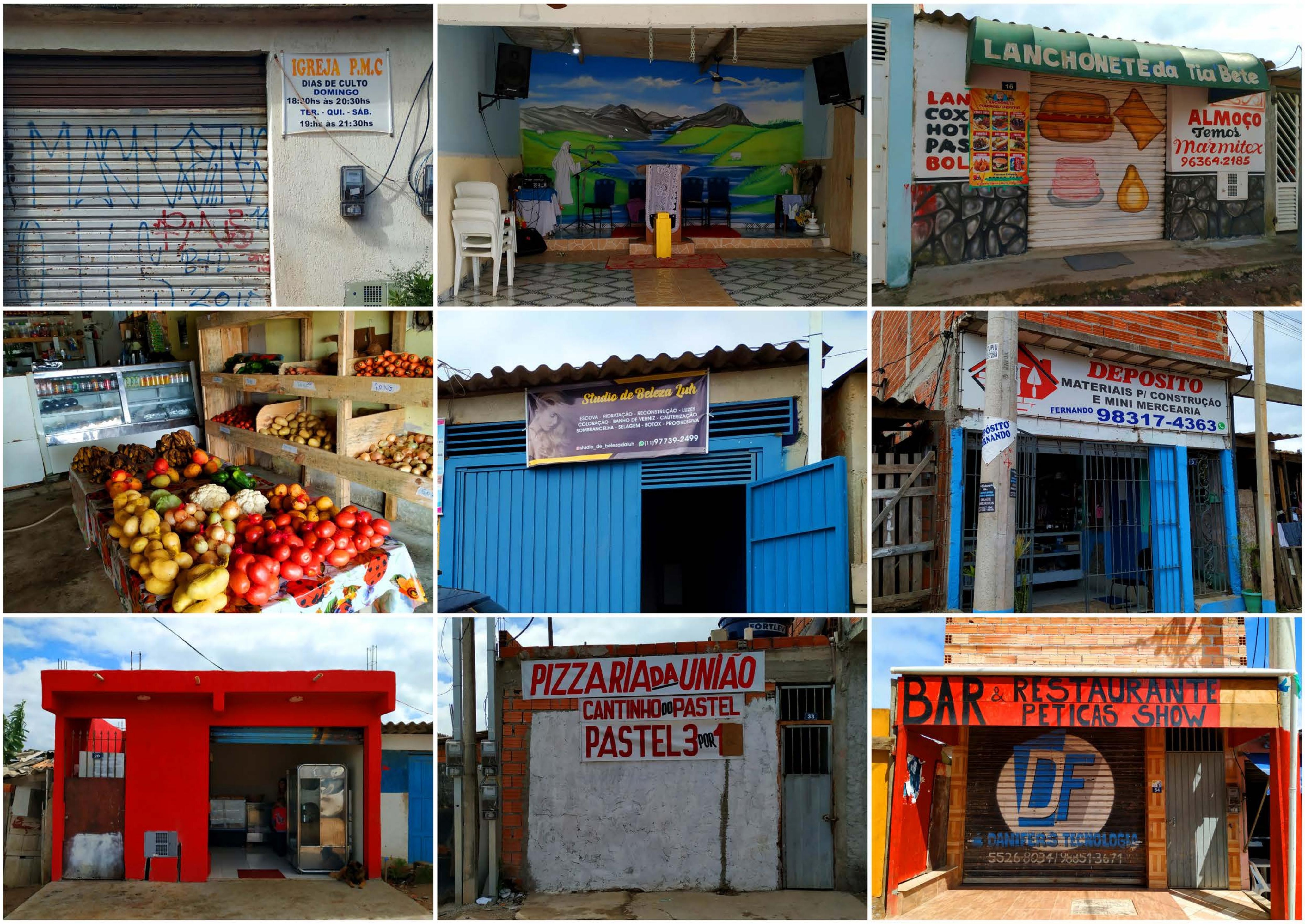




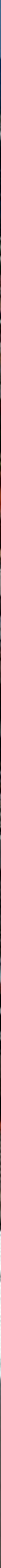


CONSIDERAÇÕES FINAIS:

na busca por uma possivel costura

DAS UTOPIAS

Se as coisas são inatingiveis...oral

Não é motivo para não querê-las... Que tristes os caminhos, se não fora A presença distante das estrelas! Mario Quintana
Mais do que concluir, busco costurar parte das reflexões realizadas ao longo da pesquisa que, para mim, foram verdadeiras chaves de entendimento sobre o que me propus a compreender ao longo do Mestrado. Foi, sem dúvida, um percurso de muito aprendizado e de ressignificações, justamente por isso acredito que se constituiu como um "novelo" no sentido de que minhas ideias durante um bom tempo me pareciam um emaranhado de fios enrolados, mas que ao escrever esse texto busco uma possível costura para os pontos abordados - e alinhavados - ao longo do trabalho.

Como dito, foi a partir da aprovação para participar da Economia de Francisco que surgiu a ideia de se fazer uma recuperação histórica da incidência das Comunidades Eclesiais de Base na consolidação de parte das periferias paulistanas. Tal recuperação não se constituiu como meu objeto de estudo, mas contribuiu, até mais do que eu poderia prever, para construção da argumentação proposta aqui. Da atuação das CEBs, me saltaram aos olhos: o trabalho de base, realizado no chão da realidade, a mobilização e articulação popular, a resistência ao regime político autoritário da época, bem como a importância dessa resistência no processo de reabertura política, as conquistas de direito e de melhores condições para os territórios que se deram a partir da reivindicação popular. Em resumo, a política presente nas práticas populares e o processo de construção da noção de que o morador de periferia tinha "direito a ter direito".

Com meu pé no chão da realidade das periferias paulistanas, pude realizar o campo desta pesquisa na ocupação urbana Jardim da União (SP). A partir de uma aproximação muito intensa e afetuosa e através da trajetória desta ocupação recente, 
procurei desvendar o processo de produção social do espaço urbano, que tinha como horizonte a seguinte pergunta: como se produz cidade hoje?

Com o trabalho de campo, pude resgatar parte das vivências experienciadas pelos moradores do Jardim da União, as suas práticas cotidianas e, a partir disso, depreender elementos que contribuem para o entendimento de como parte das periferias de São Paulo são produzidas na contemporaneidade, ainda que partindo de uma realidade situada, sem pretensões generalistas.

Para além disso, tinha muito claro, desde o início da pesquisa buscar a política presente nas ações cotidianas dos moradores que lutam pelo direito à cidade, ou ainda, como a política pode ser pensada a partir da base. No entanto, ao pretende estudar o tema da política, a violência se interpôs como uma temática imprescindível. Portanto, tratar do Jardim da União requer refletir sobre as relações entre política e violência já que a luta social presente na construção desse território, como foi possível constatar, é repleta de atravessamentos, conflitos, tensões, negociações, acertos que envolvem a relação de diferentes atores sociais. Dessa experiência me saltou aos olhos toda a potência criativa na luta cotidiana pelo direito à cidade, onde a ocupação é uma forma de vida, ou ainda, uma solução de vida (FISCHER, 1977), atravessada por diversas formas de violência.

O resgate das narrativas dos moradores mostrou não somente os sentidos das lutas políticas, a partir das experiências individuais e coletivas na construção da ocupação, mas também a violação de direitos e o quanto tais narrativas são ocultadas e invisibilizadas, sobretudo quando a cidade é abordada através da visão dicotomizada, na qual as periferias são definidas a partir do irregular e/ou informal.

A busca pelo sentido político presente nas CEBs e no Jardim da União tem como pressuposto que as experiências vividas são a base para as elaborações teóricas, em um movimento que não dissocia o pensamento teórico e a prática da ação, como também são a base para a real democratização das cidades. Identifica-se os potenciais transformadores, já que a prática popular é entendida aqui como indutora da construção de um projeto emancipatório. No entanto, reconhece-se também os limites que impedem a construção de outros mundos possiveis e da real democratização das cidades. É na contraditoriedade que se mostram os limiares de cidades outras.

Alinhavar esses dois pontos (CEBs e Jardim da União) foi importante para uma possível costura no sentido de buscar compreender os deslocamentos e as permanências ocorridos nas periferias a partir das décadas finais do século passado, ainda que esse não fosse um objetivo inicial da pesquisa. Como visto, as periferias paulistanas passaram por significativas mudanças que alteraram o cotidiano desses territórios, a maneira como são produzidos, bem como o modo como são figuradas no mundo público e os processos de subjetivação do mundo por parte dos seus moradores. Apesar de reconhecer que se trata de territórios muito heterogêneos, e longe de propor uma visão homogeneizadora sobre eles, ${ }^{148}$ pretendeu-se refletir sobre os deslocamentos que desencadearam inflexões nos cotidianos das periferias, e, ainda, algumas possíveis permanências.

Para além dos contextos históricos distintos, o primeiro deslocamento possivel de ser pontuado se refere aos atores sociais presentes no trabalho de base e as matrizes discursivas que contribuíram para a subjetivação de mundo dos moradores das periferias, já que essas são diferentes modos de abordagem da realidade, o que implica em diferentes significados. Dessa maneira, o trabalho de Sader (1988) contribuiu significativamente para compreensão do contexto em que os novos personagens entraram em cena, ou seja, quais eram os atores sociais e as matrizes discursivas presentes no período de surgimento e efetivação das CEBs. E foi a partir dos estudos de Feltran que apreendi as mudanças ocorridas nas décadas seguintes, ou seja, quando os mais novos personagens entraram em cena, como tenho nomeado aqui. Uma mudança, sem dúvida, lenta e gradual ao longo das décadas, que foi pouco a pouco renovando as matrizes discursivas e estabelecendo a coexistência

148 Reconhece-se que com o passar das décadas as periferias tornaam-se cada vez mais heterogêneas e com diferenciações internas, um dos motivos pelo qual utilizei, sempre que possivel, o termo no plural, pois "tento escapar, em cada página, das generalizações midiáticas e da formulação polarizada que compreende as periferias urbanas como submundos homogêneos e apartados das esferas sociais legitimas, como a familia, o trabalho, a religião, a moral e o Estado. Mais do que isso, tento afastar-me do olhar externo sobre elas e elaborar outra perspectiva de observação" (FELTRAN, 2011, p. 1-2). 
de outros regimes normativos. Como coloca Feltran (2011), 149 nos anos 1990, foram nas lacunas, antes ocupadas pela Igreja Católica progressista, pelos sindicatos e pela esquerda, que os novos atores e as matrizes renovadas se estabeleceram.

No Jardim da União, ainda que as mudanças sejam recentes, foi possível notar novas dinâmicas sociais após a entrada de atores sociais que não estavam presentes desde o início da ocupação. Hoje é possível perceber a capilaridade das igrejas, sobretudo as evangélicas, que se colocam como uma rede de apoio e solidariedade, principalmente em tempos de pandemia. Possível ver também o papel do mundo do crime enquanto mediador de alguns conflitos cotidianos entre moradores Associação de Moradores, passando a negociar com eles em sua busca por legitimidade. Percebe-se a paradoxal presença/ ausência do Estado na produção desse espaço urbano e o incentivo ao empreendedorismo popular, com programas como "Costurando pela Vida". Ao comparar a construção do território do Jardim da União com as periferias no contexto das CEBs possível dizer que não há instituições "por trás", como a lgreja estava naquela época. Ainda que tenha o apoio de movimentos como a Rede Extremo Sul e mesmo a Luta Popular, hoje o processo é mais disperso.

Falar sobre os novos atores sociais e as matrizes renovadas não significa afirmar que houve uma "substituição", já que sabidamente esses fenômenos são muito mais complexos, confluentes e coexistentes. Mas foi possível constatar que paralelamente à perda de espaço e de influência da Igreja Católica progressista e da Teologia da Libertação, consolidou-se crescimento da dimensão espiritual e ritualística de diferentes religiões (inclusive, da católica, via Renovação Carismática) em detrimento da ação social e política. Crescimento que se

149 "Os meninos do crime ativam, portanto, de esquina em esquina uma série de intersticios das relações entre práticas e discursos dos jovens, disputando as lacunas ocupadas antes tanto por familia e igreja, quanto por sindicatos, Comunidades Eclesiais de Base (CEBs) e partidos que se estabeleceram [...] durante os anos 1980. Sader (1988) encontrou em campo ação de base dos novos movimentos sociais como fonte de significação da vida de moradores jovens das periferias, cujas trajetórias haviam sido marcadas pelos deslocamentos dos anos 1970. Sua chave explicativa, dess significação, partida dos cotidianos e de sua politização. Não há dúvida de que, nos anos 2000, e a expansão do mundo do crime a que realiza a operação análoga, nas periferias de São Paulo" (FELTRAN, 2011, p. 171. grifos do autor deu pelo aumento de evangélicos, sobretudo dos neopentecostais, e pela expansão de discursos pautados na Teologia da Prosperidade. Da perda de influência do campo da esquerda e desmoralização de partidos progressistas, viu-se o avanço de forças conservadoras e partidos de direita. E, ainda, da estrutura sindical esvaziada pela reestruturação produtiva, que desencadeou mudanças no mundo do trabalho, viu-se a expansão do mercado informal e ilegal.

Alterações que impactaram as categorias fundadoras do território, já que na época das CEBs era caracterizada pela família (em geral, extensa), trabalho formal (operário), catolicismo, migração acentuada, que se amparavam em um discurso do sacrificar-se hoje para uma recompensa futura e de reivindicação de direitos, sendo que os nexos entre essas categorias possibilitaram a almejada ascensão social. A partir da década de 1990, houve um deslocamento para uma trabalho informal, expansão do mundo do crime, moral evangélica, empreendedorismo como alternativa, alinhado ao discurso do "aqui e agora”, os problemas entendidos em uma escala mais individual, assim como a superação das dificuldades a partir de uma noção de meritocracia, categorias amparadas pela razão neoliberal. E possivel pontuar um limite que se interpõe a partir da não construção de uma consciência social e política das assimetrias abismais presentes na sociedade, que se antes partia da denúncia dos fundamentos do sistema, hoje resulta em alternativas de vida muito individualizadas e heterogêneas, inclusive para membros de uma mesma família (FELTRAN, 2011).

Com a consolidação do estágio do capitalismo neoliberal, é possível pensar em pelo menos outros cinco deslocamentos, para além dos atores sociais, matrizes discursivas e categorias fundadoras:

1. mundo do trabalho: as periferias deixam de ser operárias e passam a ser informais (MARICATO, 2019), com intensa precarização do trabalho, aumento do desemprego e explosão da informalidade. Dessas mudanças se expande o mundo do crime, como alternativa de trabalho, como possibilidade de vida, que está de portas abertas àqueles que não teriam oportunidades em outro lugar, portanto se constituindo como meio de obtenção de renda, possibilidade de consumo e ampliação do status social (FELTRAN, 2018). 
2. Estado: Tanaka (2006) explica que a luta social engendrada pelos movimentos sociais estava amparada na ideia do Estado-provedor, ou seja, o Estado teria o papel de garantidor dos direitos sociais, de maneira justa e igualitária para todos, estando acima das demandas de classes. Ainda que a realidade fosse outra, dado o caráter de classe do Estado e a prioridade de atender aos interesses da reprodução do capital. Nesse contexto, já que não cumpria seu papel, os movimentos se colocavam em posição de antagonismo, pois reividicavam do Estado-provedor a universalização dos direitos. Com a inserção da ideologia neoliberal, há uma brutal ruptura com a concepção anterior, pois o Estado passa a ser entendido como incapaz de atender de forma universal a sociedade e por isso deveria focar suas ações onde teria maior resultado. Nessa concepção, o Estado deve ser mínimo, afastando suas responsabilidades sociais de garantidor de direitos transferindo-as para sociedade civil (DAGNINO, 2004).

3. acumulação capitalista: ainda que permaneça a concepção das periferias enquanto possibilidade de acumulação capitalista, Kowarick (1975) e Oliveira (2003 [1982]) demonstraram que esses territórios participavam da extração de sobrevalor na própria forma de urbanização (FELTRAN, 2014), enquanto que mais recentemente são vistas como formas flexíveis de acumulação do capital a partir da expansão de mercado de consumo e de circulação. ${ }^{150}$

150 Sobre a expansão dos mercados nas periferias, inclusive possibilitada pela ampliação de renda popular, do salário mínimo, do crédito dos programas de transferência de renda, Feltran fala, por exemplo, dos "mercados ilícitos como o narcotráfico, o contrabando e o roubo de carros. altamente lucrativos dada a muito menor mediação institucional. Os trabaIhos de Galdeano (2013) e Côrtes (2013) indicam como a lógica empreendedora atravessa "evangélicos", "bandidos" e atores estatais, transformando todos eles também em operadores de mercados, dos mais diversos. $A$ segurança privada, na rua Conde de Sarzedas em São Paulo, mas também os cultos midiáticos descritos por Birman (2012) e Machado (2012) sustentam-se em formas mercantis. A habitação social contemporânea é a ponta da operação de mercados financeiros transnacionais (Shimbo, 2013). Os garotos armados estudados por Lyra (2013) trabalham para o tráfico transnacional" (FELTRAN, 2014, p. 507). Nesse sentido, Feltran (2014) escreve sobre a aposta no dinheiro como mediação para o conflito social contemporâneo. O dinheiro passa a mediar, por exemplo, a relação entre o pastor. o irmão e o policial. 4.figuração: as ocupações deixam de ser "desejadas" e passam a ser "indesejadas". No período das CEBs eram "desejadas" - ou somente "toleradas" - pois foram necessárias no processo de expansão do capitalismo periférico ao participarem do rebaixamento dos baixos salários, em um contexto de industrialização e, nesse sentido, necessárias para a reprodução da mão de obra da indústria. A partir da década de 1990, as ocupações passam a ser vistas como ameaça ao modelo de concentração de terra tão característico e estrutural na sociedade brasileira - e os empobrecidos não acessam moradia, não somente pela exploração do trabalhador, mas também pela crescente valorização imobiliária. Portanto, passam a fazer parte das rotinas de expulsão. As ocupações são perseguidas e criminalizadas. Cria-se todo o imaginário e figuração pública de territórios de pobreza, violência, sem direitos, plausíveis, sob esse ponto de vista, de remoções forçadas. Não à toa as reintegrações de posse, extremamente violentas, com uso de força policial, passam a ser cada vez mais frequentes, inclusive como a ocorrida no Itajaí, descrito aqui em "massacre do itajai". 15

5.trajetórias: Grafmeyer (1995) afirma que nas décadas anteriores - contexto das CEBs - os deslocamentos espaciais podiam ser caracterizados como trajetórias de inserção, já que se tratava de um período de intensa migração, enquanto que no pós 1990 se tratou de trajetórias de exclusão, ou seja, moradores provenientes de remoções anteriores, como no caso do Jardim da União em que os moradores vieram do despejo sofrido no Itajaí, em um deslocamento que vai para "periferia da periferia" (MARICATO, 2013).

destacir a cal ainda que aconteça em plena pandemia e nesse sentido vale destacar a Campanha Despejo Zero. Sobre as reintegrações de posse, o Papa Francisco diz: "como dói escutar que os assentamentos pobres são marginalizados ou pior quer-se erradicá-los. São cruéis as imagens dos despejos forcados, dos tratores derrubando as casas, imagens tão parecidas às da guerra. "isso se ve hoje" (FRANCISCO, 2014, s/p.). Em convergencia, Silva (2020, p. 1414) diz que: "O evento da remoção, dada a violència empregada pelo aparato oficial de uso da força, gera efeitos destrutivos como a derrubada das por a a expulsăo imediata dos moradores. Evento frequentemente descrito por quem o viveu pela metáfora da guerra". 
6.conflito social: a relação entre periferias e o mundo público foi historicamente marcada pelo conflito (FELTRAN, 2010).

No contexto da efervescência dos movimentos populares na luta pela redemocratização, as periferias eram entendidas como o lugar de onde emergia inovação política e a expectativa era a ampliação democrática e a integração social dos "trabalhadores" 152 . No entanto, a partir dos anos 1990, a "renovação política" dos anos anteriores se fragiliza e as periferias passam a ser lidas como lugar da violência da pobreza, em que é preciso controlar os "bandidos", ou seja, o avesso da política democrática e não mais a extensão universal dos direitos (FELTRAN, 2014). Os efeitos desse deslocamento são vivenciados até os dias atuais, num processo de vinculação entre crime e ocupações urbanas, como demonstram muitas das falas dos moradores: "No Itajaí nós não dormia. A polícia perseguia a gente como se a gente fosse um bocado de ladrão, um bocado de bandido". $\mathrm{E}$, ainda, "aqui dentro não tem vagabundo, todo mundo aqui é trabalhador”. Há cada vez mais uma criminalização dos movimentos sociais e dos moradores de ocupações (que são silenciados, violentados e exterminados), deslegitimando-os e estigmatizando-os no mundo público, bem como o medo contra essa população é incentivado. Nesse sentido, há um deslocamento da maneira como as ocupações eram enquadradas, de "inovação política a integrar" para "violência letal a controlar", para serem figuradas como praticamente sinônimo de violência e pobreza. Há uma verdadeira

152 "Naquele perído, a violência não aparecia como categoria central nas análises das periferias, embora tanto a repressão policial ilegal quanto os grupos de extermínio e o narcotráfico já marcassem presença por ali [.... Talvez até porque essa violência, considerada subproduto direto da desigualdade. deveria ser suplantada pela democratização da cena polifica, que estava em pauta. [... Nos últimos anos, o cenário se inverteu. [.... Duas décadas de democracia institucional se passaram e hoje é a crueza da violência, tanto policial quanto aquela ligada ao trafico de drogas, o que chama atenção para as periferias urbanas" (FELTRAN, 2011, p. 17-18). criminalização ${ }^{153}$ e perseguição de maneira que os moradores das ocupações passam a ser caracterizados como "sujeito sem direito", inclusive sem direito à própria vida. ${ }^{154}$

Aposta na mídia que todas as ocupação tem marginal, tem ladrão. Ele não pode falar isso, porque nós aqui ninguém é ladrão, ninguém é bandido, tudo são pai de família, são morador, tem várias pessoa que precisa da sua moradia, ele tem que pensar isso na cabeça dele, que aqui ninguém é marginal, ninguém aqui é ladrão, nós tamo aqui nós precisa de um lar. Um aluguel hoje pra uma mãe que tem três quatro filhos, ninguém quer alugar a casa pra nós e um aluguel hoje é de oitocentos a mil reais. Quem é o pai de família que vai ter esse dinheiro pra alugar uma casa? Ninguém tem esse dinheiro. Nós ocupamo aqui porque nós precisa da moradia (Carla, CPPATHIS, 2019).

153 "São falas públicas e recentes do presidente eleito: [...] 'ações do Movimento dos Trabalhadores Rurais Sem Terra têm que ser tratadas como terrorismo'.. 'daremos retaguarda jurídica pra quem agir em defesa' (29/10/2018 - declaração para jornalistas em Esteio/RS durante campanha segundo reportagem do G1); 'os serviços humanos são um desserviço ao nosso Brasil' e 'a bandidagem vai morrer' (23/08/2018 durante comício de campanha em Araçatuba/SP segundo portal Noticias ao Minuto); 'eu sou favorável à tortura, o erro da difadura foi torturar e não matar... 'Pinochet devia ter matado mais gente .... a PM devia ter matado 1.0000 e năo 111 presos ... eu sou favoravel a pena de morte (23/05/M9 durante programa de entrevista ao da Comissão Pastoral da Terra (CPT) em maio de 2018 um da Comissáo Pastoral da Terra (CPT), em maio de 2018 um grupo armado do Araguia/PA recém despejadas de outro acampamento rural Os homens do Araguaia/PA, recen despejadas de outro acampamolto rural. Os homens criancas e as mulheres que casas, espancaram os adilos, aterrorizando as Crianças e as mulheres que em parte foram tambetm pisoleadlas e agredidas. tra os Movimentos Sociais no Brasi"” (DA.'BÓ DA COSTA, 2019, p. $218-219$ grifos meus).

154 “Já não se trataria da extensão universal dos direitos da cidadania (não se oferecem direitos a inimigos), tampouco da validade universal das garantias democráticas (a exceção è tolerada, pode mesmo se tornar regra, quando se trata de "defender a sociedade"). A conflitividade social brasileira exige, poranto, recortes populacionais aos quais se vai dirigir um repertório de modos de governo, que variam hoje da democracia substantiva ao extermínio. Esse mosaico de modos de gerir os pobres é radicalmente distinto daquele ancorado no mito da democracia racial, da primeira metade do século XX, ou nas subsequentes tentativas de inserção social do trabalhador migrante nas cidades, integração regional ou extensão regulada dos direitos sociais aos excluidos" (FELTRAN, 2014, p. 500). 
Como exposto, em decorrência dessas rotinas de expulsão, os empobrecidos vão se instalando cada vez mais em áreas periféricas, ou seja, na periferia da periferia (MARICATO, 2013), desprovidas de infraestrutura e distantes das ofertas de emprego. Nesse sentido, Silva (2O2O) faz um paralelo entre as periferias consolidadas (contexto das CEBs) e as ocupações recentes:

Os bairros de constituição recente e irregular, pelo próprio tempo de estabelecimento dos moradores no local, divergem em muito das periferias consolidadas e seus relatos "épicos" sobre neu proc (T) (a) ao processo de consolidação. luta por regularização fundiária, estabelecimento dos serviços urbanos basicos, lutas por equipamentos públicos, por exemplo, creches, escolas, postos de saúde. Tudo isso fruto de reivindicação e mobilização constantes e persistentes de seus moradores e moradoras. Hoje, nas franjas desses bairros crescem as ocupações recentes e em condições urbanísticas muito mais precárias do que as primeiras. Espaços mais distantes das ofertas de emprego e serviços a impor maiores dificuldades de mobilidade urbana cotidiana. precárias condiç̃oses de urbaidade, adensamento populacio.

$\mathrm{Na}$ grande maioria, as ocupações recentes se instalam em áreas ambientalmente frágeis, o que traz à tona a reflexão que o Papa Francisco (2015, p. 114) coloca de que "não há duas crises separadas: uma ambiental e outra social; mas uma única complexa crise sócio-ambiental". O Jardim da União demonstra bem isso, já que está localizado em área de manancial, ou seja, os espaços que "sobram" na cidade, em que, no contexto do neoliberalismo, a degradação socioeconômica se soma à degradação ambiental (DARDOT; LAVAL, 2016). O Papa Francisco (2015) traz uma visão sistêmica, a partir do conceito de ecologia integral, pois uma vez que "tudo está interligado" a salvaguarda ambiental não pode estar separada da justiça para com os empobrecidos e nem da solução dos problemas estruturais da economia.

Como visto no Jardim da União, para resistir às remoções forçadas, os moradores utilizaram algumas estratégias. Nesse sentido, vale destacar a elaboração e execução do Plano Popular, através da autourbanização, que deu início ao processo da construção das casas em alvenaria, que para além de melhora as condições cotidianas e ser uma maneira de provisão habitacional, tinha no horizonte a luta pela permanência, pois "a única maneira de permanecer era transformar a ocupação em bairro". O "plano", historicamente instrumento de poder, feito por aqueles que detém o "controle", ao ser popular permite, ainda que de maneira efêmera, que essa relação de poder se inverta e emerja da base.

Nesse sentido, se nas décadas passadas a autoconstrução foi entendida como participante da redução dos salários e da construção de um modelo de Estado neoliberal, hoje, além de ser solução para a necessidade do morar, é instrumento de luta pela permanência, pois quanto mais consolidada a ocupação mais difícil, pelo menos a princípio, sua remoção, como também pode ser entendida, como visto no Jardim da União, como estratégia para negociação e reivindicação de direitos (SANTO AMORE et al., 2O21). ${ }^{155}$ Sendo assim, esse ponto interessa muito à pesquisa, pois quando me refiro às ocupações como resistência, significa dizer que fazem parte de um processo de resistência frente às violências e privações que seus moradores sofrem no seu dia a dia.

Outras estratégias também se somam a essa como, por exemplo, na fase inicial da ocupação, a construção dos barracos bem próximos, o bater panelas sob qualquer ameaça, a corrente humana quando os policiais entravam na ocupação, rodízio de funções para garantir a sobrevivência de todos, não sair dos barracos em caso de uma reintegração de posse, já que achavam "que não ia derrubar com as crianças dentro né". E, ainda, as interações com o Estado onde expressam suas demandas e pressionam o poder público a negociar: as

55 “A autoconstrução como instrumento de luta politica no contexto das ocupações urbanas é um dos fatores que potencializa a possibilidade de posse do terreno ocupado. A moradia de alvenaria é um indicativo da premente necessidade dos ocupantes. Aos olhos dos agentes públicos que determinam a reintegração de posse, este é um fator que pode pautar a sua decisão, favorecendo para a permanência no local. Caso a decisão seja pela reintegração de posse do imóvel, um maior número de construções em alvenaria dentro do terreno ocupado gera uma dificuldade maior para a sua realização. Além da dificuldade óbvia para remoção de uma moradia de alvenaria comparada com outra de madeirite ou de lona, situação característica das ocupações urbanas em seus primeiros momentos, a remoção de uma casa de alvenaria aumenta o ônus politico da ação de reintegração de posse, essa remoção pode comover inclusive aqueles que, a principio, são contrários a esse tipo de ação polifica, sendo que a casa de alvenaria expressa uma grau de dificuldade maior para sua construção. A partir desses fatores apontados acima, acredito que a autoconstrução é uma situação que se adequa ao sucesso politico de uma ocupação urbana" (LOURENÇO, 2O15, p. 113-114). 
passeatas, os atos, as manifestações na subprefeitura ou no $\mathrm{CDHU}$, e as demais formas políticas que demonstram a capacidade de mobilização dos moradores. Segundo Dal'Bó (2019), o limiar dessas resistências políticas, que tenho nomeado de estratégias, na luta pela permanência passa à dimensão dos próprios corpos dos moradores, ao colocar a integridade de cada um em risco. Nas palavras do autor:

a iminência da violência do Estado contra as pessoas é o elemento que explica a produção do espaço neste momento em que nenhuma lei, instituição ou avanço normativo constitucional parece ter qualquer efeito garantido sobre a realidade (DAL'BÓ DA COSTA, 2019, p. 115).

Na interação estado-sociedade (ABERS; SERAFIM; TATAGIBA, 2014) vale destaque a atuação da Rede Extremo Sul, que colaborou na organização e mobilização dos moradores desde o Itajaí. Penso que essa rede pode ser considerada, nos termos de Gohn (2017), como sendo parte dos "novíssimos movimentos sociais", conceito que atualiza os "novos movimentos sociais", cunhado por Sader. A autora fala que o primeiro ciclo de emergência periférica, no contexto das CEBs, é composto por militantes, enquanto que no segundo, onde a ocupação Jardim da União se enquadra, é composto por ativistas. Eis mais um deslocamento: da militância ao ativismo (MORAIS, 2018).

De acordo com Gohn (2017) e Morais (2018), alguns pontos diferenciam esses dois ciclos de emergência política periférica:

(1) enquanto os militantes buscavam construir a noção do "direito a ter direitos", os ativistas buscam acessar os direitos constitucionais - alcançados, em parte, pelos militantes mas que não foram garantidos a todos;

(2) a militância era constituída por uma estrutura mais rígida e hierárquica, enquanto que no ativismo esta se torna mais horizontal, fluída e orgânica;

(3) os militantes tinham pautas mais claras e objetivas, que contemplavam o universal, como por exemplo melhorias urbanas, e forte alinhamento com o tema da luta de classes, enquanto que os ativistas possuem pautas mais autocentradas, particulares e até mesmo imediatas, com temas ligados às questões identitárias e culturais como gênero, raça, etnia e juventude;
(4) o "sujeito coletivo" da militância era unido por ideologias e ideias políticas que muitas vezes girava em torno dos partidos e sindicatos. Já no ativismo há uma pluralidade de movimentos, em que o "sujeito coletivo" é fragmentado e por isso de difícil definição, situando-se fora dos partidos e sindicatos, inclusive, muitas vezes, rejeitando-os.

Sobre esse último ponto, D’Andrea (2013) diz que enquanto no primeiro ciclo existia a presença de atores "externos" às periferias, como membros da igreja, dos partidos, dos sindicatos e da academia, hoje cada vez mais, tanto ação quanto reflexão, partem dos próprios sujeitos periféricos. Apesar de trazer as diferenciações dessa maneira, é importante dizer que não há uma dicotomização entre os dois ciclos, mas a ressignificação das lutas sociais presentes nas periferias, fruto do seu momento histórico (MORAIS, 2018). Portanto, essas divergências não são estanques, mas os ciclos que transmutam um no outro (NEVES et al., 2018).

Arrisco dizer que a Rede Extremo Sul se enquadra nesse segundo ciclo emergência, já que: ${ }^{156}$

(1) tinha como bandeira de luta a garantia dos direitos constitucionais: "exigimos a construção de um projeto participativo e popular de reurbanização de nossas comunidades que una a preservação ambiental à garantia de moradia e de outros direitos sociais assegurados a nós, pelo menos na teoria, pela Constituição"

(2) movimento com estrutura organizacional fluida: "outro motivo importante é que somos contra a profissionalização da militância, que gera no interior do movimento desconfiança, disputas de poder, acomodação, hierarquias, e também a dependência e a perda da autonomia de decisão e de ação [...] O caráter orgânico desse processo faz com que a dimensão da formação política seja estratégica, de modo a fazer com que os processos de luta e de organização sejam levados adiante pelas próprias referências das comunidades";

156 Todos os trechos a seguir entre aspas foram extraídos do site da Rede Extremo Sul. Disponivel em: hittps://redeextremosul.wordpress.com/. Acesso em 28/08/2021. 
(3) para além de temas ligados ao direito à cidade, tinham como pauta a denúncia da violência do Estado, a construção de iniciativas de arte e cultura a partir dos sujeitos periféricos, como também temas como racismo e juventude: "fortalecer o combate à violência que permanece - contra os negros e contra a periferia. A violência tá lá disfarçada na ideologia que não existe mais racismo e em todo tipo de idéia preconceituosa, que discrimina e agride cada um mas também tá escancarada no encarceramento em massa e no genocídio da juventude";

(4) e se recusam a fazer aliança com "politiqueiros", porque defendiam que "as mudanças que são necessárias para que possamos ter uma vida digna não vão vir pelas urnas, mas sim do povo unido, organizado e lutando." Se definiam como uma "organização autônoma do povo da periferia, sem depender de politiqueiros, nem de patrões, nem da migalha de quem quer que seja. Propomos a união das quebradas e a luta direta como meio de melhorarmos a nossa condição de vida, e combatermos as formas de opressão e de exploração que sofremos todos os dias".

A Rede Extremo Sul procurava construir uma frente anticapitalista, pois se colocavam "contra as diversas formas de opressão e de exploração que movem o capitalismo". Quando iniciei a pesquisa eu apostava nisso, muito motivada pela minha participação na Economia de Francisco. No entanto, com o desenvolvimento da pesquisa e as novas dinâmicas no Jardim da União. comecei a elaborar melhor as contradições inerentes mesmo em movimentos e/ou organizações espontâneas que a princípio buscam outras práticas possíveis. Por exemplo, a permanência ao longo das décadas de valores capitalistas, como a centralidade da propriedade privada, mesmo na luta social pela terra, que tem um componente político a mais (do que outras lutas) por ferir um valor capitalista que é a propriedade privada ${ }^{157}$.

157 Luiza Erundina diz: “(...) porque você veja bem, o que que é propriedade privada, sobretudo da terra no sistema capitalista? E um pilar né? Então qualquer luła que ferisse, que ameaçasse lesse pilar] mexia na estrutura...então tinha uma dimensão politica...né? Na sua essência, na sua substância. Diferente, portanto, da luta por creche, por hospital, da luta por astalto...tamberm é uma luta por direitos sociais, mas não tinha um componente politico como essa luta Lpela posse da terra], porque ela mexia com um valor capitalista. um pressuposto do sistema capitalista que é a propriedade privada da terra" (FELTRAN, 2003, p. 30).
No entanto, os moradores, que a princípio estariam ameaçando um valor capitalista, engendram essa luta que muitas vezes acaba por limitar-se à conquista da "casa própria", ou seja, um bem de consumo inserido no modelo da propriedade privada e individual. Falas como "nós não tamos aqui pra poder invadir, nós tamos aqui pra comprar" e "queremos pagar pela casa" demonstram que a aquisição é legitimada via consumo, que no fim informa que tais bens (como o teto, a terra) são vistos como mercadoria e não direito constitucional, muito menos como bens comuns. É uma mentalidade capitalista introjetada, que ganha mais aderência com discurso neoliberal da meritocracia, do individual e do estado mínimo.

No fim se luta pela regularização fundiária, ainda que se coloque "contra" a propriedade privada, pois esta finda o conflito fundiário, garantindo a permanência ao afastar a ameaça da reintegração de posse. Já que a cidade é produzida pela lógica da propriedade, a regularização permite não somente a segurança jurídica da permanência, mas também simbólica/ emocional, do "direito à memória" (BOSI, 1994), de construir vínculos sem o receio de a qualquer momento ser removido, pois o enraizamento permite a constituição de uma experiência situada (SILVA, 2O2O). Como demonstrado nas falas dos moradores, possibilita "dormir tranquilo", sem o medo da "polícia matar nós tudo", entrar e "quebrar tudo e todos" e no "outro dia trabalhar com sono", assim como a garantia de não perder lugar onde "você cria toda sua história, cria sua vida, os seus filhos, tudo, tudo, tudo". 158

58 "E importante ressaltar que, apesar do caráter flagrante de insurgência, ransgressão e radicalidade das ações dos grupos de sem-teto, noła-se que. sob determinadas demandas, as suas ambições circunscrevem-se a atingir patamares bastante convencionais no que tange à propriedade da moradia dentro dos marcos instituídos pelo sistema capitalista e dos valores individuais, privados e pequeno-burgueses. A grande maioria dos debates, reflexões e demandas dos grupos de sem-teto limita-se a demandar moradia enquanto bem imóvel a ser financiado em moldes de propriedade privada e individual. Um número bastante reduzido de experiências e lideranças têm proposto o debate e lançado o desafio da produção de moradia como bem de propriedade comum, coletiva, comunitária ou pública, ou, ainda, avaliado outras formas de pressionar o poder público por politicas mais diversificadas, que considerem formas de produção da moradia (ou reforma de imoveis existentes) em novas bases" (FERRARA; GONSALES; COMARÚ, 2019, p. 825). 
Assim, destaco a permanência da ideologia da casa própria, já sinalizada por Bolaffi na década de 70 , como sendo a principal aspiração da população urbana brasileira, onde sua aquisição é considerada uma evidência de sucesso (BOLAFFI, 1982 [1975]). Já Lago (2019), demonstra que a propriedade privada da terra é condição primeira para a mercantilização da cidade e a ideologia da casa própria está introjetada na mentalidade da população brasileira como se fosse a única forma segura de garantia de uma habitação, ainda que essa segurança nem sempre se confirme. A centralidade da casa própria ganhou ainda mais impulso nas últimas décadas, amparada nas matrizes discursivas do neopentecostalismo e do empreendedorismo, como revela a autora:

A instância coletiva como instância de poder para garanti direitos tem uma presença tímida na nossa cultura política. Qualquer forma de direito coletivo de posse é vista a princípio, como alto risco. A crença na estratégia individual ou familiar para alcançar uma vida melhor se difundiu no pais nas três últimas décadas, impulsionada pela teologia da pros peridade e pelo empreendedorismo. A aposta em estratégia coletivas está condicionada à formação de identidades coletivas em torno de interesses e projetos comuns, forjados, seja no lugar de trabalho, seja no lugar de reprodução da vida (LAGO, 2019, p. 40).

A segurança da permanência, ao garantir estabilidade, permite aos moradores, inclusive, utilizar os parcos recursos na melhoria de suas casas, o que também demonstra o afastamento da reivindicação de direito, já que as melhorias habitacionais deveriam ser parte de políticas públicas e não responsabilidade individual. E bem comum moradores relatarem as inseguranças em realizar reformas, melhorias em suas habitações, por ter medo de serem removidos. Até mesmo a decisão de construi ou não em alvenaria é atravessada por essa insegurança da permanência e, assim, muitos continuam em condições difíceis da moradia em madeira, numa gestão diária do viver em risco. (KOWARICK, 2009)

A ideologia da casa própria e a luta pela regularização fundiária podem ser entendidas também como limites para a real democratização das cidades, já que no horizonte está posto teto terra enquanto mercadoria. Isso porque a produção do espaço urbano está inserida no modo de produção capitalista - portanto, cidade produz ocupação - o que ocasiona bloqueios de emancipação (DAL'BÓ DA COSTA, 2019). Nesse sentido, a fala de Fernanda é bem impactante e ilustra esses limites:

Então, tinha cooperativa, tinha a creche comunitária, biblioteca, tinha o pessoal da reciclagem, das meninas da costura. Então, tinha tudo isso. Só que dá pra você dar autonomia, dá pra dar essa essa oportunidade de trabalho muito próximo a casa ou dentro da própria casa, só que contrapartida, você tem um mundão lá fora né? Então como que você mantém isso duranmundán te multo tempo? Q do coletivo, a base da froca, enfin, que, por exemplo, você vai trabalhar hoje na cooperativa que tambem e aqui dentro, e seu filho vai ficar aqui na creche comunitária. E é isso, não tem condições de segurar muito tempo, porque em volta você tem capitalismo assim arregaçando, fazendo as pessoas pensarem: "não, eu preciso de muito mais, eu preciso de um trampo, de um trabalho." Então, durante determinado período isso funcionou e muito, muito, muito (Fernanda, CPPATHIS, 2019).

Iniciativas como as cooperativas do Jardim da União, que podem ser entendidas como caminhos possíveis para uma nova economia, não vão para frente porque em volta se tem o "capitalismo arregaçando" e a "ilha construída" acaba cedendo lugar porque a mentalidade do conquistar "sempre mais" vai ganhando força. A mudança de mentalidade é um grande desafio para a construção de novos mundos possíveis, não mais pautados pelos valores capitalistas, pois, segundo o Papa Francisco, é urgente a necessidade de mudança de mentalidade que resulte em práticas transformadoras.

Mas, dialeticamente, digo também que a ocupação produz cidade, já que tanto na época das CEBs quanto a partir do Jardim da União, a ocupação pode ser entendida como uma forma de produção da cidade (MAUTNER, 1999) e daí se revela sua potência transformadora. A frase "nós fizemos um pedaço de cidade" de uma moradora ao ver a foto aérea do Jardim da União após a autourbanização é muito potente, já que a produção desse espaço é fruto de muita mobilização e densidade política.

Em ambos os contextos, o início da ocupação foi marcado por condições mínimas de habitabilidade, com espaços em constante formação e transformação, mas que, a partir da convivência e da autorganização, os moradores vão buscando suprir as necessidades mais básicas, simples e imediatas ao amenizar as dificuldades cotidianas. O enfrentamento dessas dificuldades muitas vezes se dá a partir da ajuda mútua, da reciprocidade e das práticas solidárias e, assim, os moradores vão se constituin- 
do enquanto sujeitos coletivos. A construção, por exemplo, de espaços comuns demanda esforços individuais que produzem uma coesão interna fundamental para a construção da noção de coletividade (BASTOS et al., 2017). Algumas falas evidenciam isso: "sempre tem o buraco na cerca pra salvar" e " aqui um lugar muito bom, as pessoas são unidas, né? O que a gente puder ajudar a gente ajuda".

O Papa Francisco fala que no mundo atual, marcado pela globalização da indiferença e cultura do descarte, a solidariedade por si só é um ato transgressor ao sistema econômico vigente. Nesse sentido, não deve ser entendida como gesto esporádico, mas como ação transformadora. E como o Papa vem da Teologia do Povo, na qual o povo é identificado com um sujeito coletivo único ou ainda sujeitos sociais e políticos, ele aposta nas mudanças que partem da mobilização popular, estruturada por uma cultura comum, já que, nas suas palavras: "os pobres não só padecem a injustiça, mas também lutam contra ela!". (FRANCISCO, 2014, s/p.)

Vale destacar que o processo de mobilização passa por períodos de maior e menor intensidade. É comum que após o êxito,

a partir de uma intensa luta coletiva, as demandas tomem um caráter às vezes mais individual. Isso é percebido em diversos momentos na trajetória do Jardim da União, pois, apesar dos esforços constantes da Associação de Moradores, ora estão mais mobilizados e ora menos. Se considerarmos as "fases", foi possível notar que na "fase da lona" os moradores estavam mais mobilizados e utilizavam mais de práticas solidárias para a construção do território. Já na "fase do tijolo", passa a ser um combinado entre trabalho próprio e contratado e parece que quanto mais consolidada a ocupação, mais dificuldade em manter o engajamento dos moradores, sobretudo com as novas dinâmicas: inserção de novos atores sociais, dificuldades perante a pandemia, mercantilização de lotes e rotatividade dos moradores sem o "histórico de luta", inclusive com alguns moradores não querendo mais que chame de ocupação e sim de bairro.

Outras duas permanências possíveis de serem pontuadas que se constituem também como potencialidades - são: (1) a forma ocupação como lugar de reivindicação de direitos, para além da casa, como demonstra Raimundo, "na luta por moradia se tem outras lutas também que nós fazemos no dia a dia”, que tem no horizonte a busca por uma cidade mais igualitária e jus- ta; (2) atuação dos moradores como protagonistas políticos que ao engendrar lutas sociais vão construindo uma consciência crítica. Teresa, conta que "tava muito difícil pagar aluguel pelo o que eu ganhava, e daí entrei no mundo da luta que é ocupação", e nesse sentindo a necessidade da casa foi seu ponto de partida para o entendimento da realidade de espoliação urbana a qual ela e sua família estão submetidas diariamente, pois participar do movimento a emancipou. Portanto, a permanência, ao longo das décadas, das periferias como forma de acessar e produzir cidade demonstra que estas não são construídas desde sempre para oferecer espaços adequados para todos, bem como as políticas públicas continuam a ser insuficientes, ineficientes, inadequadas e excludentes.

É potência transformadora também porque se constitui como processo que parte da base com a constituição do sujeito coletivo, social e político. Como bem coloca o Papa Francisco (FRANCISCO, 2O2Oa, p. 169), "quando se trata de recomeçar, sempre há de ser a partir dos últimos", a partir do sabor e saber locais, já que sem o protagonismo dos empobrecidos não há fraternidade universal. Portanto, em um movimento "de baixo para cima", em que "não pensemos por eles, pensemos com eles. E deles aprendamos a fazer progredir modelos econômicos que beneficiem a todos". (FRANCISCO, 2O2Ob, s.p., grifos do autor) ${ }^{159}$

Dessa maneira, as estratégias travadas pelos moradores do Jardim da União podem ser lidas como potências já que se tem a busca pela apropriação do espaço urbano e, nesse sentido, se tem, ainda que efêmero, o direito do uso se sobrepondo ao direito à propriedade privada, no sentido lefebvriano. Para além da habitação, as ocupações têm o espaço da festa, do convívio, da coletividade, pois ocupação produz cidade, porque a festa é tão importante quanto a luta. Por isso, digo que são espaços

159 Em 202O, contexto de pandemia, o Papa Francisco (2020c, s/p.) escreveu uma carła aos movimentos populares, que diz: "Vocês são para mim, como thes disse em nossos encontros, verdadeiros poetas sociais, que a partir das periferias esquecidas criam soluções dignas para os problemas mais urgentes dos excluidos. Quero que pensemos no projeto de desenvolvimento humano integral que almejamos, centrado no protagonismo dos Povos em toda sua diversidade e o acesso integral a esses três T que vocês defendem: terra, teto e trabalho. Espero que este momento de perigo nos tire do piloto automático, agite nossas consciências adormecidas e permita uma transformação humanista e ecológica que coloque fim à idolatria do dinheiro e coloque a dignidade e a vida no centro". 
para além da resistência, mas da potência e das possibilidades, pois têm muito a ensinar sobre outros modos de morar, de se relacionar, de viver o território e do saber/fazer popular. Portanto, o direito à apropriação como inerente ao direito à cidade. Assim como Harvey (2013), concordo com Lefebvre, quando pontua que a revolução tem de ser urbana, já que pensar no futuro da nossa sociedade passa necessariamente pelas cidades onde vivem $85 \%$ da população brasileira. É na vida cotidiana urbana que vemos a dimensão das questões sociais sentimos os efeitos dessa economia da morte e da exclusão.

No entanto, não livre de contradições, pois tais territórios são vistos também como possibilidades de expansão do capital, em um processo no qual:

[... o resultado da produção de valores de uso, primeiro através de trabalho individual (que produz moradias), e depois através de trabalho coletivo (infraestrutura provida pelo Estado) transforma-se em valor de troca, constituindo-se em porcões definidas (como propriedades) de espaco urbano consolidado

controlado diretamente pelo capital (MAUTNER, 1999, p. 258).

Justamente porque as ocupações podem ser lidas como potência transformadora que são recorrentemente criminalizadas, perseguidas e despejadas, por isso aqui há a defesa de que ocupar se constitui como ato político, transgressor, insurgente, contra-hegemônico e de resistência. ${ }^{160}$ É resistência porque a disputa pelo solo urbano é - e sempre foi - muito acirrada e porque demonstra o não cumprimento da função social, que por sua vez impõe limites ao direito de propriedade. Tanto é que desperta a reação conservadora que resulta em despejos forçados e, portanto, os moradores das ocupações resistem à

160 "O simples desejo de existência de uma cidade menos segregada, quando colocado em prática através de uma ação radical de ocupação organizada para fins de moradia, produzirá a partir deste ato de resistência uma jâ esperada reação imediata das forças dominantes que produzem as cidades, tendendo a encontrar e acionar as rotinas e expedientes existentes para expulsão desła população, ou então, quando tais rotinas existentes não forem suficientes, criar-se-ão novas rotinas para tais fins. Neste momento de conflito, a tentativa de construção da cidade como um espaço menos segregado será bloqueada pela reação de conservação das forças vigentes e legitimadas na produção das cidades. A reação e o bloqueio, e a forma como eles se fazem, poder ser eles mesmos reveladores de uma realidade atual das cidades (DAL'BÓ DA COSTA, 2019, p. 34). expulsão ao lutar pela permanência. ${ }^{161}$ É resistência a um sistema econômico injusto e excludente por natureza, no qual tudo se torna mercadoria, e, portanto, a necessidade de se pensar em outras economias. Daí a importância de movimentos como a Economia de Francisco. Resistência a uma cidade segregadora que na disputa por localizações expulsa os empobrecidos para os locais que sobram na cidade. As ocupações ao existirem na cidade instintivamente resistem, no sentido do existir e resistir, como duas coisas muito relacionadas, culminando em um reexistir (FUKS, 2019). Reexistir não como atos esporádicos, mas carregando em seu cerne um potencial transformador por cidades democráticas, justas, emancipatórias, construídas a partir de uma "Economia de Francisco", em que a terra e o teto não sejam entendidos como mercadoria, portanto rumo à desmercantilização dos bens essenciais à vida.

A desmercantilização da cidade só pode ocorrer através de outras formas de propriedade da terra e de apropriação urbana do espaço. Uma vez que a propriedade privada da terra que se conhece hoje foi inventada, é necessário pensar em novas formas de vínculos que sejam ligados às práticas socialmente consistentes, formas alternativas não alienadas de ser e viver, em resistência à privatização da cidade e da vida. Esse pode ser um caminho para valorização do uso dos bens comuns e reapropriação urbana em contraposição à apropriação privativa e predatória do mercado.

Assim, a trajetória do Jardim da União, enquanto construção coletiva baseada na solidariedade, se coloca como alternativa da produção desigual das cidades. E, apesar das contradições inerentes, pode ser lida a partir da Economia de Francisco como um apontar de possíveis caminhos para o processo de desmercantilização da cidade, na qual a busca ideal seria pela desmercantilização da existência, em que as pessoas não mais lutem pela sobrevivência, mas tenham o direito de viver asse-

161 É resistência ainda que tenham sofrido despejo, como no caso do Itajai, já que "podemos dizer que a resistência também aconteceu de diferentes formas, ora mais e ora menos explicitas. Observamos a resistência, por exemplo, na reivindicação discursiva de alguns moradores e moradoras reivindicando para si de um lugar de protagonismo nos desdobramentos e lutas posteriores ao evento da remoção, visando obter a reparação do fato. De outro modo, a resistência aconteceu na mobilização politica na qual se engajaram moradores e moradoras, descobrindo, ao longo do processo, um destino comum e produzindo uma experiência coletiva" (SILVA, 202O, p. 1421). 
gurado. Essa é a leitura que proponho para a trajetória dessa ocupação recente, buscando superar visões dualistas estigmatizadas das formas de produção da cidade.

A articulação do duplo movimento entre a organização e mobilização popular (trabalho de base) e a construção de uma nova economia se constituiu para pesquisa como possibilidade de explorar possíveis alternativas emancipatórias aos processos de mercantilização do urbano e às imposições da economia de mercado na sociedade brasileira contemporânea.

Com pé e fé na caminhada busquei trazer toda a potência existente nas práticas populares, para confrontar o presente $e$ ampliar o horizonte dos possíveis. Espero que esta Dissertação de Mestrado se constitua como vento de esperança para os tempos tão sombrios e dramáticos que estamos enfrentando, no país e no mundo.
QUADRO 5.1 - PERMANÊNCIAS

\begin{tabular}{ll}
\hline Limites & Centralidade da casa própria \\
& Luta pela regularização fundiária - propriedade privada \\
& Periferia como fronteira de expansão do capital \\
Inserir-se no modo de produção capitalista (hoje no estágio neoliberal) & Melhorias habitacionais como responsabilidade individual e não como \\
& parte de politicas públicas \\
& Alternância entre mobilização e desmobilização popular \\
\hline Potencialidades & Periferias/ ocupações como uma forma de produção social do espaço \\
& Constituição de sujeitos coletivo social e politico \\
& Ajuda mútua, reciprocidade e solidariedade \\
como transgressores ao sistema & Construção de consciência critica a partir da necessidade do teto - \\
participar do movimento emancipa \\
Estratégias travadas na luta pela permanência e na reividicação de direitos \\
Apropriação social do espaço: valor de uso se sobrepõe ao valor de troca \\
Busca pela real democratização das cidades
\end{tabular}

Elaboração própria 


\begin{tabular}{|c|c|c|}
\hline $1970-1990$ & $\leftrightarrow$ & PÓS 1990 \\
\hline Comunidades Eclesiais de Base & PONTOS DA PESQUISA & Ocupação Jardim da União \\
\hline $\begin{array}{l}\text { Igreja Católica progressista, } \\
\text { esquerda e sindicato }\end{array}$ & ATORES SOCIAIS & $\begin{array}{l}\text { Igrejas neopentecostais, } \\
\text { mundo do crime, Estado }\end{array}$ \\
\hline $\begin{array}{l}\text { Teologia da Libertação, } \\
\text { marxismo e "novo sindicalismo" }\end{array}$ & MATRIZES DISCURSIVAS & $\begin{array}{l}\text { Teologia da Prosperidade, } \\
\text { empreendedorismo monetarista } \\
\text { e militarismo }\end{array}$ \\
\hline $\begin{array}{l}\text { Projeto família operária: } \\
\text { extensa, católica, migrante e } \\
\text { pouca escolaridade }\end{array}$ & MODELO ORGANIZATIVO & $\begin{array}{l}\text { Alternativas de vida muito } \\
\text { individualizadas e heterogêneas }\end{array}$ \\
\hline $\begin{array}{l}7 \text { filhos por mulher/ divisão } \\
\text { sexual do trabalho tradicional }\end{array}$ & FAMilLA & $\begin{array}{l}1,5 \text { filhos por mulher / entrada } \\
\text { decisiva das mulheres no } \\
\text { mercado }\end{array}$ \\
\hline Muito alta & MIGRAÇÃO & Extremamente baixa \\
\hline Ampla maioria católica & RELIGIÃO & Forte expansão pentecostal \\
\hline \multirow[t]{2}{*}{$\begin{array}{l}\text { Operário e formal } \\
\text { como grande objetivo }\end{array}$} & TRABALHO & $\begin{array}{l}\text { Contratos terceirizados, } \\
\text { precários, informalidade }\end{array}$ \\
\hline & & $\begin{array}{l}\text { Empreendedorismo } \\
\text { como grande objetivo }\end{array}$ \\
\hline $\begin{array}{l}\text { Baixissima capacidade } \\
\text { de consumo }\end{array}$ & CONSUMO & Maior capacidade de consumo \\
\hline $\begin{array}{l}\text { Sacrificar-se hoje para uma } \\
\text { recompensa futura }\end{array}$ & NARRATIVA & Recompensa no "aqui e agora" \\
\hline $\begin{array}{l}\text { Reivindicação de direitos e } \\
\text { consciência critica e politica }\end{array}$ & QUESTÕES SOCIAIS & Esforço individual e meritocracia \\
\hline Estado-provedor & ESTADO & Estado-neoliberal \\
\hline
\end{tabular}

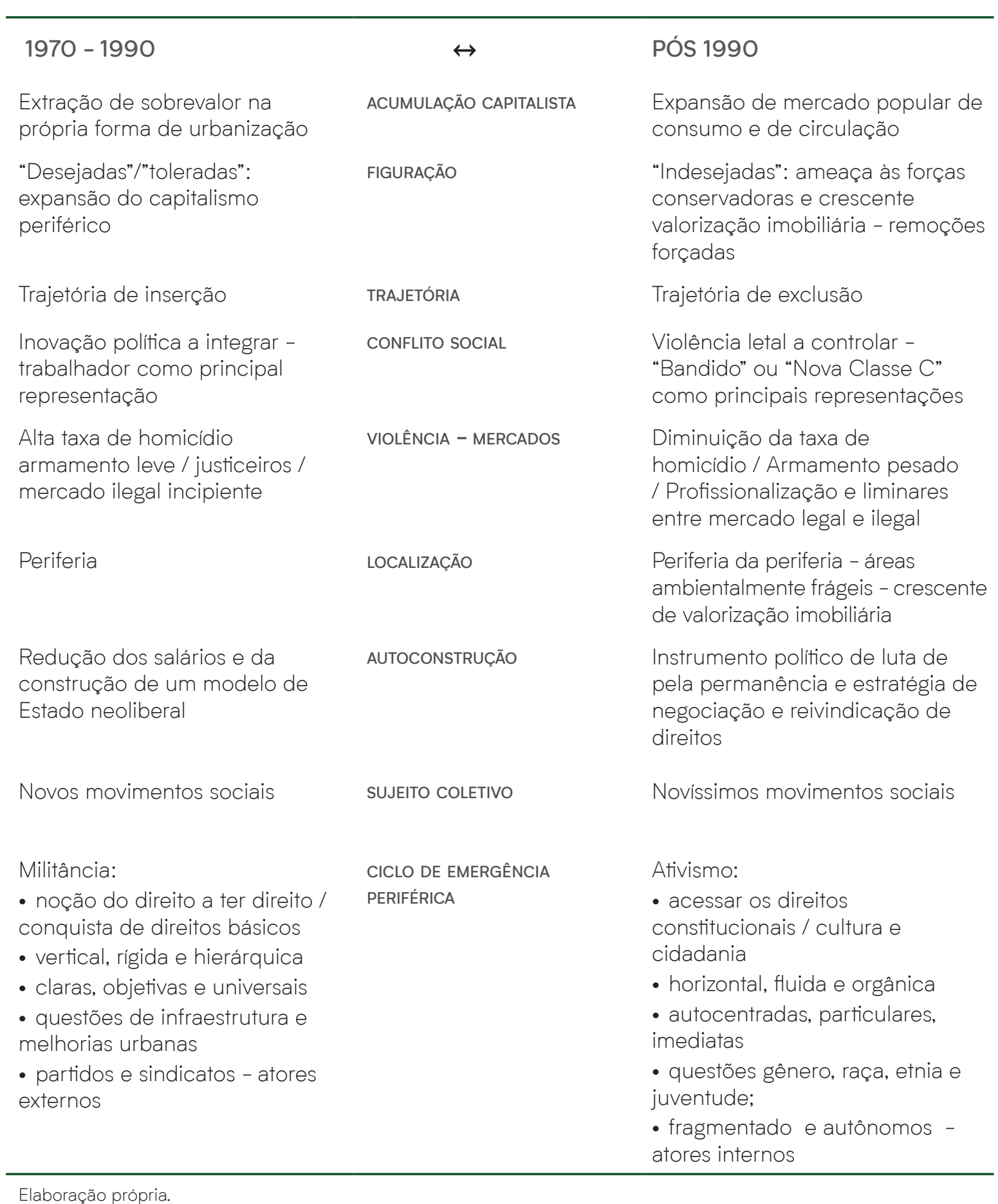




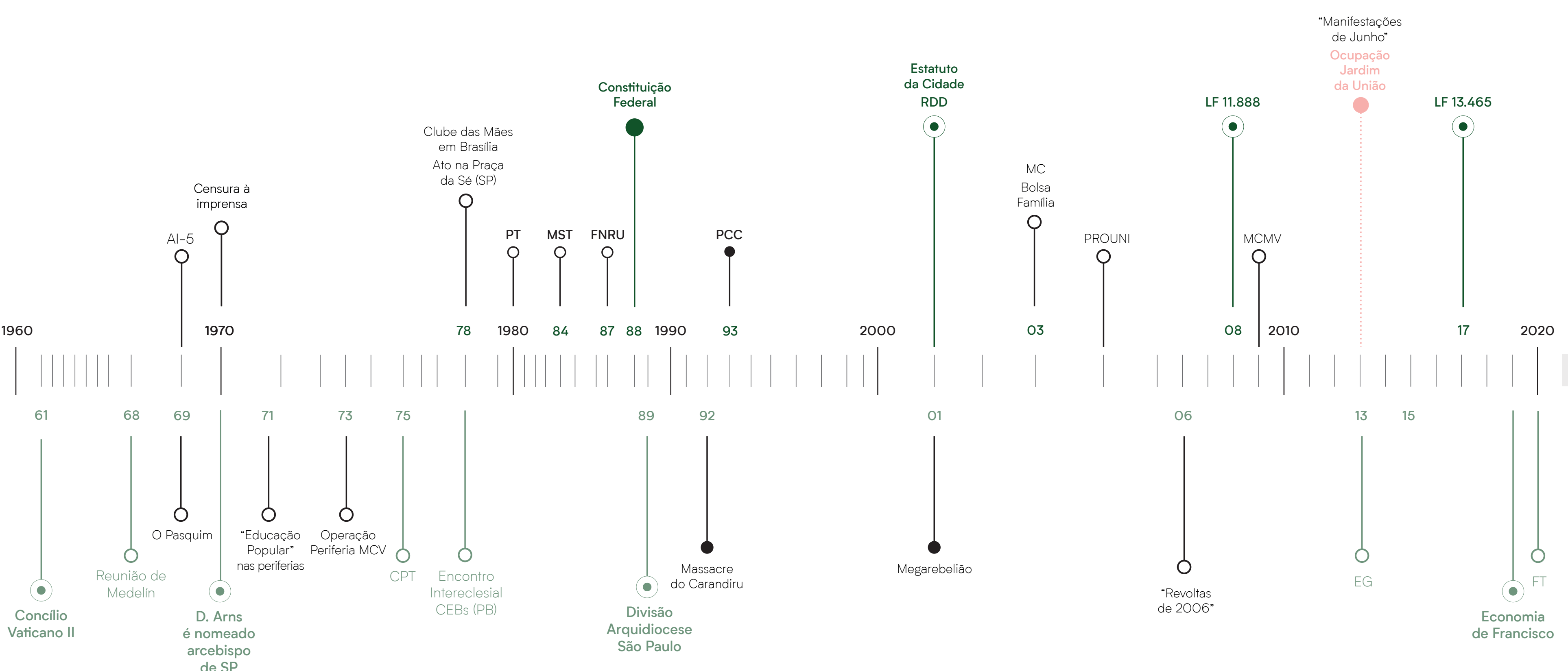

COMUNIDADES ECLESIAIS DE BASE 


\section{LISTA DE FIGURAS}

81 FIGURA 2.1 - Dom Paulo Evaristo Arns participando de uma reunião no âmbito da Operação Periferia.

83 FIGURA 2.2 e 2.3 - Bairro do Parque Nova Santo Amaro, Zona Su de São Paulo, na década de 1970 e, o mesmo bairro apenas um

84 FIGURA 2.4 - Celelebração do Dia Internacional da Mulher de 1980, em Vila Remo.

85 FIGURA 2.5 - Comissão do MCV encarregada da entrega de abaixo-assinado em Brasilia em 1978.

86 FIGURA 2.6 - Manifestação do Movimento Custo de Vida na Praça da Sé, em São Paulo.

86 FIGURA 2.7 - Manifestação do Movimento Custo de Vida na Praça da Sé, em São Paulo.

87 FIGURA 2.8 - Manifestação do Movimento Custo de Vida na Praça da Sé, em São Paulo.

87 FIGURA 2.9 - Manifestação do Movimento Custo de Vida na Praça da Sé, em São Paulo.

100 FIGURA 3.1 - Evolução da mancha urbana de São Paulo.

131 FIGURA 3.2 - Templo da Assembleia de Deus na comunidade Tavares Bastos, no Rio de Janeiro.

132 FIGURA 3.3 - Igreja Assembléia de Deus, em São Roque (SP).

138 FIGURA 3.4 - Tempo médio de viagem por transporte coletivo.

139 FIGURA 3.5 - Vulnerabilidade Social em São Paulo.

144 FIGURA 3.6 - Respectivamento, empregos formais nos setores de Comércio, Serviços e Indústrias de Transformação em 2000 e 2016.

150 FIGURA 4.1 - Localização da ocupação Jardim da União.

152 FIGURA 4.2 - Renda per capita no Jardim da União e entorno.

152 FIGURA 4.3 - Vulnerabilidade Social no Jardim da União e entorno.

154 FIGURA 4.4 - Remoções e ameaças de remoção na Zona Sul de São Paulo (2017-2019)

157 FIGURA 4.5 - Distância entre o ltajai e o Jardim da União.

164 FIGURA 4.6 - Barracão na ocupação do Itajal.

166 FIGURA 4.7 - Montagem de fotos das manifestações, atos e protestos organizados pelos moradores do ltajai e pela Rede Extremo Sul.
FIGURA 4.8 - Ocupação Jardim da União na fase da lona, "pova a partir de mutirão, com cozinha coletiva e barracão do "povo".

176 FIGURA 4.9 - Ocupação Jardim da União na fase da madeira, organizada a partir de mutirão, reconstrução do barracão do "povo" para as muitas reuniões desse periodo.

178 FIGURA 4.10 - Espaços comuns: creche "Filhos da Luta", biblioteca, cooperativas de costura e de reciclagem, campo de tutebol e horta comunitária.

182 FIGURA 4.11 - Manifestação dos moradores do Jardim da União na CDHU.

188 FIGURA 4.12 - Jardim da União delimitado como ZEIS 4.

190 FIGURA 4.13 - Oficinas de diagnóstico comunitário com os moradores do Jardim da União.

192 FIGURA 4.14 e 4.15 - Sistematização da visita dos técnicos da assessoria e das oficinas comunitárias.

196 FIGURA 4.16 - Proposta 1, na qual foi mantido o tecido urbano existente.

196 FIGURA 4.17 - Proposta 2, reconfiguração dos lotes e ruas.

197 FIGURA 4.18 - Versão final do Plano Popular Urbanístico Dcupação Jardim da União.

203 FIGURA 4.19 - Divisão das 17 quadras e nomes das ruas.

206 FIGURA 4.20 - Participantes do CPPATHIS em atividades na FAUUSP e no Jardim da União.

209 FIGURA 4.21 - Parte do material preparado para discussão com a CETESP - impactos ambientais de uma remoção.

212 FIGURA 4.22 - Sequência histórica recente do Jardim da União. FIGURA 4.23 - Atividades realizadas na Frente de Dados e n Frente de Melhorias Habitacionais - oficinas, apresentação do documentário e censo.

222 FIGURA 4.24 - Atividades realizadas na Frente de Infraestrutura: Contenção e Drenagem - reunião com os moradores, maquetes, mutirão para construção da "biovaleta".

230 FIGURA 4.25 e 4.26 - Faixas espalhadas pela ocupação para inibição de venda de lotes.

236 FIGURA 4.27 - Horta comunitária na ocupação Jardim da União 
246 FIGURA 4.29 - Ocupação Jardim da União na fase do tijolo, construçoes em alvenaria, inclusive o barracão, e inicio da verticalização.

248 FIGURA 4.30 - Implementação de infraestrutura: redes de ggua, esgoto e energia elétrica. Início da pavimentação das ruas e instalação das placas com os nomes das vias.

250 FIGURA 4.31 - Expansão de comércios e serviços: igrejas, anchonetes, quitandas, salões de beleza, lojas de material de construçãa, padarias, pizzarias, bares e restaurantes.

252 FIGURA 4.32 - Foło aérea da ocupação Jardim da União realizada no primeiro semestre de 2021.

FIGURA 4.33 - Linha do Tempo sintese do Jardim da União.

282 FIGURA 5.1 - Linha do Tempo com marcos históricos em diálogo com a dissertação.

\section{LISTA DE GRÁFICOS}

101 GRÁFICO 3.1 - Avanço da Urbanização

119 GRÁFICO 3.2 - Taxa de mortalidade por homicidio

130 GRÁFICO 3.3 - Transição religiosa no Brasil

239 GRÁFICOS 4.1 e 4.2 - Tipo de construção/material das casas

242 GRÁFICO 4.3 - Religião

243 GRÁFICO 4.4 E 4.5 - Tipo de ocupação/trabalho

\section{LISTA DE TABELAS}

111 TABELA 3.1 - Taxa de crescimento populacional, segundo anel, no municipio de São Paulo.

129 TABELA 3.2 - Declaração religiosa na RMSP

129 TABELA 3.3 - Grupos religiosos no Brasi

143 TABELA 3.4 - Brasil, pessoas ocupadas

239 TABELA 4.1 - Tipo de construção/material

240 TABELA 4.2 - Verticalização das construçõe

240 TABELA 4.3 - Construções ligadas às redes de infraestrutura

242 TABELA 4.4 - Religião

243 TABELA 4.5 - Tipo de ocupação/trabalho

\section{LISTA DE QUADROS}

QUADRO 1.1 - Momentos e categorias do pontificado de Francisco sobre a economia

122 QUADRO 3.1 - Coexistência de regimes

279 QUADRO 5.1 - Permanências

280 QUADRO 5.2 - Deslocamentos 


\section{REFERÊNCIAS BIBLIOGRÁFICAS}

ABERS, R.; SERAFIM, L.; TATAGIBA, L. Repertórios de interação estado-sociedade em um estado heterogêneo: a experiência na Era Lula. Dados, v. 57, n. 2, p. 325-357, jun. 2014.

ADORNO, S.; SALLA, F. Criminalidade organizada nas prisões e os ataques do PCC. Estudos Avançados, v. 21, n. 61, p. 7-29, 2007.

ALMEIDA, R. DE. Religião na metrópole paulista. Revista Brasileira de Ciências Sociais, v. 19, n. 56, p. 15-27, 2004

ALMEIDA, R. DE. Bolsonaro Presidente: conservadorismo, evangelismo e a crise brasileira. Novos Estudos - CEBRAP, v. 38, n. 1, p. 185-213, 2019.

ALMEIDA, R. DE; D’ANDREA, T.; DE LUCCA, D. Situações periféricas: etnografia comparada de pobrezas urbanas. Novos Estudos - CEBRAP, n. 82, p. 109-130, nov. 2008.

ALMEIDA, R. DE; MONTERO, P. Trânsito religioso no Brasil. São Paulo em Perspectiva, v. 15, n. 3, p. 92-101, 2001.

ALVES, J. From Necropolis to Blackpolis: Necropolitical Governance and Black Spatial Praxis in São Paulo, Brazil. Antipode, v. 46, n. 2, p. 323-339, 2014

AMORIM, C. CV-PCC: a irmandade do crime. Rio de Janeiro: Record, 2004

ANDRADE, P. F. A questão da propriedade dos bens na Doutrina Social da Igreja. Encontros Teológicos, v. 36, n. 1, p. 69-94, abr. $2 \mathrm{O} 21$.

ARIAS, E. D. The dynamics of criminal governance: Networks and social order in Rio de Janeiro. Journal of Latin American Studies, v. 38, n. 2, p. 293-325, 2006.

BACKHEUSER, E. Habitações populares. In: Relatório apresentado ao Exm. Sr. Dr. J.J. Seabra, Ministro da Justiça e Negócios Interiores. Rio de Janeiro: Imprensa Nacional, 1906.

BARROS, J.; DAL'BÓ DA COSTA, A.; RIZEK, C. (EDS.). Os limites da acumulação, movimentos e resistências nos territórios. São Carlos: IAU USP, 2018
BASTOS, C. D. et al. Entre o espaço abstrato e o espaço diferencial: ocupações urbanas em Belo Horizonte. Revista Brasileira de Estudos Urbanos e Regionais, v. 19, n. 2, p. 251, 27 abr. 2017.

BERALDO, A. Negociando a vida e a morte: estado, igreja e crime em uma favela de Belo Horizonte. Tese apresentada ao Programa de Pós-Graduação em Sociologia-São Carlos: Universidade Federal de São Carlos, 2020.

BETTO, F. O que é comunidade eclesial de base. São Paulo: Abril Cultural / Brasiliense, 1985. v. 46.

BIONDI, K. A ética evangélica e o espírito do crime. Anais $26^{\circ}$ Reunião brasileira de antropologia. Porto Seguro, 2016.

BITTENCOURT, G.; MARKUN, P. O Cardeal do povo: D. Paulo Evaristo Arns. São Paulo: Alfa Omega, 1979.

BOFF, L. E a Igreja se fez povo. Petrópolis: Vozes, 1986

BOLAFFI, G. Habitação e urbanismo: o problema e o falso problema. In: A produção capitalista da casa (e da cidade) no Brasil industrial. 2. ed. São Paulo: Alfa Omega, 1982 [1975]. p. 37-70.

BONDUKI, N.; ROLNIK, R. Periferia da Grande São Paulo: reprodução do espaço como expediente de reprodução da força de trabalho. In: A produção capitalista da casa (e da cidade) no Brasil industrial. 2. ed. São Paulo: Alfa Omega, 1982. p. 117-154.

BORAN, J. O senso crítico e o método ver, julgar, agir. São Paulo: Loyola, 1977.

BOSI, E. Memória e sociedade: lembrança de velhos. 3. ed. São Paulo: Companhia Das Letras, 1994.

BOULOS, G. De que lado você está?: reflexões sobre a conjuntura política e urbana no Brasil. São Paulo: Boitempo, 2015.

BRAGA, R. A rebeldia do precariado: trabalho e neoliberalismo no Sul global. São Paulo: Boitempo, 2017. 
BRANT, V. C. Da resistência aos movimentos sociais: a emergência das classes populares em São Paulo. In: São Paulo: o povo em movimento. Petrópolis: Vozes / Cebrap, 1980. p. 9-28.

BUENO, L. M. M. Projeto e favela: metodologia para projetos de urbanização. Tese apresentada à Faculdade de Arquitetura e Urbanismo-São Paulo: Universidade de São Paulo, 2000.

CABRAL, G.; SILVA, C. DE A. S.; TESTOLINO, P. A extensão universitária e seu potencial transformador: prática no (e com) o território do Jardim da União. Limiaridade: processos e práticas em arquitetura e urbanismo. Anais... In: VI Encontro da Associação Nacional de Pesquisa e Pós-Graduação em Arquitetura e Urbanismo. Brasília: 2020.

CALDEIRA, T.; HOLSTON, J. Democracy and Violence in Brazil. In: Comparative Studies in Society and History, v. 41, n. 4, p. 691-729, 1999.

CAMARGO, C. P. F. DE et al. São Paulo 1975: crescimento e pobreza. 4. ed. São Paulo: Loyola, 1975.

CAMARGO, C. P. F. DE ; SOUZA, B. M. DE; PIERUCCI, A. F. DE O. Comunidades Eclesiais de Base. In: São Paulo: o povo em movimento. Petrópolis: Vozes / Cebrap, 1980. p. 59-82.

CARDOSO, A. L. Avanços e desafios na experiência brasileira da urbanização de favelas. In: Cadernos Metrópole. São Paulo, v. 17, p. 219-240, 2007.

CARVALHO, I.; LANIADO, R. Rediscutindo o tema: movimentos sociais e democracia. [s.l.] (mimeo), 1989.

CAVALCANTI, M. Do barraco à casa: tempo, espaço e valor(es) em uma favela consolidada. Revista Brasileira de Ciências Sociais, v. 24, n. 69, p. 69-80, fev. 2009.

CERTEAU, M. DE. A invenção do cotidiano: artes de fazer. Petrópolis: Vozes, 1994.

CHAUI, M. Prefácio. In: Quando novos personagens entraram em cena. Rio de Janeiro: Paz e Terra, 1988.

DAGNINO, E. Sociedade civil, participação e cidadania: de que estamos falando? In: Políticas de Ciudadania y Sociedad Civil en Tiempos de Globalización. Caracas: FaCes/Universidad de Venezuela, 2004. p. 95-111.
DAL'BÓ DA COSTA, A. Luta social e a produção neoliberal do espaço: as trajetórias das ocupações Vila Soma, Zumbi dos Palmares e Pinheirinho. Doutorado em Teoria e História da Arquitetura e do Urbanismo-São Carlos: Universidade de São Paulo, 2019.

D’ANDREA, T. P. A Formação dos Sujeitos Periféricos: Cultura e Política na Periferia de São Paulo. Tese apresentada à Faculdade de Filosofia, Letras e Ciências Humanas-São Paulo: Universidade de São Paulo, 2013.

DARDOT, P.; LAVAL, C. A nova razão do mundo: ensaio sobre a sociedade neoliberal. 1a. ed ed. São Paulo: Boitempo, 2016.

DENALDI, R. Políticas de urbanização de favelas: evolução e impasses. Tese apresentada à Faculdade de Arquitetura e Urbanismo-São Paulo: Universidade de São Paulo, 2003.

DOIMO, A. M. A vez e a voz popular: movimentos sociais e participação política no Brasil pós 70. Rio de Janeiro: Relume-Dumará, 1995.

FELTRAN, G. DE S. Desvelar a política na periferia: história de movimentos sociais em São Paulo. Dissertação em Ciência Política-Campinas: Universidade Estadual de Campinas, 2003.

FELTRAN, G. DE S. O legítimo em disputa: As fronteiras do "mundo do crime" nas periferias de São Paulo. Dilemas, p. 93-126, 2008.

FELTRAN, G. DE S. Fronteiras de tensão: política e violência nas periferias de São Paulo. São Paulo: Editora UNESP, 2011.

FELTRAN, G. DE S. O valor dos pobres: a aposta no dinheiro como mediação para o conflito social contemporâneo. CADERNO CRH, v. 27, n. 72, p. 495-512, 2014.

FELTRAN, G. DE S. Irmãos: uma história do PCC. São Paulo, SP: Companhia Das Letras, 2018.

FELTRAN, G. DE S. Das Prisões às Periferias: coexistência de regimes normativos na "Era PCC". In: Revista Brasileira de Execução Penal, v. 1, n. 2, p. 45-71, 202Ob.

FERRARA, L. N.; GONSALES, T. A.; COMARÚ, F. DE A. Espoliação urbana e insurgência: conflitos e contradições sobre produção imobiliária e moradia a partir de ocupações recentes em São Paulo. Cadernos Metrópole, v. 21, n. 46, p. 807-830, 2019. 
FERREIRA, P. E. B. O filé e a sobra. As favelas no caminho do capital imobiliário. Tese apresentada à Faculdade de Arquitetura e Urbanismo-São Paulo: Universidade de São Paulo, 2017.

FERRO, S. A casa popular. São Paulo: GFAU, 1969.

FISCHER, R. M. A favela como solução de vida: um estudo do papel dos grupos informais na participação social de classes populares em São Paulo. Dissertação em Sociologia apresentada à FFLCH—São Paulo: Universidade de São Paulo, 1977.

FONSECA, C. O anonimato e o texto antropológico. Dilemas éticos e políticos da etnografia "em casa". Anais... In: VI RAM, Mesa redonda trayectorias y diversidad: las estrategias en investigación etnográfica. Montevideo: 2005.

FORTUNA, C.; LEITE, R. P. Plural de Cidade: Novos Léxicos Urbanos. Coimbra: Almedina, 2015.

FRANCISCO. Exortação apostólica Evangelii Gaudium: a alegria do evangelho do Papa Francisco ao episcopado, ao clero, às pessoas consagradas e aos fiéis leigos sobre $o$ anúncio do evangelho no mundo atual. São Paulo: Paulinas, 2013.

FRANCISCO. Carta Encíclica Laudato Si': sobre o cuidado da casa comum. São Paulo: Paulinas, 2015a.

FRANCISCO. Carta Encíclica Fratelli Tutti: sobre a fraternidade e a amizade social. São Paulo: Paulinas, 202Ob.

FREIRE, P. Pedagogia do oprimido. 68. ed. São Paulo: Paz e Terra, 2019 [1968].

FREIRE, P. À sombra desta mangueira. São Paulo, SP: Olho d'Água, 1995.

FRÚGOLI, H. O urbano em questão na antropologia: interfaces com a sociologia. Revista de Antropologia, São Paulo: USP. v. 28, n. 1, 2005.

FUKS, J. A ocupação. São Paulo: Companhia Das Letras, 2019.

GIDDENS, A. Sociologia. Tradução: Santa Regina Netz. 4. ed. Porto Alegre: Artmed, 2005.

GOHN, M. DA G. Novas Teorias dos Movimentos Sociais. São Paulo: Loyola, 2014.
GOHN, M. DA G. Los movimientos sociales brasileños de la última década. In: Movimientos sociales en America Latina: perspectivas, tendencias y casos. Buenos Aires: CLACSO, 2017. p. 619-639

GRAFMAYER, Y. Sociologie urbaine. Paris: Nathan, 1995

HADDAD, A. M. C. N. F. et al. A luta pelo direito de estar: o caso do Jardim da União (SP). X Congresso Brasileiro de Direito Urbanístico. Anais...Palmas: 2019.

HARVEY, D. O direito à cidade. Revista Piauí, n. 82, jul. 2013.

HARVEY, D. A loucura da razão econômica: Marx e o capital no século XXI. Tradução: Artur Renzo. 1. ed. São Paulo: Boitempo, 2018.

HOLSTON, J. Cidadania insurgente: disjunções da democracia e da modernidade no Brasil. São Paulo: Companhia Das Letras, 2013.

JESUS, C. DE J. Quarto de Despejo: Diário de uma Favelada. São Paulo: Francisco Alves, 1960.

KOWARICK, L. A espoliação urbana. Rio de Janeiro: Paz e Terra, 1980.

KOWARICK, L. Escritos Urbanos. São Paulo: Editora 34, 2000.

KOWARICK, L. Viver em risco: sobre a vulnerabilidade no Brasil urbano. Novos estudos Cebrap, v. 63, p. 9-30, jul. 2002.

KOWARICK, L. Viver em risco - sobre a vulnerabilidade socioeconômica e civil. São Paulo: Editora 34, 2009.

LAGO, L. C. DO. Favela-loteamento: reconceituando os termos da ilegalidade e da segregação urbana. Cadernos Metrópole, v. 9, p. 119-133, 2003

LAGO, L. C. DO. Extensão Universitária como ação educadora para uma outra cidade. In: Além dos muros da Universidade. 1. ed. São Paulo: FAU-USP / ANPUR, 2019. p. 33-45.

LEFEBVRE, H. O direito à cidade. Tradução: Rubens Eduardo Ferreira Frias. São Paulo: Centauro Editora, 2001.

LEFEBVRE, H. A revolução urbana. Tradução: Sérgio Martins; Tradução: Margarida Maria De Andrade. Belo Horizonte: Editora UFMG, 2002 
LEFEBVRE, H. A produção do espaço. Trad. Doralice Barros Pereira e Sérgio Martins (do original: La production de l'espace. 4 éd. Paris: Éditions Anthropos, 2000). 2006.

LEPETIT, B. Por uma nova história urbana. São Paulo: Edusp, 2001

LINS, R. M. D. A Regularização Fundiária como Reconhecimento de Direitos: os empreendimentos residenciais Vila Emater II e Vista Atlântica. In: Cidade (i)Legal. Rio de Janeiro: Maud, 2008. p. 219-241.

LOPES, M. V. Planejamento territorial na interface rural-urbana: unidade de gestão do periurbano sul de São Paulo. Trabalho Final de Graduação apresentado à Faculdade de Arquitetura e Urbanismo - São Paulo: Universidade de São Paulo, 2018

LORO, T. J. Espaço e poder na Igreja: A divisão da Arquidiocese de São Paulo. Tese em Geografia Humana-São Paulo: Universidade de São Paulo, 1995.

LOURENÇO, T. C. B. Depoimento: Tiago Castelo Branco Lourenço - Arquitetos Sem Fronteiras. In: Saberes [Auto] Construídos. Belo Horizonte: Associação Imagem Comunitária, 2015.

LÖWY, M. O que é cristianismo da libertação: religião e política na América Latina. São Paulo: Editora Expressão Popular, 2016.

MACHADO DA SILVA, L. A. Violência urbana, sociabilidade vioenta e agenda pública. In: Vida sob cerco: violências e rotina nas favelas do Rio de Janeiro. Rio de Janeiro: Nova Fronteira, 2008. p. 35-46.

MANSO, B. P.; NUNES DIAZ, C. PCC, sistema prisional e gestão do novo mundo do crime no Brasil. Revista Brasileira de Segurança Pública, v. 11, n. 2, p. 10-29, 2017.

MARICATO, E. Autoconstrução: a arquitetura possível. In: Trabalho apresentado na 28 reunião da SBPC (Brasília). São Paulo: FAU-USP, 1976.

MARICATO, E. (ED.). A produção capitalista da casa (e da cidade) no Brasil industrial. 2. ed. São Paulo: Alfa Omega, 1982.

MARICATO, E. Metrópole na periferia do capitalismo: ilegalidade, desigualdade e violência. São Paulo: Editora Hucitec, 1996.
MARICATO, E. A terra é um nó na sociedade brasileira...também nas cidades. Cultura Vozes, v. 93, n. 6, p. 7-22, 1999.

MARICATO, E. Urbanismo na periferia do mundo globalizado: metrópoles brasileiras. São Paulo em Perspectiva, v. 14, n. 4. p. 21-33, 2000.

MARICATO, E. Brasil, cidades: alternativas para a crise urbana. Petrópolis: Editora Vozes, 2001.

MARICATO, E. Metrópole, legislação e desigualdade. Estudos Avançados, v. 17, n. 48, p. 151-167, 2003.

MARICATO, E. O impasse da política urbana no Brasil. Petrópolis: Editora Vozes, 2011

MARICATO, E. As ideiais fora do lugar e o lugar fora das ideias. In: A cidade do pensamento único: desmanchando consensos. Coleção Zero à esquerda. 8a. ed. Petrópolis: Editora Vozes, 2013a. p. 121-192.

MARICATO, E. É a questão urbana, estupido! In: Cidades rebeldes: Passe Livre e as manifestações que tomaram as ruas do Brasil. São Paulo: Boitempo / Carta Maior, 2013b. p. 19-26.

MARICATO, E. Formação e impasse do pensamento crítico sobre a cidade periférica. In: 0 impasse da política urbana no Brasil. 3. ed. Petrópolis: Vozes, 2014. p. 105-170.

MARINO, A. Ação cultural e territórios insurgentes: uma pesquisa-ação com coletivos culturais de São Paulo e Bogotá Dissertação em Planejamento e Gestão do Território-Santo André: Universidade Federal do ABC, 2016.

MARQUES, E. A metrópole de São Paulo no início do século XXI. Revista USP, Dossiê Metrópoles. n. 102, p. 23-32, 2014.

MARQUES, E.; REQUENA, C. O centro voltou a crescer?: trajetórias demográficas diversas e heterogeneidade na São Paulo dos anos 2000. Novos Estudos - CEBRAP, n. 95, p. 17-37, mar. 2013.

MARQUES, V. A. O irmão que virou irmão : rupturas e permanências na conversão de membros do PCC ao pentecostalismo na Vila Leste - SP. Dissertação apresentada ao Programa de Pós Graduação em Ciências da Religião-São Paulo: Pontifícia Universidade Católica de São Paulo, 2013. 
MARX, K. O capital: O processo de produção do capital [Livro 1]. Tradução: Rubens Enderle. 2. ed. São Paulo: Boitempo, 2017 [1867].

MAUTNER, Y. A cria rebelde. Dissertação apresentada à Faculdade de Arquitetura e Urbanismo-São Paulo: Universidade de São Paulo, 1981.

MAUTNER, Y. A periferia como fronteira de expansão do capital. In: O processo de urbanização no Brasil. São Paulo: FUPAM : Edusp, 1999. p. 245-259.

MISSE, M. Cinco teses equivocadas sobre a criminalidade urbana violenta no Brasil. Violência ou Participação Social no Rio de Janeiro. Anais...Rio de Janeiro: 1995.

MISSE, M. Crime e violência no Brasil contemporâneo: estudos de sociologia do crime e da violência urbana. Rio de Janeiro: Editora Lumen Juris, 2006.

MISSE, M. Sobre a acumulação social da violência no Rio de Janeiro. Civitas - Revista de Ciências Sociais, v. 8, n. 3, 2009.

MISSE, M. Crime, Sujeito e Sujeição Criminal: aspectos de uma contribuição analítica sobre a categoria "bandido". Lua Nova: Revista de Cultura e Política, n. 79, p. 235-244, 2010.

MORADO NASCIMENTO, D. (ED.). Saberes [auto] construídos. Belo Horizonte: Associação Imagem Comunitária, 2015.

MORADO NASCIMENTO, D. O que é extensão? incertezas e provocações. In: Dimensões do intervir em favelas: desafios e perspectivas. 1. ed. São Paulo: Peabiru TCA / Coletivo LabLaje, 2019.

MORAIS, A. C. Periferias: da militância ao ativismo. Trabalho Final de Graduação apresentado à Faculdade de Arquitetura e Urbanismo - São Paulo: Universidade de São Paulo, 2018.

NEVES, B. et al. Lutas Territoriais: Resistências ao Avanço do Urbanismo Neoliberal. In: Cidade Estado Capital: reestruturação urbana e resistência em Belo Horizonte, Fortaleza e São Paulo. 1. ed. São Paulo: FAU-USP, 2018. p. 223-241.

OLIVEIRA, F. DE. Crítica à razão dualista: 0 ornitorrinco. 1a. ed ed. São Paulo, SP: Boitempo, 2003 [1972].

PASTERNAK-TASCHNER, S. Favelas no município de São Paulo. In: A luta pelo espaço. Petrópolis: Vozes, 1978.
PASTERNAK-TASCHNER, S. Espaço e população nas favelas de São Paulo. XIII Encontro da Associação Brasileira de Estudos Populacionais (anais). Anais...Ouro Preto: 2002.

PASTERNAK-TASCHNER, S.; D'OTTAVIANO, C. Favelas no Brasil e em São Paulo: avanços nas análises a partir da Leitura Territorial do Censo de 2010. Cadernos Metrópole, v. 18, n. 35, p. 75-100, jun. 2016.

PASTERNAK-TASCHNER, S. P.; BÓGUS, L. M. M. SÃO PAULO: O CALEIDOSCÓPIO URBANO. São Paulo em Perspectiva, v. 15, n. 1, p. 31-44, jan. 2001.

PAULANI, L. M. Desenvolvimentismo, planejamento e investimento público nos cinco mil dias do lulismo. In: Cinco mil dias: o Brasil na era do lulismo. 1. ed. São Paulo: Boitempo, 2017. p. 91-99.

PIERUCCI, F. A propósito do auto-engano em sociologia da religião. Novos Estudos - CEBRAP, v. 49, p. 99-117, 1997.

PIMENTA, J. A. DE M. Para a remodelação do Rio de Janeiro, discursos pronunciados no Rotary Club do Rio de Janeiro. Rio de Janeiro: 1926

QUEIROZ, C. Fé Pública. Revista Pesquisa FAPESP, n. 286, p. 12-19, 2019.

RAUPP, K. DA S.; SUSIN, L. C. A Economia segundo Francisco. Aspectos principais do Pensamento Econômico no atual Pontificado a partir da mensagem do Papa aos participantes do evento "The Economy of Francesco". Revista de Cultura Teológica, n. 98, p. 199-213, abr. 2021.

RODRIGUES, E. L. A Estratégia Fundiária dos movimentos populares na produção autogestionária da moradia. Dissertação apresentada à Faculdade de Arquitetura e Urbanismo-São Paulo: Universidade de São Paulo, 2013.

ROLNIK, R. As vozes das ruas: as revoltas de junho e suas interpretações [Apresentação]. In: Cidades rebeldes: Passe Livre e as manifestações que tomaram as ruas do Brasil. São Paulo: Boitempo / Carta Maior, 2013. p. 7-12.

ROSA, T. T. Fronteiras em disputa na produção do espaço urbano: a trajetória do "Gonzaga" de favela a bairro de periferia. Dissertação em História-Campinas: Universidade Estadual de Campinas, 26 mar. 2008. 
ROSA, T. T. Cidades outras: pobreza, moradia e mediações em trajetórias urbanas limiares. Doutorado em Teoria e História da Arquitetura e do Urbanismo-São Carlos: Instituto de Arquitetura e Urbanismo da Universidade de São Paulo, 2014.

ROUSSEAU, J. J. Discurso sobre a origem e os fundamentos da desigualdade entre os homens. Tradução: Lourdes Santos Machado. São Paulo: Nova Cultural, 1997.

ROVATI, J.; D’OTTAVIANO, C. Para Além da Sala de Aula. Extensão universitária e planejamento urbano e regional. São Paulo: FAUUSPIANPUR, 2017.

ROVATI, J.; D’OTTAVIANO, C. Além dos Muros da Universidade. São Paulo: ANPUR, 2019.

ROY, A. Cidades faveladas: repensando o urbanismo subalterno. E-metropolis, n. 31, ano 8, p. 5-21, dez. 2017.

SADER, E. Quando novos personagens entraram em cena: experiências, falas e lutas dos trabalhadores da Grande São Paulo, 1970-1980. Rio de Janeiro: Paz e Terra, 1988.

SAMPAIO, M. R.; LEMOS, C. Habitação popular paulista autoconstruída. São Paulo: FAU-USP, 1978.

SANCHES, D.; STEVES, J.; PIOTTO, M. Ocupações e urbanismo insurgentes: área central de São Paulo. III ICHT 2019. Anais... In: Colóquio Internacional - Imaginário: construir e habitar a terra. São Paulo: FAU-USP, 2019.

SANTO AMORE, C.; LEITÃO, K. Favela de Nome, cidade de fato. In: Dimensões do intervir em favelas: desafios e perspectivas. 1. ed. São Paulo: Peabiru TCA / Coletivo LabLaje, 2019.

SANTO AMORE, C.; PEREIRA, R. B.; HORIGOSHI, M. R. De afeto e de escola: formação em assessoria e assistência técnica. In: Dimensões do intervir em favelas: desafios e perspectivas. 1. ed. São Paulo: Peabiru TCA / Coletivo LabLaje, 2019.

SANTO AMORE, C. et al. Autoconstrução pelo direito de estar. In: Urbanismo Biopolítico. Belo Horizonte: Agência de Iniciativas Cidadãs, 2021

SANTOS, M. Metrópole corporativa fragmentada. São Paulo: Nobel, 1990.
SCANNONE, J. C. Pope Francis and the Theology of the People. Theological Studies, v. 77, n. 1, p. 118-135, 2016.

SCANNONE, J. C. La teología del pueblo: raíces teológicas del papa Francisco. Burgos: Sal Terrae, 2017.

SILVA, C. DE A. Antonico: a rede das estruturas híbridas de sociabilidade. Trabalho Final de Graduação apresentado à Faculdade de Arquitetura e Urbanismo-São Paulo: Universidade Presbiteriana Mackenzie, 2017.

SILVA, C. DE A. S. et al. Produção popular do espaço como forma de resistência - um relato a partir do olhar da assessoria técnica. Revista Indisciplinar, v. 5, p. 244-263, 2019.

SILVA, C. DE A. S.; RAUPP, K. S.; BRASILEIRO, E. Mestre, onde moras? (Jo 1, 38) Um olhar crítico e construtivo sobre a cidade à luz da Economia de Francisco. Vida Pastoral, v. 337, p. 14-23, 2021

SILVA, E. A. DA. Ocupação irregular e narrativas: as remoções como apagamento da experiência. Contemporânea, v. 10, n. 3, p. 1403-1428, dez. 2020.

SINGER, P.; BRANT, V. C. (EDS.). São Paulo: o povo em movimento. Petrópolis: Vozes / Cebrap, 1980.

SINHORETTO, J. Controle social estatal e organização do crime em São Paulo. Dilemas, v. 7, n. 1, p. 167-196, 2014.

SMITH, R. Propriedade da terra \& transição. São Paulo: Brasiliense, 1990.

TANAKA, G. M. M. Periferia: conceito, práticas e discursos. Práticas sociais e processos urbanos na metrópole de São Paulo. Dissertação apresentada à Faculdade de Arquitetura e Urbanismo-São Paulo: Universidade de São Paulo, 2006.

TELLES, V. DA S. et al. (EDS.). Nas tramas da cidade: trajetórias urbanas e seus territórios. São Paulo: Associação Editorial Humanitas, 2006.

TELLES, V. DA S. Debates: a cidade como questão. In: Nas tramas da cidade: trajetórias urbanas e seus territórios. São Paulo: Associação Editorial Humanitas, 2006.

TELLES, V. DA S. Ilegalismos urbanos e a cidade. Novos Estudos - CEBRAP, n. 84, p. 153-173, 2009. 
TELLES, V. DA S. A cidade nas fronteiras do legal e ilegal. Belo Horizonte: Argvmentvm, 2010

VALLADARES, L. DO P. (ED.). Passa-se uma casa: análise do programa de remoção de favelados do Rio de Janeiro. Rio de Janeiro: Zahar, 1978.

VALLADARES, L. DO P. Habitação em questão. Rio de Janeiro: Zahar, 1980.

VALLADARES, L. DO P. A invenção da favela: do mito de origem a favela. 1a. ed ed. Rio de Janeiro: Editora FGV, 2005.

VENTURA, Z. Cidade partida. São Paulo: Companhia Das Letras, 1994.

VIANA, L. DE A. Chão, pó, poeira: a produção social do espaço a partir de ocupações recentes na cidade de São Paulo. Tese apresentada à Faculdade de Arquitetura e UrbanismoSão Paulo: Universidade de São Paulo, 10 jul. 2020.

VIANNA, H. (ED.). Galeras cariocas: territórios de conflitos e encontros culturais. Rio de Janeiro: UFRJ, 1997.

WEFFORT, F. Por que democracia? São Paulo: Brasiliense, 1984

ZALUAR, A. Violência e crime. In: O que ler na ciência social brasileira (1970-1995). São Paulo: Sumaré, ANPOCS, CAPES, 1999. v. 1p. 13-107.

\section{OUTRAS REFERÊNCIAS}

ALESSI, G.; OLIVEIRA, R. Os filhos de porteiros que chegaram à universidade têm um orgulho que o ministro Paulo Guedes ignora. Disponível em: <https://brasil.elpais.com/ brasil/2O21-04-30/os-filhos-de-porteiros-que-chegaram-a-universidade-tem-um-orgulho-que-o-ministro-paulo-guedes-ignora.html?utm_source=Facebook\&ssm=FB_BR_CM\&fbclid=IwAR2XUtJrau6440eHtyvAfik9g_7k3cGdqdNYEXM7DuxOxJoSGlgA349V18s\#Echobox=16198262O7>. Acesso em: 27 ago. 2021.

ALONSO JR., A. et al. Cães e bombas reprimem movimento popular. Disponivel em: <http://memorialdademocracia. com.br/card/caes-e-bombas-reprimem-movimento-popular>. Acesso em: 10 ago. 2021.
CONRADO, Berning. Pé e Fé na caminhada, 1987. Disponível em: <https://www.youtube.com/watch?v=eS6OruVYU8M>. Acesso em: 3 set. 2021

FELTRAN, G. DE S. Valor dos pobres - Seminários Cebrap, 2015. Disponivel em: <https://www.youtube.com/watch?v=DLJKX9JhrmM>. Acesso em: 8 jul. 2020.

FELTRAN, G. DE S. Formas elementares da vida política: sobre o movimento totalitário no Brasil (2013-). Blog Novos Estudos Cebrap, 202Oa. Disponível em: <http://novosestudos.com.br/ formas-elementares-da-vida-politica-sobre-o-movimento-totalitario-no-brasil-2013/>. Acesso em: 17 ago. 2020.

FRANCISCO. Discurso do Papa Francisco aos participantes no $1^{\circ}$ Encontro Mundial dos Movimentos Populares. 2014. Disponível em: <https://www.vatican.va/content/francesco/pt/speeches/2014/october/documents/papa-francesco_20141028_incontro-mondiale-movimenti-popolari.html>. Acesso em: 2 ago. 2021.

FRANCISCO. Discurso do Papa Francisco aos participantes no $2^{\circ}$ Encontro Mundial dos Movimentos Populares, 2015b. Disponivel em: <https://www.vatican.va/content/francesco/pt/ speeches/2015/july/documents/papa-francesco_20150709_ bolivia-movimenti-popolari.html>. Acesso em: 2 ago. 2021.

FRANCISCO. Discurso do Papa Francisco aos participantes no $3^{\circ}$ Encontro Mundial dos Movimentos Populares, 2016. Disponível em: <https://www.vatican.va/content/francesco/pt/speeches/2016/november/documents/papa-francesco_20161105_ movimenti-popolari.html>. Acesso em: 2 ago. 2021.

FRANCISCO. Carta do Papa Francisco para o evento "Economy of Francesco", 2019. Disponível em: <https://www.vatican.va/content/francesco/pt/letters/2019/documents/papa-francesco_20190501_giovani-imprenditori.html>. Acesso em: 2 ago. 2021.

FRANCISCO. Encontro Internacional "The Economy of Francesco”. Mensagem em vídeo do Papa Francisco., 202Oa. Disponivel em: <https://www.vatican.va/content/francesco/pt/ messages/pont-messages/2020/documents/papa-francesco_2O2O1121_videomessaggio-economy-of-francesco.html>. Acesso em: 2 ago. 2021 
FRANCISCO. Carta do Papa Francisco aos Movimentos Populares, 2020c. Disponível em: <https://www.vatican.va/content/francesco/pt/letters/2020/documents/papa-francesco_20200412_lettera-movimentipopolari.html>. Acesso em: 2 ago. 2021.

FREIRE, P. Paulo Freire e Marxismo. Disponível em: <https://www.youtube.com/watch?v=Uvdc2YlcZkE>. Acesso em 27/08/2021.

FUNDAÇÃO PERSEU ABRAMO. Percepções e valores políticos nas periferias de São Paulo, 2017. Disponível em: <https://fpabramo.org.br/publicacoes/publicacao/percepcoes-e-valores-politicos-nas-periferias-de-sao-paulo/>. Acesso em: 16 ago. 2021.

GRABOIS, J. Terra, teto e trabalho, 2016. Disponivel em: <http://www.ihu.unisinos.br/78-noticias/558619-terra-teto-e-trabalho-artigo-de-juan-grabois>. Acesso em: 2 ago. 2021.

HANSEN, I. C. Empoderamento feminino é uma questão de consciência. Entrevista com Irmã Cecilia Hansen, 7 mar. 2018. Disponível em: <https://blog.ssps.org.br/empoderamento-feminino-e-uma-questao-de-consciencia-entrevista-com-irma-cecilia-hansen>. Acesso em: 4 ago. 2021.

HECK, S. Na base, pela base, de base, 2019. Disponível em: <https://www.brasildefators.com.br/2019/11/22/na-base-pela-base-de-base>. Acesso em: 19 ago. 2021.

JUCÁ, B. Moradores das favelas sonham com casa e negócio próprios em 2020, mas sem otimismo por segurança, 2019. Disponível em: <https://brasil.elpais.com/ sociedade/2019-12-31/favelas-brasileiras-sonham-com-casa-e-negocio-proprios-para-202O-mas-nao-esperam-mais-seguranca.html>. Acesso em: 17 ago. $2 \mathrm{O} 21$.

MANO BROWN. "Hoje a luta das pessoas é individual. Não vejo mais luta de classes", afirma Mano Brown, 2018. Disponível em: <https://gauchazh.clicrbs.com.br/cultura-e-lazer/ musica/noticia/2018/02/hoje-a-luta-das-pessoas-e-individual-nao-vejo-mais-luta-de-classes-afirma-mano-brown-cjd4ro6d7064kO1kexrlfigt4.html>. Acesso em: 17 ago. 2021.

MICHAELIS. Dicionário online Michaelis. Editora Melhoramentos, 2021. Disponível em: <https://michaelis.uol.com.br/bus$c a$ ? $=0 \& f=0 \& t=O \&$ palavra=alinhavar $>$. Acesso em: 19 ago. 2021.
MOVIMENTO LUTA POPULAR; ASSOCIAÇÃO OCUPAÇÃO JARDIM DA UNIÃO; PEABIRU-TCA. Plano Popular Urbanístico Ocupação Jardim da União, 2017.

PMSP-SMDET. Edital do Programa "Costurando pela Vida" Chamamento público n/O3/2020, 2020. Disponível em: <https://www.prefeitura.sp.gov.br/cidade/secretarias/upload/EditalO1.pdf>. Acesso em: 29 ago. 2021

PONTIFÍCIO CONSELHO JUSTIÇA E PAZ. Compêndio da Doutrina Social da Igreja, 2004. Disponível em: <https://www.vatican. va/roman_curia/pontifical_councils/justpeace/documents/rc_pc justpeace_doc_20060526_compendio-dott-soc_po.html\#Origem\%2Oe\%2Osignificado>. Acesso em: 9 ago. $2 \mathrm{O} 21$.

QUADROS, W. Brasil: um país de classe média?, 2010. Disponível em: <https://diplomatique.org.br/brasil-um-pais-de-classe-media/>. Acesso em: 18 ago. 2021.

RAUPP, K. Aula inicial do curso Repensando Economia com os olhos de Francisco. [Apresentação de apoio à aula lecionada na Faculdade Católica de Santa Catarina], $2 \mathrm{O} 21$.

SILVA, C. DE A. S. et al. Vão, Jovens de Francisco, e reconstruam a nossa economia, que, como veem, cai em ruínas (IHU), 2020. Disponivel em: <http://www.ihu.unisinos.br/78-noticias/603389-vao-jovens-de-francisco-e-reconstruam-a-nossa-economia-que-como-veem-cai-em-ruinas>. Acesso em: 27 ago. 2021

\section{ENTREVISTAS}

MARICATO, Erminia. Entrevista concedida a Claudia de Andrade Silva Duarte. São Paulo, 30 novembro de 2019

PRATES, Peterson Xavier. Entrevista concedida a Claudia de Andrade Silva Duarte. São Paulo, 25 fevereiro de 2020.

HECK, Selvino. Entrevista concedida a Claudia de Andrade Silva Duarte. São Paulo, 16 de junho de 2020.

RODRIGUES, Evaniza Lopes. Entrevista concedida a Camila D’Ottaviano, Claudia Duarte e Renata Antonialli. São Paulo, 05 de fevereiro de 2021 


\section{ANEXO}

\section{Por uma Arquitetura e Urbanismo de libertação $0^{\mathrm{i}}$}

A pesquisa trata de pé e fé na caminhada. E de povo em movimento. Por isso, uma questão que se colocou de fundo foi em relação à minha atuação enquanto arquiteta e urbanista na busca de transformação social e de cidades mais inclusivas, emancipadas e emancipatórias. Pensando nisso, e muito inspirada por todas as reflexões decorrentes do percurso de pesquisa, busco elaborar, mais como devaneio e muito menos com teor conclusivo, o que viria a ser uma Arquitetura e Urbanismo de Libertação. Libertação como contrário de cativeiro,ii e tão expressivamente cantada pelos moradores da ocupação Jardim da União: "levanta povo, cativeiro acabou".

Penso que essa é uma busca muito mais pessoal de alguém que se considera povo e acessou espaços que, pelo curso natural das coisas, "não pertenceriam" à sua classe de origem. E agora, enquanto arquiteta e urbanista, muito se questiona como ocupar esses espaços e não reproduzir tamanha opressão e desigualdade, e, ainda, como superar o caráter elitista que essa profissão carrega. Trago comigo a inquietação de como os territórios populares, muitas vezes, são tratados de maneira tão

Esse texto foi escrito pós banca final, por isso contém parte das discus sões desse momento, no que se refere ao meu olhar enquanto arquiteta e urbanista para a experiência vivida no Jardim da União. Mas principalmente nasceu a partir da provocação e incentivo dado pelo teólogo freiriano Klaus Raupp, que numa das nossas boas conversas indagou: por que você não desenvolve as bases teóricas e praticas de uma Arquitefura e Urbanismo de Libertação? Tendo como base a Teologia da Libertação (de multos autores) e a Pedagogia Critica (principalmente, de Paulo Freire), que propóem a reflexão da fe e a pratica educacional desde a realidade concreta em que pisamos, via processos de dialogo e de estimulo à consciência critica, e a serviço da - BOFF. L. Teologia doc

. 
exógena na academia, ou pior, a carência de tais temas ao longo da minha formação. E, agora, graduada e mestra, o entendimento de que esse campo profissional não deve ser entendido apenas como voluntariado, mas presente em políticas públicas que visem cidades mais democráticas.

A primeira coisa que me vem à mente é que a prática profissional não é exclusivamente técnica, tampouco neutra. E uma prática política e tem lado, cabe saber qual, pois o traço arquitetônico pode tanto reproduzir opressões, como aspirar à transformação social. Inspirada pelo discurso de Che Guevara, no VII Congresso da União Internacional de Arquitetos de Havana (UIA) em Cuba, em (1963), penso na técnica enquanto "arma política", quando ele disse que: "a técnica tem que estar à frente da realidade [...] A técnica é uma arma e cada um a usa como uma arma [...] A técnica pode ser usada para dominar os povos, como também ser usada a serviço dos povos para libertá-los. [...] Para usar a arma da técnica a serviço da sociedade é preciso destruir os fatores de opressão, mudar as condições sociais vigentes em alguns países e entregar aos técnicos de todo tipo, ao povo, a arma da técnica." iii

Nesse sentido, o primeiro ponto é que a Arquitetura e Urbanismo de Libertação tenha como premissa a técnica a partir e a serviço dos empobrecidos. Isso significa o uso da técnica de maneira situada, bem como dialógica e crítica, e em prol de mudanças sociais. A própria foto aérea realizada no Jardim da União (2019), no momento em que a ocupação ainda estava em processo de execução do Plano Popular, é um exemplo da "arma a serviço dos povos", pois se tratou de um instrumento que historicamente está nas mãos de quem detém o poder, mas que ali operou em outra lógica, a favor dos resistentes moradores. Outro exemplo foi o caso da urbanização da favela Brás de Pina (1964), em que o arquiteto Carlos Nelson coloca que os moradores queriam um plano por entendê-lo como instrumento reivindicatório, para discutir com governo de "igual para igual", usando da mesma linguagem e dos seus mesmos fetiches:

Manipular um plano na sociedade urbana atual significa ter muito poder. Se os favelados tivessem o seu plano para antepor aos do governo seriam arrebatados por uma espécie de

iii DORFMAN, Cesar. Havana 63. Porto Alegre: Movimento, 2013, p.106-107. encantamento, que provaria que eles também poderiam pronos privilegiadas iv

Mas, inseridos em uma sociedade extremamente opressora, em um sistema econômico injusto e excludente por natureza, como isso ocorreria? Penso que uma possível resposta encontro em Freire com seu conceito de dialogicidade, pois, segundo ele, a libertação se dá através do diálogo, como também a humanização permanente dos sujeitos. Esse método freireano dialógico problematiza a realidade, de maneira que a libertação requer comunhão, já que "ninguém liberta ninguém, ninguém se liberta sozinho, mas todos se libertam em comunhão”.

Uma prática que dialogue com a luta do povo, respeitando as preexistências e as suas histórias de vida. Compartilho do sentimento de Carlos Nelson, de que, pouco a pouco, sentiu que de arquiteto foi se transformando em um antropólogo, em uma coexistência pacífica e produtiva entre essas duas atuações. A parte antropóloga revertia as tendências homogeneizadoras do planejamento e do projeto, ao reforçar as particularidades. De maneira que passou a observar muito mais as as inter-relações sociais e as redes de significados e, através do contato com os moradores, descobriu "novidades velhas", ou seja, coisas que eram surpreendentes para quem não está inserido naquela realidade, de maneira que, "fui ficando com muita consciência crítica a respeito da minha profissão e do meu grupo profissional. Para agir como arquiteto sobre os meios urbanos brasileiros, era urgente conhecê-los melhor"vi

Por isso, a Arquitetura e Urbanismo de Libertação é necessariamente constituída a partir de um processo participativo, coletivo, pois estar no mundo implica estar com o outro, e na relação com o outro, ambos são afetados. vii Portanto, libertação que não é depositada ou transferida, mas se constrói a partir da práxis, ou seja, ação e reflexão dos oprimidos sobre o mundo que se quer transformar. $\mathrm{O}$ povo em movimento deixa de ser

iv SANTOS, C. N. F. dos. Como e quando pode um arquiteto virar antropólogo?. In: VELHO, G. (org). Rio de Janeiro, Editora Campus, 1980, p.41.

$v$ FREIRE, P. Pedagogia do oprimido. 68. ed. São Paulo: Paz e Terra, 2019 [1968] i SANTOS, C. N. F. dos. Como e quando pode um arquiteto virar antropólogo? In. VELHO G (org). Rio de Janeiro. Editora Campus, 1980, p.43.

vii FREIRE, P. Pedagogia do oprimido. 68. ed. São Paulo: Paz e Terra, 2019 [1968] 
oprimido e de ser visto enquanto objeto e passa a ser sujeito. Portanto, uma atuação que é construída com (e não para) os moradores, enraizada no território, viii já que:

Quem, melhor que os oprimidos, se encontrará preparado para entender o significado terrível de uma sociedade opressora? Quem sentirá, melhor que eles, os efeitos da opressão? Ouem. Quis que thas, par Quna tação? Libertação a que não chegarão pelo acaso, mas pela práxis de sua busca; pelo conhecimento e reconhecimento da necessidade de lutar por ela. Luta que, pela finalidade que the derem os oprimidos, será um ato de amor, com o qual se oporão ao desamor contido na violência dos opressores, até mesmo quando esta se revista de falsa generosidade. . $^{\mathrm{x}}$

Isso significa uma arquitetura que não se refira ao projeto autoral, à genialidade de prancheta, desprendido da realidade, que tem um olhar solar, de cima para baixo, mas o seu contrário, a partir da perspectiva do chão, com pé na realidade, com a longa permanência e com a escuta ativa, afetada, e empática. Esse sim é um possível caminho para a construção de processos emancipatórios e libertários. E, nesse sentido, compartilho também da indagação de Carlos Nelson: como projetar de baixo para cima? ${ }^{x} \mathrm{~A}$ respeito disso, a fala de uma das moradoras do Jardim da União, sobre processo que se dá em comunhão, é extremamente potente:

Cara, imagina se todos os bairros fossem feitos assim, pensado por quem mora lá sabe? Que top que seria isso? Se todo bairro tivesse alguém que chega, troca ideia com o morador

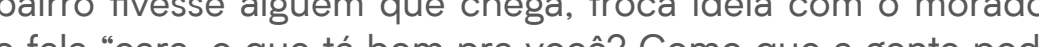
fazer isso a que tá bom pra voce? Como que a gente pode fazer isso aqui melhorar? "Eu acho que esse e o correto, na verdade, né? Mas na verdade, tudo que é feito na periferia feito por quem não mora na periferia, não entende o que que acontece aqui dentro, não sabe de nada, a logística ridícula pra gente em relação ao transporte público. Porque assim, foi feito por quem não tem a menor ideia do que acontece aqui.

Viii D'OTTAVIANO, C. Extensão em Movimento. In: D'OTTAVIANO, C. (org.) ROVATT, J. (org). Altém dos Muros da Univensi regional e extensão universitária. São Paulo: FAUUSP/ANPUR, 2019.

ix FREIRE. P. Pedagogia do oprimido. 68. ed. São Paulo: Paz e Terra, 2019 [1968].

$x$ Santos, C. N. F. Como projetar de baixo para cima - uma experiência em favela. Revista de Administração Municipal, Rio de Janeiro, ano 27. n. 156 p.627, 1980 .

xi Informação verbal, CPPATHIS, 2019.
Penso que é uma prática que requer muito mais processo do que projeto, já que, sabidamente, esse não dá conta das dinâmicas e complexidades. Processo repleto de idas e vindas e do improviso. O projeto poderia cumprir um papel político de negociação com poder público, de instrumento de resistência e de diálogo com todos os envolvidos na elaboração dele. Por isso, é possível dizer que se trata de práticas políticas, como bem define Ferreira:

São políticas no sentido em que o indivíduo ou um grupo é dotado de intenção de carácter social, e que pretende transformar a sociedade como ela está colocada. São políticas sem pretenderem ser partidárias, e muitas vezes são políticas sem aspirarem a sê-lo conscientemente. Por serem políticas, transformam o indivíduo dotado de intenção em sujeito xii

Mas, para isso, está lançado um grande desafio: a linguagem. É necessário (e urgente) pensar em novas ferramentas, métodos e representações, tanto na formação, quanto na atuação desses profissionais comprometidos com a realidade. Penso que essa discussão tem relação com a crítica que Ferro (2021) xiii $^{\text {in }}$ faz ao desenho funcionalizado, submetido, burocratizado, separado do contexto da produção e de seus produtores, que nasce com a destruição da autonomia do canteiro. Concordo com Ferro (2021), quando diz que é preciso a reinvenção de um desenho situado, comprometido e imerso à realidade. Um desenho integrado com o momento da produção é o oposto do desenho escravizador a serviço do capital.

Hoje, o desenho está fortemente relacionado ao Capital, que traz soluções totalizantes e generalistas à cidade-mercadoria, no qual os saberes não se colocam lado a lado, mas fortemente hierarquizados. Aqui, propõe-se o inverso: que o saber/fazer popular importa tanto quanto o dito científico; "trata-se, portanto, de processo compartilhado, do lugar da prática social, que pretende desfazer qualquer hierarquia existente entre os xii FERREIRA, L. I. C. Intervenção em Favelas como Prática Politica Militante.
In: FERREIRA, L.; OLIVEIRA, P.; IACOVINI, V. (Orgs). Dimensões do Intervir em Favelas: desafios e perspectivas São Paulo: Peabiru TCA e Coletivo Lablaje: 2019, p.205. 2021. 
saberes científicos e não científicos." xiv Propõe-se, também, a transição de um desenho separado para um emancipatório, o retorno da arquitetura ao canteiro, a partir de processos horizontalizados e autogeridos por todos envolvidos.

Assim, enquanto processo acadêmico, faz-se necessário: uma epistemologia indutiva, que parte dos oprimidos e interpela mutuamente o chão da realidade e a técnica; uma abordagem científica histórica, que não separe o conhecimento produzido e aplicado dos espaços reais onde a vida humana e social se realiza (pelo contrário, que os integre); uma construção "ascendente", que, antes, esteja atenta ao "ver" (que compreenda adequadamente, via mediações sócio-análiticas, as opressões impostas pelo modo capitalista de produção), e que, nessa metodologia dialética, oriente-se ao "julgar" (que interprete/analise, honestamente e a partir de bases humanísticas, a realidade observada) dirija-se praxiologicamente ao agir (que desenvolva/construa os saberes necessários à transformação enquanto práxis - prática refletida); a dizer, uma arquitetura e urbanismo da libertação. ${ }^{x v}$

Creio que o trabalho coletivo cria solidariedade, sendo a solidariedade entendida não como gesto esporádico, mas como possibilidade revolucionária, como potência transformadora. Como expressou Paulo Freire em seu último livro publicado em vida, parto de uma fé que se constitui como "impulso deflagrador da rebeldia amorosa, necessária à transformação do mundo". xvi Nesse sentido, ouso dizer, também, que a temática do afeto passa pela definição do que seria essa arquitetura $e$ urbanismo, nos termos de Federici:
'Afeto' não significa um sentimento de ternura ou amor. Significa, antes, nossa capacidade de interação, nossa capacidade de movimento e de sermos movidos em um fluxo interminável de movimento e de sermos movidos em um fuxo interminável de trocas e encontros, que supostam poderes e demonstram não apenas a infinita produtividade de nosso ser, mas também o caráter transformador - e, portanto, já político - da vida cotidiana. xvii

Para além da prática que resulta na construção de espaços, trata-se da construção de pessoas, sobretudo de nós, num eterno aprender enquanto atuamos. xviii Precisamos aprender a aprender, pois "quando você aprende a se examinar criticamente, vê tudo ao seu redor com um novo olhar". xix

Reconhecendo os limites e contradições dessa atuação, contudo, a Arquitetura e Urbanismo de Libertação é aqui entendida como uma prática possível, uma vez inserida nas condições estruturais que organizam a sociedade. Até mesmo os $\mathrm{Pla}-$ nos Populares, trazidos aqui como um possível exemplo dessa prática, são um resultado das condições objetivas e impostas, pois, como disse uma moradora do Jardim da União, "lá fora tem o capitalismo arregaçando", impondo limites e bloqueios para a real democratização das cidades. Mas, motivo-me a escrever este texto com entusiasmo, pois ficar apenas na crítica ou na aceitação das imposições desse sistema nos impede de sonhar e de ter fé em outros mundos possíveis, e de acreditar em uma Arquitetura e Urbanismo de Libertação que promova uma sociedade na qual o acesso à cidade seja direito de todas as pessoas. xiv MORADO NASCIMENTO, D. O Que É Extensão? incertezas e provações

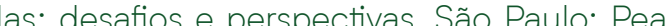
2019, p.242.

xV Cf. BOFF, L. \& BOFF, C., Como fazer teologia da libertação. 3ed. Petrópolis: Vozes 1986, pp. 39-63. cf. Idem Teologia da libertacão no debete atud. 3 ed. Petrópolis: Vozes, 1985, pp. 20-25.

xvi FREIRE, À sombra desta mangueira, 12 ed. Rio de Janeiro / São Paulo: Paz e Terra, 2019, p. 148. xvii FEDERICl, S. O ponto zero da revolução: trabalho doméstico, reprodução e luta feminista. Tradução de Coletivo Sycorax. São Paulo: Elefante, 2019, 338

xviii Fala da professora Dra. Karina Leitão na aula 3, "Matrizes de Assessoria", do curso OCUPATHIS, FAU-USP, em 11 mai. 2021.

xix HOOKS, B. Ensinando a transgredir: a educação como prática da liberdade. Traducão de Marcelo Brandão Cipolla. 2. ed. São Paulo: Editora WMF 



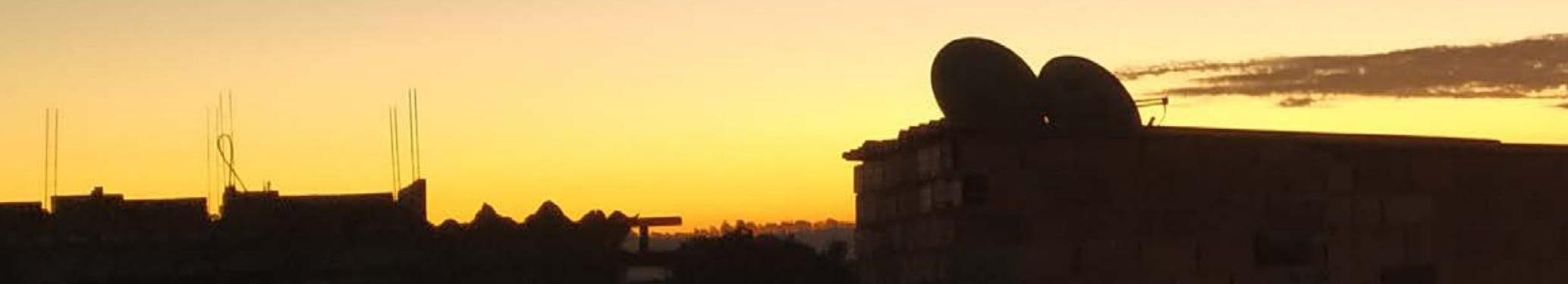

$\sum_{2 m}^{M M 4 / 4}$ FAUUSP 